\title{
Hanford Site Environmental Management Specification
} United States
Department of Energy
Richland, Washington 
LEGAL DISCLAIMER

This report was prepared as an account of work sponsored by an agency of the United States Government. Neither the United States Government nor any agency thereof, nor any of their employees, nor eny of their contractors, subcontractors or their employees, makes any warranty, express or implied, or assumes any legal liability or responsibility for the accuracy, completeness, or any third party's use or the results of such use of any information, apparatus, product, or process disclosed, or represents that its use would not infringe privately owned rights. Reference herein to any specific commercial product, process, or service by trade name, trademark, manufacturer, or otherwise, does not necessarily constitute or imply its endorsement, recommendation, or favoring by the United States Government or any agency thereof or its contractors or subcontractors. The views and opinions of authors expressed herein do not necessarily state or reflect those of the United States Government or any agency thereof.

This report has been reproduced from the best available copy.

Printed in the United States of America

DISCLM-2.CHP (1-91) 


\section{Hanford Site Environmental Management Specification}




\section{RELEASE AUTHORIZATION}

Document Number: $\quad \mathrm{DOE} / \mathrm{RL}-97-55$

Document Title:

Hanford Site Environmental Management Specification

This document, reviewed in accordance with DOE Order 1430.1D, "Scientific and Technical Information Management;" and DOE G 1430.1D-1, "Guide to the Management of Scientific and Technical Information," does not contain classified or sensitive unclassified information and is:

\section{APPROVED FOR PUBLIC RELEASE}

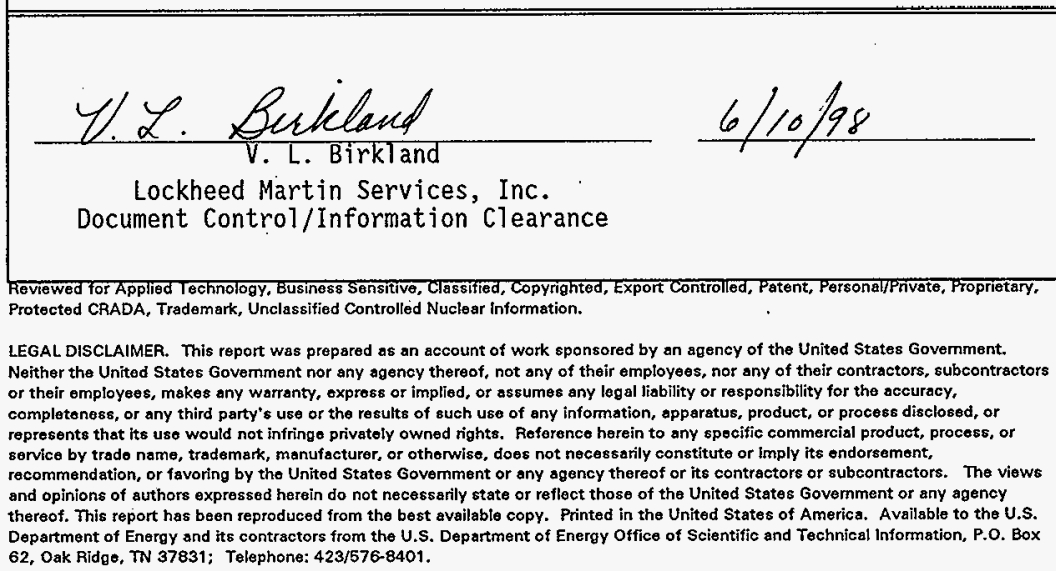

Avallable to the public from the U.S. Department of Commerce Nationa! Technicel Information Service, 5285 Port Royal Road, Springfield, VA 22161; Telephone: 703/487-4650. 
DOE/RL-97-55

Revision 0

\section{HANFORD SITE ENVIRONMENTAL MANAGEMENT SPECIFICATION}

Approved by: Approved at Site Management Board

Date:

meeting on December 8, 1997

Lloyd Piper, Deputy Manager

U.S. Department of Energy,

Richland Operations Office 
DOE/RL-97-55

Revision 0

This page intentionally left blank. 
DOE/RL-97-55

Revision 0

\section{CONTENTS}

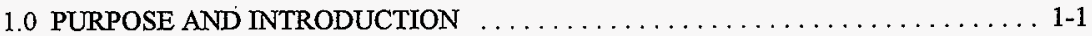

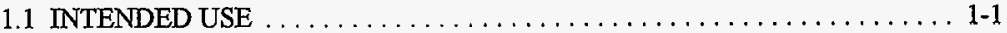

1.2 RELATIONSHEP TO OTHER DOCUMENTS AND PROCESSES $\ldots \ldots \ldots \ldots 1-1$

1.2.1 Tribal, Regulatory, and Public Involvement in Decision Making ..... 1-1

1.2.2 Decision-Related Actions $\ldots \ldots \ldots \ldots \ldots \ldots \ldots \ldots \ldots \ldots \ldots$

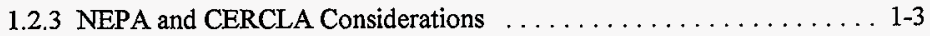

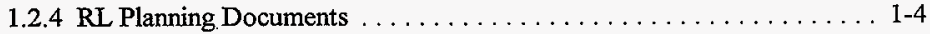

1.3 AUTHORITY .................................... 1.4

1.4 REQUIREMENTS AND PLANNING ASSUMPTIONS $\ldots \ldots \ldots \ldots \ldots \ldots 1.4$

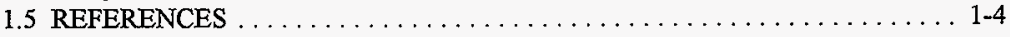

2.0 HANFORD SITE ENVIRONMENTAL MANAGEMENT MISSION AND SITE

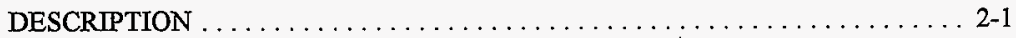

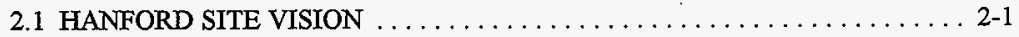

2.2 HANFORD SITE ENVIRONMENTAI MANAGEMENT MISSIONS $\ldots \ldots .2-1$

2.3 GEOGRAPHIC AREAS, REQUIREMENTS, AND PLANNING

ASSUMPTIONS ............................. 2-1

2.4 MATERIAL CATEGORIES, REQUIREMENTS, AND PLANNING

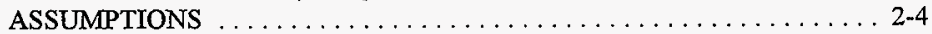

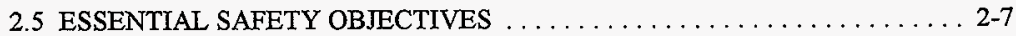

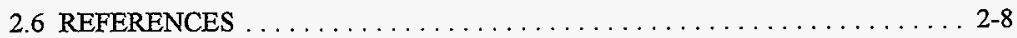

3.0 SITE REQUIREMENTS AND PLANNING ASSUMPTIONS $\ldots \ldots \ldots \ldots \ldots \ldots .3-1$

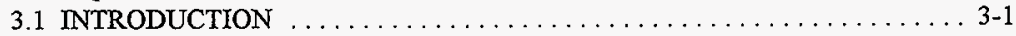

3.2 INTERFACES . . . . . . . . . . . . . . . . .

3.2.1 Site-Level Material and Waste Flow Interfaces . . . . . . . . . . 3-1

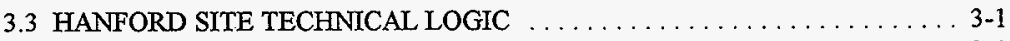

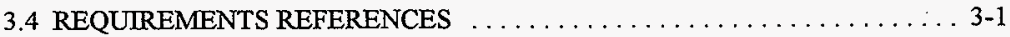

3.5 MAJOR CONTRACTOR WORK SCOPE $\ldots \ldots \ldots \ldots \ldots \ldots \ldots \ldots \ldots .3-12$

3.5.1 Fluor Daniel Hanford, Inc., Contract Requirements Summary . . . . . . 3-13

3.5.1.1 Waste Minimization ................... 3-14

3.5.1.2 Management and Execution of Cleanup Mission. . . . . . . 3-14

3.5.2 Battelle Memorial Institute Contract Requirements Summary ....... 3-14

3.5.2.1 Operating and Management Services - Statement of Work Summary ........................ 3-14

3.5.2.2 Related Services . . . . . . . . . . . . . . . . 3-15

3.5.2.3 General ........................... 3-16

3.5.2.4 Special Contract Requirements .............. 3-16

3.5.3 Bechtel Hanford, Inc., Contract Requirements Summary . . . . . . . . 3-18

3.5.4 Tank Waste Remediation System Privatization Contract Requirements

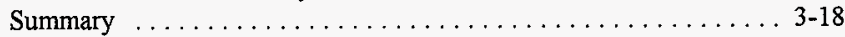

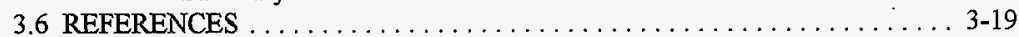

3.7 BIBLIOGRAPHY $\ldots \ldots \ldots \ldots \ldots \ldots \ldots \ldots \ldots \ldots \ldots \ldots \ldots \ldots \ldots \ldots \ldots, 22$ 
DOE/RL-97-55

Revision 0

CONTENTS (cont)

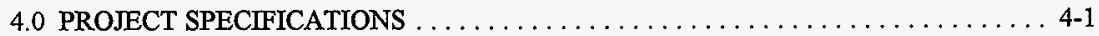

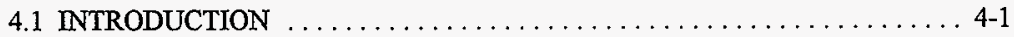

4.2 FDH CONTRACT REQUIREMENTS $\ldots \ldots \ldots \ldots \ldots \ldots \ldots \ldots \ldots \ldots$ 4-1

4.2.1 TWRS Summary Description .................. 4-3

4.2.1.1 Tank Waste Characterization Project ........... 4-3

4.2.1.1.1 Project Description Summary ............. 4-3

4.2.1.1.2 Geographic Requirements/Assumptions . . . . . . 4 4-7

4.2.1.1.3 Material and Waste Flow Requirements/

Assumptions . .................. 4-7

4.2.1.1.4 Facility Life-Cycle Requirements/Assumptions .... 4-7

4.2.1.1.5 Project Safety Authorization Basis/NEPA and

Permits .................... 4-8

4.2.1.1.6 Other Requirements and Planning Assumptions,

Including DNFSB $\ldots \ldots \ldots \ldots \ldots \ldots \ldots \ldots, 4-8$

4.2.1.1.7 Interfaces . . . . . . . . . . . . . . . . . . . . . . . . 4-9

4.2.1.1.8 Logic Diagram . . . . . . . . . . . . . . . . . . . . 4 4-9

4.2.1.1.9 Requirements References . . . . . . . . . . . . 4-9

4.2.1.2 Tank Safety Issue Resolution Project . . . . . . . . . . . 4-11

4.2.1.2.1 Project Description Summary . . . . . . . . . 4-11

4.2.1.2.2 Geographic Requirements/Assumptions ....... 4-12

4.2.1.2.3 Material and Waste Flow Requirements/

Assumptions ................. 4-12

4.2.1.2.4 Facility Life-Cycle Requirements/Assumptions . . . 4 4-12

4.2.1.2.5 Project Safety Authorization Basis/NEPA and Permits . . . . . . . . . . . . . . . . . 4-13

4.2.1.2.6 Other Requirements and Planning Assumptions, Including DNFSB $\ldots \ldots \ldots \ldots \ldots \ldots \ldots \ldots 4-13$

4.2.1.2.7 Interfaces . . . . . . . . . . . . . . . . . . . . . . . 4 4-14

4.2.1.2.8 Logic Diagram . . . . . . . . . . . . . . . . . 4-15

4.2.1.2.9 Requirements References . . . . . . . . . . 4-15

4.2.1.3 Tank Farm Operations Project ............... 4-15

4.2.1.3.1 Project Description Summary ............ 4-15

4.2.1.3.2 Geographic Requirements/Assumptions . . . . . . 4 4-16

4.2.1.3.3 Material and Waste Flow Requirements/
Assumptions ................... 4-16

4.2.1.3.4 Facility Life-Cycle Requirements/Assumptions . . . 4-16

4.2.1.3.5 Project Safety Authorization Basis/NEPA and Permits ....................... 4-17

4.2.1.3.6 Other Requirements and Planning Assumptions, Including DNFSB $\ldots \ldots \ldots \ldots \ldots \ldots \ldots, 4-17$

4.2.1.3.7 Interfaces . . . . . . . . . . . . . . . . . 4-19

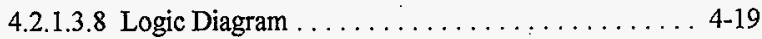

4.2.1.3.9 Requirements References ............. 4-19 
DOE/RL-97-55

Revision 0

CONTENTS (cont)

4.2.1.4 Retrieval Project . . . . . . . . . . . . . . . 4-21

4.2.1.4.1 Project Description Summary ............ 4-21

4.2.1.4.2 Geographic Requirements/Assumptions ...... 4-22

4.2.1.4.3 Material and Waste Flow Requirements/ Assumptions . . . . . . . . . . 22

4.2.1.4.4 Facility Life-Cycle Requirements/Assumptions . . . 4-23

4.2.1.4.5 Project Safety Authorization Basis/NEPA and Permits ..................... 4-24

4.2.1.4.6 Other Requirements and Planning Assumptions, Including DNFSB . . . . . . . . . . . . 4 4 4 .25

4.2.1.4.7 Interfaces . . . . . . . . . . . . . . . . . 4-26

4.2.1.4.8 Logic Diagram . . . . . . . . . . . . . . . 4-27

4.2.1.4.9 Requirements References . . . . . . . . . . 4 4-27

4.2.1.5 Process Waste Support Project . . . . . . . . . . . . . 4-28

4.2.1.5.1 Project Description Summary ............ 4-28

4.2.1.5.2 Geographic Requirements/Assumptions . . . . . . 4 4-29

4.2.1.5.3 Material and Waste Flow Requirements/ Assumptions . . . . . . . . . . . . . . 4-29

4.2.1.5.4 Facility Life-Cycle Requirements/Assumptions . . . 4-29

4.2.1.5.5 Project Safety Authorization Basis/NEPA and Permits . . . . . . . . . . . . . . . . . 4 4-29

4.2.1.5.6 Other Requirements and Planning Assumptions, Including DNFSB $\ldots \ldots \ldots \ldots \ldots \ldots \ldots . \ldots \ldots$

4.2.1.5.7 Interfaces . . . . . . . . . . . . . . . 4 4 41

4.2.1.5.8 Logic Diagram . . . . . . . . . . . . . . 4-31

4.2.1.5.9 Requirements References ............. 4-31

4.2.1.6 Privatization Phase I Project . . . . . . . . . . . . 4 .31

4.2.1.7 Privatization Phase II Project ................ 4-31

4.2.1.8 Privatization Infrastructure Project . . . . . . . . . 4-31

4.2.1.8.1 Project Description Summary ............ . 4-31

4.2.1.8.2 Geographic Requirements/Assumptions ...... 4-32

4.2.1.8.3 Material and Waste Flow Requirements/ Assumptions .................. 4-32

4.2.1.8.4 Facility Life-Cycle Requirements/Assumptions ... 4 4-33

4.2.1.8.5 Project Safety Authorization Basis/NEPA and Permits ................... 4.33

4.2.1.8.6 Other Requirements and Planning Assumptions, Including DNFSB $\ldots \ldots \ldots \ldots \ldots \ldots \ldots \ldots 4.33$

4.2.1.8.7 Interfaces . . . . . . . . . . . . . . . . . 4 4-34

4.2.1.8.8 Logic Diagram . . . . . . . . . . . . . . 4-35

4.2.1.8.9 Requirements References ............. 4-35

4.2.1.9 Immobilized Tank Waste Storage \& Disposal Project . . . . 4 4-36

4.2.1.9.1 Project Description Summary . . . . . . . . . 4 4 47 
DOE/RL-97-55

Revision 0

\section{CONTENTS (cont)}

4.2.1.9.2 Geographic Requirements/Assumptions

4.2.1.9.3 Material and Waste Flow Requirements/

4.2.1.9.4 Facility Life-Cycle Requirements/Assumptions ... . 4-38

4.2.1.9.5 Project Safety Authorization Basis/NEPA and

Permits

4.2.1.9.6 Other Requirements and Planning Assumptions, Including DNFSB $\ldots \ldots \ldots \ldots \ldots \ldots \ldots, 4-40$

4.2.1.9.7 Interfaces . . . . . . . . . . . . . . . . . . . . 4-41

4.2.1.9.8 Logic Diagram . . . . . . . . . . . . . . . . 4-41

4.2.1.9.9 Requirements References ................ 4-42

4.2.1.10 TWRS Management Support Project ........... 4-43

4.2.1.10.1 Project Description Summary . . . . . . . . . . . . 4-43

4.2.1.10.2 Geographic Requirements/Assumptions ... . . . 4 4-43

4.2.1.10.3 Material and Waste Flow Requirements/

Assumptions . . . . . . . . . . . . . 4-44

4.2.1.10.4 Facility Life-Cycle Requirements/Assumptions . . 4-44

4.2.1.10.5 Project Safety Authorization Basis/NEPA and Permits ..................... 4-44

4.2.1.10.6 Other Requirements and Planning Assumptions, Including DNFSB . . . . . . . . . . . . . . 4-44

4.2.1.10.7 Interfaces . . . . . . . . . . . . . . . . . 4-44

4.2.1.10.8 Logic Diagram . . . . . . . . . . . . . . . . . 4-45

4.2.1.10.9 Requirements References ............ . 4-45

4.2.2 Waste Management Project . . . . . . . . . . . . . . . . 4-47

4.2.2.1 Solid Waste . . . . . . . . . . . . . . . . . . . . 4-47

4.2.2.1.1 Project Description Summary . . . . . . . . . . . 4 4-47

4.2.2.1.2 Geographic Requirements/Assumptions . . . . . . 4 4-48

4.2.2.1.3 Material and Waste Flow Requirements/

Assumptions . . . . . . . . . . . . . . . 4 4-48

4,2.2.1.4 Facility Life-Cycle Requirements/Assumptions . . . 4 4-49

4.2.2.1.5 Key Technical Requirements ........... 4-50

4.2.2.1.6 Project Safety Authorization Basis/NEPA and

Permits ....................... 4-59

4.2.2.1.7 Other Requirements and Planning Assumptions . . 4 4-60

4.2.2.1.8 Interfaces . . . . . . . . . . . . . . . . . . 4-60

4.2.2.1.9 Logic Diagram . . . . . . . . . . . . . . 4-61

4.2.2.1.10 Requirements References . . . . . . . . . . 4-61

4.2.2.1.11 Planning Assumptions $\ldots \ldots \ldots \ldots \ldots \ldots$ 4-61

4.2.2.2 Liquid Waste Program . . . . . . . . . . . . . . . . 4-61

4.2.2.2.1 Project Description Summary . . . . . . . . . . . 4-61

4.2.2.2.2 Geographic Requirements/Assumptions . . . . . 4 4-62 


\section{DOE/RL-97-55 \\ Revision 0 \\ CONTENTS (cont)}

4.2.2.2.3 Material and Waste Flow Requirements/ Assumptions .................... 4-64

4.2.2.2.4 Facility Life-Cycle Requirements/Assumptions ... 4 4-65

4.2.2.2.5 Project Safety Authorization Basis/NEPA and Permits ........................ 4-67

4.2.2.2.6 Other Requirements and Planning Assumptions . . 4 4-68

4.2.2.2.7 Interfaces . . . . . . . . . . . . . . . . . . . 4-70

4.2.2.2.8 Logic Diagram . . . . . . . . . . . . . . 4 4-71

4.2.2.2.9 Requirements References . . . . . . . . . . . . . . 4 4-71

4.2.2.2.10 Planning Assumptions $\ldots \ldots \ldots \ldots \ldots \ldots$ 4-73

4.2.2.3 Analytical Services . . . . . . . . . . . . . . . . . 4-73

4.2.2.3.1 Project Description Summary . . . . . . . . . . 4 4-73

4.2.2.3.2 Geographic Requirements/Assumptions . . . . . . 4.74

4.2.2.3.3 Material and Waste Flow Requirements/

Assumptions . . . . . . . . . . . . . . . . 4-75

4.2.2.3.4 Facility Life-Cycle Requirements/Assumptions ... 4 4-76

4.2.2.3.5 Project Safety Authorization Basis/NEPA and

Permits ..................... 4-76

4.2.2.3.6 Other Requirements and Planning Assumptions . . 4 4-77

4.2.2.3.7 Interfaces . . . . . . . . . . . . . . . . . . . . . 4 4-77

4.2.2.3.8 Logic Diagram . . . . . . . . . . . . . . . . . 4 4-78

4.2.2.3.9 Requirements References . . . . . . . . . . . 4 4-78

4.2.2.3.10 Planning Assumptions $\ldots \ldots \ldots \ldots \ldots \ldots$ 4-78

4.2.3 SNF Project ............................. 4-80

4.2.3.1 Project Description Summary . . . . . . . . . . . . . 4-80

4.2.3.2 Geographic Requirements/Assumptions ......... 4-80

4.2.3.3 Material and Waste Flow Requirements/Assumptions . . . . 4 4-81

4.2.3.4 Facility Life-Cycle Requirements/Assumptions . . . . . . . . 4-82

4.2.3.5 Key Technical Requirements . . . . . . . . . . . . 4-83

4.2.3.5.1 $100 \mathrm{~K}$ Area Facilities . . . . . . . . . . . . . . . 4-83

4.2 .3 .5 .2 CSB . . . . . . . . . . . . . . . . 4-84

4.2.3.5.3 200 Area ISA . . . . . . . . . . . . . 4.85

4.2.3.6 Project Safety Authorization Basis/NEPA and Permits . . . . 4-86

4.2.3.7 Other Requirements and Planning Assumptions . . . . . . 4-87

4.2.3.8 Interfaces . . . . . . . . . . . . . . . . . . . . . . 4 488

4.2.3.9 Logic Diagram . . . . . . . . . . . . . . . . . . . . . 4-88

4.2.3.10 Other Requirements References . . . . . . . . . . . 4-88

4.2.3.11 Other Planning Assumptions . . . . . . . . . . . . . 4-90

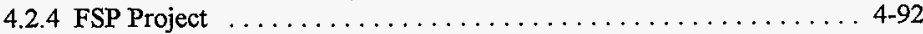

4.2.4.1 Project Description Summary . . . . . . . . . . . . . . . . . 4-93

4.2.4.1.1 Project Overview . . . . . . . . . . . . . 4-93

4.2.4.1.2 Geographic Requirements/Assumptions . . . . . . 4-96 
DOE/RL-97-55

Revision 0

\section{CONTENTS (cont)}

4.2.4.1.3 Material and Waste Flow Requirements/ Assumptions . . . . . . . . . . . . . . . 4-96

4.2.4.1.4 Facility Life-Cycle Requirements/Assumptions . . . 4 4-96

4.2.4.1.5 Project Safety Authorization Basis . . . . . . . . . 4-97

4.2.4.1.6 Other Requirements and Planning Assumptions . . 4 4-97

4.2.4.1.7 Interfaces . . . . . . . . . . . . . . . . . . . 4 4-97

4.2.4.1.8 Logic Diagram . . . . . . . . . . . . . . . . . 4-98

4.2.4.1.9 Requirements References . . . . . . . . . . . . 4 4-98

4.2.4.1.10 Issues . . . . . . . . . . . . . . . . . . . 4-100

4.2.4.2 B Plant Subproject .................... 4-101

4.2.4.2.1 Project Description Summary . . . . . . . . . . 4-101

4.2.4.2.2 Geographic Requirements/Assumptions . . . . . . 4-102

4.2.4.2.3 Material and Waste Flow Requirements/

Assumptions ................. 4-102

4.2.4.2.4 Facility Life-Cycle Requirements/Assumptions . . 4 4-103

4.2.4.2.5 Project Safety Authorization Basis . . . . . . . . 4 4-103

4.2.4.2.6 Other Requirements and Planning Assumptions .. 4-103

4.2.4.2.7 Interfaces . . . . . . . . . . . . . . . . . . 4-105

4.2.4.2.8 Requirements References . . . . . . . . . . 4-105

4.2.4.2.9 Issues . . . . . . . . . . . . . . . 4-105

4.2.4.3 WESF Subproject $\ldots \ldots \ldots \ldots \ldots \ldots \ldots \ldots \ldots \ldots$ 4-106

4.2.4.3.1 Project Description Summary . . . . . . . . . . . 4-106

4.2.4.3.2 Geographic Requirements/Assumptions ... . . . 4-106

4.2.4.3.3 Material and Waste Flow Requirements/

Assumptions .................. 4-107

4.2.4.3.4 Facility Life-Cycle Requirements/Assumptions . . . 4-107

4.2.4.3.5 Project Safety Authorization Basis . . . . . . . . 4 4-108

4.2.4.3.6 Other Requirements and Planning Assumptions .. 4-108

4.2.4.3.7 Interfaces . . . . . . . . . . . . . . . . . . 4-108

4.2.4.3.8 Requirements References ..... . . . . . . . . . 4 4-109

4.2.4.3.9 Issues . . . . . . . . . . . . . . . . . . . . 4-109

4.2.4.4300 Area/SNM Subproject . . . . . . . . . . . . . . . 4-109

4.2.4.4.1 Project Description Summary . . . . . . . . . . . 4-109

4.2.4.4.2 Geographic Requirements/Assumptions ...... 4-110

4.2.4.4.3 Material and Waste Flow Requirements/

Assumptions .................. 4-111

4.2.4.4.4 Facility Life-Cycle Requirements/Assumptions . . 4-111

4.2.4.4.5 Project Safety Authorization Basis . . . . . . . 4 4-112

4.2.4.4.6 Other Requirements and Planning Assumptions . . 4-112

4.2.4.4.7 Interfaces . . . . . . . . . . . . . . . . . 4-112

4.2.4.4.8 Requirements References ............. 4-113

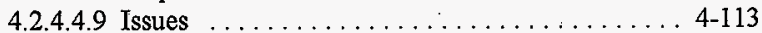

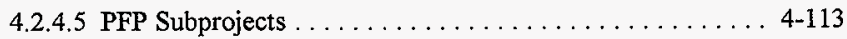


DOE/RL-97-55

Revision 0

CONTENTS (cont)

4.2.4.5.1 Project Description Summary ............ 4-113

4.2.4.5.2 Project Safety Authorization Basis .......... 4-114

4.2.4.5.3 Other Requirements and Planning Assumptions .. 4-114

4.2.4.6 PFP Deactivation .................... 4-115

4.2.4.6.1 Project Description Summary ........... . 4-115

4.2.4.6.2 Geographic Requirements/Assumptions ...... 4-116

4.2.4.6.3 Material and Waste Flow Requirements/ Assumptions . . . . . . . . . . . 118

4.2.4.6.4 Facility Life-Cycle Requirements/Assumptions . . . 4-118

4.2.4.6.5 Other Requirements and Planning Assumptions .. 4-119

4.2.4.6.6 Interfaces .................... 4-120

4.2.4.6.7 Requirements References .............. . 4-121

4.2.4.6.8 Issues . . . . . . . . . . . . . . . . . . . . 4-121

4.2.4.7 PFP Stabilization ....................... 4-122

4.2.4.7.1 Project Description Summary . . . . . . . . . . . . 4-122

4.2.4.7.2 Geographic Requirements/Assumptions . . . . . . 4-123

4.2.4.7.3 Material and Waste Flow Requirements/

Assumptions ................. 4-124

4.2.4.7.4 Facility Life-Cycle Requirements/Assumptions . . . 4-124

4.2.4.7.5 Other Requirements and Planning Assumptions . . 4-124

4.2.4.7.6 Interfaces ..................... . 4-126

4.2.4.7.7 Requirements References . . . . . . . . . . . . . 4-127

4.2.4.7.8 Issues . . . . . . . . . . . . . . . . . . 4-127

4.2.4.8 PFP Vault Management .................. 4-128

4.2.4.8.1 Project Description Summary . . . . . . . . . . . 4-128

4.2.4.8.2 Geographic Requirements/Assumptions . . . . . . 4-129

4.2.4.8.3 Material and Waste Flow Requirements/

Assumptions . ................ 4-130

4.2.4.8.4 Facility Life-Cycle Requirements/Assumptions . . 4-131

4.2.4.8.5 Other Requirements and Planning Assumptions .. 4-131

4.2.4.8.6 Interfaces . . . . . . . . . . . . . . . . . 4-133

4.2.4.8.7 Requirements References ............. 4-134

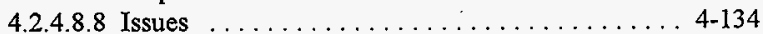

4.2.4.9 324/327 Facility Transition Project . . . . . . . . . . 4-135

4.2.4.9.1 Project Description Summary ............ 4-135

4.2.4.9.2 Geographic Requirements/Assumptions ..... . 4-136

4.2.4.9.3 Material and Waste Flow Requirements/

Assumptions ................... 4-137

4.2.4.9.4 Facility Life-Cycle Requirements/Assumptions . . 4-138

4.2.4.9.5 Project Safety Authorization Basis . . . . . . . . . 4-138

4.2.4.9.6 Other Requirements and Planning Assumptions .. 4-139

4.2.4.9.7 Interfaces . . . . . . . . . . . . . . . . . . . . . . . . . . 4-139

4.2.4.9.8 Requirements References ............. 4-140 
DOE/RL-97-55

Revision 0

CONTENTS (cont)

4.2.4.9.9 Issues . . . . . . . . . . . . . . . . 4-140

4.2.4.10 Accelerated Deactivation Project . . . . . . . . . . . 4-140

4.2.4.10.1 Project Description Summary ........... 4-140

4.2.4.10.2 Geographic Requirements/Assumptions ...... 4-141

4.2.4.10.3 Material and Waste Flow Requirements/

Assumptions . . . . . . . . . . . . 4 4-142

4.2.4.10.4 Facility Life-Cycle Requirements/Assumptions . . 4-142

4.2.4.10.5 Project Safety Authorization Basis ......... 4-142

4.2.4.10.6 Other Requirements and Planning Assumptions . 4-142

4.2.4.10.7 Interfaces . . . . . . . . . . . . . . . . 4 4-143

4.2.4.10.8 Logic Diagram ................... . 4-144

4.2.4.10.9 Requirements References . . . . . . . . . . . 4-144

4.2.4.10.10 Issues . . . . . . . . . . . . . . . . . . 4-144

4.2.4.11 300 Area Disposition Project . . . . . . . . . . . . 4-144

4.2.4.11.1 Project Description Summary ............. 4-144

4.2.4.11.2 Geographic Requirements/Assumptions ... . . . 4-146

4.2.4.11.3 Material and Waste Flow Requirements/

Assumptions ................ 4-146

4.2.4.11.4 Facility Life-Cycle Requirements/Assumptions . . 4-147

4.2.4.11.5 Project Safety Authorization Basis/NEPA and

Permits ..................... 4-147

4.2.4.11.6 Other Requirements and Planning Assumptions . 4-147

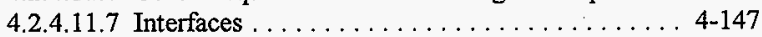

4.2.4.11.8 Requirements References . . . . . . . . . . . 4-148

4.2.4.11.9 Issues . . . . . . . . . . . . . . . . . . . . . . . 4 4-148

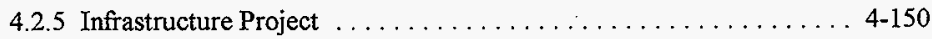

4.2.5.1 Landlord Project .................. 4-150

4.2.5.1.1 Project Description Summary . . . . . . . . . . 4 4-150

4.2.5.1.2 Geographic Requirements/Assumptions ..... . 4-150

4.2.5.1.3 Material and Waste Flow Requirements/

Assumptions .................. 4-151

4.2.5.1.4 Facility Life-Cycle Requirements/Assumptions . . . 4-151

4.2.5.1.5 Key Technical Requirements .......... 4-152

4.2.5.1.6 Project Safety Authorization Basis/NEPA and

Permits ..................... 4-153

4.2.5.1.7 Other Requirements and Planning Assumptions,

Including DNFSB $\ldots \ldots \ldots \ldots \ldots \ldots \ldots 4-153$

4.2.5.1.8 Interfaces . . . . . . . . . . . . . . . . . 4-153

4.2.5.1.9 Logic Diagram . . . . . . . . . . . . . . . . . . . 4-154

4.2.5.1.10 Requirements References ............. 4-154

4.2.5.1.11 Additional Planning Assumptions ... . . . . . . 4-154

4.2.5.2 Infrastructure Project, Including Utilities, Roads and Grounds,

Buildings, and Maintenance of Same, and Railroad . . . . . 4-154 
DOE/RL-97-55

Revision 0

\section{CONTENTS (cont)}

4.2.5.2.1 Project Description Summary ............ 4-154

4.2.5.2.2 Geographic Requirements/Assumptions .... . . 4-155

4.2.5.2.3 Material and Waste Flow Requirements/ Assumptions .................. 4-155

4.2.5.2.4 Facility Life-Cycle Requirements/Assumptions . . 4 4-156

4.2.5.2.5 Key Technical Requirements ........... 4-156

4.2.5.2.6 Project Safety Authorization Basis/NEPA and Permits ....................... 4-164

4.2.5.2.7 Other Requirements and Planning Assumptions, Including DNFSB $\ldots \ldots \ldots \ldots \ldots \ldots \ldots$ 4-164

4.2.5.2.8 Interfaces . . . . . . . . . . . . . . . . . . 4-165

4.2.5.2.9 Logic Diagram . . . . . . . . . . . . . . . 4-165

4.2.5.2.10 Requirements References ............. 4-165

4.2.5.2.11 Additional Planning Assumptions . . . . . . . . . . 4-165

4.3 ER Project . . . . . . . . . . . . . . . . . . . . . . 4 4 168

4.3.1 100 Area Source Remedial Action Project . . . . . . . . . . . 4-168

4.3.1.1 Project Description Summary . . . . . . . . . . . 4 4-168

4.3.1.2 Geographic Requirements/Assumptions . . . . . . . . . . 4-169

4.3.1.3 Material and Waste Flow Requirements/Assumptions . . . . 4-170

4.3.1.4 Facility Life-Cycle Requirements/Assumptions ... . . . . . 4-170

4.3.1.5 Project Safety Authorization Basis/NEPA and Permits . . . 4-170

4.3.1.6 Other Requirements and Planning Assumptions ... . . . . 4-170

4.3.1.7 Interfaces . . . . . . . . . . . . . . . . . . . . . 4-170

4.3.1.8 Logic Diagram . . . . . . . . . . . . . . . . . . 4-170

4.3.1.9 Requirements References . . . . . . . . . . . . . . . . 4 4-170

4.3.1.10 Planning Assumptions . . . . . . . . . . . . . . 4-170

4.3.2 200 Area Source Remedial Action Project . . . . . . . . . 4-171

4.3.2.1 Project Description Summary . . . . . . . . . . . . . 4-171

4.3.2.2 Geographic Requirements/Assumptions . . . . . . . . 4-172

4.3.2.3 Material and Waste Flow Requirements/Assumptions . . . 4-172

4.3.2.4 Facility Life-Cycle Requirements/Assumptions . . . . . . . 4-172

4.3.2.5 Project Safety Authorization Basis/NEPA and Permits . . . 4 4-172

4.3.2.6 Other Requirements and Planning Assumptions . . . . . 4 4-173

4.3.2.7 Interfaces . . . . . . . . . . . . . . . . . . . . . . 4-173

4.3.2.8 Logic Diagram ... . . . . . . . . . . . . . . . . . . . 4-173

4.3.2.9 Requirements References . . . . . . . . . . . . . . . . 4-173

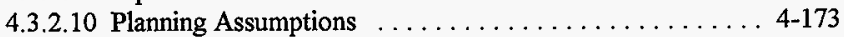

4.3.3 300 Area Source Remedial Action Project $\ldots \ldots \ldots \ldots \ldots \ldots$. 4-174

4.3.3. I Project Description Summary . . . . . . . . . . . . . . . . . 4 4-174

4.3.3.2 Geographic Requirements/Assumptions . . . . . . . 4-174

4.3.3.3 Material and Waste Flow Requirements/Assumptions . . . . 4-175

4.3.3.4 Facility Life-Cycle Requirements/Assumptions . . . . . . . 4 4-175

4.3.3.5 Project Safety Authorization Basis/NEPA and Permits ... 4 4-175 
DOE/RL-97-55

Revision 0

\section{CONTENTS (cont)}

4.3.3.6 Other Requirements and Planning Assumptions . . . . . . 4-175

4.3.3.7 Interfaces . . . . . . . . . . . . . . . . . . . 4-175

4.3.3.8 Logic Diagram . . . . . . . . . . . . . . . . . . . . . 4-176

4.3.3.9 Requirements References . . . . . . . . . . . . . 4-176

4.3.3.10 Planning Assumptions $\ldots \ldots \ldots \ldots \ldots \ldots \ldots \ldots$ 4-176

4.3.4 ER.Waste Disposal Project . . . . . . . . . . . . . . . . 4-176

4.3.4.1 Project Description Summary . . . . . . . . . . . . 4 4-176

4.3.4.2 Geographic Requirements/Assumptions . . . . . . . . 4-177

4.3.4.3 Material and Waste Flow Requirements/Assumptions . . . . 4-178

4.3.4.4 Facility Life-Cycle Requirements/Assumptions . . . . . . . . 4-178

4.3.4.5 Project Safety Authorization Basis/NEPA and Permits . . . 4-178

4.3.4.6 Other Requirements and Planning Assumptions ... . . . 4-178

4.3.4.7 Interfaces . . . . . . . . . . . . . . . . . . . 4-178

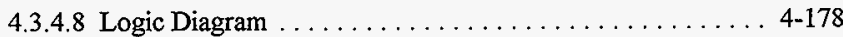

4.3.4.9 Requirements References . . . . . . . . . . . . . . . . . 4-179

4.3.4.10 Planning Assumptions . . . . . . . . . . . . . . . . . 4-179

4.3.5 S\&M Project . . . . . . . . . . . . . . . . . . . 4-179

4.3.5.1 Project Description Summary . . . . . . . . . . . . . . . 4-179

4.3.5.2 Geographic Requirements/Assumptions ........... 4-180

4.3.5.3 Material and Waste Flow Requirements/Assumptions . . . 4 4-180

4.3.5.4 Facility Life-Cycle Requirements/Assumptions ... . . . . . 4-180

4.3.5.5 Project Safety Authorization Basis/NEPA and Permits . . . 4-183

4.3.5.6 Other Requirements and Planning Assumptions . . . . . . 4-183

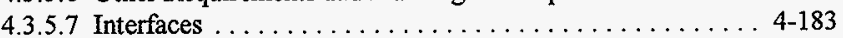

4.3.5.8 Logic Diagram ... . . . . . . . . . . . . . . . . . . 4-183

4.3.5.9 Requirements References . . . . . . . . . . . . . 4-183

4.3.5.10 Planning Assumptions $\ldots \ldots \ldots \ldots \ldots \ldots \ldots \ldots .4 . \ldots \ldots 3$

4.3.6 D\&D Project .......................... 4-183

4.3.6.1 Project Description Summary ... . . . . . . . . . . . . 4-184

4.3.6.2 Geographic Requirements/Assumptions .......... 4-184

4.3.6.3 Material and Waste Flow Requirements/Assumptions ... . 4-185

4.3.6.4 Facility Life-Cycle Requirements/Assumptions . . . . . . . 4-185

4.3.6.5 Project Safety Authorization Basis/NEPA and Permits . . . . 4-187

4.3.6.6 Other Requirements and Planning Assumptions . . . . . 4 4-187

4.3.6.7 Interfaces . . . . . . . . . . . . . . . . . . . . . . . 4-187

4.3.6.8 Logic Diagram . . . . . . . . . . . . . . . . . . . . . . . . 4-187

4.3.6.9 Requirements References . . . . . . . . . . . . . . . . 4-187

4:3.6.10 Planning Assumptions $\ldots \ldots \ldots \ldots \ldots \ldots \ldots \ldots . .4 .188$

4.3.7 Long-Term S\&M Project . . . . . . . . . . . . . . . . . 4-188

4.3.7.1 Project Description Summary . . . . . . . . . . . . . . 4-188

4.3.7.2 Geographic Requirements/Assumptions . . . . . . . . 4-189

4.3.7.3 Material and Waste Flow Requirements/Assumptions . . . . 4-189

4.3.7.4 Facility Life-Cycle Requirements/Assumptions . . . . . . . . . 4-189 
DOE/RL-97-55

Revision 0

\section{CONTENTS (cont)}

4.3.7.5 Project Safety Authorization Basis/NEPA and Permits . . . 4-189

4.3.7.6 Other Requirements and Planning Assumptions . . . . . . . 4-189

4.3.7.7 Interfaces . . . . . . . . . . . . . . . . . . . 4-190

4.3.7.8 Logic Diagram . . . . . . . . . . . . . . . . . . 4-190

4.3.7.9 Requirements References . . . . . . . . . . . . . 4-190

4.3.7.10 Planning Assumptions . . . . . . . . . . . . . . 4 4-190

4.3.8 Groundwater Management Project ................... 4-190

4.3.8.1 Project Description Summary ............... 4-190

4.3.8.2 Geographic Requirements/Assumptions . .......... 4-191

4.3.8.3 Material and Waste Flow Requirements/Assumptions . . . . 4-192

4.3.8.4 Facility Life-Cycle Requirements/Assumptions . . . . . . . . 4-192

4.3.8.5 Project Safety Authorization Basis/NEPA and Permits . . . 4-192

4.3.8.6 Other Requirements and Planning Assumptions ...... . . 4-193

4.3.8.7 Interfaces . . . . . . . . . . . . . . . . . . . . . . 4-193

4.3.8.8 Logic Diagram . . . . . . . . . . . . . . . . . . . . . . 4-193

4.3.8.9 Requirements References ................ 4-193

4.3.8.10 Planning Assumptions . . . . . . . . . . . . . . . 4-193

4.3.9 N Reactor Deactivation Project . . . . . . . . . . . . . . . . 4-193

4.3.9.1 Project Description Summary . . . . . . . . . . . . . . . 4-194

4.3.9.2 Geographic Requirements/Assumptions .......... 4-194

4.3.9.3 Material and Waste Flow Requirements/Assumptions . . . . 4-194

4.3.9.4 Facility Life-Cycle Requirements/Assumptions . . . . . . . . 4-194

4.3.9.5 Project Safety Authorization Basis/NEPA and Permits . . . 4-195

4.3.9.6 Other Requirements and Planning Assumptions ...... . 4-195

4.3.9.7 Interfaces . . . . . . . . . . . . . . . . . . . . . . . 4-195

4.3.9.8 Logic Diagram . . . . . . . . . . . . . . . . . 4-195

4.3.9.9 Requirements References . . . . . . . . . . . . . . . 4-195

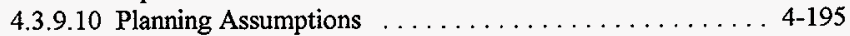

4.3.10 ER Project Management and Support .............. 4-196

4.3.10.1 Project Description Summary . . . . . . . . . . 4-196

4.3.10.2 Geographic Requirements/Assumptions .......... 4-197

4.3.10.3 Material and Waste Flow Requirements/Assumptions . . . 4-197

4.3.10.4 Facility Life-Cycle Requirements/Assumptions . . . . . . 4 4-197

4.3.10.5 Project Safety Authorization Basis/NEPA and Permits . . 4-198

4.3.10.6 Other Requirements and Planning Assumptions . . . . . . 4-198

4.3.10.7 Interfaces . . . . . . . . . . . . . . . . . . . . . . . . . 4-198

4.3.10.8 Logic Diagram . . . . . . . . . . . . . . . . 4-198

4.3.10.9 Requirements References . . . . . . . . . . . . 4-198

4.3.10.10 Planning Assumptions . . . . . . . . . . . . . 4-198

4.4 PACIFIC NORTHWEST NATIONAL LABORATORY WASTE

MANAGEMENT PROJECT . . ................. 4-200

4.4.1 Pacific Northwest National Laboratory Waste Management . . . . 4-200

4.4.1.1 Project Description Summary . . . . . . . . . . . . . . 4-200 
DOE/RL-97-55

Revision 0

CONTENTS (cont)

4.4.1.2 Geographic Requirements/Assumptions . . . . . . . . 4-201

4.4.1.3 Material and Waste Flow Requirements/Assumptions . . . . 4-202

4.4.1.4 Facility Life-Cycle Requirements/Assumptions . . . . . . . 4-203

4.4.1.5 Project Safety Authorization Basis/NEPA and Permits . . . 4-206

4.4.1.6 Interfaces ....................... 4-206

4.4.1.7 Logic Diagram . . . . . . . . . . . . . . . . . 4-206

4.4.1.8 Requirements References . . . . . . . . . . . . . 4-207

4.4.1.9 Planning Assumptions $\ldots \ldots \ldots \ldots \ldots \ldots \ldots \ldots$ 4-208

4.5 TWRS PRIVATIZATION PHASE I $\ldots \ldots \ldots \ldots \ldots \ldots \ldots \ldots \ldots \ldots$ 4-211

4.5.1 Privatization Phase I Project $\ldots \ldots \ldots \ldots \ldots \ldots \ldots \ldots \ldots \ldots \ldots \ldots \ldots \ldots, 211$

4.5.1.1 Project Description Summary . . . . . . . . . . . 4-211

4.5.1.2 Geographic Requirements/Assumptions ......... 4-211

4.5.1.3 Material and Waste Flow Requirements/Assumptions . . . . 4-212

4.5.1.4 Facility Life-Cycle Requirements and Assumptions . . . . . 4 4-212

4.5.1.5 Project Safety Authorization Basis/NEPA and Permits ... . 4-213

4.5.1.6 Other Requirements and Planning Assumptions . . . . . . 4-214

4.5.1.7 Interfaces ........................ 4-215

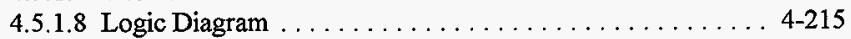

4.5.1.9 Requirements References ................ 4-216

4.6 TWRS PRIVATIZATION PHASE II $\ldots \ldots \ldots \ldots \ldots \ldots \ldots \ldots \ldots \ldots .4 .218$

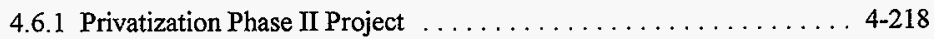

4.6.1.1 Project Description Summary . . . . . . . . . . . . 4-218

4.6.1.2 Geographic Requirements/Assumptions ......... 4-218

4.6.1.3 Material and Waste Flow Requirements .......... . 4-219

4.6.1.4 Facility Life-Cycle Requirements/Assumptions . . . . . . . 4 4-219

4.6.1.5 Project Safety Authorization Basis/NEPA and Permits . . . 4-220

4.6.1.6 Other Requirements and Planning Assumptions ...... 4-220

4.6.1.7 Interfaces . . . . . . . . . . . . . . . . . . . . . 4-221

4.6.1.8 Logic Diagram . . . . . . . . . . . . . . . . . . 4-222

4.6.1.9 Requirements References . . . . . . . . . . . . 4-222

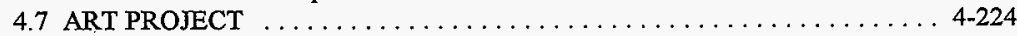

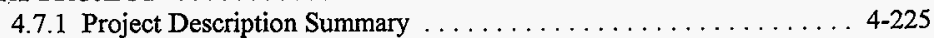

4.7.2 Geographic Requirements/Assumptions . . . . . . . . . 4-228

4.7.3 Material and Waste Flow Requirements/Assumptions . . . . . . . 4-229

4.7.4 Facility Life-Cycle Requirements/Assumptions . . . . . . . . . . . 4-230

4.7.5 Project Safety Authorization Basis/NEPA and Permits . . . . . . 4-231

4.7.6 Other Requirements and Planning Assumptions .......... 4-232

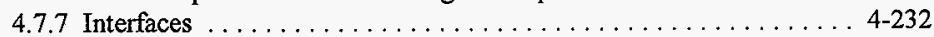

4.7.8 Logic Diagram . . . . . . . . . . . . . . . . . . . . . 4-233

4.7.9 Requirements References $\ldots \ldots \ldots \ldots \ldots \ldots \ldots \ldots \ldots \ldots .4 .233$

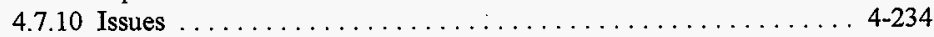

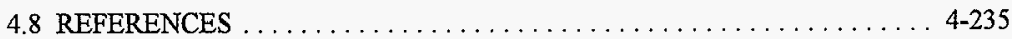


DOE/RL-97-55

Revision 0

\section{LIST OF FIGURES}

1-1 Basic Site Documents . . . . . . . . . . . .

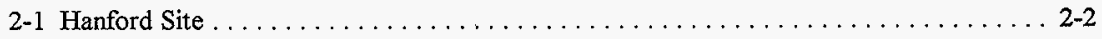

3-1 Project Hanford Breakdown Structure $\ldots \ldots \ldots \ldots \ldots \ldots \ldots \ldots \ldots \ldots \ldots \ldots \ldots \ldots \ldots \ldots .2$

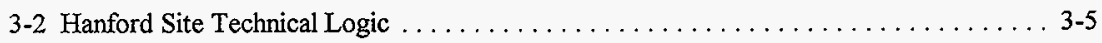

4-1 Tank Waste Remediation System Material Flow/Logic . . . . . . . . . . . . . 4-4

4-2 Tank Waste Remediation System Program Logic $\ldots \ldots \ldots \ldots \ldots \ldots \ldots . . \ldots \ldots$

4-3 Logic Diagram for the Solid Waste Subproject $\ldots \ldots \ldots \ldots \ldots \ldots \ldots \ldots \ldots .64$

4-4 Logic Diagram for the Liquid Waste Program ................. 4-72

4-5 Logic Diagram for the Spent Nuclear Fuel Project $\ldots \ldots \ldots \ldots \ldots \ldots \ldots \ldots$ 4-89

4-6 Logic Diagram for the Facility Stabilization Project $\ldots \ldots \ldots \ldots \ldots \ldots \ldots \ldots$. $4-99$

4-7 Logic Diagram for the Landlord Project ................... 4-155

4-8 Logic Diagram for the Infrastructure Project $\ldots \ldots \ldots \ldots \ldots \ldots \ldots \ldots \ldots .4 .166$

4-9 Logic Diagram for the Environmental Restoration Project . . . . . . . . . . . . 4-169

4-10 Logic Diagram for the Pacific Northwest National Laboratory Environmental Restoration Work. . . . . . . . . . . . . . . . . . . . . . . . . . 4-207

\section{LIST OF TABLES}

3-1 Material and Waste External Inputs to Hanford Site $\ldots \ldots \ldots \ldots \ldots \ldots \ldots \ldots .4 .4$

3-2 Material and Waste External Outputs from Hanford Site . . . . . . . . . . 3-4 
DOE/RL-97-55

Revision 0

\section{LIST OF TERMS}

AKART

ARP

ART

AWP

BAT

BIO

BMI

BNFL

BWHC

$\mathrm{CCC}$

CERCLA

$\mathrm{CH}$

Cs

CSB

CVD

CVD

CWC

D\&D

DESH

DNFSB

DOE

DOT

DP

DQO

DST

DYN

Ecology

EM

EM-30

EM-40

EM-60

EM-70

EMSL

ER

ERC

ERDF

ES\&H

ESPC

ETF

FDH

FERMCO all known, available, and reasonable treatment

Area Revitalization Project

Advanced Reactors Transition

annual work plan

best available technology

basis for interim operations

Battelle Memorial Institute

British Nuclear Fuels, Ltd.

B\&W Hanford Company

core component container

Comprehensive Environmental Response, Compensation, and Liability Act

of 1980

contact-handled

cesium

Canister Storage Building

cold vacuum drying

Cold Vacuum Drying Facility

Central Waste Complex

decontamination and decommissioning

DE\&S Hanford, Inc.

Defense Nuclear Facilities Safety Board

U.S. Department of Energy

U.S. Department of Transportation

Defense Programs

data quality objective

double-shell tank

DynCorp Tri-Cities Services, Inc.

Washington State Department of Ecology

U.S. Department of Energy, Office of Environmental Management

U.S. Department of Energy, Office of Waste Management

U.S. Department of Energy, Office of Environmental Restoration

U.S. Department of Energy, Office of Nuclear Material and Facility

Stabilization

U.S. Department of Energy, Office of Site Operations

Environmental and Molecular Sciences Laboratory

Environmental Restoration

Environmental Restoration Contractor

Environmental Restoration Disposal Facility

Environmental, Safety, and Health

Energy Savings Performance Contract

Effluent Treatment Facility

Fluor Daniel Hanford, Inc.

Fernald Environmental Restoration Management Corporation 
DOE/RL-97-55

Revision 0

FFTF

FMEF

FSAR

FSP

FSS

FY

HAMMER

HASP

HASQARD

HCS

HEHF

HEU

HLW

HRA

IAEA

IHLW

ILAW

INEEL

ISA

ISC

LAW

LDR

LERF

LLW

LMHC

M\&I

$\mathrm{MCO}$

MLLW

MOU

MSP

MT

MTRU

MUST

MWSTP

MYWP

$\mathrm{Na}$

$\mathrm{NaK}$

NEPA

NF

NM

NPDES

Pacific Northwest

PBS

PCB

PFP

PHMC
Fast Flux Test Facility

Fuels and Materials Examination Facility

final safety analysis report

Facility Stabilization Project

Fuel Supply Shutdown

fiscal year

Hazardous Materials Management and Emergency Response

Hanford Analytical Services Program

Hanford Analytical Services Quality Requirements Document

Hot Conditioning System

Hanford Environmental Health Foundation

highly enriched uranium

high-level waste

Hanford Remedial Action

International Atomic Energy Agency

immobilized high-level waste

immobilized low-activity waste

Idaho National Environmental and Engineering Laboratory

interim storage area

interim storage cask

low-activity waste

land disposal restriction

Liquid Effluent Retention Facility

low-level waste

Lockheed Martin Hanford Corporation

management and integration

multi-canister overpack

mixed low-level waste

Memorandum of Understanding

Management Support Project

metric ton

mixed transuranic

miscellaneous underground storage tank

MLLW Stabilization Treatment Program

multi-year work plan

sodium

sodium-potassium alloy

National Environmental Policy Act of 1969

nuclear fuel

nuclear material

National Pollutant Discharge Elimination System

Pacific Northwest National Laboratory

project baseline summary

polychlorinated biphenyl

Plutonium Finishing Plant

Project Hanford Management Contract 
PMP

PRTR

PUREX

PWR

RARA

RCRA

RFP

$\mathrm{RH}$

RL

RID

RLIP

ROD

S\&M

S/RTD

SAS

SNF

SNM

$\mathrm{Sr}$

SST

SWT

TBD

TEDF

Th

TP

TRIGA

TRU

TRUPACT

TRUSAF

TSCA

TSD

TWRS

U

USACE

USQ

WAC

WESF

WIPP

WMH

WRAP

WSCF project management plan

Plutonium Recycle Test Reactor

Plutonium-Uranium Extraction

pressurized water reactor

radiation area remediation action

Resource Conservation and Recovery Act of 1976

Request for Proposal

remote-handled

U.S. Department of Energy, Richland Operations Office

RL Implementing Directive

RL Implementing Procedure

Record of Decision

surveillance and maintenance

standards/requirements identification document

safeguards and security

spent nuclear fuel

special nuclear material

strontium

single-shell tank

Solid Waste Treatment

to be determined

Treated Effluent Disposal Facility

thorium

Transition Project

Training Reactor, Isotopics, General Atomics

transuranic

transuranic package transporter

Transuranic Waste Storage and Assay Facility

Toxic Substances Control Act of 1976

treatment, storage, and/or disposal

Tank Waste Remediation System

uranium

U.S. Army Corp of Engineers

unreviewed safety question

waste acceptance criteria

Waste Encapsulation and Storage Facility

Waste Isolation Pilot Plant

Waste Management Federal Services of Hanford, Inc.

Waste Receiving and Processing

Waste Sampling and Characterization Facility 
DOE/RL-97-55

Revision 0

\section{HANFORD SITE ENVIRONMENTAL MANAGEMENT SPECIFICATION}

\subsection{PURPOSE AND INTRODUCTION}

\subsection{INTENDED USE}

The U.S. Department of Energy, Richland Operations Office (RL) uses this Hanford Site Environmental Management Specification (Specification) to document top-level mission requirements and planning assumptions for the prime contractors involved in Hanford Site cleanup and infrastructure activities under the responsibility of the U.S. Department of Energy, Office of Environmental Management (EM). This Specification describes at a top level the activities, facilities, and infrastructure necessary to accomplish the cleanup of the Hanford Site and assigns this scope to Site contractors and their respective projects.

This Specification also references the key National Environmental Policy Act of 1969 (NEPA), Comprehensive Environmental Response, Compensation, and Liability Act of 1980 (CERCLA), and safety documentation necessary to accurately describe the cleanup at a summary level.

The information contained in this document reflects RL's application of values, priorities, and critical success factors expressed by those involved with and affected by the Hanford Site project. The prime contractors and their projects develop complete baselines and work plans to implement this Specification. These lower-level documents and the data that support them, together with this Specification, represent the full set of requirements applicable to the contractors and their projects.

Figure 1-1 shows the relationship of this Specification to the other basic Site documents.

Similarly, the documents, orders, and laws referenced in this specification represent only the most salient sources of requirements. Current and contractual reference data contain a complete set of source documents.

\subsection{RELATIONSHIP TO OTHER DOCUMENTS AND PROCESSES}

\subsubsection{Tribal, Regulatory, and Public Involvement in Decision Making}

A goal of RL has been to move toward earlier tribal, regulatory, and public involvement in its planning and decision-making processes to share information and receive valuable input and recommendations during the formative stages of planning and decision making. To accomplish this goal, early drafts of planning guidance and predecisional analyses have been released, quite often before this material has been seen or reviewed by U.S. Department of Energy (DOE) management. This means that the material released may not be accurate and fully verified and, 


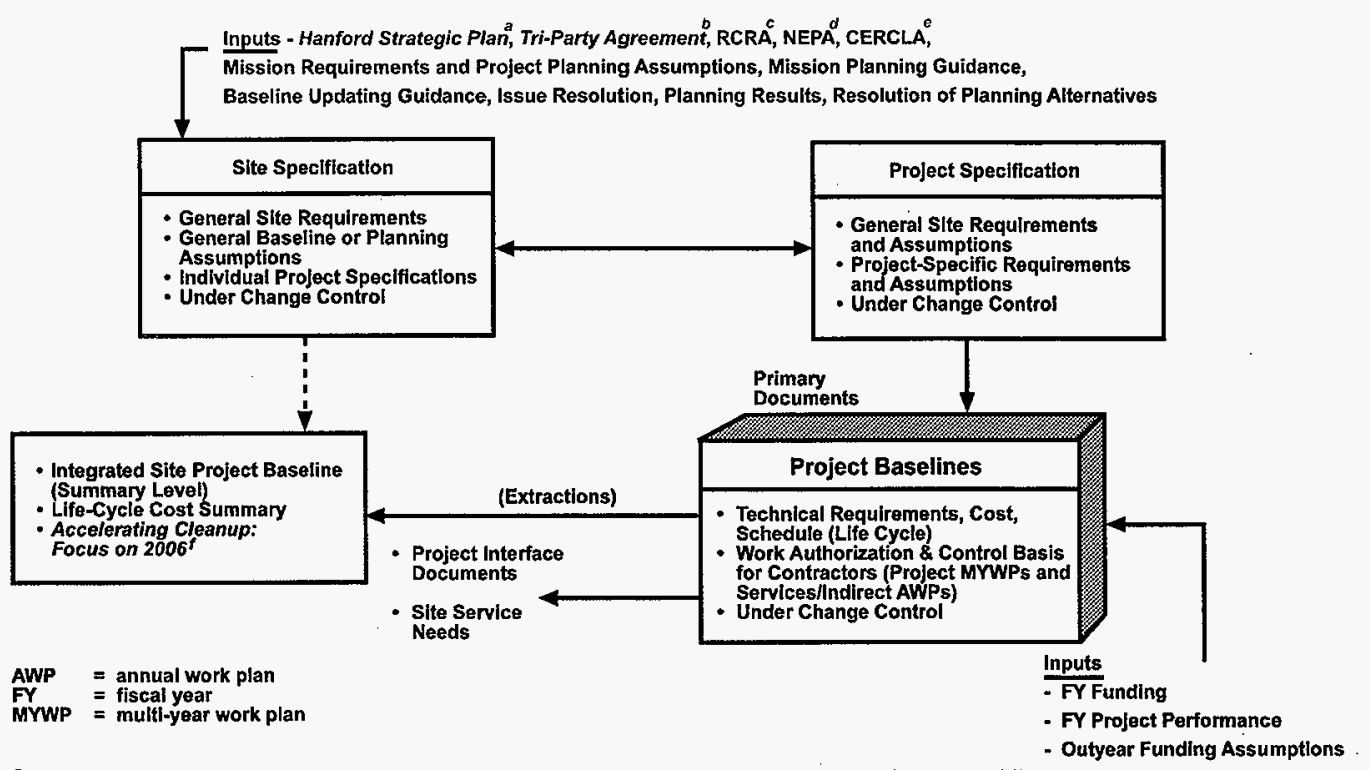

a RL, 1996, Hanford Strategic Plan, DOE/RL-96-92, Rev. O, U.S. Department of Energy, Richland Operations Office, Richland, Washington.

${ }^{b}$ Ecology, EPA, and DOE, 1996, Hanford Federal Facility Agreement and Consent Order, as amended, Washington State Department of Ecology, U. S. Environmental Protection Agency, and

U.S. Department of Energy, Olympia, Washington.

${ }^{\circ}$ Resource Conservation and Recovery Act of 1976, 42 USC 6901, et seq.

dNational Environmental Policy Act of 1969, 42 USC 4321, et seq.

Comprehensive Environmental Response, Compensation, and Liability Act of 1980, 42 USC 9601, et seq.

'RL, 1997, Accelerating Cleanup: Focus on 2006, DOE/RL-97-57, U.S. Department of Energy, Richland Operations Office, Richland, Washington. 


\section{DOE/RL-97-55 \\ Revision 0}

therefore, may be inconsistent with other documents and may not reflect the final position of the DOE. At this time, the DOE believes that it is preferable to have such open involvement in the DOE planning processes. Those who receive such early draft documents should recognize that the documents are by nature incomplete, unreviewed to a large extent, and potentially contradictory.

\subsubsection{Decision-Related Actions}

In general terms, decision-related actions by the DOE should be viewed in three major categories: as portions of the "planning process," the "decision process," and "decision implementation."

The planning process involves such areas for activities and documentation as the following:

- Blue sky thinking

- Strategic thinking

- Planning alternatives development

- Preliminary engineering

- Preliminary alternative analysis

- Field activities to do investigation and characterization to support analysis

- Budget activities and funding to cover "planning activities."

The decision process involves such activities as the following:

- Analysis of the results from the planning process

- Formal NEPA and CERCLA decisions as appropriate where NEPA and CERCLA decisions are documented in Records of Decision (ROD), Findings of No Significant Impact, and Action Memorandum

- Budget activities and funding to cover the decision process and the implementation of decisions after they are completed.

The decision implementation involves the following:

- Final engineering

- Field activities to carry out the decision.

\subsubsection{NEPA and CERCLA Considerations}

In general, NEPA regulations prohibit the DOE from taking any major federal action that would adversely impact the environment or prejudice the final decision in an NEPA ROD before the ROD is approved. The CERCLA process, as followed by the DOE, includes consideration of 
DOE/RL-97-55

Revision 0

NEPA values so that a CERCLA ROD is sufficient authority to implement a decision without a parallel NEPA process and NEPA ROD. The NEPA and CERCLA requirements allow the planning process as described above to be performed before entering a formal decision process.

\subsubsection{RL Planning Documents}

The Hanford Strategic Plan (RL 1996), Mission Planning Guidance and Baseline Updating Guidance (see DOE/RL-97-52 [RL 1997a]), DOE/EIS-0222D, Draft Hanford Remedial Action Environmental Impact Statement and Comprehensive Land Use Plan (HRA-EIS) (DOE 1996), and Accelerating Cleanup: Focus on 2006 (RL 1997b) are all planning documents. They provide guidance and direction for planning and analyses that are not in all cases yet covered by NEPA or CERCLA documents. This is planning process work and, as such, does not need a final NEPA ROD, but instead shows where NEPA and CERCLA decision processes will be needed. The resultant NEPA and CERCLA RODs and Hanford Federal Facility Agreement and Consent Order (Tri-Party Agreement) (Ecology et al. 1996) commitments take precedence over, and will cause changes and adjustments to be made to, the Hanford Strategic Plan, Mission Planning Guidance and Baseline Updating Guidance, Accelerating Cleanup: Focus on 2006, or other planning process documents. For a complete list of NEPA and CERCLA documentation, see HNF-SP-0903, National Environmental Policy Act Source Guide for the Hanford Site (FDH 1997).

\subsection{AUTHORITY}

This Specification describes the work that the DOE expects from the prime contractors, and is a contractually enforceable document.

\subsection{REQUIREMENTS AND PLANNING ASSUMPTIONS}

Throughout this document, the terms "requirement" and "planning assumption" are used frequently. A requirement is derived from an approved document that has been issued for action. These include statutes, approved DOE Orders, Defense Nuclear Facilities Safety Board (DNFSB) implementation plans, and NEPA and CERCLA RODs. Planning assumptions are derived from draft documents and are used within the constraints of the law to develop project plans for budgetary and technical planning. Examples include draft EIS and CERCLA documentation, implementation plans and studies still under review and comment, and other similar sources. Planning assumptions may also be explicitly identified in approved requirements documents.

\subsection{REFERENCES}

Comprehensive Environmental Response, Compensation, and Liability Act of 1980 , 42 USC 9601 , et seq. 


\section{DOE/RL-97-55}

\section{Revision 0}

DOE, 1996, Draft Hanford Remedial Action Environmental Impact Statement and Comprehensive Land Use Plan, DOE/EIS-0222D, U.S. Department of Energy, Washington, D.C.

Ecology, EPA, and DOE, 1996, Hanford Federal Facility Agreement and Consent Order, as amended, Washington State Department of Ecology, U.S. Environmental Protection Agency, and U.S. Department of Energy, Olympia, Washington.

FDH, 1997, National Environmental Policy Act Source Guide for the Hanford Site, HNF-SP-0903, Fluor Daniel Hanford, Inc., Richland, Washington.

National Environmental Policy Act of 1969, 42 USC 4321, et seq.

RL, 1996, Hanford Strategic Plan, DOE/RL-96-92, Rev. 0, U.S. Department of Energy, Richland Operations Office, Richland, Washington.

RL, 1997a, Basic Planning and Work Performance of Hanford Site Environmental Management Activities, DOE/RL-97-52, U.S. Department of Energy, Richland Operations Office, Richland, Washington.

RL, 1997b, Accelerating Cleanup: Focus on 2006, DOE/RL-97-57, U.S. Department of Energy, Richland Operations Office, Richland, Washington. 
DOE/RL-97-55

Revision 0

This page intentionally left blank. 
DOE/RL-97-55

Revision 0

\subsection{HANFORD SITE ENVIRONMENTAL MANAGEMENT MISSION AND SITE DESCRIPTION}

\subsection{HANFORD SITE VISION}

The Hanford Site has dealt with legacy wastes, and has become a national environmental science and technology asset performing new missions.

\subsection{HANFORD SITE ENVIRONMENTAL MANAGEMENT MISSIONS}

Hanford Site missions are to safely clean up and manage the Site's legacy wastes and to develop and deploy science and technology. Through these missions, the Site contributes economic diversification of the region.

\subsection{GEOGRAPHIC AREAS, REQUIREMENTS, AND PLANNING ASSUMPTIONS}

The Hanford Site's requirements and planning assumptions for land-use planning and establishment of cleanup levels and disposal requirements are as follows.

\section{Requirements:}

- The DOE shall ensure that all geographic areas, inactive waste sites, and future disposal sites have cleanup requirements that are set by either the Resource Conservation and Recovery Act of 1976 (RCRA), CERCLA, or NEPA.

- The DOE shall undertake a comprehensive land-use planning process for the entire Hanford Site in compliance with DOE Order 430.1, Life-Cycle Asset Management (DOE 1995).

Planning Assumptions: The future state of the Hanford Site as it is projected to be in 2046 is summarized as follows (also refer to Figure 2-1). These projections are specified in the HRA-EIS (DOE 1996).

- Access to DOE land used for disposal of radioactive waste will remain restricted as long as necessary to ensure adequate protection of human health and the environment.

- A final decision regarding the Comprehensive Land Use Plan will be made in the NEPA process or the HRA-EIS. Final decisions on cleanup levels for individual waste sites will be made in the CERCLA and NEPA ROD process. 


\section{DOE/RL-97-55}

Revision 0

Figure 2-1. Hanford Site.

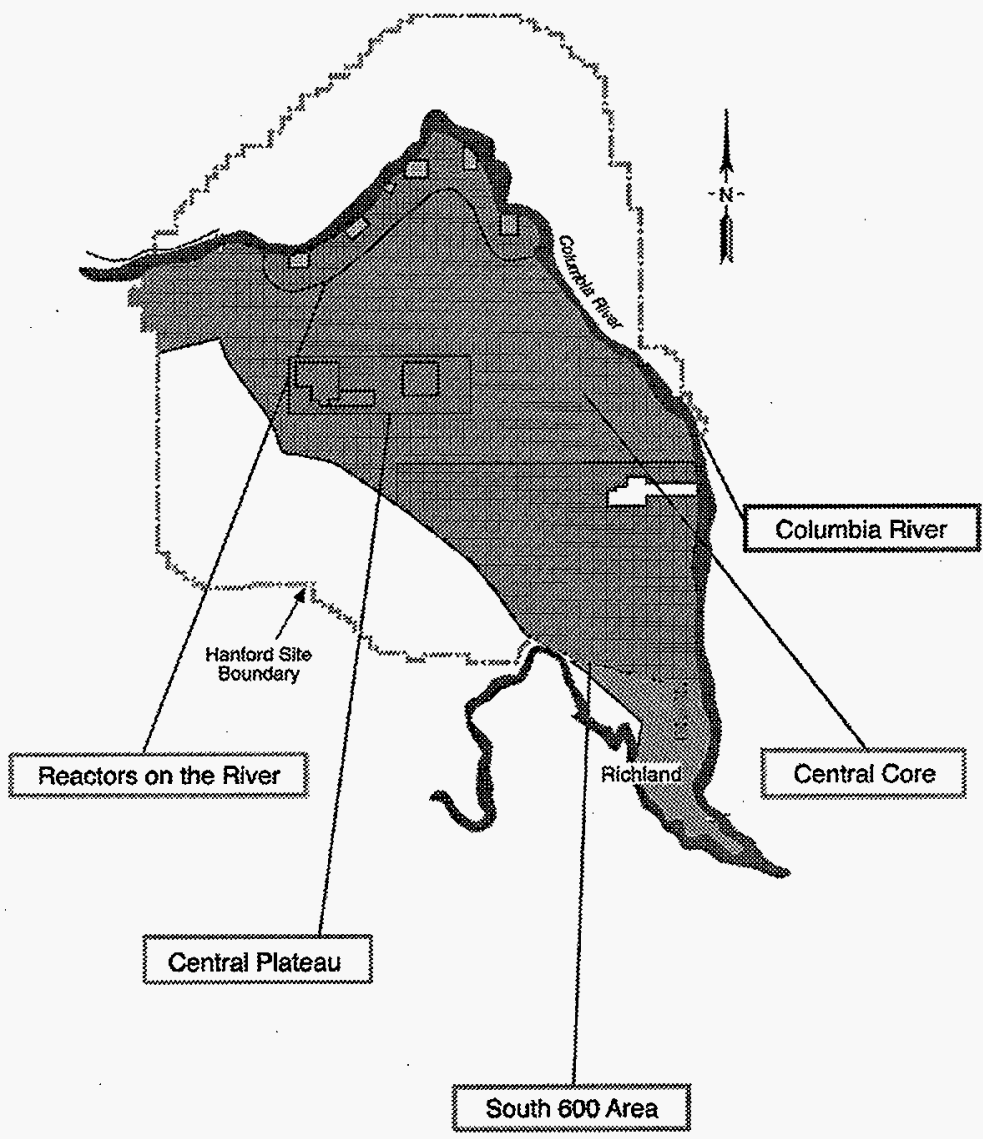

H97050264.1 


\section{Reactors on the River}

\section{Requirements:}

- HRA-EIS (DOE 1996).

\section{Planning Assumptions:}

- Remove and/or stabilize spent nuclear fuel (SNF), surplus facilities, and waste sites to protect groundwater and the Columbia River and to ensure protection of people, the environment, and natural/cultural resources. Pending Congressional action on the Wild and Scenic River designation, use will continue to be restricted; sensitive ecological, cultural, and Native American resources will be protected.

\section{Central Plateau}

\section{Requirements:}

- None.

\section{Planning Assumptions:}

- The 200 Areas and Central Plateau will be used to manage nuclear materials (NM), the collection and disposal of waste materials that remain onsite, and for other related and compatible uses. Cleanup levels and disposal standards will be established that are consistent with these long-term uses.

\section{South 600 Area}

\section{Requirements:}

- None.

\section{Planning Assumptions:}

- The 300 Area waste sites, materials, and facilities will be remediated to allow industrial and economic diversification opportunities. The federal government will retain ownership of land in and adjacent to the 300 and 400 Areas, but will lease land for private and public uses to support regional industrial and economic development. Excess land within the 1100 Area will be targeted for transition to non-federal ownership. 


\section{Central Core}

\section{Requirements:}

- None.

\section{Planning Assumptions:}

- This area will remain in federal ownership consistent with safety analysis boundaries and continued waste management operations in the 200 Areas. This area will be available for other federal programs or leased for non-federal uses, consistent with appropriate recognition of cultural and ecosystem values.

\section{Columbia River}

\section{Requirements:}

- None.

\section{Planning Assumptions:}

- Pending Congressional action on the Wild and Scenic River designation, use will continue to be restricted; sensitive ecological, cultural, and Native American resources will be protected.

\subsection{MATERIAL CATEGORIES, REQUIREMENTS, AND PLANNING ASSUMPTIONS}

\section{Requirements:}

- 60 FR 2860, "Programmatic Spent Nuclear Fuel Management and Idaho National Engineering Laboratory Environmental Restoration and Waste Management Program, Part III"

- 61 FR 10736, "Management of Spent Nuclear Fuel from the K Basins at the Hanford Site, Richland, WA."

\section{Planning Assumptions:}

- Spent nuclear fuels will be prepared and packaged, as necessary, for safe, dry, interim storage onsite, and shipped offsite for disposal in a national repository. 


\section{DOE/RL-97-55}

Revision 0

\section{Groundwater}

\section{Requirements:}

- None.

\section{Planning Assumptions:}

- Groundwater use remains restricted for a yet-to-be-determined period. Final cleanup levels will be established with the individual RODs or Hanford Site RCRA permit modifications.

- Groundwater use remains restricted for a yet-to-be-determined period pending decisions on final attainable cleanup levels. Remediation actions will help protect the Columbia River and the near-shore environment, reduce contamination entering the groundwater, and control the migration of plumes that threaten groundwater quality beyond the boundaries of the Central Plateau.

\section{Soil Sites}

\section{Requirements:}

- Contaminated soil sites will be treated to levels supportive of future use targets or regulator-specified levels for each geographic area as prescribed by CERCLA and RCRA decisions.

\section{Planning Assumptions:}

- None.

\section{Facilities Transition}

\section{Requirements:}

- None.

\section{Planning Assumptions:}

- Safe, stable, secure onsite storage will be provided for all NM pending decisions on final disposition or until beneficial offsite uses are identified. Facilities without identified future uses will be transitioned to low-cost, stable, deactivated conditions (requiring minimal surveillance and maintenance $[S \& M]$ ) pending eventual decontamination and decommissioning (D\&D) and removal or closure. 


\section{Facilities D\&D}

\section{Requirements:}

- None.

\section{Planning Assumptions:}

- Surplus facilities will be decommissioned and decontaminated sufficiently to enable removal or closure through entombment.

\section{Solid Waste}

\section{Requirements:}

- None.

\section{Planning Assumptions:}

- Solid wastes will be dispositioned consistent with national policies for management of transuranic (TRU) waste, low-level waste (LLW), mixed low-level waste (MLLW), and hazardous wastes. The Hanford Site will continue to receive onsite and offsite wastes for disposal in the 200 Areas.

- The DOE programmatic decisions are identified in DOE/EIS-0200F, Final Waste Management Programmatic Environmental Impact Statement for Managing Treatment, Storage, and Disposal of Radioactive and Hazardous Waste (DOE 1997a).

\section{Radioactive Tank Waste}

\section{Requirements:}

- Tank Waste Remediation System Environmental Impact Statement Record of Decision, Hanford Site, Richland, Washington (DOE 1997b)

\section{Planning Assumptions:}

- Tank waste from single-shell tanks (SST) and double-shell tanks (DST) will be retrieved for immobilization. Waste will be separated into high-level and low-activity fractions. Low-activity waste (LAW) will be immobilized and disposed of onsite. High-level waste (HLW) will be immobilized for disposal in an offsite federal repository. The HLW will be safely stored onsite until shipment. 


\subsection{ESSENTIAL SAFETY OBJECTIVES}

This section contains the requirements and planning assumptions that pertain to the allowable limits on public, worker, and environmental exposure because of Hanford Site operations. Each of these items applies to the Site as a whole and therefore must be allocated to those projects that potentially can contribute to each item.

\section{Requirements:}

\section{Normal Operations:}

- Maximum individual dose from all pathways--The effective dose equivalent for any member of the public from all routine Hanford Site activities shall not exceed $25 \mathrm{mrem} / \mathrm{yr}$.

- Dose to native aquatic animal organisms from liquid discharges--Radioactive material in liquid waste discharged to natural waterways shall not cause an absorbed dose to native aquatic animal organisms that exceeds $1 \mathrm{rad} /$ day.

- Drinking water pathway--Radionuclide concentrations in DOE-operated public drinking water supplies shall not cause people consuming the water to receive an effective dose equivalent $>4 \mathrm{mrem} / \mathrm{yr}$. Hanford Site activities shall not cause private or public drinking water systems downstream of the facility discharge to exceed the radiological drinking water limits in 40 CFR 141, "National Primary Drinking Water Regulations Subpart A - General."

- Air pathway--The public dose limit at the location of maximum annual air concentration as a consequence of routine Hanford Site activities is $10 \mathrm{mrem} / \mathrm{yr}$.

- Public risk from operations--The risk to the population in the area of the Hanford Site for cancer fatalities that might result from operations shall not exceed $0.1 \%$ of the sum of all cancer fatality risks resulting from all other causes.

- Intruder protection (post-closure only)--The committed effective dose equivalents received by individuals who inadvertently may intrude onto the Hanford Site after the loss of active institutional control ( 100 years) shall not exceed $100 \mathrm{mrem} / \mathrm{yr}$ for continuous exposure or $500 \mathrm{mrem}$ for a single acute exposure.

- General population protection (post-closure only)--Total population exposure to Hanford Site activities (permanently disposed inventories) shall not exceed 500 person-rem/yr. 


\section{DOE/RL-97-55}

\section{Revision 0}

\section{Accident Conditions:}

- Public risk from accidents--The risk to an average individual in the vicinity of the Hanford Site for prompt fatalities that might result from accidents shall not exceed $0.1 \%$ of the sum of prompt fatalities resulting from other accidents to which members of the population generally are exposed.

\section{Planning Assumptions:}

- None.

\subsection{REFERENCES}

40 CFR 141, "National Primary Drinking Water Regulations Subpart A - General," Code of Federal Regulations, as amended.

60 FR 28680, "Programmatic Spent Nuclear Fuel Management and Idaho National Engineering Laboratory Environmental Restoration and Waste Management Program, Part III," Record of Decision, Federal Register, June 1, 1995.

61 FR 10736, "Management of Spent Nuclear Fuel from the K Basins at the Hanford Site, Richland, WA," Notice of Record of Decision, Federal Register, March 15, 1996.

Comprehensive Environmental Response, Compensation, and Liability Act of 1980 , 42 USC 9601 , et seq.

DOE, 1995, Life-Cycle Asset Management, DOE Order 430.1, U.S. Department of Energy, Washington, D.C.

DOE, 1996, Draft Hanford Remedial Action Environmental Impact Statement and Comprehensive Land Use Plan, DOE/EIS-0222D, U.S. Department of Energy, Washington, D.C.

DOE, 1997a, Final Waste Management Programmatic Environmental Impact Statement for Managing Treatment, Storage, and Disposal of Radioactive and Hazardous Waste, DOE/EIS-0200F, U.S. Department of Energy, Washington, D.C.

DOE, 1997b, Tank Waste Remediation System Environmental Impact Statement Record of Decision, Hanford Site, Richland, Washington, U.S. Department of Energy, Washington, D.C.

National Environmental Policy Act of 1969, 42 USC 4321, et seq.

Resource Conservation and Recovery Act of 1976, 42 USC 6901, et seq. 
DOE/RL-97-55

Revision 0

\subsection{SITE REQUIREMENTS AND PLANNING ASSUMPTIONS}

\subsection{INTRODUCTION}

The DOE will accomplish the Hanford Site mission through a number of prime contractors and subcontractors that have specific areas of responsibilities. A number of requirements apply universally to all activities conducted on the Hanford Site, regardless of the organization responsible for the activities. The activities of the contractors are specified in this document and summarized in Figure 3-1.

\subsection{INTERFACES}

\subsubsection{Site-Level Material and Waste Flow Interfaces (EM Complex Interfaces; Inputs and Outputs)}

This section contains the requirements and planning assumptions that define the boundaries and interfaces of the Hanford Site with other portions of the EM national waste management system. These requirements and planning assumptions specify the materials generated by other sites that the Hanford Site must deal with and the materials that the Hanford Site generates or contains that will be dispositioned offsite by other portions of the EM Complex. The responsibility for these material interfaces is assigned to specific projects and appears in the appropriate project specification in Section 4.0 (also see Tables 3-1 and 3-2).

\subsection{BANFORD SITE TECHNICAL LOGIC}

The Hanford Site technical logic is shown in Figure 3-2. These data reference the current planning assumptions based on the Hanford Site technical baseline. In many cases, this planning information is still the subject of pending NEPA decisions.

\subsection{REQUIREMENTS REFERENCES}

The DOE and contractor activities shall be conducted in accordance with the following requirements except where specific additions and deletions are noted in prime contract or subcontract documentation.

\section{General Site Requirements}

- Hanford Federal Facility Agreement and Consent Order (Ecology et al. 1996)

- DOE/RL-96-92, Hanford Strategic Plan (RL 1996a). 


\section{DOE/RL-97-55 \\ Revision 0}

Figure 3-1. Project Hanford Breakdown Structure. (2 sheets)

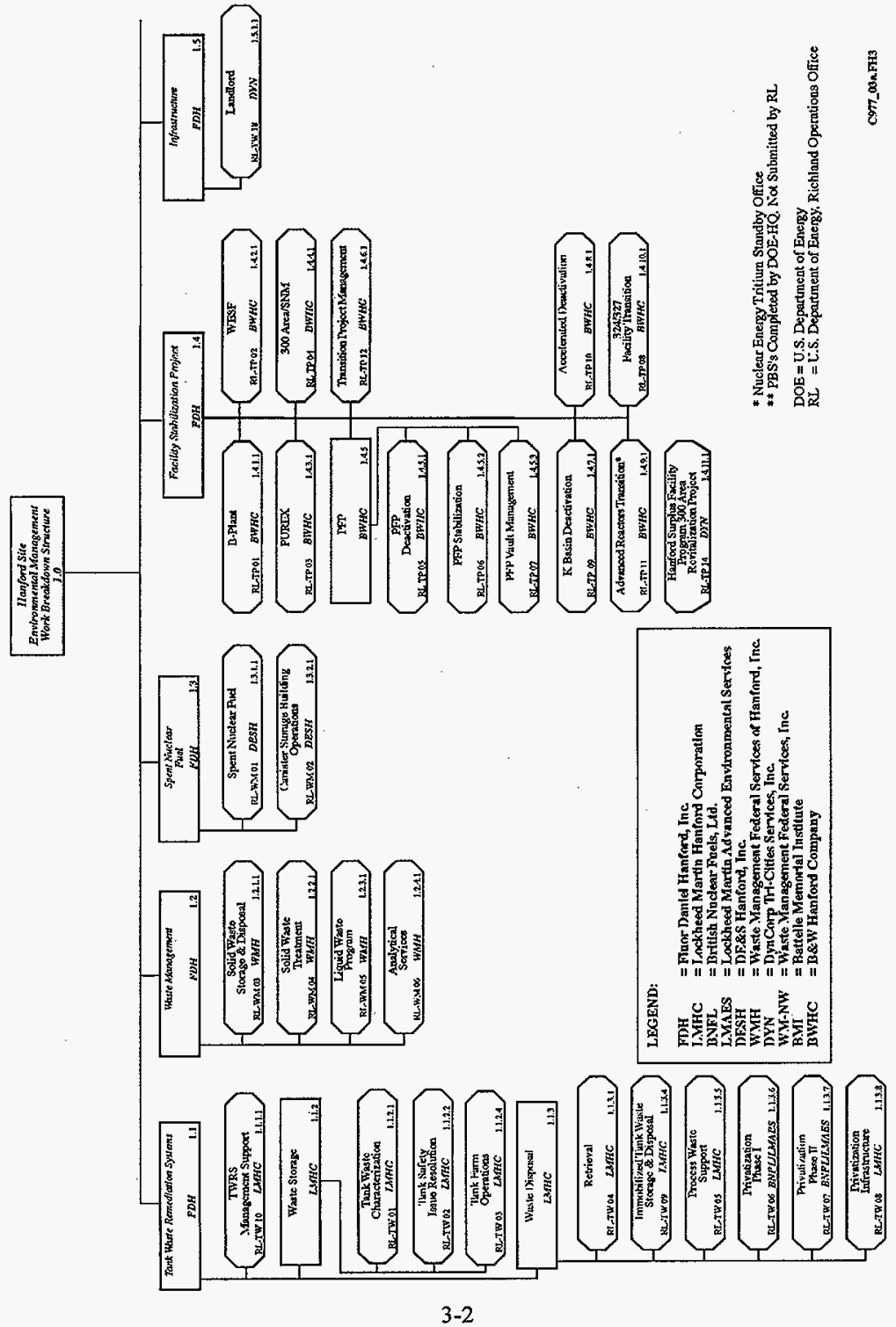




\section{DOE/RL-97-55 \\ Revision 0}

Figure 3-1. Project Hanford Breakdown Structure. (2 sheets)

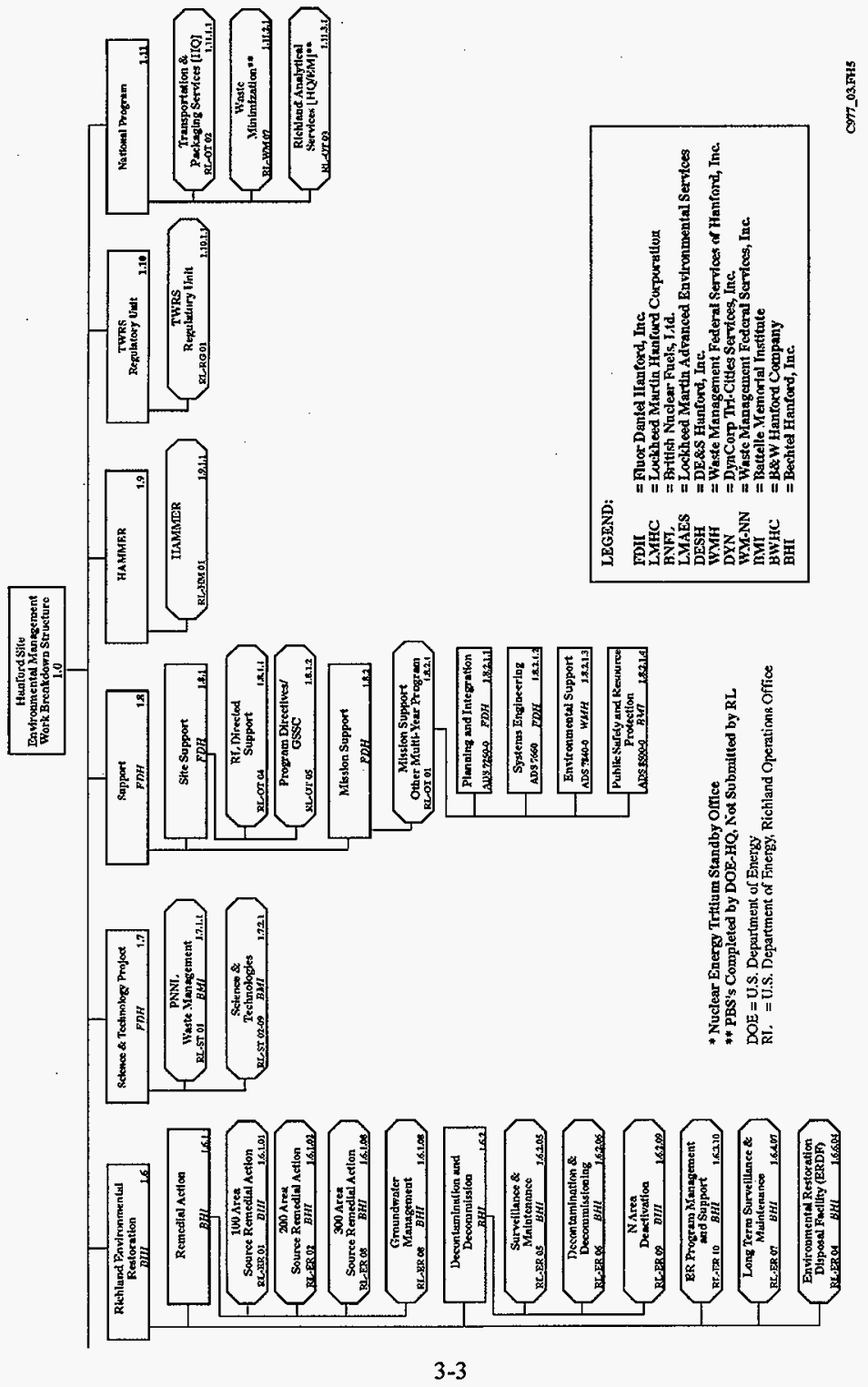




\section{Revision 0}

Table 3-1. Material and Waste External Inputs to Hanford Site.

\begin{tabular}{|l|l|l|}
\hline \multicolumn{1}{|c|}{ Item } & \multicolumn{1}{|c|}{ Requirement (source) } & \multicolumn{1}{|c|}{ Interface } \\
\hline $\begin{array}{l}\text { Naval } \\
\text { reactor } \\
\text { plants }\end{array}$ & $\begin{array}{l}\text { Decommissioned, defueled Naval submarine and cruiser reactor compartments } \\
\text { will be received for permanent land disposal in the 200 East Area. (EIS/RODs: } \\
\text { December 1984 and August 1986). (External to EM mission. Funded by } \\
\text { U.S. Department of Defense.) }\end{array}$ & $\begin{array}{l}\text { U.S. Department } \\
\text { of Defense, } \\
\text { U.S. Navy }\end{array}$ \\
\hline \multicolumn{1}{|c|}{ Planning assumptions } & \\
\hline $\begin{array}{l}\text { DOE } \\
\text { LLW }\end{array}$ & $\begin{array}{l}\text { The Hanford Site will provide LLW disposal services for offsite generators } \\
\text { designated by DOE-HQ. }\end{array}$ & $\begin{array}{l}\text { DOE offsite } \\
\text { generators }\end{array}$ \\
\hline $\begin{array}{l}\text { DOE } \\
\text { MLLW }\end{array}$ & $\begin{array}{l}\text { The Hanford Site will provide MLLW treatment and disposal services for offsite } \\
\text { generators designated by DOE-HQ. Treatment subject to regulator approval. }\end{array}$ & $\begin{array}{l}\text { DOE offsite } \\
\text { generators }\end{array}$ \\
\hline $\begin{array}{l}\text { DOE } \\
\text { TRU }\end{array}$ & $\begin{array}{l}\text { The Hanford Site will provide TRU storage and treatment services for offsite } \\
\text { generators designated by DOE-HQ. Regulated waste treatment subject to } \\
\text { regulator approval. }\end{array}$ & $\begin{array}{l}\text { DOE offsite } \\
\text { generators }\end{array}$ \\
$\begin{array}{ll}\text { DOE } & =\text { U.S. Department of Energy } \\
\text { DOE-HQ } & =\text { U.S. Department of Energy-Headquarters } \\
\text { EIS } & =\text { Environmental Impact Statement } \\
\text { EM } & =\text { U.S. Department of Energy, Office of Environmental Management } \\
\text { LLW } & =\text { low-level waste } \\
\text { MLLW } & \text { mixed low-level waste } \\
\text { ROD } & \text { Record of Decision } \\
\text { TRU } & =\text { transuranic }\end{array}$ \\
\end{tabular}

Table 3-2. Material and Waste External Outputs from Hanford Site.

\begin{tabular}{|l|l|l|}
\hline \multicolumn{1}{|c|}{ Item } & \multicolumn{1}{|c|}{ Requirement (source) } & Interface \\
\hline High-level waste & $\begin{array}{l}\text { High-level waste will be vitrified and shipped to the national repository for } \\
\text { disposal }\end{array}$ & OCRWM \\
\hline Plutonium & $\begin{array}{l}\text { Continuous interim storage at the Hanford Site Plutonium Finishing Plant } \\
\text { pending national policy on disposition }\end{array}$ & $\begin{array}{l}\text { To be } \\
\text { determined }\end{array}$ \\
\hline & \multicolumn{1}{|c|}{ Planning assumptions } & \\
\hline $\begin{array}{l}\text { Retrievable stored } \\
\text { transuranic }\end{array}$ & Transuranic waste will be shipped to WIPP for disposal. & EM WIPP \\
\hline Sodiurn-bonded fuel & After fiscal year 2000, sodium-bonded SNF will be shipped to INEEL. & INEEL \\
\hline SNE & SNF to be shipped offsite for final disposition at the national repository & $\begin{array}{l}\text { INEEL, } \\
\text { OCRWM }\end{array}$ \\
\hline
\end{tabular}

EM = U.S. Department of Energy, Office of Waste Management

INEEL = Idaho National Environmental and Engineering Laboratory

OCRWM = U.S. Department of Energy, Office of Civilian Radioactive Waste Management

SNF = spent nuclear fuel

WIPP $=$ Waste Isolation Pilot Plant 
DOE/RL-97-55

Revision 0

Figure 3-2. Hanford Site Technical Logic. (6 sheets)

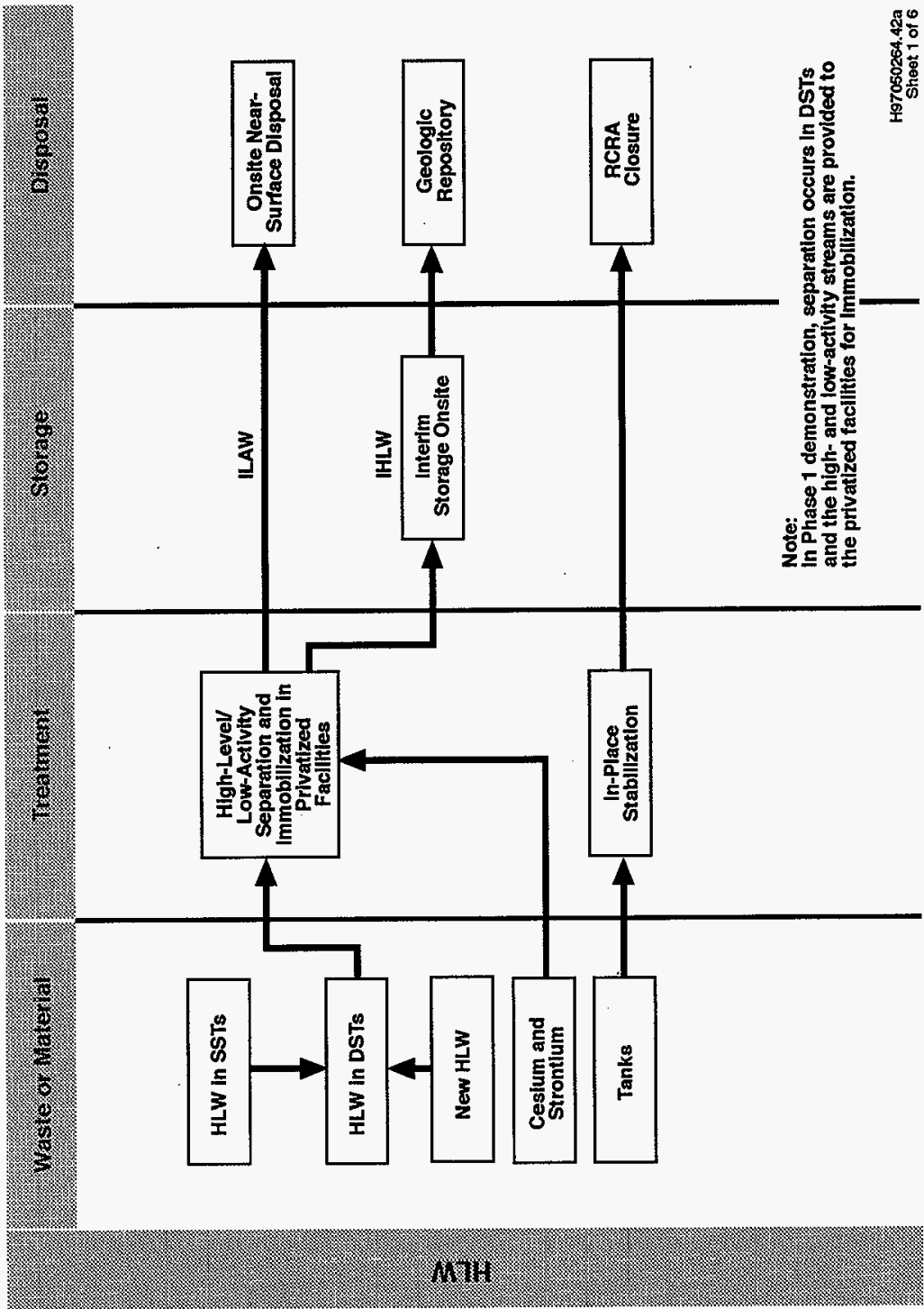


DOE/RL-97-55
Revision 0

Figure 3-2. Hanford Site Technical Logic. (6 sheets)

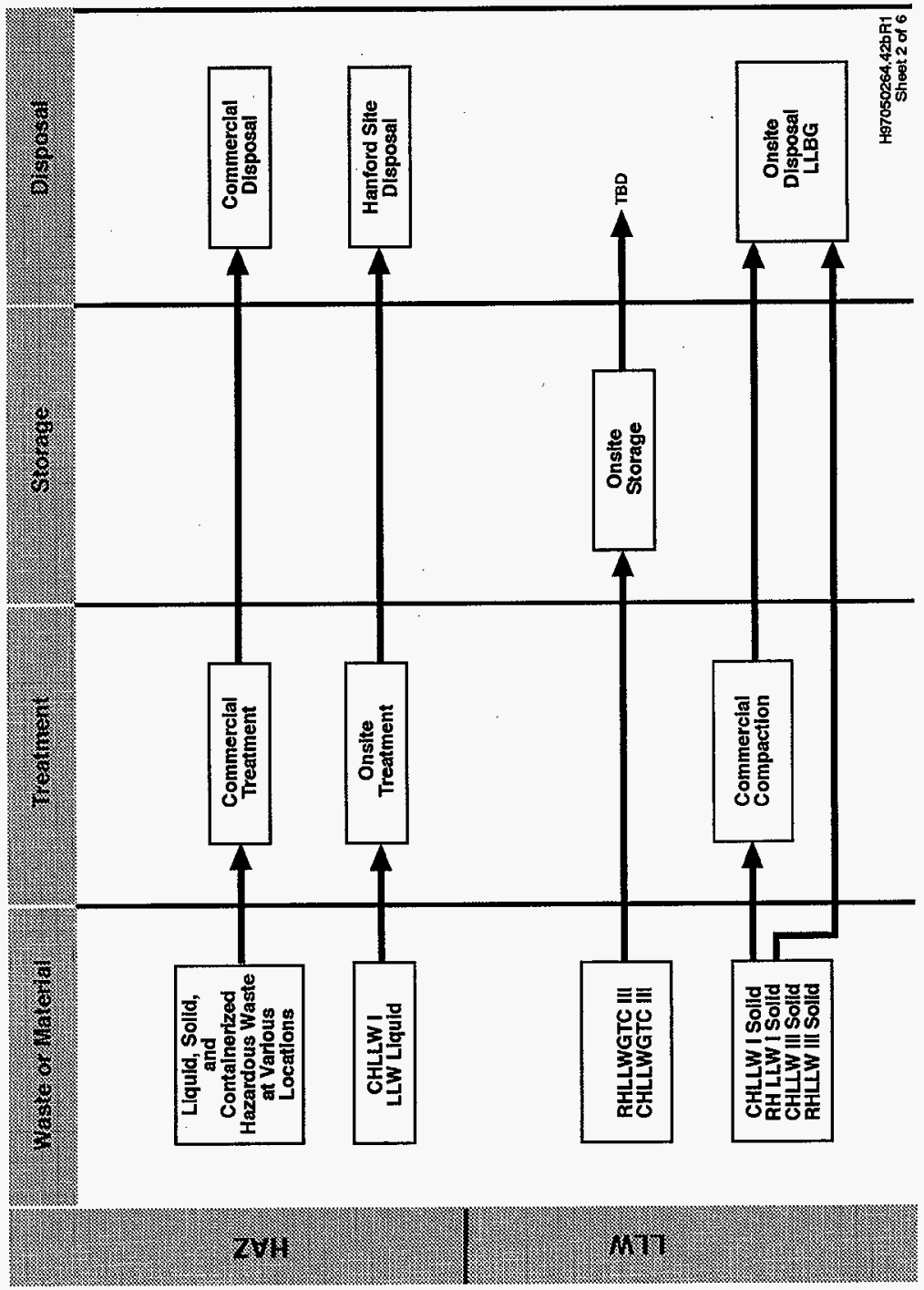


DOE/RL-97-55

Revision 0

Figure 3-2. Hanford Site Technical Logic. (6 sheets)

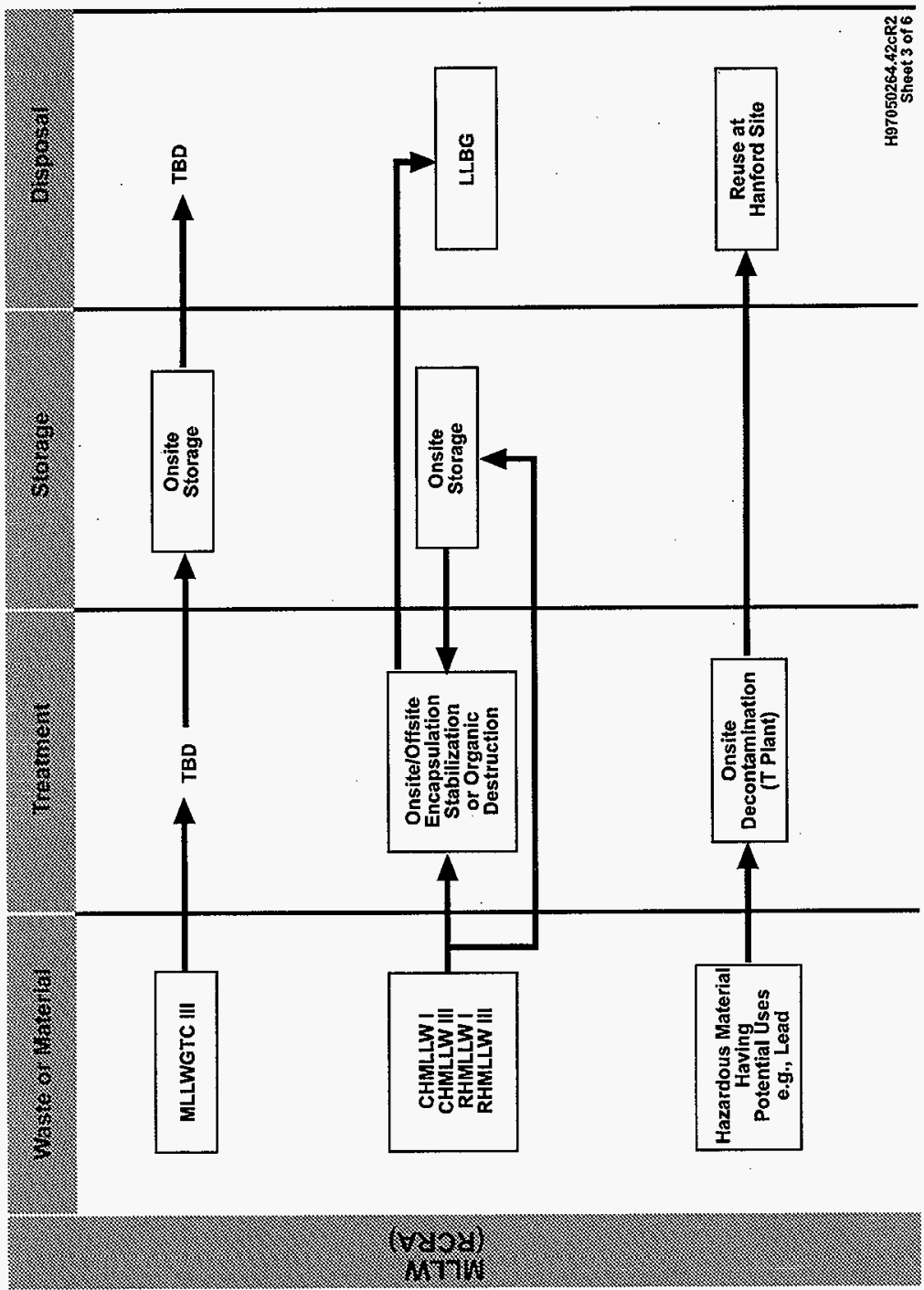




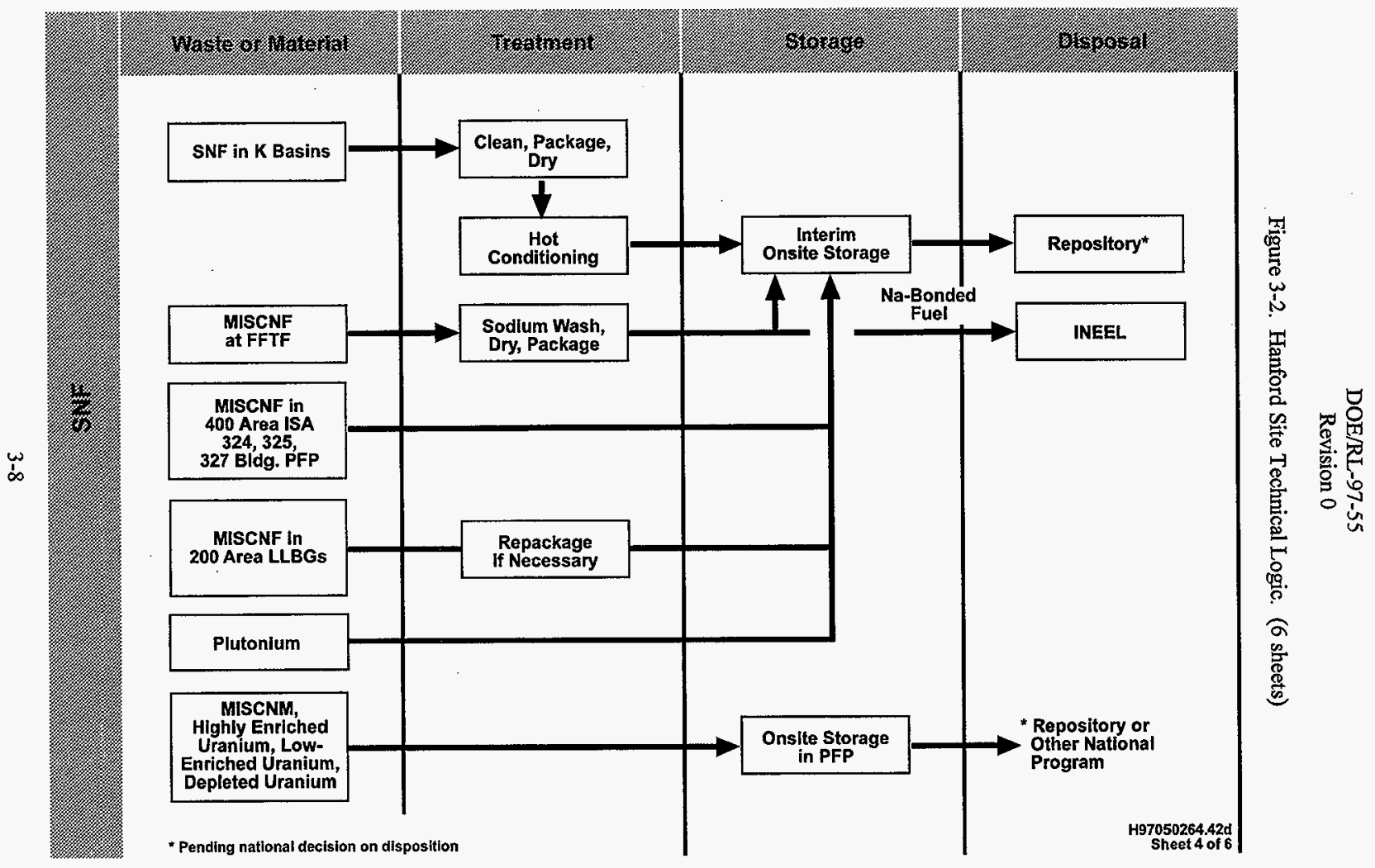


DOE/RL-97-55

Revision 0

Figure 3-2. Hanford Site Technical Logic. (6 sheets)

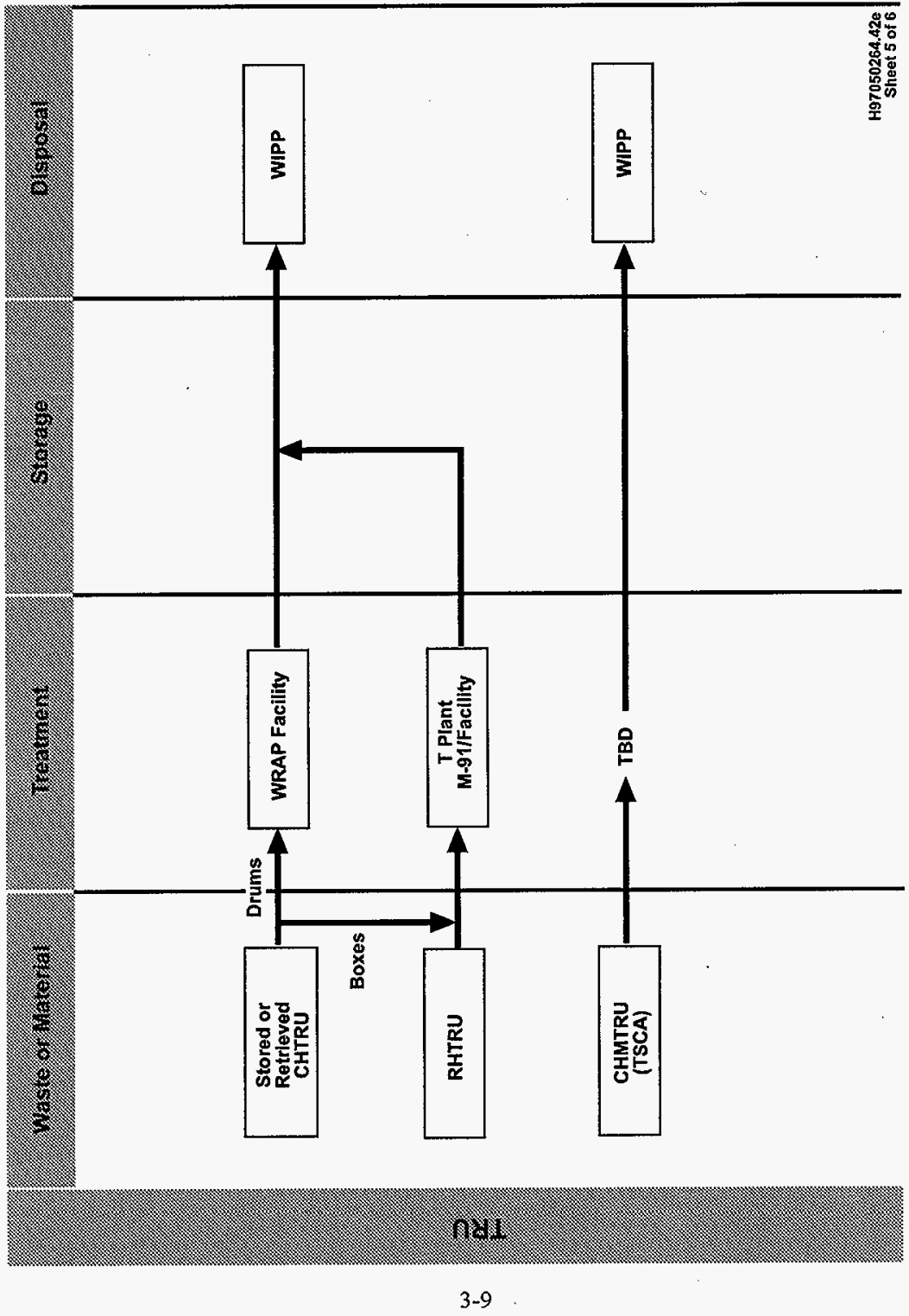




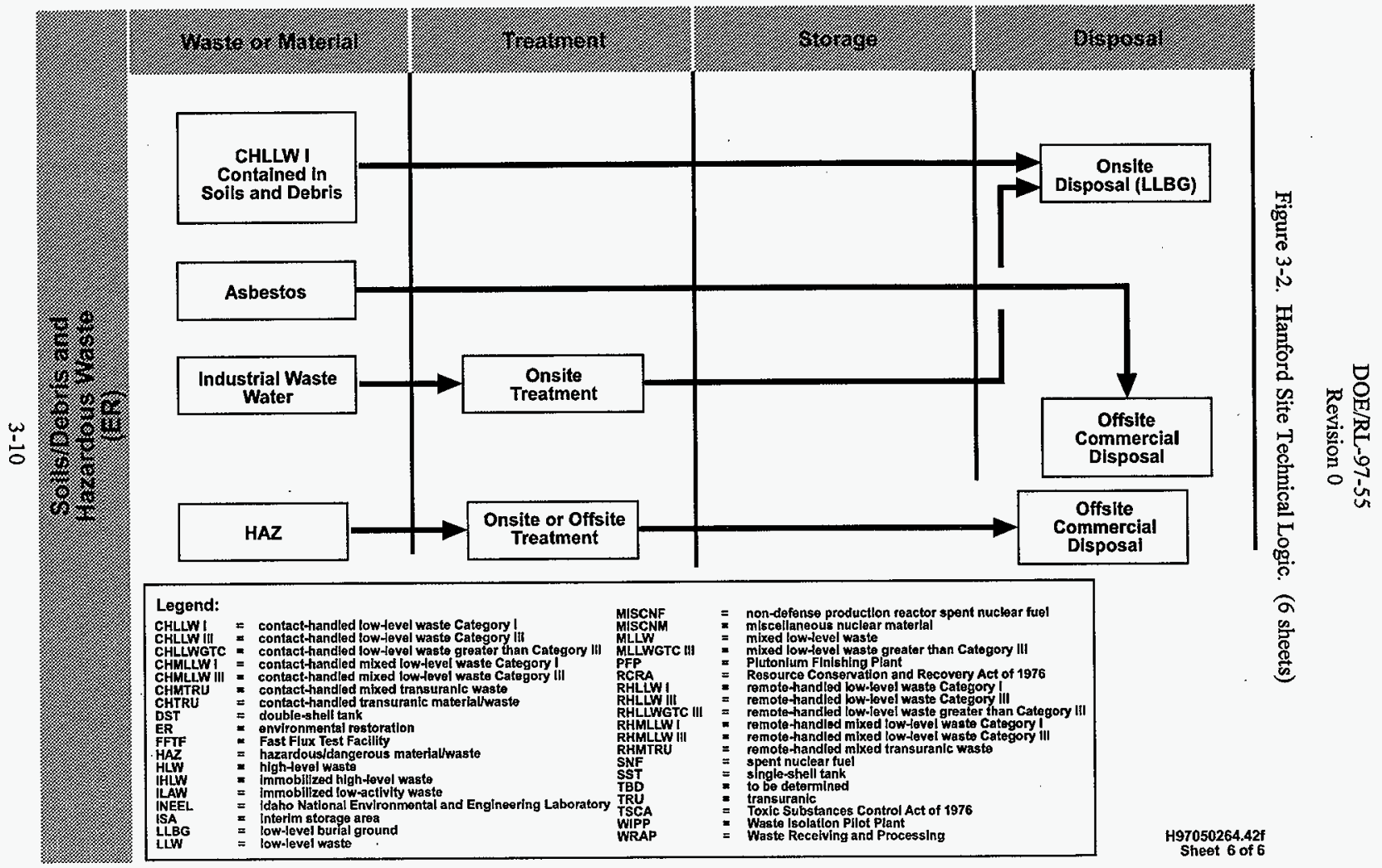


DOE/RL-97-55

Revision 0

\section{Laws and Regulations}

- Atomic Energy Act of 1954, Nuclear Waste Policy Act of 1982

- 42 USC 2286, Enabling Statute of the Defense Nuclear Facilities Defense Board

- NEPA

- Federal Water Pollution Control Act (Clean Water Act)

- Clean Air Act of 1955

- Safe Drinking Water Act of 1974

- CERCLA; WAC 173-340, "Model Toxics Control Act--Cleanup" (coordinated through the Tri-Party Agreement)

- RCRA; WAC 173-303, "Dangerous Waste Regulations" (coordinated through the Tri-Party Agreement)

- Occupational Safety and Health Administration, 10 CFR 20, "Standards for Protection Against Radiation;" 10 CFR 830, "Nuclear Safety Management;" WAC 246-220, "Radiation Protection--General Provisions;" WAC 246-221, "Radiation Protection Standards;" WAC 246-222, "Radiation Protection--Worker Rights"

- 10 CFR 71, "Packaging and Transportation of Radioactive Material;" DOE Order 5480.3, Safety Requirements for the Packaging Transportation of Hazardous Materials, Hazardous Substances, \& Hazardous Wastes (DOE 1985); 40 CFR 263, "Standards Applicable to Transporters of Hazardous Waste"

- 10 CFR 1021, "DOE NEPA Implementing Procedures"

- 40 CFR 1500-1508, "Council on Environmental Quality Regulations."

\section{DOE Departmental}

- DOE Order 5630.12A, Safeguards \& Security Inspection \& Assessment Program (DOE 1992a)

- DOE Order 5500.1B, Emergency Management System (DOE 1991a)

- DOE Order 5480.23, Nuclear Safety Analysis Reports (DOE 1992b)

- DOE Order 5420.2A, Radioactive Waste Management (DOE 1988) 
DOE/RL-97-55

Revision 0

- DOE Order 451.1A, National Environmental Policy Act Compliance Program (DOE 1997).

\section{RL Policies and Directives}

- RLID 430.1, Systems Engineering Criteria Document and Implementing Directive (RL 1996b)

- RLPD 430.1, Hanford Site Systems Engineering Policy (RL 1996c).

Environmental, Safety, and Health (ES\&H)

\section{Requirements:}

- DOE/EA-0210, Draft Environmental Assessment for Characterization of the Hanford Site Pursuant to the Nuclear Waste Policy Act of 1982 (Public Low 97-425) (DOE 1983)

- ERDA-1538, Waste Management Operations, Hanford Reservation, Richland, Washington: Final Environmental Statement (ERDA 1975)

- DOE/EIS-0046F, Final Environmental Impact Statement, Management of Commercially Generated Radioactive Waste (DOE 1980)

- 46 FR 26677, "Program of Research and Development for Management and Disposal of Commercially Generated Radioactive Wastes, Record of Decision."

Planning Assumptions:

- HRA-EIS (DOE 1996).

Other Requirements and Planning Assumptions:

Requirements:

- All other applicable federal, state, and local laws.

Planning Assumptions:

- None.

\subsection{MAJOR CONTRACTOR WORK SCOPE}

This section contains top-level requirements pertaining to the prime contractors at the Hanford Site. 
DOE/RL-97-55

Revision 0

\subsubsection{Fluor Daniel Hanford, Inc. (FDH) Contract Requirements Summary}

The Project Hanford Management Contract (PHMC) with FDH (DE-AC06-96RL13200), dated August 6, 1996 (RL 1996d), provides for the following summary requirements.

The PHMC Contractor shall be responsible for planning, managing, integrating, operating, and implementing a full range of Hanford Site programs, projects, and other activities as set forth in Section $\mathrm{C}$ of the contract. The PHMC Contractor shall be responsible for planning, integrating, managing, and executing the Hanford Site programs, projects, operations, and other activities as described in the Statement of Work, and detailed in the Performance Measures in Section J, Appendix D, of the contract.

The contractor shall furnish, or cause to be furnished, all personnel, facilities, equipment, material, supplies, and services (except as may be expressly set forth in the contract as furnished by the government), and otherwise do all things necessary for, or incident to, providing its best efforts to efficiently and effectively conduct all necessary work set forth in the Statement of Work. Because of the existence of the Hanford Environmental Health Foundation (HEHF), FDH is not responsible for health-related services provided by HEHF.

The contractor shall conduct business at the Hanford Site consistent with the values that flow from the Hanford Mission Plan (Garrison 1993) and the Hanford Strategic Plan (RL 1996a). The following values are the goals of this contract:

- Real progress on cleanup

- Systems managerially and financially in control

- Optimization of the Hanford Site infrastructure

- Technical integrity of an integrated Site baseline

- Meeting commitments and schedules

- Stability to the local economy.

The contractor shall integrate safety and environmental awareness into all activities, including those of subcontractors at all levels. Work must be accomplished in a manner that achieves high levels of quality while protecting the environment and the safety and health of workers and the public, and is in compliance with applicable requirements.

The contractor shall identify hazards, manage risks, identify and implement good management practices sitewide, and make continued improvements in ES\&H performance.

The contractor shall seek ways to streamline work processes by the use of necessary and sufficient processes to identify standards and requirements.

The period of performance for the work specified in Section $\mathrm{C}$ of the contract shall commence October 1,1996, and continue through September 30, 2001, unless sooner terminated as provided for in other provisions of the contract. The contract can be extended for up to an additional 5 years if the option provided for in the contract is exercised. 
3.5.1.1 Waste Minimization. The contractor shall minimize pollution and the generation of wastes by implementing the DOE-approved pollution prevention and waste minimization program at the Hanford Site. The requirements are identified in DOE/RL-91-31, Hanford Site Waste Minimization and Pollution Prevention Awareness Program Plan (RL 1997).

3.5.1.2 Management and Execution of Cleanup Mission. The PHMC team shall manage and execute the Hanford Site cleanup mission in accordance with the provisions of HNF-MP-003, Integrated Safety Management System (FDH 1997).

\subsubsection{Battelle Memorial Institute (BMI) Contract Requirements Summary}

In 1965, BMI assumed management and operation of the federal government laboratories at the Hanford Site. At that time, the research facility separated from Hanford Site operations and was renamed the Pacific Northwest Laboratory. Battelle invested $\$ 50$ million in private research facilities adjacent to the government laboratory. In 1996, the name of the laboratory was changed to Pacific Northwest National Laboratory (Pacific Northwest).

Initially, research at the laboratory focused on nuclear technology and the environmental and health effects of radiation. Today, staff at Pacific Northwest conduct a spectrum of projects and programs in energy, the environment, and the economy. These projects and programs have included helping the DOE establish the first Atmospheric Radiation Measurement site to obtain data related to global environmental change; developing and transferring to industry a thermochemical technology that converts organic wastes to methane and carbon dioxide; and discovering ancient microbial organisms that hold potential for remediating contaminated soils deep within the earth.

The core mission of Pacific Northwest is to deliver environmental science and technology in the service of not only the Hanford Site, but also the nation and humanity. Through basic research, Pacific Northwest creates fundamental knowledge of natural, engineered, and social systems for effective environmental technology and sound public policy. Pacific Northwest also solves legacy environmental problems by delivering technologies that remediate existing environmental hazards, addressing today's environmental needs with technologies that prevent pollution and minimize waste, and laying the technical foundation for tomorrow's inherently clean energy and industrial processes. Pacific Northwest applies capabilities to meet selected national security, energy, and human health needs; strengthen the U.S. economy; and support the education of future scientists and engineers.

\subsubsection{Operating and Management Services - Statement of Work - Summary.}

NOTE: The following paragraphs summarize excerpts from the Pacific Northwest prime operating contract with the DOE. These excerpts are intended to provide an overview of responsibilities and expectations. All contractual matters will be administered and dispositioned in accordance with the prime contract document and not this summary. 


\section{Revision 0}

The services to be performed include, but are not necessarily limited to, the following.

- The conduct of basic research in the fields of energy and basic science involving fundamental studies and theoretical, computational, and experimental investigations, which are of interest to DOE's program(s).

- The conduct of applied research, development, engineering, production support, and field program/project management, which are of programmatic interest to the DOE. This will include the development of programs to support the Environmental and Molecular Sciences Laboratory to be an extension of the current environmental mission at the Hanford Site.

- The performance of services that the contractor is particularly qualified to perform for $\mathrm{RL}$ or other contractors of the DOE at the Hanford Site.

- The conduct of supporting demographic, environmental, institutional, legal, policy, and socioeconomic research and studies (including the use of social, behavioral, and political science resources in the contractor's Pacific Northwest Division).

- The initiation of such recommendations to the DOE for the modification, improvement, alteration, or repair of existing facilities or construction of new facilities as the contractor considers essential for the continued or safe operation of Pacific Northwest or necessary to allow realization of benefits and advantages attained in the course of work.

- The conduct of engineering and scoping for construction for all projects of the nature previously described above and the provision of liaison or management services with architect-engineer and construction contractors that may be engaged by the contractor or the DOE for work on such projects.

- Participation in cooperative educational programs with universities and colleges.

\subsubsection{Related Services.}

- In addition, the contractor shall perform other services incidental or related to services described previously or to the programs of the DOE as the DOE and the contractor shall agree from time to time.

- The contractor will render services to other cost-type contractors of DOE and to other federal agencies. The contractor will receive transfers of funds therefore from such federal agencies and other cost-type contractors to the extent that such transfer is required from time to time by the $\mathrm{DOE}$. 
DOE/RL-97-55

Revision 0

\subsubsection{General.}

- The contractor shall perform the maintenance work necessary for the efficient and legally compliant operations of the facilities.

- The contractor shall cooperate with industrial organizations to assist in increasing industrial competence in and contributions to applications of science and technology. Such cooperation may include an early transfer of information to industry.

- The contractor shall undertake activities pertaining to the dissemination of information relating to energy in general and laboratory programs in particular.

- The contractor shall, when directed by the DOE, and may, but only when authorized by the DOE, enter into subcontracts for the performance of any part of the previously described work.

\subsubsection{Special Contract Requirements. Specific contract requirements are as follows.}

3.5.2.4.1 Use of Facilities for Contractor's Own Account. The contractor may use DOE-assigned facilities and other government-owned property in its custody under this contract to conduct research and development activities for its own account, to the extent and in accordance with such terms and conditions as the DOE and the contractor may agree to from time to time as set forth in Contract DE-AC06-76RL01831 (AEC 1964). Except as incorporated by reference in the aforementioned contract, the terms and conditions of this contract shall not apply to such research and development activities.

3.5.2.4.2 Source and Special Nuclear Materials (SNM). The contractor shall comply with all applicable regulations and instructions of the DOE relative to the control of and accounting for source and SNM (as these terms are defined in the Atomic Energy Act of 1954). The contractor shall take all reasonable steps and precautions to protect such materials against theft and misappropriation and to minimize all losses of such materials.

3.5.2.4.3 DOE Directives. Effective October 1, 1992, DOE Directives, RL Implementing Procedures (RLIP), RL Implementing Directives (RLID), or DOE and RL successor directives, which are transmitted to the contractor by the Contracting Officer, shall be implemented.

3.5.2.4.4 Environment. The contractor shall perform the work in a manner that is protective of the environment and shall comply with all applicable environmental laws, regulations, and other requirements such as DOE Orders. Additionally, the contractor shall comply with the following: (1) Executive Order 12780 of October 31, 1991, "Federal Agency Recycling and the Council on Federal Recycling and Procurement Policy," and (2) 40 CFR 247, "Comprehensive Procurement Guideline for Products Containing Recovered Materials." If the contractor fails to comply with said laws, regulations, and other requirements, the Contracting Officer may issue an order stopping all or any part of the work. 
DOE/RL-97-55

Revision 0

3.5.2.4.5 Project Control System. The contractor shall establish, maintain, and use a system to manage and control all projects. This system shall meet the requirements set forth in the contract and described in draft DOE Notice 4700, Project Control System Guidelines, dated February 14, 1992, or as definitized.

3.5.2.4.6 Financial Management System. The contractor shall maintain and administer a financial management system that includes all manual and automated systems for budget formulation and execution, currently existing integrated accounting system and other systems or subsystems used for recording and classifying financial data and reporting financial management information.

3.5.2.4.7 Whistle Blower Protection for Contractor Employees. The contractor shall comply with the requirements of 10 CFR 708, "Contractor Employee Protection Program."

3.5.2.4.8 Facilities Management. The government shall provide the contractor with Site development guidance for the facilities and lands for which the contractor is responsible. Based on this guidance, the contractor shall prepare, and maintain through annual updates, a long-range site development plan (plan) to reflect those actions necessary to keep the development of these facilities current with the needs of the government and allow the contractor to successfully accomplish the work required under the contract. In developing this plan, the contractor shall follow the procedural guidance set forth in DOE Order 4320.1B, Site Development Planning (DOE 1991b). The contractor shall use the plan to manage and control the development of facilities and lands.

Maintenance Management--In its management of property on the Site, the contractor shall comply with the provisions of DOE Order 4330.4B, Maintenance Management Program (DOE 1994). This Directive requires the establishment and execution of a maintenance management program for all property under the control of the contractor. The contractor shall maintain property for which it is accountable in a manner that promotes operational safety, environmental protection and compliance, property preservation, and cost effectiveness. The contractor shall maintain property to enhance the ability of the property, throughout its life, to meet the requirements for which it was designed. This includes periodic examination of the property to determine any deterioration or technical obsolescence that may threaten performance or safety.

3.5.2.4.9 Non-Liability with Respect to Cost Accounting Standards. The contractor shall not be liable to the government for any increased costs, or interest thereon, resulting from any failure of the contractor, with respect to activities carried on at the site of the work, to comply with cost accounting standards, provided the contractor is in compliance with DOE-specified accounting practices and procedures. The contractor also shall not be liable to the government for any increased costs or interest of a subcontractor that fails to comply with applicable cost accounting standards, provided the contractor includes in each covered subcontract a clause making the subcontractor liable for any increase costs or interest thereon resulting from any failure of the subcontractor to comply with prescribed standards of disclosure practices. 
DOE/RL-97-55

Revision 0

\subsubsection{Bechtel Hanford, Inc., Contract Requirements Summary}

The Environmental Restoration Contractor (ERC) shall be responsible for planning, managing, executing, and integrating the Environmental Restoration (ER) Program at the Hanford Site. The ERC shall perform or subcontract program activities as identified in the Statement of Work. These program activities include, but are not limited to, characterization and remediation of past-practice waste sites, technology development program integration, application of innovative remediation technologies, $N$ Reactor deactivation, and $D \& D$ activities. A current list of facilities for D\&D is included in Section $J$, Attachment 2, Appendix 5, in the contract.

The ERC shall provide the technical and management staff to plan, procedure, manage, perform, and integrate the full range of activities required to accomplish the environmental remediation of the Hanford Site. This includes those activities formerly performed by the U.S. Army Corps of Engineers (USACE) under an interagency agreement between RL and the Corps North Pacific Division. The ERC shall be responsible for performing the work consistent with all applicable federal, state, and local laws; regulations; DOE Orders, directives, and Secretary of Energy Notices.

The ERC shall integrate all contractor and subcontractor activities and coordinate as necessary with the USACE to accomplish all requirements in applicable laws, regulations, the Tri-Party Agreement, and the ER Project. The ER Project milestones are included in the most current negotiated revision of the Tri-Party Agreement. The quality and timeliness of deliverables shall satisfy all requirements of laws, regulations, the Tri-Party Agreement, and any approved Tri-Party Agreement changes.

The ERC shall provide leadership in the application of innovative technologies to remediate the Hanford Site. In particular, the ERC must be cognizant of work being performed to remediate other DOE sites as well as environmental remediation and D\&D technologies being applied in the commercial sector. The ERC must maintain cognizance of activities within DOE's Research, Development, and Demonstration Technology Evaluation Program, and shall be expected to identify opportunities for development and application of those technologies in the ER Project at the Hanford Site.

\subsubsection{Tank Waste Remediation System (TWRS) Privatization Contract Requirements Summary}

TWRS Privatization Contract Requirements

British Nuclear Fuels Ltd. (BNFL) TWRS Privatization

Contract No. DE-AC06-96RL13308, Part I (RL 1996e)

Lockheed Martin Advanced Environmental Services TWRS Privatization

Contract No. DE-AC06-96RL13309 (RL 1996) 
The $R \mathbf{L}$ is acquiring Hanford Site tank waste treatment services at a demonstration scale using privatized facilities--privately developed, financed, constructed, owned, operated, and deactivated. The two parts of this procurement are Part A and Part B.

Part A is a 20-month period to establish the technical, operational, regulatory, and financial elements required by privatized facilities to provide waste treatment services at fixed unit prices. The 20 -month period is divided into a $16-$ month period for the contractor to provide Part A deliverables and a 4-month period during which the Part A deliverables will be reviewed and the DOE will determine whether to authorize the contractor to perform Part B.

Part B is a 10- to 14-year period to provide waste treatment services in privatized facilities at fixed unit prices. Three LAW feed envelopes will be provided in Part B. If the Contract includes HLW services, one HLW feed envelope also will be provided. Once contractor waste treatment services are no longer required, the DOE will direct the contractor to deactivate all contractor-provided facilities. The DOE will order a minimum quantity of waste treatment services during Part $\mathrm{B}$ and may provide additional orders up to a maximum quantity of waste treatment services.

Primary objectives for this procurement are to demonstrate the technical and business viability of using privatized facilities for waste treatment; define and maintain required levels of radiological, nuclear, process, and occupational safety; maintain environmental protection and compliance; and, substantially reduce life-cycle cost and the time required to treat Hanford Site tank waste.

\subsection{REFERENCES}

10 CFR 20, "Standards for Protection Against Radiation," Code of Federal Regulations, as amended.

10 CFR 71, "Packaging and Transportation of Radioactive Material," Code of Federal Regulations, as amended.

10 CFR 708, "Contractor Employee Protection Program," Code of Federal Regulations, as amended.

10 CFR 830, "Nuclear Safety Management," Code of Federal Regulations, as amended.

10 CFR 1021, "DOE NEPA Implementing Procedures," Code of Federal Regulations, as amended.

40 CFR 247, "Comprehensive Procurement Guideline for Products Containing Recovered Materials," Code of Federal Regulations, as amended.

40 CFR 263, "Standards Applicable to Transporters of Hazardous Waste," Code of Federal Regulations, as amended. 
DOE/RL-97-55

Revision 0

40 CFR 1500-1508, "Council on Environmental Quality Regulations," Code of Federal Regulations, as amended.

46 FR 26677, "Program of Research and Development for Management and Disposal of Commercially Generated Radioactive Wastes, Record of Decision," Federal Register, May 14, 1981.

AEC, 1964, Use Permit, Contract DE-AC06-76RL01831, Battelle Memorial Institute, Pacific Northwest Laboratory, No. AT(45-1)-1831, signed December 30 by B. D. Thomas of Battelle Memorial Institute and by the Contracting Officer for the U.S. Atomic Energy Commission, Richland Washington.

Atomic Energy Act of 1954, 42 USC 2011, et seq.

Clean Air Act of 1955, as amended, 42 USC 7401, et seq.

Comprehensive Environmental Response, Compensation, and Liability Act of 1980 , 42 USC 9601 et seq.

DOE, 1980, Final Environmental Impact Statement, Management of Commercially Generated Radioactive Waste, DOE/EIS-0046F, U.S. Department of Energy, Washington, D.C.

DOE, 1983, Draft Environmental Assessment for Characterization of the Hanford Site Pursuant to the Nuclear Waste Policy Act of 1982 (Public Law 97-425), DOE/EA-0210, U.S. Department of Energy, Washington, D.C.

DOE, 1985, Safety Requirements for the Packaging Transportation of Hazardous Materials, Hazardous Substances, \& Hazardous Wastes, DOE Order 5480.3, U.S. Department of Energy, Washington, D.C.

DOE, 1988, Radioactive Waste Management, DOE Order 5820.2A, U.S. Department of Energy, Washington, D.C.

DOE, 1991a, Emergency Management System, DOE Order 5500.1B, U.S. Department of Energy, Washington, D.C.

DOE, 1991b, Site Development Planning, DOE Order 4320.1B, U.S. Department of Energy, Washington, D.C.

DOE, 1992a, Safeguards \& Security Inspection \& Assessment Program, DOE Order 5630.12A, U.S. Department of Energy, Washington, D.C.

DOE, 1992b, Nuclear Safety Analysis Reports, DOE Order 5480.23, U.S. Department of Energy, Washington, D.C. 
DOE/RL-97-55

Revision 0

DOE, 1994, Maintenance Management Program, DOE Order 4330.4B, U.S. Department of Energy, Washington, D.C.

DOE, 1995, Spent Fuel Management and Idaho National Engineering Laboratory Environmental Restoration and Waste Management Programs Final Environmental Impact Statement, DOE/EIS-0203F, U.S. Department of Energy, Washington, D.C.

DOE, 1996, Draft Hanford Remedial Action Environmental Impact Statement and Comprehensive Land Use Plan, DOE/EIS-0222D, U.S. Department of Energy, Washington, D.C.

DOE, 1997a, National Environmental Policy Act Compliance Program, DOE Order 451.1A, U.S. Department of Energy, Washington, D.C.

DOE, 1997b, Tank Waste Remediation System Environmental Impact Statement Record of Decision, Hanford Site, Richland, Washington, U.S. Department of Energy, Washington, D.C.

Ecology, EPA, and DOE, 1996, Hanford Federal Facility Agreement and Consent Order, as amended, Washington State Department of Ecology, U.S. Environmental Protection Agency, and U.S. Department of Energy, Olympia, Washington.

Enabling Statute of the Defense Nuclear Facilities Defense Board, 42 USC 2286, et. seq.

ERDA, 1975, Waste Management Operations, Hanford Reservation, Richland, Washington: Final Environmental Statement, ERDA-1538, Vol. 1, U.S. Energy Research \& Development Administration, Washington, D.C.

Executive Order 12780, "Federal Agency Recycling and the Council on Federal Recycling and Procurement Policy," 56 FR 56289, October 31, 1991.

FDH, 1997, Integrated Safety Management System, HNF-MP-003, Fluor Daniel Hanford, Inc., Richland, Washington.

Federal Water Pollution Control Act (Clean Water Act), 33 USC 1251, et seq.

Garrison, H. L., 1993, Hanford Mission Plan, Vol. 1, "Site Guidance," DOE/RL-93-08, U.S. Department of Energy, Richland Operations Office, Richland, Washington.

National Environmental Policy Act of 1969, 42 USC 4321, et seq.

Nuclear Waste Policy Act of 1982, 42 USC 40101, et seq.

Resource Conservation and Recovery Act of 1976, 42 USC 6901, et seq. 
DOE/RL-97-55

Revision 0

RL, 1996a, Hanford Strategic Plan, DOE/RL-96-92, Rev. 0, U.S. Department of Energy,

Richland Operations Office, Richland, Washington.

RL, 1996b, Systems Engineering Criteria Document and Implementing Directive, RLID 430.1,

U.S. Department of Energy, Richland Operations Office, Richland, Washington.

RL, 1996c, Hanford Site Systems Engineering Policy, RLPD 430.1, U.S. Department of Energy, Richland Operations Office, Richland, Washington.

RL, 1996d, Project Hanford Management Contract with Fluor Daniel Hanford, Inc.

(DE-AC06-96RL13200), dated July 3, U.S. Department of Energy, Richland Operations

Office, Richland, Washington.

RL, 1996e, British Nuclear Fuels Ltd. TWRS Privatization Contract No. DE-AC06-96RL13308,

Part 1, U.S. Department of Energy, Richland Operations Office, Richland, Washington.

RL, 1997, Hanford Site Waste Minimization and Pollution Prevention Awareness Program Plan, DOE/RL-91-31, U.S. Department of Energy, Richland Operations Office, Richland, Washington.

Safe Drinking Water Act of 1974, 42 USC 300f, et seq.

WAC 173-303, "Dangerous Waste Regulations," Washington Administration Code, as amended.

WAC 173-340, "Model Toxics Control Act--Cleanup," Washington Administration Code, as amended.

WAC 246-220, "Radiation Protection--General Provisions," Washington Administration Code, as amended.

WAC 246-221, "Radiation Protection Standards," Washington Administration Code, as amended.

WAC 246-222, "Radiation Protection--Worker Rights," Washington Administration Code, as amended.

\subsection{BIBLIOGRAPHY}

60 FR 28680, "Programmatic Spent Nuclear Fuel Management and Idaho National Engineering Laboratory Environmental Restoration and Waste Management Programs, Part III," Record of Decision, Federal Register, June 1, 1995.

DOE, 1997, Final Waste Management Programmatic Environmental Impact Statement for Managing Treatment, Storage, and Disposal of Radioactive and Hazardous Waste, DOE/EIS-0200F, U.S. Department of Energy, Washington, D.C. 
DOE/RL-97-55

Revision 0

May 29, 1998

\subsection{PROJECT SPECIFICATIONS}

\subsection{INTRODUCTION}

This section contains the specifications for each technical project at the Hanford Site. Projects are identified consistent with the Project Hanford Breakdown Structure in Figure 3-1. This section contains descriptive material, requirements, and planning assumptions that are specific to the individual projects. The requirements and planning assumptions contained in Section 4.0 are in addition to the requirements and planning assumptions contained in Sections 2.0 and 3.0. The material in Sections 2.0 and 3.0 apply to all activities at the Hanford Site and/or all activities under a specific prime contract.

\subsection{FDH CONTRACT REQUIREMENTS}

The contractor (FDH) shall be responsible for the accomplishment of all work described in the PHIMC.

The contractor is expected to subcontract the work of the Hanford Site projects (except where otherwise noted) to firms considered among the "best in class" for the work involved in that project.

The contractor shall organize to optimally manage and support the Hanford Site projects contained in the PHMC (see Section J, Appendix J of the contract) and to provide direct support to individual RL managers in the accomplishment of project completion. Section 4.2 covers projects managed by FDH and the following subcontractors: Lockheed Martin Hanford Corporation; Waste Management Federal Services of Hanford, Inc.; B\&W Hanford Company; DynCorp Tri-Cities Services, Inc; and DE\&S Hanford, Inc. The contractual responsibilities are shown against the Project Hanford Breakdown Structure in Figure 3-1. 
DOE/RL-97-55

Revision 0

May 29, 1998

Tank Waste Remediation System Summary Description

Concurrence: Original signed by D. D. Wodrich D. D. Wodrich, Senior Technical Advisor, Office of Assistant Manager for Tank Waste Remediation System, U.S. Department of Energy, Richland Operations Office
Approved by: Orig signed by M. A. Hunemuller

J. E. Kinzer, Assistant Manager, Office of Assistant Manager for Tank Waste Remediation System, U.S. Department of Energy, Richland Operations Office 
DOE/RL-97-55

Revision 0

May 29, 1998

\subsubsection{TWRS Summary Description}

The TWRS Project mission is to manage and immobilize for disposal the Hanford Site radioactive tank waste in a safe, environmentally sound, and cost-effective manner. The scope includes the activities needed to (1) resolve safety issues; (2) operate, maintain, and upgrade the tank farms and supporting infrastructure; (3) construct, operate, and maintain facilities as necessary; (4) characterize, retrieve, pretreat, and immobilize the waste for disposal and tank farm closure; (5) provide for disposition of cesium (Cs)/strontium ( $\mathrm{Sr}$ ) capsule contents; (6) provide disposal of immobilized low-activity waste (ILAW) onsite; (7) provide interim storage of immobilized high-level waste (IHLW) until it is shipped to the national repository; and (8) provide for closure and D\&D of TWRS facilities and initiation of post-closure monitoring. The TWRS Project is responsible for closure of assigned operable units.

To accomplish the TWRS Project mission, a phased approach is being implemented in accordance with the Tank Waste Remediation System Environmental Impact Statement Record of Decision, Hanford Site, Richland, Washington (DOE 1997a). The TWRS Project consists of the following ten projects (see Figure 3-1). The numbers following the project titles reflect the project baseline summary (PBS) number.

- Tank Waste Characterization Project (RL-TW01)

- Tank Safety Issue Resolution Project (RL-TW02)

- Tank Farm Operations Project (RL-TW03)

- Retrieval Project (RL-TW04)

- Process Waste Support Project (RL-TW05)

- Privatization Phase I Project (Private Contractors [RL-TW06], see Section 4.5)

- Privatization Phase II Project (Private Contractors [RL-TW07], see Section 4.6)

- Privatization Infrastructure Project (RL-TW08)

- Immobilized Tank Waste Storage \& Disposal Project (RL-TW09)

- TWRS Management Support Project (RL-TW10).

\section{TWRS Technical Logic}

Figure 4-1 presents the material flow/logic for the entire TWRS Project. Figure 4-2 (Powell 1998) shows the TWRS Program Logic. This figure will be referred to in the individual TWRS Project sections.

4.2.1.1 Tank Waste Characterization Project. This section is based on the TWRS baseline as of June 1, 1998. Following selection of the privatization contractor, this information will be updated to reflect the contractor's process and interface with the rest of the TWRS process.

\subsection{Project Description Summary. The purpose of the Tank Waste}

Characterization Project is to characterize the radioactive $\mathrm{HLW}$ at the Hanford Site in accordance with data quality objectives established by the projects responsible for the safe storage, safety issue resolution, retrieval, and treatment/immobilization of the tank waste. This waste is stored in large, underground, radioactive waste storage DSTs, SSTs, double-contained receiver tanks, 
Figure 4-1. Tank Waste Remediation System Material Flow/Logic.

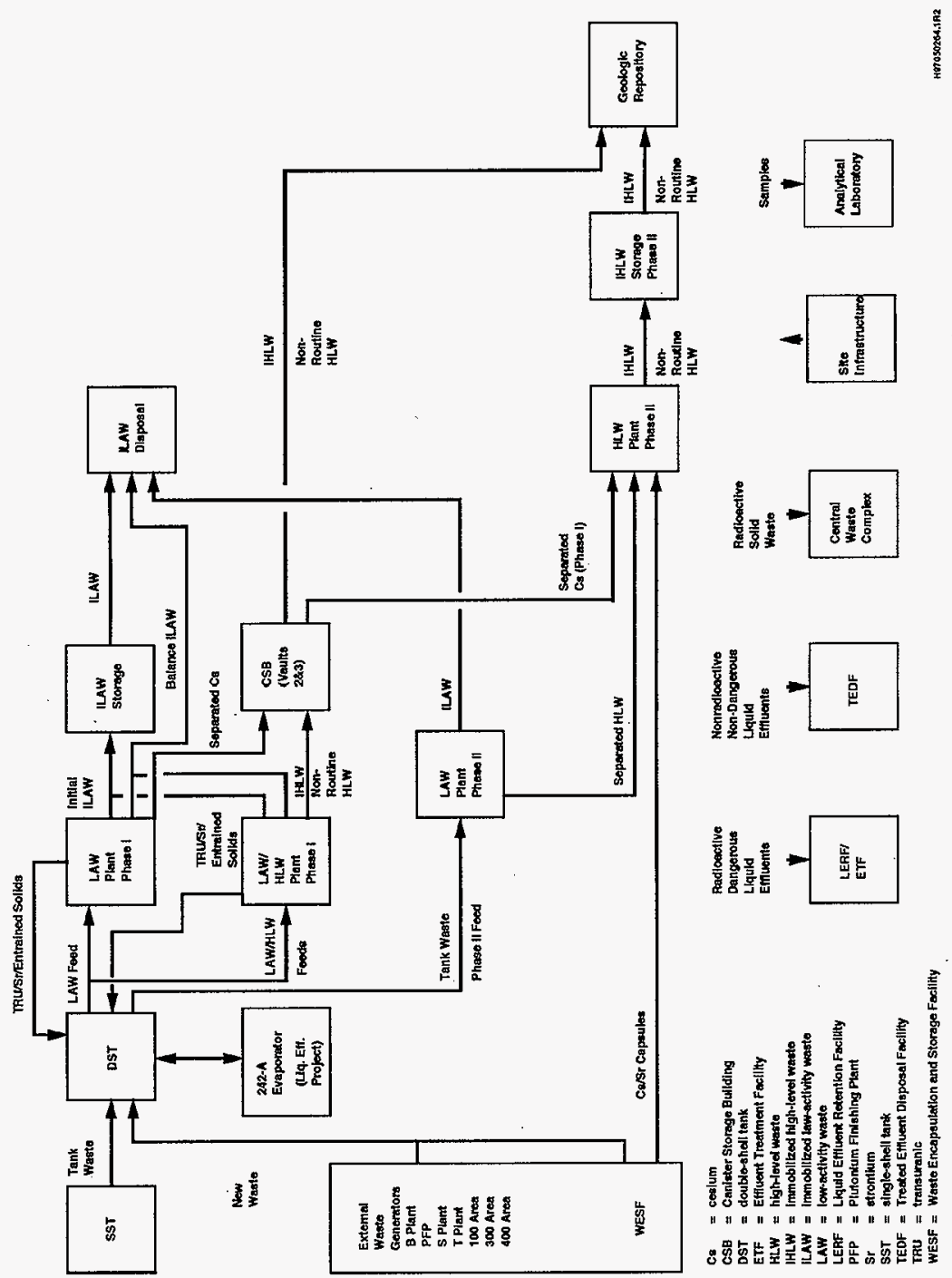


Figure 4-2. Tank Waste

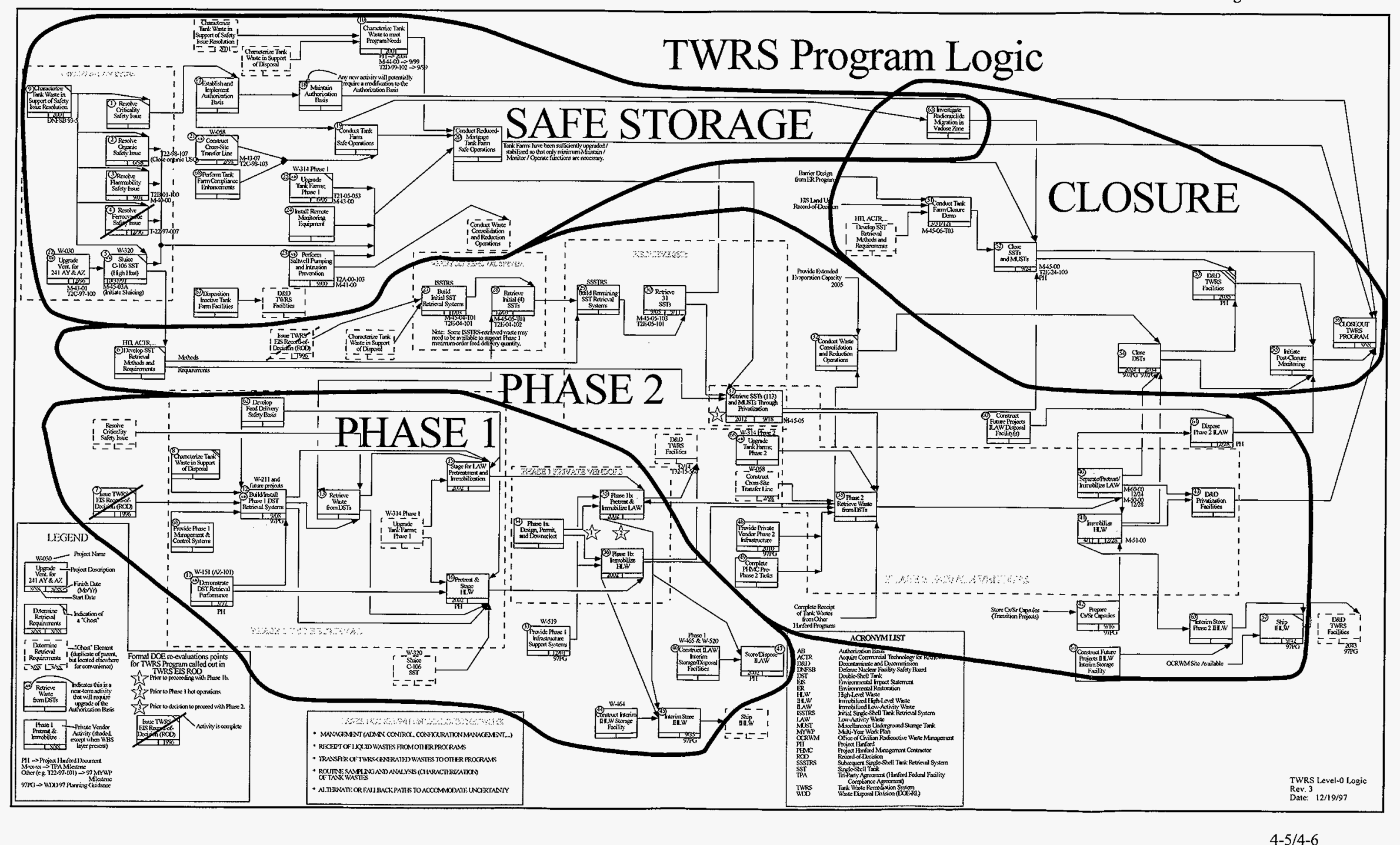


catch tanks, and miscellaneous underground storage tanks (MUST). The work involved is to plan, sample, analyze, and report tank waste contents. Activities include program management, characterization data development, sampling equipment development, sample and measurement acquisition, and sample analyses.

Key elements of this project are to characterize Hanford Site waste tanks to satisfy Tri-Party Agreement Milestone M-44-00 and DNFSB Recommendation 93-5, Hanford Waste Tanks Characterization Studies (DNFSB 1993a).

\subsection{Geographic Requirements/Assumptions.}

\section{Requirements:}

- None.

\section{Planning Assumptions:}

- The 200 Area and Central Plateau will be used for the management of NM, the collection and disposal of waste materials that remain onsite, and for other related and compatible uses. Cleanup levels and disposal standards will be established that are consistent with the long-term uses.

- The Tank Waste Characterization Project will support the prior assumption by providing characterization data and analysis to the Tank Farm Operations, Tank Safety Issue Resolution, and Retrieval Projects, which ensure safe storage of tank waste contents in the 200 Area where the waste is retrieved. This project also provides samples to TWRS Privatization Phase I. The Tank Waste Characterization Project concludes in 2002. After 2002, the Retrieval Project will be responsible for waste characterization.

4.2.1.1.3 Material and Waste Flow Requirements/Assumptions. This project has no responsibility for managing waste inventory but does manage sampling of tank waste.

4.2.1.1.4 Facility Life-Cycle Requirements/Assumptions. The Tank Waste Characterization Project provides support by characterizing the radioactive $\mathrm{HLW}$ for Projects RL-TW03, Tank Farm Operations Project and RL-TW04, Retrieval Project, which have phased responsibility for the operations and maintenance of the tank farm facilities. In addition, this project supports the RL-TW06 TWRS Privatization Phase I facilities. 


\begin{tabular}{|c|c|c|c|c|c|c|c|c|c|}
\hline \multirow{3}{*}{$\begin{array}{l}\text { Major } \\
\text { facility }\end{array}$} & \multicolumn{9}{|c|}{ Life cycle } \\
\hline & \multirow{2}{*}{$\begin{array}{l}\text { Program } \\
\text { planning }\end{array}$} & \multirow{2}{*}{$\begin{array}{c}\text { Pre- } \\
\text { conceptual }\end{array}$} & \multirow{2}{*}{ Conceptual } & \multicolumn{3}{|c|}{ Execute } & \multirow{2}{*}{$\begin{array}{l}\text { Operations } \\
\text { and } \\
\text { maintenance }\end{array}$} & \multicolumn{2}{|c|}{ Close out } \\
\hline & & & & Design & Construction & Turnover & & $\begin{array}{c}\text { Post- } \\
\text { operations }\end{array}$ & $D \& D$ \\
\hline $\begin{array}{l}\text { Single- } \\
\text { Shell } \\
\text { Tanks }\end{array}$ & -- & $\cdots$ & - & $\cdots$ & .. & $\cdots$ & $\begin{array}{l}\text { RL-TW01 } \\
\text { supporting } \\
\text { RL-TW03 } \\
\text { RL-TW04 }\end{array}$ & $=$ & -- \\
\hline $\begin{array}{l}\text { Double- } \\
\text { Shell } \\
\text { Tanks }\end{array}$ & -. & -- & -- & $\cdots$ & -. & - - & $\begin{array}{l}\text { RL-TW01 } \\
\text { supporting } \\
\text { RL-TW03 } \\
\text { RL-TW04 }\end{array}$ & -. & -- \\
\hline
\end{tabular}

$\mathrm{D} \& \mathrm{D}=$ decontamination and decommissioning

This project has no ownership assignments for the waste tank facilities.

4.2.1.1.5 Project Safety Authorization Basis/NEPA and Permits. The Authorization Basis consists of those aspects of the facility design basis and operational requirements relied upon by the DOE to authorize operation. These aspects are considered important to the safety of the facility operations. The complete list of documents that comprise the Authorization Basis for TWRS facilities and activities is provided in Attachment A of HNF-IP-0842, TWRS Administration, Volume IV, Section 5.4, "Unreviewed Safety Questions" (FDH 1998a).

The Tank Waste Characterization Project operates under the requirements of DOE/EA-0915, Environmental Assessment - Waste Tank Safety Program, Hanford Site, Richlond, Washington (RL 1994), which was issued for compliance with NEPA. In addition, DOE/EIS-0212, Safe Interim Storage of Hanford Tank Waste Final Environmental Impact Statement (SIS EIS) (RL and Ecology 1995) was issued in October 1995. Subsequently, the DOE issued the Record of Decision (ROD): Safe Interim Storage of Hanford Tank Wastes, Hanford Site, Richland, WA (DOE 1995a) on November 21, 1995, following concurrence by the State of Washington. Additional environmental permits required for compliance with federal and state air pollution regulations are developed and approved as needed on a project-specific basis. State air pollution permits also activate the State Environmental Policy Act of 1971 requirements and are also addressed on a project-specific basis.

\subsection{Other Requirements and Planning Assumptions, Including DNFSB.}

\section{Requirements:}

- Tri-Party Agreement Milestone M-44-00A, “Complete Delivery of Information Requirements as Identified in Annually Submitted Waste Information Requirements Document (WIRD)"

- DNFSB Recommendation 93-5, documented in DOE/RL-94-1, Recommendation 93-5 Implementation Plan - February 1996 - Draft (Pennington 1996). 


\section{Planning Assumptions:}

- The DOE plans to sample and analyze waste from as many of the 177 Hanford Site waste tanks as necessary to resolve safety issues, manage waste safely, retrieve tank waste, and support the Privatization Phase I Project.

- The strategy for identifying tank sampling priorities is based on various data quality objectives for the Tank Safety Issue Resolution Project, the Tank Farm Operations Project, and the Retrieval Project and is reflected in the current revision of HNF-SD-WM-TA-164, Tank Characterization Technical Sampling Basis (Brown 1998).

- The Tank Waste Characterization Project will complete waste characterization activities required by DNFSB Recommendation $93-5$ by the end of 2001. After 2001, any remaining work will be transferred to the Retrieval Project.

4.2.1.1.7 Interfaces. This project provides, receives, or shares in the following interfaces:

\begin{tabular}{|c|c|c|}
\hline Project title & Project number & Interface \\
\hline Tank Safety Issue Resolution & RL-TWO2 & $\begin{array}{l}\text { Receives data quality objectives } \\
\text { Provides sample analysis and tank characterization reports } \\
\text { Cooperates to resolve safety issues }\end{array}$ \\
\hline Tank Farm Operations & RL-TW03 & $\begin{array}{l}\text { Receives data quality objectives and samples } \\
\text { Provides characterization data and analysis }\end{array}$ \\
\hline Retrieval & RL-TW04 & $\begin{array}{l}\text { Receives data quality objectives } \\
\text { Provides characterization data } \\
\text { Provides/transitions characterization activities to Retrieval }\end{array}$ \\
\hline Privatization Phase I & RL-TW06 & Provides samples \\
\hline Process Waste Support & RL-TWOS & Receives/provides interface input to the Privatization Project \\
\hline $\begin{array}{l}\text { Tank Waste Remediation } \\
\text { System Management Support }\end{array}$ & RL-TW10 & $\begin{array}{l}\text { Receives management, budgeting, and cost reporting support } \\
\text { Cooperates in outyear planning }\end{array}$ \\
\hline Analytical Services & RL-WM06 & Receives sample analysis \\
\hline
\end{tabular}

The Waste Management Program will provide solid waste, liquid waste, and Analytical Laboratory support as defined in the most recent approved revision of the solid waste, liquid waste, and Analytical Laboratory Services forecasts.

4.2.1.1.8 Logic Diagram. Refer to Figure 4-2.

\subsection{Requirements References.}

- 10 CFR 20, "Standards for Protection Against Radiation" 
- 10 CFR 830, "Nuclear Safety Management"

- 10 CFR 830.120, "Quality Assurance Requirements"

- 10 CFR 835, "Occupational Radiation Protection"

- 10 CFR 962, "By-Product Material"

- 29 CFR 1910, "Occupational Safety and Health Standards"

- 40 CFR 50, "National Primary and Secondary Ambient Air Quality Standards"

- 40 CFR 61, "National Emission Standards for Hazardous Air Pollutants"

- 40 CFR 141, "National Primary Drinking Water Regulations"

- 40 CFR 191, "Environmental Radiation Protection Standards for Management and Disposal of Spent Nuclear Fuel, High-Level and Transuranic Radioactive Wastes"

- 40 CFR 264, "Standards for Owners and Operators of Hazardous Waste Treatment, Storage, and Disposal Facilities"

- 40 CFR 265, "Interim Status Standards for Owners and Operators of Hazardous Waste Treatment, Storage, and Disposal Facilities"

- WAC 173-200, "Water Quality Standards for Ground Waters of the State of Washington"

- WAC 173-201A, "Water Quality Standards for Surface Waters of the State of Washington"

- WAC 173-303, "Dangerous Waste Regulations"

- WAC 173-360, "Underground Storage Tank Regulations"

-WAC 173 400, "General Regulations for Air Pollution Sources"

- WAC 173-401, "Operating Permit Regulation"

- WAC 173-460, "Controls for New Sources of Toxic Air Pollutants"

- WAC 173-480, “Ambient Air Quality Standards and Emission Limits for Radionuclides"

- WAC 246-247, "Radiation Protection--Air Emissions" 
DOE/RL-97-55

Revision 0

May 29, 1998

- DOE Order 5400.1, General Environmental Protection Program (DOE 1988a)

- DOE Order 5400.5, Radiation Protection of the Public and the Environment (DOE 1990a)

- DOE Order 451.1A, National Environmental Policy Act Compliance Program (DOE 1997b)

- DOE Order 5480.3, Safety Requirements for the Packaging and Transportation of Hazardous Materials, Hazardous Substances, and Hazardous Wastes (DOE 1985)

- DOE Order 5480.7A, Fire Protection (DOE 1993)

- DOE Order 5480.11, Radiation Protection for Occupational Workers (DOE 1988b)

- DOE Order 5480.19, Conduct of Operations Requirements for DOE Facilities (DOE 1990b)

- DOE Order 5480.21, Unreviewed Safety Questions (DOE 1991a)

- DOE Order 5480.23, Nuclear Safety Analysis Reports (DOE 1992a)

- DOE Order 5483.1A, Occupational Safety and Health Program for DOE Contractors Employees at Government-Owned Contractor-Operated Facilities (DOE 1983)

- DOE Order 5632.1C, Protection and Control of Safeguards and Security Interests. (DOE 1994a)

- DOE Order 5700.6C, Quality Assurance (DOE 1991b)

- DOE Order 5820.2A, Radioactive Waste Management (DOE 1988c)

- DOE Order 4330.4B, Maintenance Management Program (DOE 1994b)

- DOE Order 425.1, Startup and Restart of Nuclear Facilities (DOE 1995b)

- DOE Order 6430.1A, General Design Criteria (DOE 1989).

4.2.1.2 Tank Safety Issue Resolution Project. This section is based on the TWRS baseline as of June 1, 1998. Following selection of the privatization contractor, this information will be updated to reflect the contractor's process and interface with the rest of the TWRS process.

4.2.1.2.1 Project Description Summary. The Tank Safety Issue Resolution Project resolves high-priority tank safety issues to ensure safe storage of waste. This project develops the technical basis for closure of the USQs and removal of all tanks from the Watch List. This project 
also supports upgrades to the safety analysis report, which is the Authorization Basis for monitoring for safe operations of the tank farms and continued safe storage of the tank contents.

The Tank Safety Issue Resolution Project was established to address hazards associated with the storage of radioactive mixed waste in the large, underground storage tanks at the Hanford Site. Safety issues have been raised for SSTs and DSTs with regard to flammable gas, organics, high heat, criticality, and ferrocyanide. The ferrocyanide safety issue was resolved in December 1996. Tanks of the highest concern have been placed on the Watch List in response to Public Law 101-510, National Defense Authorization Act for Fiscal Year 1991, Section 3137 , "Safety Measures for Waste Tanks at Hanford Nuclear Reservation."

\subsection{Geographic Requirements/Assumptions.}

\section{Requirements:}

- None.

\section{Planning Assumptions:}

- The 200 Area and Central Plateau will be used for the management of NM, and the collection and disposal of waste materials that remain onsite, and for other related and compatible uses. Cleanup levels and disposal standards will be established that are consistent with the long-term uses.

- The Tank Safety Issue Resolution Project will support the prior assumption by ensuring safe storage of waste tank contents in the 200 Area until the waste is retrieved for treatment or disposal. The end point target for this project is to mitigate and/or resolve all tank safety issues for high-priority Watch List tanks by September 2001.

4.2.1.2.3 Material and Waste Flow Requirements/Assumptions. This project has no responsibility for managing waste inventory.

4.2.1.2.4 Facility Life-Cycle Requirements/Assumptions. The Tank Safety Issue Resolution Project supports Project RL-TW03, Tank Farm Operations Project, which has responsibility for operations and maintenance of the DSTs and SSTs. This project supports the life cycle of following facilities: 


\begin{tabular}{|c|c|c|c|c|c|c|c|c|c|}
\hline \multirow{3}{*}{$\begin{array}{l}\text { Major } \\
\text { facility }\end{array}$} & \multicolumn{9}{|c|}{ Life cycle } \\
\hline & \multirow{2}{*}{$\begin{array}{l}\text { Program } \\
\text { planning }\end{array}$} & \multirow{2}{*}{$\begin{array}{c}\text { Pre- } \\
\text { conceptual }\end{array}$} & \multirow[b]{2}{*}{ Conceptual } & \multicolumn{3}{|c|}{ Execute } & \multirow{2}{*}{$\begin{array}{l}\text { Operations } \\
\text { and } \\
\text { maintenance }\end{array}$} & \multicolumn{2}{|c|}{ Close out } \\
\hline & & & & Design & Construction & Turnover & & $\begin{array}{c}\text { Post- } \\
\text { operations }\end{array}$ & $D \& D$ \\
\hline $\begin{array}{l}\text { Single- } \\
\text { Shell } \\
\text { Tank } \\
\text { System }\end{array}$ & $\cdots$ & $\cdots$ & $\cdots$ & - & - & - & $\begin{array}{l}\text { RL-TW02 } \\
\text { supporting } \\
\text { RL-TW03 }\end{array}$ & $=$ & $\cdots$ \\
\hline $\begin{array}{l}\text { Double- } \\
\text { Shell } \\
\text { Tank } \\
\text { System }\end{array}$ & $\cdots$ & $\cdots$ & $\cdots$ & -- & $\cdots$ & $\cdots$ & $\begin{array}{l}\text { RL-TW02 } \\
\text { supporting } \\
\text { RL-TW03 }\end{array}$ & - & $\cdots$ \\
\hline
\end{tabular}

$\mathrm{D} \& \mathrm{D}=$ decontamination and decommissioning

This project has no ownership assignments for the waste tank facilities.

4.2.1.2.5 Project Safety Authorization Basis/NEPA and Permits. The Authorization Basis consists of those aspects of the facility design basis and operational requirements relied upon by the DOE to authorize operation. This project exists primarily because conditions may be present which are not adequately covered by an Authorization Basis. The complete list of documents that comprise the Authorization Basis for TWRS facilities and activities is provided in Attachment A of HNF-IP-0842, TWRS Administration, Volume IV, Section 5.4, "Unreviewed Safety Questions" (FDH 1998a).

The Tank Safety Issue Resolution Project operates under the requirements of DOE/EA-0915, Environmental Assessment - Waste Tank Safety Program, Hanford Site, Richland, Washington (RL 1994), which was issued for compliance with NEPA. In addition, DOE/EIS-0212, Safe Interim Storage of Hanford Tank Waste Final Environmental Impact Statement (SIS EIS (RL and Ecology 1995) was issued in October 1995. Subsequently, the DOE issued the Record of Decision (ROD): Safe Interim Storage of Hanford Tank Wastes, Hanford Site, Richland, WA (DOE 1995a) on November 21, 1995, following concurrence by the State of Washington. Additional environmental permits required for compliance with federal and state air pollution regulations are developed and approved as needed on a project-specific basis.

\subsection{Other Requirements and Planning Assumptions, Including DNFSB.}

\section{Requirements:}

- DNFSB Recommendation 93-5, documented in DOE/RL-94-1, Recommendation 93-5 Implementation Plan, February 1996 - Draft (Pennington 1996)

- Tri-Party Agreement Milestone M-40-00, "Mitigate/Resolve Tank Safety Issues for High-Priority Watch List Tanks." 


\section{Planning Assumptions:}

- The SSTs and DSTs requiring characterization to address the flammable gas and organic safety issues will be sampled in a timely manner by Project RL-TW01, Tank Waste Characterization Project.

- The flammable gas USQ on the 176 DSTs and SSTs, but not on the other ancillary tanks (double-contained receiver tanks, catch tanks, etc.) for which the USQ applies, will be closed.

- Two spare mitigation mixer pumps and a pump removal system are available for tank 241-SY-101; however, removal and replacement of the current pump are not planned. Project RL-TW03, Tank Farm Operations Project, is responsible for operation of the mixer pump.

- Mixer pumps will not be required for any other tanks (except tank 241-SY-101) to mitigate the hazard of episodic gas releases.

- Moisture monitoring and control will be the mitigation method used, if necessary, to prevent condensed-phase propagating chemical reactions.

- Safety hazards related to the presence of a separable organic solvent phase in the waste will not require mitigation to ensure continued safe interim storage.

Tank 241-C-103 can be interim stabilized without removing the organic layer.

- The high-heat safety issue will be resolved following removal of sufficient high-heat sludge from tank 241-C-106 to eliminate the need for periodic water additions. Project RL-TW04, Retrieval Project, is responsible for the sluicing of waste.

\subsection{Interfaces.}

This project provides, receives, or shares in the following interfaces:

\begin{tabular}{|l|c|l|}
\hline \multicolumn{1}{|c|}{ Project title } & $\begin{array}{c}\text { Project } \\
\text { number }\end{array}$ & \multicolumn{1}{|c|}{ Interface } \\
\hline $\begin{array}{l}\text { Tank Farm } \\
\text { Operations }\end{array}$ & RL-TW03 & $\begin{array}{l}\text { Provides closure of unreviewed safety questions } \\
\text { Provides removal of tanks from Watch List } \\
\text { Provides removal of operational restrictions } \\
\text { Provides input for operation and maintenance of installed safety systems }\end{array}$ \\
\hline $\begin{array}{l}\text { Tank Waste } \\
\text { Characterization }\end{array}$ & RL-TW01 & $\begin{array}{l}\text { Provides data quality objectives } \\
\text { Receives sampling, analysis, and tank characterization reports } \\
\text { Cooperates in the closure of safety issues }\end{array}$ \\
\hline Retrieval & RL-TW04 & $\begin{array}{l}\text { Provides waste property data } \\
\text { Provides closure of unreviewed safety questions } \\
\text { Provides input to actions necessary for final resolution of safety issues, such as } \\
\text { sluicing of high-heat sludge from tank 24l-C-106 }\end{array}$ \\
\hline
\end{tabular}


DOE/RL-97-55

Revision 0

May 29, 1998

\begin{tabular}{|l|c|l|}
\hline \multicolumn{1}{|c|}{ Project title } & $\begin{array}{c}\text { Project } \\
\text { number }\end{array}$ & \multicolumn{1}{|c|}{ Interface } \\
\hline $\begin{array}{l}\text { TWRS } \\
\text { Management } \\
\text { Support }\end{array}$ & RL-TW10 & $\begin{array}{l}\text { Receives management, budgeting, and cost reporting support } \\
\text { Cooperates in outyear planning }\end{array}$ \\
\hline
\end{tabular}

TWRS $=$ Tank Waste Remediation System

The Waste Management Program will provide solid waste, liquid waste, and Analytical Laboratory support as defined in the most recent approved revision of the solid waste, liquid waste, and Analytical Laboratory Services forecasts.

4.2.1.2.8 Logic Diagram. Refer to Figure 4-2.

\subsection{Requirements References.}

- Public Law 101-510, National Defense Authorization Act for Fiscal Year 1991, Section 3137, "Safety Measures for Waste Tanks at Hanford Nuclear Reservation"

- DOE Order 5480.21, Unreviewed Safety Questions (DOE 1991a)

- DOE Order 5480.22, Technical Safety Requirements (DOE 1992b)

- DOE Order 5480.23, Nuclear Safety Analysis Reports (DOE 1992a).

4.2.1.3 Tank Farm Operations Project. This section is based on the TWRS baseline as of June 1, 1998. Following selection of the privatization contractor, this information will be updated to reflect the contractor's process and interface with the rest of the TWRS process.

4.2.1.3.1 Project Description Summary. The Tank Farm Operations Project operates, maintains, and upgrades the tank farm facilities to ensure the safe storage of the tank wastes until they are retrieved. Ongoing activities include waste surveillance, maintenance of tank farm facilities, and receipt and transfer of radioactive liquid waste from other Hanford Site facilities.

In addition, this project is interim stabilizing the SSTs by pumping interstitial liquid from the SSTs (saltwell pumping), disconnecting piping to prevent further liquid intrusion (isolation), and reducing surface contamination above the tanks. Interim stabilization of SSTs will be completed in accordance with Tri-Party Agreement Milestone M-41-00. Turnover of SSTs to the Retrieval Project will be accomplished in 2002 followed by turnover of DSTs in 2006 .

This project includes major infrastructure capital improvements to the primary tank farm support systems. 
DOE/RL-97-55

Revision 0

May 29, 1998

\subsection{Geographic Requirements/Assumptions.}

\section{Requirements:}

- None.

\section{Planning Assumptions:}

- The 200 Area and Central Plateau will be used for the management of NM, the collection and disposal of waste materials that remain onsite, and for other related and compatible uses. Cleanup levels and disposal standards will be established that are consistent with the long-term uses.

- The Tank Farm Operations Project will support the prior assumption by managing and storing tank waste in the Central Plateau.

4.2.1.3.3 Material and Waste Flow Requirements/Assumptions. The HLW is contained in 149 SSTs, 28 DSTs, and 48 MUSTs assigned to TWRS. The current inventory is approximately $204,000 \mathrm{~m}^{3}$ (Hanlon 1997), as shown in the following table.

\begin{tabular}{|l|c|c|}
\hline & Total $\left(\mathrm{m}^{3}\right)$ & Total $(\mathrm{kgal})$ \\
\hline Single-shell tank waste & 133,747 & 35,336 \\
\hline Double-shell tank waste & 69,466 & 18,353 \\
\hline Subtotal & 203,213 & 53,689 \\
\hline Miscellaneous underground storage tanks & $\sim 624$ & $\sim 165^{*}$ \\
\hline Total & 203,837 & 53,854 \\
\hline
\end{tabular}

*NOTE: Some miscellaneous underground storage tank volumes are to be determined.

\section{Requirements:}

- The Tank Farm Operations Project shall safely store the TWRS wastes, presently stored in 177 underground storage tanks.

- The Tank Farm Operations Project shall use waste minimization and evaporation to manage the waste volume such that the tank capacity of existing DSTs is not exceeded.

\section{Planning Assumptions:}

- None.

4.2.1.3.4 Facility Life-Cycle Requirements/Assumptions. The Tank Farm Operations Project will transfer responsibility for operation and maintenance of the SSTs to the Retrieval 
Project in FY 2002 and the DSTs to the Retrieval Project in FY 2006. The project systems will be managed in accordance with DOE Order 430.1, Life-Cycle Asset Management (DOE 1995c).

\begin{tabular}{|c|c|c|c|c|c|c|c|c|c|}
\hline \multirow{3}{*}{$\begin{array}{l}\text { Major } \\
\text { facility }\end{array}$} & \multicolumn{9}{|c|}{ Life cycle } \\
\hline & \multirow{2}{*}{$\begin{array}{l}\text { Program } \\
\text { planning }\end{array}$} & \multirow{2}{*}{$\begin{array}{c}\text { Pre- } \\
\text { conceptual }\end{array}$} & \multirow[b]{2}{*}{ Conceptual } & \multicolumn{3}{|c|}{ Execute } & \multirow{2}{*}{$\begin{array}{c}\text { Operations } \\
\text { and } \\
\text { maintenance }\end{array}$} & \multicolumn{2}{|c|}{ Close out } \\
\hline & & & & Design & Construction & Turnover & & $\begin{array}{c}\text { Post- } \\
\text { operations }\end{array}$ & D\&D \\
\hline $\begin{array}{l}\text { Single- } \\
\text { Shell Tank } \\
\text { System }\end{array}$ & $\cdots$ & -- & $\cdots$ & -- & $\cdots$ & -- & $\begin{array}{l}\text { RL-TW03 } \\
\text { RL-TW04 }\end{array}$ & -- & $\cdots$ \\
\hline $\begin{array}{l}\text { Double- } \\
\text { Shell Tank } \\
\text { System }\end{array}$ & -- & $\cdots$ & -- & $\cdots$ & -- & - & $\begin{array}{l}\text { RL-TW03 } \\
\text { RL-TW04 }\end{array}$ & -- & $\cdots$ \\
\hline
\end{tabular}

$\mathrm{D} \& \mathrm{D}=$ decontamination and decommissioning

4.2.1.3.5 Project Safety Authorization Basis/NEPA and Permits. The Authorization Basis consists of those aspects of the facility design basis and operational requirements relied upon by the DOE to authorize operation. These aspects are considered important to the safety of the facility operations. The complete list of documents that comprise the Authorization Basis for TWRS facilities and activities is provided in Attachment A of HNF-IP-0842, TWRS Administration, Volume IV, Section 5.4, "Unreviewed Safety Questions" (FDH 1998a).

To comply with NEPA requirements, the DOE and the Washington State Department of Ecology (Ecology) jointly prepared DOE/EIS-0212, Safe Interim Storage of Hanford Tank Waste Final Environmental Impact Statement (SIS EIS) (RL and Ecology 1995). Subsequently, the DOE issued the Record of Decision (ROD): Safe Interim Storage of Hanford Tank Wastes, Hanford Site, Richland, WA (DOE 1995a) on November 21, 1995, following concurrence by the State of Washington.

The SSTs are currently operating in accordance with RCRA interim status requirements and will go directly to closure following retrieval. The DSTs are currently operating under RCRA interim status, and a RCRA final status permit (Part B) application is scheduled for submittal to Ecology in 2000. New project construction must be within the scope of the existing interim status or final status permits or a new or revised permit must be obtained before construction or operation.

\section{2:1.3.6 Other Requirements and Planning Assumptions, Including DNFSB.}

\section{Requirements:}

- Tri-Party Agreement Milestone M-41-00, "Complete Single-Shell Tank Interim Stabilization"

- Tri-Party Agreement Milestone M-43-00, "Complete Tank Farm Upgrades". 
- Tri-Party Agreement Milestone M-46-00, "Double-Shell Tank Space Evaluation"

- DNFSB issue: Recommendation 92-2, Facility Representatives (DNFSB 1992a)

- DNFSB/training issue: Recommendations 90-1, Savannah River Site Operator Training (DNFSB 1990); 92-7, Training and Qualification (DNFSB 1992b); 93-3, Improving DOE Technical Capability in Defense Nuclear Facilities Programs (DNFSB 1993b); etc.

\section{Planning Assumptions:}

- Tank Farm Operations Project facilities and utility and transfer systems shall be upgraded to meet current codes and standards to the extent practicable. Upgrades to selected facilities and systems will be performed to meet mission requirements and achieve a cost-effective, negotiated level of compliance.

- Equipment and facilities will be restored to satisfy interim safe operations requirements.

- Evaporator operations will be used to manage and optimize DST liquid volume. The evaporator is required to achieve the waste volume reduction necessary to avoid the need for additional DSTs at a greatly increased cost, and to provide DST space to support interim stabilization. Waste Management will provide sufficient evaporator capacity to support Operations' waste volume projection requirements.

- Safety issues will be resolved to allow SST pumping in accordance with the Tri-Party Agreement interim milestones. Flammable gas-monitoring equipment will be installed on flammable gas Watch List SSTs before interim stabilization work is scheduled to start on these tanks.

- Project W-058, Cross-Site Transfer System, will be completed in 1998 to provide a RCRA-compliant transfer line. The integrity of the existing two transfer lines can be maintained until Project W-058 is completed.

- Emergency pumping of SSTs will be required until interim stabilization has been completed and all wastes can be co-mingled during pumping.

- Retrieval of SSTs will be initiated by December 2003. Failure to initiate retrieval on schedule will compromise the schedule for $D \& D$ and closure.

- Responsibility for the SST minimum safe operations activity will transfer from the Tank Farm Operations Project to the Retrieval Project in FY 2002.

- The DST Transition Operations activity, infrastructure, and personnel will transfer from the Tank Farm Operations Project to the Retrieval Project in 2006. 


\subsection{Interfaces.}

This project provides, receives, or shares in the following interfaces:

\begin{tabular}{|l|c|l|}
\hline \multicolumn{1}{|c|}{ Project title } & Project number & \multicolumn{1}{c|}{ Interface } \\
\hline Spent Nuclear Fuel & RL-WM01 & Receives sludge from K Basins (September 2000 - August 2001) \\
\hline $\begin{array}{l}\text { Solid Waste Storage \& } \\
\text { Disposal }\end{array}$ & RL-WM03 & Receives solid waste storage and disposal support \\
\hline Liquid Waste Program & RL-WM05 & Receives waste volume reduction (242-A Evaporator) support \\
\hline Tank Waste Characterization & RL-TW01 & $\begin{array}{l}\text { Provides data quality objectives } \\
\text { Receives characterization data }\end{array}$ \\
\hline Tank Safety Issue Resolution & RL-TW02 & $\begin{array}{l}\text { Receives closure of unreviewed safety questions } \\
\text { Receives removal of tanks from Watch List } \\
\text { Receives removal of operational restrictions } \\
\text { Receives input for operations and maintenance of safety systems }\end{array}$ \\
\hline Retrieval & RL-TW04 & $\begin{array}{l}\text { Provides (transitions) tank farms to Retrieval } \\
\text { Receives selection of next generation transfer pump }\end{array}$ \\
\hline $\begin{array}{l}\text { Privatization Infrastructure } \\
\text { Support }\end{array}$ & RL-TW08 & $\begin{array}{l}\text { Provides input to transfer of custody of feed tanks 241-AP-106 } \\
\text { and 241-AP-108 }\end{array}$ \\
\hline TWRS Management Support & RL-TW10 & $\begin{array}{l}\text { Receives management, budgeting, and cost reporting support } \\
\text { Cooperates in outyear planning }\end{array}$ \\
\hline Landlord & RL-TP1 & \begin{tabular}{l} 
Receives utilities from site infrastructure \\
\hline
\end{tabular}
\end{tabular}

TWRS $=$ Tank Waste Remediation Systern

The Waste Management Program will provide solid waste, liquid waste, and Analytical Laboratory support as defined in the most recent approved revision of the solid waste, liquid waste, and Analytical Laboratory Services forecasts.

\subsection{Logic Diagram. Refer to Figure 4-2.}

\subsection{Requirements References.}

- 10 CFR 20, "Standards for Protection Against Radiation"

- 10 CFR 830, "Nuclear Safety Management"

- 10 CFR 830.120, "Quality Assurance Requirements"

- 10 CFR 835, "Occupational Radiation Protection"

- 10 CFR 962, "By-Product Material"

- 29 CFR 1910, "Occupational Safety and Health Standards" 
- 40 CFR 50, "National Primary and Secondary Ambient Air Quality Standards"

- 40 CFR 61, "National Emission Standards for Hazardous Air Pollutants"

- 40 CFR 141, "National Primary Drinking Water Regulations"

- 40 CFR 191, "Environmental Radiation Protection Standards for Management and Disposal of Spent Nuclear Fuel, High-Level and Transuranic Radioactive Wastes"

- 40 CFR 264, "Standards for Owners and Operators of Hazardous Waste Treatment, Storage, and Disposal Facilities"

- 40 CFR 265, "Interim Status Standards for Owners and Operators of Hazardous Waste Treatment, Storage, and Disposal Facilities"

- WAC 173-200, "Water Quality Standards for Ground Waters of the State of Washington"

- WAC 173-201A, "Water Quality Standards for Surface Waters of the State of Washington"

- WAC 173-303, "Dangerous Waste Regulations"

- WAC 173-360, "Underground Storage Tank Regulations"

- WAC 173 400, "General Regulations for Air Pollution Sources"

- WAC 173-401, "Operating Permit Regulation"

- WAC 173-460, "Controls for New Sources of Toxic Air Pollutants"

- WAC 173-480, "Ambient Air Quality Standards and Emission Limits for Radionuclides"

- WAC 246-247, "Radiation Protection--Air Emissions"

- DOE Order 5400.1, General Environmental Protection Program (DOE 1988a)

- DOE Order 5400.5, Radiation Protection of the Public and the Environment (DOE 1990a)

- DOE Order 451.1A, National Environmental Policy Act Compliance Program (DOE 1997b)

- DOE Order 5480.3, Safety Requirements for the Packaging and Transportation of Hazardous Materials, Hazardous Substances, and Hazardous Wastes (DOE 1985) 
DOE/RL-97-55

Revision 0

May 29, 1998

- DOE Order 5480.7A, Fire Protection (DOE 1993)

- DOE Order 5480.11, Radiation Protection for Occupational Workers (DOE 1988b)

- DOE Order 5480.19, Conduct of Operations Requirements for DOE Facilities (DOE 1990b)

- DOE Order 5480.21, Unreviewed Safety Questions (DOE 1991a)

- DOE Order 5480.23, Nuclear Safety Analysis Reports (DOE 1992a)

- DOE Order 5483.1A, Occupational Safety and Health Program for DOE Contractors Employees at Government-Owned Contractor-Operated Facilities (DOE 1983)

- DOE Order 5632.1C, Protection and Control of Safeguards and Security Interests (DOE 1994a)

- DOE Order 5700.6C, Quality Assurance (DOE 1991b)

- DOE Order 5820.2A, Radioactive Waste Management (DOE 1988c)

- DOE Order 4330.4B, Maintenance Management Program (DOE 1994b)

- DOE Order 425.1, Startup and Restart of Nuclear Facilities (DOE 1995b)

- DOE Order 6430.1A, General Design Criteria (DOE 1989).

4.2.1.4 Retrieval Project. This section is based on the TWRS baseline as of June 1, 1998 . Following selection of the privatization contractor, this information will be updated to reflect the contractor's process and interface with the rest of the TWRS process.

4.2.1.4.1 Project Description Summary. The purpose of the Retrieval Project is to retrieve waste from SSTs, DSTs, and designated MUSTs assigned to TWRS; provide waste feed to the privatization contractors; and close tank farms in accordance with regulatory requirements.

The Retrieval Project will assume responsibility for operation and maintenance of the SSTs in FY 2002 and DSTs in FY 2006 from the Tank Farm Operations Project. Beginning in FY 2012, a private contractor will assume responsibility for operation, maintenance, and waste retrieval from SSTs and DSTs except for one tank farm from which waste retrieval operations are complete. This tank farm will be closed. As retrieval operations are completed in other tank farms by the private contractor, they will be transferred back to the PHMC for closure. 


\subsection{Geographic Requirements/Assumptions.}

\section{Requirements:}

- None.

\section{Planning Assumptions:}

- The 200 Area and Central Plateau will be used for the management of NM, the collection and disposal of waste materials that remain onsite, and for other related and compatible uses. Cleanup levels and disposal standards will be established that are consistent with the long-term uses.

- The Retrieval Project will support the prior assumption by retrieving tank waste in the Central Plateau to the extent needed for tank closure. This project will supply the waste as feed to the Privatization Phase I and Phase II Projects for treatment and immobilization. Following retrieval of the tank waste, the SSTs, DSTs, and MUSTs will be closed.

4.2.1.4.3 Material and Waste Flow Requirements/Assumptions. The HLW is contained in 149 SSTs, 28 DSTs, and 48 MUSTs assigned to TWRS. The current inventory is approximately $204,000 \mathrm{~m}^{3}$ (Hanlon 1997).

\section{Requirements:}

- The waste shall be retrieved on a schedule that will support supplying the LAW fraction and HLW fraction to the Privatization Project starting in June 2002. The retrieval of SSTs shall be complete by the end of September 2018 (Tri-Party Agreement Milestone M-45-05). The last feed to the Privatization Phase II Project (completing retrieval of DSTs) shall support completion of $\mathrm{HLW}$ immobilization by the end of December 2028 (Tri-Party Agreement Milestone M-51-00). The feed to the Process Waste Immobilization Phase I Project shall comply with the feed envelopes defined in the privatization contracts.

- The Retrieval Project shall provide the following feed quantities to the Phase I private contractors in accordance with the contract:

\begin{tabular}{|l|l|l|}
\hline \multicolumn{1}{|c|}{ Waste envelope } & \multicolumn{1}{|c|}{ Minimum order quantity per contract } & \multicolumn{1}{c|}{ Maximum order quantity per contract } \\
\hline A & $2,600 \mathrm{MT}$ of sodium & $4,900 \mathrm{MT}$ of sodium* \\
\hline $\mathrm{B}$ & $100 \mathrm{MT}$ of sodium & $1,000 \mathrm{MT}$ of sodium* \\
\hline C & $100 \mathrm{MT}$ of sodium & $2,400 \mathrm{MT}$ of sodium* \\
\hline $\begin{array}{l}\text { D (if high-level waste } \\
\text { included in contract) }\end{array}$ & $\begin{array}{l}245 \mathrm{MT} \text { oxides exclusive of sodium and } \\
\text { silicon }\end{array}$ & $340 \mathrm{MT}$ oxides exclusive of sodium and silicon \\
\hline
\end{tabular}

*The maximum combined quantity of Envelopes A, B, and C shall not exceed 5,100 MT of sodium. 
- Complete closure of all SST farms shall occur by the end of September 2024 (Tri-Party Agreement Milestone M-45-00).

\section{Planning Assumptions:}

- The DOE will award two Phase I privatization contracts. One contract will be for LAW and HLW services and the other contract will be for LAW services only.

- The Retrieval Project will remove at least $99 \%$ of the waste in accordance with TriParty Agreement Milestone M-45-00.

- Phase I will exercise the option to process maximum order quantities.

- Closure of the DST farms will be completed by the end of FY 2034. The Retrieval Project is responsible for closure of SST and DST farms. The Retrieval Project will initiate post-closure monitoring, which will be coordinated with Site post-closure monitoring actions.

\subsection{Facility Life-Cycle Requirements/Assumptions.}

\section{Requirements:}

- The retrieval systems acquired by the PHMC Contractor shall be in accordance with DOE Order 430.1, Life-Cycle Asset Management (DOE 1995c).

\section{Planning Assumptions:}

- The Retrieval Project will assume responsibility for operation and maintenance of the SSTs in FY 2002 and DSTs in FY 2006 from the Tank Farm Operations Project. Beginning in FY 2012, a private contractor will assume responsibility for operation, maintenance, and waste retrieval from SSTs and DSTs. The PHMC contractor will be responsible for closure of the tank farms.

- The Retrieval Project will deactivate the retrieval and operating systems after waste retrieval is completed.

- Responsibility for the tank farms will be returned to the PHMC Contractor following deactivation. The Retrieval Project will close the operable units and DST farms. 
DOE/RL-97-55

Revision 0

May 29, 1998

\begin{tabular}{|c|c|c|c|c|c|c|c|c|c|}
\hline \multirow{3}{*}{$\begin{array}{l}\text { Major } \\
\text { facility }\end{array}$} & \multicolumn{9}{|c|}{ Life cycle } \\
\hline & \multirow{2}{*}{$\begin{array}{l}\text { Program } \\
\text { planning }\end{array}$} & \multirow{2}{*}{$\begin{array}{c}\text { Pre- } \\
\text { conceptual }\end{array}$} & \multirow[b]{2}{*}{ Conceptual } & \multicolumn{3}{|c|}{ Execute } & \multirow{2}{*}{$\begin{array}{l}\text { Operations and } \\
\text { maintenance }\end{array}$} & \multicolumn{2}{|c|}{ Close out } \\
\hline & & & & Design & Construction & Turnover & & $\begin{array}{c}\text { Post- } \\
\text { operations }\end{array}$ & $D \& D$ \\
\hline $\begin{array}{l}\text { SST } \\
\text { System }\end{array}$ & $\cdots$ & -. & -- & -- & -- & -- & $\begin{array}{l}\text { RL-TW03 } \\
\text { RL-TW04 }\end{array}$ & RL-TW04 & RL-TW04 \\
\hline $\begin{array}{l}\text { DST } \\
\text { System }\end{array}$ & - & -- & -- & -- & - & - & $\begin{array}{l}\text { RL-TW03 } \\
\text { RL-TW04 }\end{array}$ & RL-TW04 & RL-TW04 \\
\hline
\end{tabular}

D\&D = decontamination and decommissioning

DST = double-shell tank

SST = single-shell tank

4.2.1.4.5 Project Safety Authorization Basis/NEPA and Permits. The Authorization Basis consists of those aspects of the facility design basis and operational requirements relied upon by the DOE to authorize operation. These aspects are considered important to the safety of the facility operations. The complete list of documents that comprise the Authorization Basis for TWRS facilities and activities is provided in Attachment A of HNF-IP-0842, TWRS Administration, Volume IV, Section 5.4, "Unreviewed Safety Questions" (FDH 1998a). The current Authorization Basis does not include all activities planned by the Retrieval Project; therefore, modifications to the current Authorization Basis will be required.

To comply with NEPA requirements, the DOE and Ecology prepared DOE/EIS-0212, Safe Interim Storage of Hanford Tank Waste Final Environmental Impact Statement (SIS EIS) (RL and Ecology 1995). Subsequently, the DOE issued the Record of Decision (ROD): Safe Interim Storage of Hanford Tank Wastes, Hanford Site, Richland, WA (DOE 1995a) on November 21, 1995, following concurrence by the State of Washington.

The TWRS EIS ROD (DOE 1997a) addresses retrieval of the tank waste. Closure plans will be developed leading to a separate NEPA ROD for closure.

The SSTs are currently operating in accordance with RCRA interim status requirements and will go directly to closure following retrieval. The DSTs are currently operating under RCRA interim status and a RCRA final status permit (Part B) application is scheduled for submittal to Ecology in 2000. New project construction must be within the scope of the existing interim status or final status permits or a new or revised permit must be obtained before construction or operation.

Construction and new (or modified) operations within the tank farms that result in emissions to the air require prior approval from the Washington State Department of Health and the U.S. Environmental Protection Agency (EPA) for radionuclides. Ecology approval is required for toxic air pollutants. A Notice of Construction is prepared for each major project and/or activity and submitted to the respective agency for review and approval. Construction cannot commence until all submitted Notices of Construction are approved. 
DOE/RL-97-55

Revision 0

May 29, 1998

Public and worker health and safety requirements are defined in the TWRS mission analysis, SRIDs, and the Safety Authorization Basis.

\subsection{Other Requirements and Planning Assumptions, Including DNFSB.}

\section{Requirements:}

- Tri-Party Agreement Milestone M-45-00, "Complete Closure of All Single-Shell Tank Farms"

- Tri-Party Agreement Milestone M-50-00, "Complete Pretreatment Processing of Hanford Tank Waste"

- Tri-Party Agreement Milestone M-51-00, "Complete Vitrification of Hanford HighLevel Tank Waste"

- Tri-Party Agreement Milestone M-60-00, "Complete Pretreatment and Immobilization of Hanford Low Activity Tank Waste."

\section{Planning Assumptions:}

- In addition to waste retrieval, the Retrieval Project will continue to receive and store newly generated wastes from other Hanford Site projects through 2018 after it assumes responsibility for operation of the DSTs in 2006. Then, it will cease to receive waste from other projects to facilitate closeout of the DSTs.

- The U.S. Nuclear Regulatory Commission will classify residual tank waste as incidental waste to support development of the tank and operable unit closure plan and performance assessment.

- Landfill closure of the tanks in the 200 Areas will be authorized.

- The SST waste retrieval system will be capable of meeting the Tri-Party Agreement milestone requiring $99 \%$ retrieval. This will be sufficient to close tanks without further retrieval. Closure requirements for DSTs will be similar to those for SSTs. Fortyeight MUSTs are included in the SST operable units as ancillary equipment and will be included in SST closure.

- All residual waste, in-tank equipment, structures, and underlying and adjacent contaminated soils will be disposed in-place after suitable treatment in keeping with performance assessment criteria. 


\subsection{Interfaces.}

This project provides, receives, or shares in the following interfaces:

\begin{tabular}{|c|c|c|}
\hline Project title & Project number & Interface \\
\hline $\begin{array}{l}\text { Tank Waste } \\
\text { Characterization }\end{array}$ & RL-TW01 & $\begin{array}{l}\text { Provides data quality objectives } \\
\text { Receives waste characterization data for design and retrieval } \\
\text { sequencing } \\
\text { Receives/transitions characterization activities from Tank Waste } \\
\text { Characterization }\end{array}$ \\
\hline $\begin{array}{l}\text { Tank Safety Issue } \\
\text { Resolution }\end{array}$ & RL-TW02 & $\begin{array}{l}\text { Receives inputs to actions necessary for safety issue resolution and } \\
\text { cooperates in safety issue resolution } \\
\text { Receives waste property data } \\
\text { Receives closure of unreviewed safety questions }\end{array}$ \\
\hline Tank Farm Operations & RL-TW03 & $\begin{array}{l}\text { Provides input to tank farms operation } \\
\text { Receives/transitions tank farm operations } \\
\text { Provides selection of next generation of transfer pump }\end{array}$ \\
\hline Process Waste Support & RL-TW0S & $\begin{array}{l}\text { Receives/provides interface input to the Privatization Project } \\
\text { Provides requirements definition support }\end{array}$ \\
\hline Privatization Phase I & RL-TW06 & $\begin{array}{l}\text { Provides feed (retrieve tank waste, pretreat high-level waste, stage } \\
\text { low-activity waste, and transfer) } \\
\text { Receives returns }\end{array}$ \\
\hline Privatization Phase II & RL-TW07 & $\begin{array}{l}\text { Provides feed delivery support to Privatization Project requirements } \\
\text { definition and down-select process } \\
\text { Provides feed }\end{array}$ \\
\hline $\begin{array}{l}\text { Privatization } \\
\text { Infrastructure }\end{array}$ & RL-TW08 & $\begin{array}{l}\text { Cooperates in integration of utility/service/waste transfer/waste return } \\
\text { requirements }\end{array}$ \\
\hline $\begin{array}{l}\text { Immobilized Tank Waste } \\
\text { Storage \& Disposal }\end{array}$ & RL-TW09 & $\begin{array}{l}\text { Provides waste characteristics input to design of storage and disposal } \\
\text { facilities }\end{array}$ \\
\hline $\begin{array}{l}\text { TWRS Management } \\
\text { Support }\end{array}$ & RL-TW10 & $\begin{array}{l}\text { Receives management, budgeting, and cost reporting support } \\
\text { Cooperates in outyear planning }\end{array}$ \\
\hline $\begin{array}{l}\text { Solid Waste Storage \& } \\
\text { Disposal }\end{array}$ & RL-WM03 & $\begin{array}{l}\text { Receives solid waste disposal services for retrieval operations } \\
\text { Receives waste for double-shell tanks }\end{array}$ \\
\hline Liquid Waste & RL-WM05 & Receives evaporator and liquid effluent disposal support \\
\hline Analytical Services & RL-WM06 & $\begin{array}{l}\text { Receives analytical support for waste retrieval operations and waste } \\
\text { feed delivery } \\
\text { Receives waste for double-shell tanks }\end{array}$ \\
\hline $\begin{array}{l}\text { Advance Reactors } \\
\text { Transition }\end{array}$ & RL-TP11 & $\begin{array}{l}\text { Cooperates in evaluation of the feasibility of sodium coolant use for } \\
\text { enhanced sludge washing } \\
\text { Receives waste for double-shell tanks }\end{array}$ \\
\hline $\begin{array}{l}200 \text { Area Source } \\
\text { Remedial Action }\end{array}$ & RL-ER02 & $\begin{array}{l}\text { Receives barrier performance specification for use in tank farm } \\
\text { closure }\end{array}$ \\
\hline Science \& Technologies & RL-ST02-09 & $\begin{array}{l}\text { Cooperates in Hanford Tank Initiative Project to demonstrate tank } \\
\text { waste retrieval technology and establish closure criteria }\end{array}$ \\
\hline
\end{tabular}


DOE/RL-97-55

Revision 0

May 29, 1998

\begin{tabular}{|l|c|l|}
\hline \multicolumn{1}{|c|}{ Project title } & Project number & \multicolumn{1}{c|}{ Interface } \\
\hline $\begin{array}{l}\text { Transition Project } \\
\text { Management }\end{array}$ & RL-TP12 & Receives waste for double-shell tanks \\
\hline Landlord & RL-TP1 & Receives utilities from site infrastructure \\
\hline
\end{tabular}

TWRS $=$ Tank Waste Remediation System

The Waste Management Program will provide solid waste, liquid waste, and Analytical Laboratory support as defined in the most recently approved revision of the solid waste, liquid waste, and Analytical Laboratory Services forecasts.

4.2.1.4.8 Logic Diagram. Refer to Figure 4-2.

\subsection{Requirements References.}

- 10 CFR 20, "Standards for Protection Against Radiation"

- 10 CFR 830, "Nuclear Safety Management"

- 10 CFR 830.120, "Quality Assurance Requirements"

- 10 CFR 835, "Occupational Radiation Protection"

- 10 CFR 962, "By-Product Material"

- 29 CFR 1910, “Occupational Safety and Health Standards"

- 40 CFR 50, "National Primary and Secondary Ambient Air Quality Standards"

- 40 CFR 61, "National Emission Standards for Hazardous Air Pollutants"

- 40 CFR 191, "Environmental Radiation Protection Standards for Management and Disposal of Spent Nuclear Fuel, High-Level and Transuranic Radioactive Wastes"

- 40 CFR 264, "Standards for Owners and Operators of Hazardous Waste Treatment, Storage, and Disposal Facilities"

- 40 CFR 268, "Land Disposal Restriction"

- 40 CFR 265, "Interim Status Standards for Owners and Operators of Hazardous Waste Treatment, Storage, and Disposal Facilities"

- WAC 173-200, "Water Quality Standards for Ground Waters of the State of Washington" 
DOE/RL-97-55

Revision 0

May 29, 1998

- WAC 173-201A, "Water Quality Standards for Surface Waters of the State of Washington"

- WAC 173-303, "Dangerous Waste Regulations"

- WAC 173-360, “Underground Storage Tank Regulations"

- WAC 173 400, "General Regulations for Air Pollution Sources"

- WAC 173-401, "Operating Permit Regulation"

- WAC 173-460, "Controls for New Sources of Toxic Air Pollutants"

- WAC 173-480, "Ambient Air Quality Standards and Emission Limits for Radionuclides"

- WAC 246-247, "Radiation Protection--Air Emissions"

- DOE Order 5820.2A, Radioactive Waste Management (DOE 1988c), establishes policies, requirements, and guidelines for the DOE's solid LAW. This Order includes a groundwater performance objective, a definition of point of compliance, a limit on the time for compliance, and a long-term protection requirement expressed as a population collective dose limit.

- DE-AC06-96RL13308, TWRS Privatization Contract (RL 1996a)

- DE-AC06-96RL13309, TWRS Privatization Contract (RL 1996b).

4.2.1.5 Process Waste Support Project. This section is based on the TWRS baseline as of June 1, 1998. Following selection of the privatization contractor, this information will be updated to reflect the contractor's process and interface with the rest of the TWRS process.

4.2.1.5.1 Project Description Summary. The Process Waste Support Project administers and integrates the privatization contracts and the interface between the PHMC Contractor and the private contractors. It provides technical management support to the DOE. It includes Integrated Product/Process Teams.

The PHMC Contractor has the responsibility to support Integrated Product/Process Teams and preparation and review of interface control documents, which define, control, and manage interfaces between contractors and the Hanford Site. The PHMC Contractor will provide input and concurrence in support of Phase IA interface control documents and update them to be consistent with Phase $\mathbb{B}$ authorizations.

During Phase I, the PHMC Contractor will support the Waste Disposal Integration Team and Pacific Northwest by (1) providing analysis in support of negotiating, awarding, and 
administering the contract(s) for the design/operate phase, and (2) integrating the contractors' operations with the rest of the Hanford Site. Interfaces with the contractors will be defined.

During Phase II, the PHMC Contractor will provide the same support to the Waste Disposal Integration Team and Pacific Northwest as during Phase I. In addition, the PHMC Contractor will perform analyses required to define performance, product, and infrastructure requirements for the privatization of retrieval, pretreatment, and immobilization of remaining tank waste.

4.2.1.5.2 Geographic Requirements/Assumptions. The Process Waste Support Project is an administration and integration project that does not have facility or operation responsibilities. It supports the Retrieval Project, the Privatization Phase I and Phase II Projects, the Privatization Infrastructure Project, and the Immobilized Tank Waste Storage and Disposal Project in meeting their geographic requirements/assumptions.

\section{Requirements:}

- None

\section{Planning Assumptions:}

- The 200 Area and Central Plateau will be used for the management of NM, the collection and disposal of waste materials that remain onsite, and for other related and compatible uses. Cleanup levels and disposal standards will be established that are consistent with the long-term uses.

- The Process Waste Support Project will support the prior assumption by providing administration and integration of the privatization contracts and the interface between the PHMC Contractor and the private contractors.

4.2.1.5.3 Material and Waste Flow Requirements/Assumptions. The Process Waste Support Project is an administration and integration project that does not have material and waste flow responsibilities.

4.2.1.5.4 Facility Life-Cycle Requirements/Assumptions. No facilities apply to this project.

4.2.1.5.5 Project Safety Authorization Basis/NEPA and Permits. The Process Waste Support Project is an administration and integration project that does not have facility or operation responsibilities. The Process Waste Support Project does not require a safety Authorization Basis.

This project shall support implementation of the TWRS EIS ROD (DOE 1997a).

It is assumed the DOE will retain overall responsibility for ensuring protection of the public and the environment for privatized and non-privatized activities. A special Regulatory Unit 
reporting directly to the RL Operations manager has been established to provide independent radiological and nuclear safety oversight of the private contractors. The Regulatory Unit will function through Phase I of Privatization, after which the U.S. Nuclear Regulatory Commission will assume responsibility for nuclear and process safety.

\subsection{Other Requirements and Planning Assumptions, Including DNFSB.}

\section{Requirements:}

The Process Waste Support Project supports the following requirement:

- Tri-Party Agreement Milestone M-60-10, "Select Two (2) COCO Contractors and Issue DOE Signed Authorizations to Proceed with Part B (as defined in request for proposal [RFP] or subsequently negotiated contracts) Works for LAW Pretreatment and Immobilization."

\section{Planning Assumptions:}

- The DOE will award two Phase I privatization contracts. One contract will be for LAW and HLW services and the other contract will be for LAW services only.

- The strategy for tank waste immobilization will be implemented essentially as described in the privatization contracts, with a LAW plant and a combined LAW/HLW plant.

- Vitrification will be the immobilization technology.

- Private contractors will start to construct Phase I plants by the end of 1999.

- During Phase I, the M\&I Contractor will be responsible for retrieval, preparation, and delivery of waste feed, infrastructure, storage, and disposal of waste products and facility D\&D.

- During Phase I, the private contractors will be responsible for LAW and HLW treatment and immobilization and facility deactivation.

- The option to extend Phase I will be executed through 2011.

- The Phase II private contractors will be responsible for waste retrieval, waste feed delivery, and pretreatment; LAW and HLW immobilization; and facility D\&D.

- Volumes of ILAW and IFLW will be as stated in HNF-SD-WM-SP-012, Tank Waste Remediation System Operation and Utilization Plan (Kirkbride et al. 1997). 


\subsection{Interfaces.}

This project provides, receives, or shares in the following interfaces:

\begin{tabular}{|l|c|l|}
\hline \multicolumn{1}{|c|}{ Project title } & Project number & \multicolumn{1}{c|}{ Interface } \\
\hline Tank Waste Characterization & RL-TW01 & Coordinates input to Tank Waste Characterization Project \\
\hline Retrieval & RL-TW04 & Coordinates input for retrieval and pretreatment of tank waste \\
\hline Privatization Phase I & RL-TW06 & $\begin{array}{l}\text { Provides technical management support } \\
\text { Participates in Integrated Products/Process Teams }\end{array}$ \\
\hline Privatization Phase II & RL-TW07 & Participates in Integrated Products/Process Teams \\
\hline Privatization Infrastructure & RL-TW08 & Coordinates input for infrastructure to support privatization \\
\hline $\begin{array}{l}\text { Immobilized Tank Waste Storage } \\
\text { \& Disposal }\end{array}$ & RL-TW09 & $\begin{array}{l}\text { Coordinates input regarding receipt, storage, and disposal of } \\
\text { immobilized tank waste }\end{array}$ \\
\hline $\begin{array}{l}\text { Tank Waste Remediation System } \\
\text { Management Support }\end{array}$ & RL-TW10 & $\begin{array}{l}\text { Receives management, budgeting, and cost reporting support } \\
\text { Cooperates in outyear planning }\end{array}$ \\
\hline
\end{tabular}

The Waste Management Program will provide solid waste, liquid waste, and Analytical Laboratory support as defined in the most recent approved revision of the solid waste, liquid waste, and Analytical Laboratory Services forecasts.

4.2.1.5.8 Logic Diagram. Refer to Figure 4-2.

\subsection{Requirements References.}

- DE-AC06-96RL13308, TWRS Privatization Contract (RL 1996a)

- DE-AC06-96RL13309, TWRS Privatization Contract (RL 1996b).

\subsubsection{Privatization Phase I Project. See Section 4.5.}

\subsubsection{Privatization Phase II Project. See Section 4.6.}

4.2.1.8 Privatization Infrastructure Project. This section is based on the TWRS baseline as of June 1, 1998. Following selection of the privatization contractor, this information will be updated to reflect the contractor's process and interface with the rest of the TWRS process.

4.2.1.8.1 Project Description Summary. The Privatization Infrastructure Project provides the land, services, utilities, feed tank turnover and roads that will ensure the privatization contractors are integrated into the Hanford Site infrastructure for Phase I and Phase II.

This project also provides funding that covers the cost for electricity and water used by the privatization contractors. The project receives, treats, and disposes of liquid effluents and radioactive solid waste from the privatization contractors. Telecommunications and sanitary 
waste systems will also be provided to the Phase II contractors' sites. Upon completion of the respective phases, the added infrastructure system will be removed and the sites readied for closure.

\subsection{Geographic Requirements/Assumptions.}

\section{Requirements:}

- None

\section{Planning Assumptions:}

- The 200 Area and Central Plateau will be used for the management of NM, the processing and immobilization of LAW and HLW by the private contractors, the collection and disposal of waste materials that remain onsite, and for other related and compatible uses. Cleanup levels and disposal standards will be established that are consistent with the long-term uses.

- The private contractors' Phase I and Phase II plants will be located on the Central Plateau to process the tank waste. Infrastructure systems and facilities will be colocated with these plants. The Privatization Infrastructure Project will support the prior assumption by providing the services, facilities and roads needed to support the private plants.

4.2.1.8.3 Material and Waste Flow Requirements/Assumptions. The project will provide the following services and utilities in support of the Privatization Phase I Project.

\section{Requirements:}

- Provide up to $760 \mathrm{~L} / \mathrm{min}$ (24-hour average) of raw water/process water to each Phase I contractor.

- Provide up to $95 \mathrm{~L} / \mathrm{min}$ (24-hour average) of potable water to each Phase I contractor.

- Provide transportation and disposal services for Phase I contractor-generated radioactive solid wastes.

- Accept up to $300,000 \mathrm{~m}^{3} / \mathrm{yr}$ of nonradioactive, non-dangerous liquid effluents from each Phase I contractor at an average flow rate of $570 \mathrm{~L} / \mathrm{min}$. Accept up to . $100,000 \mathrm{~m}^{3} / \mathrm{yr}$ of radioactive, dangerous liquid effluents from each contractor corresponding to an average flow rate of $190 \mathrm{~L} / \mathrm{min}$.

- Deliver up to $20 \mathrm{MW}$ of power at $13.8 \mathrm{~V}$ to each Phase I contractor. 
- Provide road access between the Phase I contractors' site boundary and existing Hanford Site roads, clear and grub each contractor's site, and perform habitat mitigation.

- Phase II requirements are to be determined.

\section{Planning Assumptions:}

- The DOE will award two Phase I privatization contracts. One contract will be for LAW and HLW services and the other contract will be for LAW services only.

4.2.1.8.4 Facility Life-Cycle Requirements/Assumptions. The following table identifies life-cycle responsibility for major Privatization Infrastructure Project systems.

\section{Requirements:}

\begin{tabular}{|c|c|c|c|c|c|c|c|c|c|}
\hline \multicolumn{1}{|c|}{ Asset } & $\begin{array}{c}\text { Program } \\
\text { planning }\end{array}$ & $\begin{array}{c}\text { Pre- } \\
\text { conceptual }\end{array}$ & Conceptual & Design & Construction & Turnover & O\&M & $\begin{array}{c}\text { Post- } \\
\text { operations }\end{array}$ & D\&D \\
\hline $\begin{array}{l}\text { Privatization } \\
\text { Infrastructure } \\
\text { Systems }\end{array}$ & -- & -- & RL-TW08 & RL-TW08 & RL-TW08 & RL-TW08 & RL-TW08 & RL-TW08 & RL-TW08 \\
\hline
\end{tabular}

$D \& D=$ decontamination and decommissioning

$O \& M=$ operations and maintenance

\section{Planning Assumptions:}

- None at this level of analysis.

4.2.1.8.5 Project Safety Authorization Basis/NEPA and Permits. The Authorization Basis consists of those aspects of the facility design basis and operational requirements relied upon by the DOE to authorize operation. These aspects are considered important to the safety of the facility operations. The complete list of documents that comprise the Authorization Basis for TWRS facilities and activities is provided in Attachment A of HNF-IP-0842, TWRS Administration, Volume IV, Section 5.4, "Unreviewed Safety Questions" (FDH 1998a). In addition, the Waste Management Authorization Basis applies to some elements of this project. The Privatization Infrastructure Project facilities and activities will be evaluated to verify that they are within the current Authorization Basis. If any facilities or activities are determined to be outside the current Authorization Basis, modifications to the Authorization Basis will be required.

\subsection{Other Requirements and Planning Assumptions, Including DNFSB.}

\section{Requirements:}

- Tri-Party Agreement Milestone M-50-00, "Complete Pretreatment Processing of Hanford Tank Waste" 
- Tri-Party Agreement Milestone M-51-00, "Complete Vitrification of Hanford HighLevel Tank Waste"

- Tri-Party Agreement Milestone M-60-00, "Complete Pretreatment and Immobilization of Hanford Low Activity Tank Waste"

- TWRS Privatization Phase IA contracts with BNFL, Inc. (DE-AC06-96RL13308) (RL 1996a) and with Lockheed Martin Advanced Environmental Systems (DE-AC06-96RL13309) (RL 1996b).

\section{Planning Assumptions:}

- Project deliverables related to Phase I are based on the schedule established in the Phase IA contracts.

- Interface control documents, which define DOE and contractor responsibilities and obligations as they apply to project interfaces, will be finalized before the Phase IB contract award.

\subsection{Interfaces.}

This project provides, receives, or shares in the following interfaces:

\begin{tabular}{|l|c|l|}
\hline \multicolumn{1}{|c|}{ Project title } & Project number & \multicolumn{1}{|c|}{ Interface } \\
\hline $\begin{array}{l}\text { Solid Waste Storage \& } \\
\text { Disposal }\end{array}$ & RL-WM03 & Coordinates solid waste treatment and disposal \\
\hline Liquid Waste Program & RL-WM05 & Coordinates treatment and disposal of liquid effluents \\
\hline Tank Farm Operations & RL-TW03 & $\begin{array}{l}\text { Coordinates custody transfer of feed tanks 241-AP-106 and } \\
\text { 24l-AP-108 to the privatization contractors }\end{array}$ \\
\hline Retrieval & RL-TW04 & $\begin{array}{l}\text { Provides integration of waste utility/service/transfer/return } \\
\text { systems }\end{array}$ \\
\hline Process Waste Support & RL-TW05 & $\begin{array}{l}\text { Receives/provides input to integration with private contractors } \\
\text { Provides input to requirements definition }\end{array}$ \\
\hline Privatization Phase I & RL-TW06 & Provides utilities, selected services, and land \\
\hline Privatization Phase II & RL-TW07 & Provides utilities, selected services, and land \\
\hline $\begin{array}{l}\text { Immobilized Tank Waste } \\
\text { Storage \& Disposal }\end{array}$ & RL-TW09 & Provides potable water system access for ILAW Storage Facility. \\
\hline $\begin{array}{l}\text { Tank Waste Remediation } \\
\text { System Management Support }\end{array}$ & RL-TW10 & $\begin{array}{l}\text { Receives management, budgeting, and cost reporting support } \\
\text { Cooperates in outyear planning }\end{array}$ \\
\hline Landlord & RL-TP1 & Receives utilities from site infrastructure \\
\hline
\end{tabular}


The Waste Management Program will provide solid waste, liquid waste, and Analytical Laboratory support as defined in the most recent approved revision of the solid waste, liquid waste, and Analytical Laboratory Services forecasts.

4.2.1.8.8 Logic Diagram. Refer to Figure 4-2.

\subsection{Requirements References.}

- 10 CFR 20, "Standards for Protection Against Radiation"

- 10 CFR 830, "Nuclear Safety Management"

- 10 CFR 830.120, "Quality Assurance Requirements"

- 10 CFR 835, "Occupational Radiation Protection"

- 10 CFR 962, "By-Product Material"

- 29 CFR 1910, "Occupational Safety and Health Standards"

- 40 CFR 50, "National Primary and Secondary Ambient Air Quality Standards"

- 40 CFR 61, "National Emission Standards for Hazardous Air Pollutants"

- 40 CFR 141, "National Primary Drinking Water Regulations"

- 40 CFR 191, "Environmental Radiation Protection Standards for Management and Disposal of Spent Nuclear Fuel, High-Level and Transuranic Radioactive Wastes"

- 40 CFR 264, "Standards for Owners and Operators of Hazardous Waste Treatment, Storage, and Disposal Facilities"

- 40 CFR 265, "Interim Status Standards for Owners and Operators of Hazardous Waste Treatment, Storage, and Disposal Facilities"

- 40 CFR 268, "Land Disposal Restrictions"

- WAC 173-200, "Water Quality Standards for Ground Waters of the State of Washington"

- WAC 173-201A, "Water Quality Standards for Surface Waters of the State of Washington"

- WAC 173-303, "Dangerous Waste Regulations"

- WAC 173-360, "Underground Storage Tank Regulations" 
- WAC 173 400, “General Regulations for Air Pollution Sources"

- WAC 173-401, "Operating Permit Regulation"

- WAC 173-460, "Controls for New Sources of Toxic Air Pollutants"

- WAC 173-480, "Ambient Air Quality Standards and Emission Limits for Radionuclides"

- WAC 246-247, "Radiation Protection--Air Emissions"

- DOE Order 5400.1, General Environmental Protection Program (DOE 1988a)

- DOE Order 5400.5, Radiation Protection of the Public and the Environment (DOE 1990a)

- DOE Order 5440.1E, National Environmental Policy Act Compliance Program (DOE 1992c)

- DOE Order 5480.4, Environmental Protection, Safety and Health Protection (DOE 1984)

- DOE Order 5480.7, Fire Protection (DOE 1993)

- DOE Order 5480.19, Conduct of Operations Requirements for DOE Facilities (DOE 1990b)

- DOE Order 5480.20A, Personnel Selection, Training, and Staffing Requirements at DOE Reactor and Non-Reactor Facilities (DOE 1994c)

- DOE Order 5480.23, Nuclear Safety Analysis Reports (DOE 1992a)

- DOE Order 5481.1B, Safety Analysis and Review System (DOE 1986)

- DOE Order 5484.1, Environmental Protection, Safety, and Health Protection Information Reporting Requirements (DOE 1981)

- DOE Order 5700.6C, Quality Assurance (DOE 1991b)

- DOE Order 5820.2A, Radioactive Waste Management (DOE 1988c)

- DOE Order 6430.1, General Design Criteria, (DOE 1989)

4.2.1.9 Immobilized Tank Waste Storage \& Disposal Project. This section is based on the TWRS baseline as of June 1, 1998. Following selection of the privatization contractor, this 
information will be updated to reflect the contractor's process and interface with the rest of the TWRS process.

4.2.1.9.1 Project Description Summary. The purpose of the Immobilized Tank Waste Storage and Disposal Project is to store immobilized high-level tank waste (and non-routine HLW products, as required) and to dispose of immobilized low activity tank waste in an environmentally sound, safe, secure, and cost effective manner. Storage and Disposal will also define an approach for disposition of $\mathrm{Cs} / \mathrm{Sr}$ capsules in conjunction with TWRS.

The ILAW activity will be complete when the ILAW is disposed of on the Hanford Site, long-term surveillance and monitoring of the ILAW disposal site are ongoing, and D\&D of interim facilities is completed. The ILAW storage and disposal facilities will accept the ILAW from the TWRS privatization vendors. The $I L A W$ packages will be placed in near-surface disposal facilities. The near-surface disposal systems and the waste packages will meet DOE regulatory requirements for near-surface disposal of $L L W$. Waste receipts are planned to commence in 2002 and continue through 2024, consistent with Tri-Party Agreement Milestone M-60-00.

The HLW interim storage activity will receive IHLW, non-routine waste from the HLW contractor, and immobilized Cs product from the low-level plant, and transport these products to the Canister Storage Building (CSB) or other additional storage facilities where the product will be stored until shipped to the geologic repository (IHIW) or returned to the Phase II vendor (Cs).

The $\mathrm{Cs} / \mathrm{Sr}$ capsule disposition activity will address the disposition of the highly radioactive $\mathrm{Cs} / \mathrm{Sr}$ capsules, currently stored in the Waste Encapsulation and Storage Facility (WESF) at the Hanford Site's 200 East Area, so they are acceptable for final disposal in the geologic repository. The scope of this activity is to provide sufficient technical definition such that the disposition scope can be incorporated into the Request for Proposal (RFP) for the Phase II Privatization Project.

\subsection{Geographic Requirements/Assumptions.}

\section{Requirements:}

- None.

\section{Planning Assumptions:}

- The 200 Area and Central Plateau will be used for the management of NM, the collection and disposal of waste materials that remain onsite, and for other related and compatible uses. Cleanup levels and disposal standards will be established that are consistent with the long-term uses. 
- The contractor will use the Central Plateau to dispose of ILAW and store IHLW until they are shipped to the offsite repository. Canister Storage Building Vaults 2 and 3 will be used to store Phase I IHLW and the four former grout disposal vaults will be used to store/dispose ILAW. Additional storage and disposal facilities will be built as needed to support Phase I and Phase II of waste processing.

\subsection{Material and Waste Flow Requirements/Assumptions.}

\section{Requirements:}

- The contractor is required to transport, store, and dispose of the ILAW.

- The contractor is required to provide transport and storage of IHLW, non-routine $\mathrm{HLW}$, and the separated Cs product.

- The IHLW produced during Phase I shall be stored in Vaults 2 and 3 of the CSB.

\section{Planning Assumptions:}

- The DOE will award two Phase I privatization contracts. One contract will be for LAW and HLW services and the other contract will be for LAW services only.

- The ILAW will be produced in two phases. A total of 12,520 packages (nominally 1.2 by 1.2 by $1.8 \mathrm{~m}$ ) will be produced in Phase I of the privatization contracts beginning in June 2002. A total of 83,200 packages will be produced in Phase II of the privatization contracts. The Phase II privatization contract LAW operations will begin in 2012 .

- The IHLW will be produced in two phases. Approximately 600 canisters $(4.5 \mathrm{~m})$ will be produced in Phase I and 10,935 canisters ( $4.5 \mathrm{~m}$ ) will be produced in Phase II. Phase I production will start in 2002 and Phase II production will start in 2012.

- The $\mathrm{Cs} / \mathrm{Sr}$ capsules will be vitrified as $\mathrm{HLW}$ in Privatization Phase II.

- The ILAW will be disposed of in the four existing grout vaults and additional vaults will be constructed when the four are full.

- Additional storage facilities will be required to support Phase II production of IHLW.

4.2.1.9.4 Facility Life-Cycle Requirements/Assumptions. The Immobilized Tank Waste Storage \& Disposal Project is responsible for the life-cycle asset management phases shown in the following table. 
DOE/RL-97-55

Revision 0

May 29, 1998

\begin{tabular}{|c|c|c|c|c|c|c|c|c|c|}
\hline \multirow{3}{*}{$\begin{array}{l}\text { Major } \\
\text { facility }\end{array}$} & \multicolumn{9}{|c|}{ Life cycle } \\
\hline & \multirow{2}{*}{$\begin{array}{l}\text { Program } \\
\text { planning }\end{array}$} & \multirow{2}{*}{$\begin{array}{c}\text { Pre- } \\
\text { conceptual }\end{array}$} & \multirow[b]{2}{*}{ Conceptual } & \multicolumn{3}{|c|}{ Execute } & \multirow{2}{*}{ O\&M } & \multicolumn{2}{|c|}{ Close out } \\
\hline & & & & Design & Construction & Turnover & & $\begin{array}{c}\text { Post- } \\
\text { operations }\end{array}$ & D\&D \\
\hline $\begin{array}{l}\text { TWRS } \\
\text { CSB } \\
\text { Modules } \\
\text { Phase I }\end{array}$ & -. & $-\cdot$ & RL-TW09 & RL-TW09 & RL-TW09 & RL-TW09* & RL-TW09* & RL-TW09* & RL-TW09* \\
\hline $\begin{array}{l}\text { IHLW } \\
\text { Storage } \\
\text { Modules } \\
\text { Phase II }\end{array}$ & RL-TW09 & RL-TW09 & RL-TW09 & RL-TW09 & RL-TW09 & RL-TW09 & RL-TW09 & RL-TW09 & RL-TW09 \\
\hline $\begin{array}{l}\text { LAW } \\
\text { Disposal } \\
\text { Facility }\end{array}$ &.- & .. & RL-TW09 & RL-TW09 & RL-TW09 & RL-TW09 & RL-TW09 & RL-TW09 & RL-TW09 \\
\hline $\begin{array}{l}\text { Addnl. } \\
\text { M_AW } \\
\text { Disposal } \\
\text { Facility }\end{array}$ & RL-TW09 & RL-TW09 & RL-TW09 & RL-TW09 & RL-TW09 & RL-TW09 & RL-TW09 & RL-TW09 & RL-TW09 \\
\hline
\end{tabular}

* CSB constructed and operated by the Spent Nuclear Fuel Project. Tumover, O\&M, post-operations, and D\&D responsibilities are to be resolved.

CSB = Canister Storage Building

$\mathrm{D} \& \mathrm{D}=$ decontamination and decommissioning

IHLW = immobilized high-level waste

ILW = immobilized low-retivity waste

O\&M = operations and maintenance

TWRS $=$ Tank Waste Remediation System

4.2.1.9.5 Project Safety Authorization Basis/NEPA and Permits. The Authorization Basis consists of those aspects of the facility design basis and operational requirements relied upon by the DOE to authorize operation. These aspects are considered important to the safety of the facility operations. The complete list of documents that comprise the Authorization Basis for TWRS facilities and activities is provided in Attachment A of HNF-IP-0842, TWRS

Administration, Volume IV, Section 5.4, "Unreviewed Safety Questions" (FDH 1998a). The current Authorization Basis does not include all activities of the Immobilized Tank Waste Storage \& Disposal Project. Therefore, modifications to the current Authorization Basis will be required.

The project has defined and planned the necessary permits that need to be prepared, reviewed, and issued before startup of the facilities. The recently issued TWRS EIS (DOE 1996a) and ROD (DOE 1997a) provide NEPA coverage for ILAW and IHLW storage and disposal.

A performance assessment is being prepared to examine the long-term environmental and human health effects associated with the planned disposal of the $\mathrm{LAW}$. The assessment is required by Tri-Party Agreement Milestone M-90-05-T01, "Submit Final ILAW Disposal Facility Performance Agreement to Ecology for Review." The U.S. Nuclear Regulatory Commission has indicated that the ILAW would be considered "incidental waste" if the DOE follows its program plan for separating and immobilizing the waste to the maximum extent possible (and technically 
and economically practical). In addition, the LAW must meet Class C standards of 10 CFR 61 . If the performance assessments continue to show that public health and safety would be protected to standards comparable to those established by the U.S. Nuclear Regulatory Commission for the disposal of LLW, the U.S. Nuclear Regulatory Commission will consider it incidental waste. Currently, the DOE and its contractors are obligated to meet the requirements of DOE Order 5820.2A. It is anticipated that DOE Order 435.1 will become the primary regulation governing management and disposal of radioactive wastes at $\mathrm{DOE}$ facilities. operation.

The contractor is responsible for obtaining the required permits to support facility

\subsection{Other Requirements and Planning Assumptions, Including DNFSB.}

\section{Requirements:}

- The requirements for the Immobilized Tank Waste Storage \& Disposal Project contractor are defined in the privatization contract. These requirements may be modified when authorization to proceed is issued for the immobilization facilities in May 1998.

- Tri-Party Agreement Milestone M-20-56, "Submit Canister Storage Facility Part B Dangerous Waste Permit Application to Ecology"

- Tri-Party Agreement Milestone M-20-57, "Submit Interim ILAW Facility Part B Dangerous Waste Permit Application to Ecology"

- Tri-Party Agreement Milestone M-20-58, "Submit LAW Disposal Facility part B Dangerous Waste Permit Application to Ecology"

- Tri-Party Agreement Milestone M-90-00, "Complete Acquisition of New Facilities, Modification of Existing Facilities, and/or Modification of Planned Facilities as Necessary for Storage of Hanford Site IHLW and ILAW, and Disposal of ILAW"

- ILAW disposal depends on site composite analysis response to DNFSB Recommendation 94-2, Conformance with Safety Standards at DOE Low-Level Nuclear Waste and Disposal Sites (DNFSB 1994a).

\section{Planning Assumptions:}

- The ILAW will be produced in accordance with product specifications in the privatization contracts. Waste will be disposed in accordance with the LAW disposal criteria.

- The XAW will meet U.S. Nuclear Regulatory Commission criteria for incidental waste. 
4.2.1.9.7 Interfaces. The contractor shall interface with the privatization contractors to ensure integration between the storage and disposal systems and the treatment and immobilization system. An interface with the offsite repository shall be maintained to ensure that the production and storage of IHLW do not preclude its eventual disposal at the repository.

An interface with the Facility Stabilization Project operating WESF where the $\mathrm{Cs} / \mathrm{Sr}$ capsules are stored and the Phase II Privatization Project is required to ensure the capsules are vitrified as part of Phase II.

This project provides, receives, or shares in the following interfaces:

\begin{tabular}{|c|c|c|}
\hline Project title & Project number & Interface \\
\hline Retrieval & RL-TW04 & $\begin{array}{l}\text { Receives waste characteristic input for storage and disposal } \\
\text { facilities design }\end{array}$ \\
\hline Process Waste Support & RL-TW05 & $\begin{array}{l}\text { Provides/receives input to integration with private contractors } \\
\text { (includes specifications, testing, etc.) } \\
\text { Provides input to requirements definition }\end{array}$ \\
\hline Privatization Phase I & RL-TW06 & Receives immobilized waste \\
\hline Privatization Phase II & RL-TW07 & Receives immobilized waste \\
\hline Privatization Infrastructure & RL-TW08 & $\begin{array}{l}\text { Receives potable water access for Immobilized Low-Activity } \\
\text { Waste Storage Facility }\end{array}$ \\
\hline $\begin{array}{l}\text { Tank Waste Remediation System } \\
\text { Management Support }\end{array}$ & RL-TW10 & $\begin{array}{l}\text { Receives management, budgeting, and cost reporting support } \\
\text { Cooperates in outyear planning }\end{array}$ \\
\hline $\begin{array}{l}\text { Waste Encapsulation and Storage } \\
\text { Facility }\end{array}$ & RL-TP02 & Receives $\mathrm{Cs} / \mathrm{Sr}$ capsules for transfer to Phase II Privatization \\
\hline Spent Nuclear Fuel & RL-WMO1 & $\begin{array}{l}\text { Receives two Canister Storage Building modules for } \\
\text { Project W.464 }\end{array}$ \\
\hline $\begin{array}{l}\text { Canister Storage Building } \\
\text { Operations }\end{array}$ & RL-WMO2 & Receives two Canister Storage Building modules for storage \\
\hline Solid Waste Storage \& Disposal & RL-WM03 & Provides solid waste for storage and disposal \\
\hline Liquid Waste Program & RL-WMOS & $\begin{array}{l}\text { Provides liquid waste for treatment and disposal (leachate } \\
\text { collection) }\end{array}$ \\
\hline Landlord & RL-TP1. & Receives utilities from site infrastructure \\
\hline
\end{tabular}

The Waste Management Program will provide solid waste, liquid waste, and Analytical Laboratory support as defined in the most recent approved revision of the solid waste, liquid waste, and Analytical Laboratory Services forecasts.

\subsection{Logic Diagram. Refer to Figure 4-2.}




\subsection{Requirements References.}

- 10 CFR 20, "Standards for Protection Against Radiation"

- 10 CFR 830, "Nuclear Safety Management"

- 10 CFR 830.120, "Quality Assurance Requirements"

- 10 CFR 835, "Occupational Radiation Protection"

- 10 CFR 962, "By-Product Material"

- 29 CFR 1910, "Occupational Safety and Health Standards"

- 40 CFR 50, "National Primary and Secondary Ambient Air Quality Standards"

- 40 CFR 61, "National Emission Standards for Hazardous Air Pollutants"

- 40 CFR 141, "National Primary Drinking Water Regulations"

- 40 CFR 191, "Environmental Radiation Protection Standards for Management and Disposal of Spent Nuclear Fuel, High-Level and Transuranic Radioactive Wastes"

- 40 CFR 264, "Standards for Owners and Operators of Hazardous Waste Treatment, Storage, and Disposal Facilities"

- 40 CFR 265, "Interim Status Standards for Owners and Operators of Hazardous Waste Treatment, Storage, and Disposal Facilities"

- 40 CFR 268, "Land Disposal Restrictions"

- WAC 173-200, "Water Quality Standards for Ground Waters of the State of Washington"

- WAC 173-201A, "Water Quality Standards for Surface Waters of the State of Washington"

- WAC 173-303, "Dangerous Waste Regulations"

- WAC 173-360, "Underground Storage Tank Regulations"

- WAC 173 400, "General Regulations for Air Pollution Sources"

- WAC 173-401, "Operating Permit Regulation"

- WAC 173-460, "Controls for New Sources of Toxic Air Pollutants" 
DOE/RL-97-55

Revision 0

May 29, 1998

- WAC 173-480, “Ambient Air Quality Standards and Emission Limits for Radionuclides"

- WAC 246-247, "Radiation Protection--Air Emissions"

- WHC-SD-WM-DRD-012, Design Requirements Document for the Interim Storage Phase I Solidified High-Level Waste Function 4.2.4.1.2 (Calmus 1996)

- HNF-SD-465-DRD-001, Design Requirements Document for ILAW Interim Storage (Burbank 1997)

- DE-AC06-96RL13308, TWRS Privatization Contract (RL 1996a)

- DE-AC06-96RL13309, TWRS Privatization Contract (RL 1996b).

4.2.1.10 TWRS Management Support Project. This section is based on the TWRS baseline as of June 1, 1998. Following selection of the privatization contractor, this information will be updated to reflect the contractor's process and interface with the rest of the TWRS process.

4.2.1.10.1 Project Description Summary. The TWRS Management Support Project provides overall program management to establish and maintain technical, cost, and schedule elements of the TWRS baseline, and to render services and oversight that sustain TWRS integration and control. Primary Management Support Project functions include executive management and strategic planning; systems engineering to support risk and decision management and ongoing evolution of the TWRS technical bases; administration of a core program and crosscutting services to ensure environmental, safety, health, and quality assurance compliance to all regulatory and contractual requirements applicable for TWRS; and project control.

Drivers for work indicated include the Hanford Federal Facility Agreement and Consent Order (Ecology et al. 1996); DOE Order 430.1 (DOE 1995c); DNFSB Recommendation 92-4 Implementation Plan (DNFSB 1992c); the Price-Anderson Amendments Act of 1988; 10 CFR 835; 10 CFR 830.120; DOE Order 5700.6C (DOE 1991b); and others named in the TWRS S/RM (Biebesheimer 1996) (notably those related to safety, health, quality, and the environment). The Management Support Project monitors the ongoing systems engineering analysis of TWRS functions and requirements to identify emerging needs for work products that may compel a change in Management Support System planning. The project will exist only until 2005 (when the Waste Storage Program ends), after which the need for integrated management of TWRS will be reduced. Management Support Project activities planned to occur after 2005 will transition to the Waste Retrieval Project.

4.2.1.10.2 Geographic Requirements/Assumptions. The TWRS Management Support Project is a management and integration project that does not have facility or operation responsibilities. It supports the other projects in meeting their geographic requirements/assumptions. 
4.2.1.10.3 Material and Waste Flow Requirements/Assumptions. The TWRS Management Support Project is a management and integration project that does not have material and waste flow responsibilities.

4.2.1.10.4 Facility Life-Cycle Requirements/Assumptions. The TWRS Management Support Project is a management and integration project that does not have facility or operation responsibilities.

4.2.1.10.5 Project Safety Authorization Basis/NEPA and Permits. The TWRS Management Support Project is a management and integration project that does not have facility or operation responsibilities. The TWRS Management Support Project does not require a Safety Authorization Basis.

\subsection{Other Requirements and Planning Assumptions, Including DNFSB.}

- The project will end in FY 2005 and all remaining management activities will be turned over to the Process Waste Support Project.

\subsection{Interfaces.}

\begin{tabular}{|l|c|l|}
\hline \multicolumn{1}{|c|}{ Project title } & Project number & \multicolumn{1}{c|}{ Interface } \\
\hline $\begin{array}{l}\text { Tank Waste } \\
\text { Characterization }\end{array}$ & RL-TW01 & $\begin{array}{l}\text { Provides management, budgeting, and cost reporting support. } \\
\text { Cooperates in outyear planning. }\end{array}$ \\
\hline $\begin{array}{l}\text { Tank Safety Issue } \\
\text { Resolution }\end{array}$ & RL-TW02 & $\begin{array}{l}\text { Provides management, budgeting, and cost reporting support. } \\
\text { Cooperates in outyear planning. }\end{array}$ \\
\hline $\begin{array}{l}\text { Tank Farm } \\
\text { Operations }\end{array}$ & RL-TW03 & $\begin{array}{l}\text { Provides management, budgeting, and cost reporting support. } \\
\text { Cooperates in outyear planning. }\end{array}$ \\
\hline Retrieval & RL-TW04 & $\begin{array}{l}\text { Provides management, budgeting, and cost reporting support. } \\
\text { Cooperates in outyear planning. }\end{array}$ \\
\hline $\begin{array}{l}\text { Project Waste } \\
\text { Support }\end{array}$ & RL-TW05 & $\begin{array}{l}\text { Provides management, budgeting, and cost reporting support. } \\
\text { Cooperates in outyear planning. } \\
\text { Turnover management activities that will continue after fiscal year 2005. }\end{array}$ \\
\hline Privatization Phase I & RL-TW06 & $\begin{array}{l}\text { Provides management, budgeting, and cost reporting support. } \\
\text { Cooperates in outyear planning. }\end{array}$ \\
\hline Privatization Phase II & RL-TW07 & $\begin{array}{l}\text { Provides management, budgeting, and cost reporting support. } \\
\text { Cooperates in outyear planning. }\end{array}$ \\
\hline $\begin{array}{l}\text { Privatization } \\
\text { Infrastructure }\end{array}$ & RL-TW08 & $\begin{array}{l}\text { Provides management, budgeting, and cost reporting support. } \\
\text { Cooperates in outyear planning. }\end{array}$ \\
\hline $\begin{array}{l}\text { Immobilized Tank } \\
\text { Waste Storage \& } \\
\text { Disposal }\end{array}$ & RL-TW09 & $\begin{array}{l}\text { Provides management, budgeting, and cost reporting support. } \\
\text { Cooperates in outyear planning. }\end{array}$ \\
\hline
\end{tabular}


The Waste Management Program will provide solid waste, liquid waste, and Analytical Laboratory support as defined in the most recent approved revision of the solid waste, liquid waste, and Analytical Laboratory Services forecasts.

4.2.1.10.8 Logic Diagram. Not applicable.

4.2.1.10.9 Requirements References. Not applicable. 
DOE/RL-97-55

Revision 0

January 30, 1998

\section{Waste Management Project}

Concurrence: Original signed by C.G. Mattsson Approved by: Original signed by C.A. Hansen on January 30, 1998

C. G. Mattsson, Project Director, Waste Management, Fluor Daniel Hanford, Inc. on January 30, 1998

C. A. Hansen, Office of Assistant Manager for Waste Management, U.S. Department of Energy, Richland Operations Office

Concurrence: Original signed by R, F. Guercia

R. F. Guercia, Waste Program Division, U.S. Department of Energy, Richland Operations Office 


\subsubsection{Waste Management Project}

This project has the lead to ensure waste minimization programs are applied across the Hanford Site in accordance with DOE/RL-91-31, Hanford Site Waste Minimization and Pollution Prevention Program Plan (RL 1997a).

\subsubsection{Solid Waste.}

4.2.2.1.1 Project Description Summary. Since 1943, radioactive solid waste has been disposed in direct shallow land burial grounds at the DOE's Hanford Site. There are 75 burial grounds located throughout the Site in the 100,200,300, and 600 Areas. There are 28 burial grounds in the 100 Areas and 34 in the 200 Areas, and the remaining 13 are in the 300 and 600 Areas. Burial grounds have received radioactive solid wastes from all the various missions at the Hanford Site during its 50-year history. The burial grounds also have received radioactive solid waste from offsite generators. Only eight active burial grounds in the 200 Area are managed by the Waste Management Project.

The Atomic Energy Commission directed in Immediate Action Directive 0511-21 (AEC-RL 1970) on March 20, 1970, that after April 30, 1970, all Atomic Energy Commission sites would segregate "waste with known or detectable contamination of transuranium nuclides" from other types of wastes. Such wastes were to be segregated, packaged, and stored in readily retrievable, contamination-free packages for up to 20 years. After 20 years, retrievability was to continue to be possible. This policy was implemented because of the high toxicity and long half-life periods of TRU isotopes. The 20-year interim storage period was to allow time to study. the best disposal alternative. The Immediate Action Directive did not provide a detailed definition of TRU waste. Contractors to the Atomic Energy Commission implemented the policy as well as possible based on analytical data, calculations, and process knowledge.

In 1973, the segregation limit for TRU waste was given a value of $10 \mathrm{nCi} / \mathrm{g}$. This did not change waste handling practices because the amount of TRU was based on calculations and/or estimates. In 1982, the segregation limits were changed again, to $100 \mathrm{nCi} / \mathrm{g}$, which resulted in less newly generated wastes designated as TRU waste.

On May 18, 1987, the DOE issued an interpretive rule under the Atomic Energy Act of 1954 clarifying DOE obligations under RCRA, which is promulgated in Washington State by WAC 173-303, "Dangerous Waste Regulations." As a result, all radioactive LLW contaminated with dangerous waste under the WAC is termed MLLW and subject to regulation by the DOE and Ecology. This created categories of waste that require separate waste management disposition and segregation. In 1987, the Hanford Site stopped routinely disposing of mixed waste in unlined trenches and began to store these wastes in above-ground facilities.

As part of the dangerous waste regulations, the Hanford Site was required to (1) submit permits for operation of those burial grounds which would remain active, and (2) manage regulated waste. The burial grounds for which permits were submitted are 218-E-10, 218-E-12B, 
218-W-3A, 218-W-3AE, 218-W-4B, 218-W-4C, 218-W-5, and 218-W-6 (future site). All other burial grounds at the Hanford Site are considered inactive and will be remediated under CERCLA as part of the ER Project.

4.2.2.1.2 Geographic Requirements/Assumptions. The Hanford Strategic Plan (RL 1996c) identifies the following goals for the Central Plateau (the geographic area in which most of the Solid Waste Subproject activities are performed).

\section{Requirements:}

- Retrievably stored TRU waste will be retrieved, processed, and shipped offsite to the Waste Isolation Pilot Plant (WIPP).

- Low-level waste and MLLW from onsite and offsite sources will continue to be stored and disposed in the 200 Area.

\section{Planning Assumptions:}

- The 200 Areas and Central Plateau will be used for the management of NM, the collection, treatment, and disposal of waste materials that remain onsite, and for other related and compatible uses. Cleanup levels and disposal standards will be established that are consistent with these long-term uses.

- The Solid Waste Subproject will support these goals by dispositioning solid waste consistent with national policies for management of TRU waste, LLW, MLLW, and hazardous wastes. The Hanford Site will continue to receive onsite and offsite wastes for disposal and treatment in the 200 Area.

\subsection{Material and Waste Flow Requirements/Assumptions. The Solid Waste} Subproject will identify the solid radioactive, nonradioactive hazardous, and mixed waste inventory. The solid waste data will be tracked through transfer, receipt, storage, treatment, and disposition. The Solid Waste Subproject will provide these services as necessary to the various waste generators. The following table presents a summary of the waste categories, functions, and handling process with which the Solid Waste Subproject must concern itself.

\begin{tabular}{|l|l|}
\hline \multicolumn{1}{|c|}{ Requirements } & \multicolumn{1}{|c|}{ Planning assumptions } \\
\hline $\begin{array}{l}\text { Maintain capability to } \\
\text { disposition hazardous } \\
\text { solid waste }\end{array}$ & $\begin{array}{l}\text { A contract is maintained with an offsite organization to pick up and remove from the } \\
\text { Hanford Site all nonradioactive hazardous (dangerous) solid waste. }\end{array}$ \\
\hline $\begin{array}{l}\text { Maintain capability to } \\
\text { disposition solid LLW }\end{array}$ & $\begin{array}{l}\text { Approximately } 130,000 \mathrm{~m}^{3} \text { of solid LLW are yet to be generated by various onsite and } \\
\text { offsite sources (life cycle). The Solid Waste Subproject will accept these wastes in } \\
\text { accordance with the waste acceptance criteria in effect at the time of shipment to the } \\
\text { subproject. Disposal will be provided for in the } 200 \text { Areas. }\end{array}$ \\
\hline
\end{tabular}




\begin{tabular}{|l|l|}
\hline \multicolumn{1}{|c|}{ Requirements } & \multicolumn{1}{c|}{ Planning assumptions } \\
\hline $\begin{array}{l}\text { Maintain capability to } \\
\text { disposition solid MLLW }\end{array}$ & $\begin{array}{l}\text { Currently, the Solid Waste Subproject is storing more than } 8,500 \mathrm{~m}^{3} \text { (more than } 23,000 \\
\text { containers) of MLLW awaiting treatment and disposal. More than } 60,000 \mathrm{~m}^{3} \text { of MLLW } \\
\text { are forecasted to be generated (life cycle). The Solid Waste Subproject will accept these } \\
\text { newly generated wastes in accordance with the waste acceptance criteria in effect at the } \\
\text { time of shipment to the subproject. Any newly generated wastes received by the } \\
\text { subproject will be maintained in storage until such time as treatment and/or disposal } \\
\text { capability is brought on line. Acceptance of waste is predicated upon continuing receipt } \\
\text { of treatment funding. }\end{array}$ \\
\hline $\begin{array}{l}\text { Maintain capability to } \\
\text { disposition solid TRU } \\
\text { and MTRU }\end{array}$ & $\begin{array}{l}\text { Currently, the Solid Waste Subproject has more than } 15,000 \mathrm{~m}^{3} \text { of TRU and MTRU in } \\
\text { retrievable storage that it is planning to retrieve and process for final disposal. } \\
\text { Furthermore, more than 1,000 } \mathrm{m}^{3} \text { of stored TRU and MTRU and approximately } 8,000 \mathrm{~m}^{3} \\
\text { of TRU and MTRU forecasted to be shipped to the subproject are assumed to need } \\
\text { processing for final disposal. Final disposal is assumed to be at WIPP. Acceptance of } \\
\text { waste is predicated upon continuing receipt of treatment funding. }\end{array}$ \\
\hline
\end{tabular}

LLW = low-level waste

MLLW $=$ mixed low-level waste

MTRU $=$ mixed transuranic

TRU = transuranic

WIPP $=$ Waste Isolation Pilot Plant

The Solid Waste Subproject will transfer secondary waste streams generated by activities (such as liquid effluents) for disposition on the Hanford Site.

\subsection{Facility Life-Cycle Requirements/Assumptions.}

Requirements: The following table identifies life-cycle responsibilities for the major portions of the Solid Waste Subproject. The Hanford Site Technical Baseline Database uses these data to define interfaces between Hanford Site projects. The life-cycle phases are those identified in DOE Order 430.1, Life-Cycle Asset Management (DOE 1995c).

\begin{tabular}{|c|c|c|c|c|c|c|c|c|c|}
\hline \multirow{3}{*}{ Major facility } & \multicolumn{9}{|c|}{ Life cycle } \\
\hline & \multirow{2}{*}{$\begin{array}{l}\text { Program } \\
\text { planning }\end{array}$} & \multirow{2}{*}{$\begin{array}{c}\text { Pre- } \\
\text { conceptual }\end{array}$} & \multirow[b]{2}{*}{ Conceptual } & \multicolumn{3}{|c|}{ Execute } & \multirow[b]{2}{*}{ O\&M } & \multicolumn{2}{|c|}{ Close out } \\
\hline & & & & Design & Construct & Tumover & & $\begin{array}{c}\text { Post- } \\
\text { operations }\end{array}$ & D\&D \\
\hline $\begin{array}{l}\text { T Plant Canyon } \\
(221-\mathrm{T})\end{array}$ & $\begin{array}{l}\text { RL-WM04 } \\
\text { RL-WM03 }\end{array}$ & -- & -- & $\cdots$ & - & -- & $\begin{array}{l}\text { RL-WM04 } \\
\text { RL-WM03 }\end{array}$ & $\begin{array}{l}\text { RL-WM04 } \\
\text { RL-TP10 } \\
\text { RL-WM03 }\end{array}$ & RL-ER06 \\
\hline $\begin{array}{l}2706-T \\
\text { Decontamination } \\
\text { Facility }\end{array}$ & RL-WM04 & -- & $\cdots$ & $\cdots$ & $\cdots$ & -- & RL-WMO4 & $\begin{array}{l}\text { RL-WM04 } \\
\text { RL-TP10 } \\
\text { RL-ER05 }\end{array}$ & $\begin{array}{l}\text { RL-ER06 } \\
\text { RL-ER07 }\end{array}$ \\
\hline M-91 scope & RL-WM04 & $\begin{array}{c}\text { RI. } \\
\text { WM04 }\end{array}$ & RL-WM04 & RL-WMO4 & RL-WM04 & RL-WM04 & RL-WM04 & $\begin{array}{l}\text { RL-WM04 } \\
\text { RL-TP10 }\end{array}$ & RL-ER06 \\
\hline WRAP I & RL-WM04 & -- & -- & $\cdots$ & - & -- & RL-WM04 & $\begin{array}{l}\text { RL-WM04 } \\
\text { RL-TP10 }\end{array}$ & RL-ER06 \\
\hline $\begin{array}{l}\text { MLLW Stabilization } \\
\text { Treatment Program }\end{array}$ & RI-WM04 & $\cdots$ & $=$ & -- & $\cdots$ & -- & -- & $\cdots$ & + \\
\hline
\end{tabular}




\begin{tabular}{|c|c|c|c|c|c|c|c|c|c|}
\hline \multirow{3}{*}{ Major facility } & \multicolumn{9}{|c|}{ Life cycle } \\
\hline & \multirow{2}{*}{$\begin{array}{l}\text { Program } \\
\text { planning }\end{array}$} & \multirow{2}{*}{$\begin{array}{c}\text { Pre- } \\
\text { conceptual }\end{array}$} & \multirow[b]{2}{*}{ Conceptual } & \multicolumn{3}{|c|}{ Execute } & \multirow[b]{2}{*}{ O\&M } & \multicolumn{2}{|c|}{ Close out } \\
\hline & & & & Design & Construct & Turnover & & $\begin{array}{c}\text { Post- } \\
\text { operations }\end{array}$ & $\mathrm{D} \& \mathrm{D}$ \\
\hline $\begin{array}{l}\text { Commercial thermal } \\
\text { treatment scope }\end{array}$ & RL-WM04 & -- & $\cdots$ & $\cdots$ & -- & $\cdots$ & -. & - & -- \\
\hline cwc & RL-WM03 & -- & - & - & -- & $\cdots$ & RL-WM03 & RL-WMO3 & $\begin{array}{l}\text { RL-ER06 } \\
\text { RL-ER07 }\end{array}$ \\
\hline $\begin{array}{l}\text { Low-Level Burial } \\
\text { Grounds }\end{array}$ & RL-WM03 & $\cdots$ & -- & - & $\cdots$ & -- & RL-WM03 & RL-WM03 & $\begin{array}{l}\text { RL-ER02 } \\
\text { RL-ER07 }\end{array}$ \\
\hline $\begin{array}{l}\text { Nonradioactive } \\
\text { Dangerous Waste } \\
\text { Storage Facility }\end{array}$ & RL-WM03 & $\ldots$ & - & -- & -. & - & -- & RL-WM03 & $\begin{array}{l}\text { RL-ER06 } \\
\text { RL-ER07 }\end{array}$ \\
\hline TRUSAF & RL-WM03 & $\begin{array}{l}\text { RL- } \\
\text { WM03 }\end{array}$ & RL-WM03 & RL-WM03 & RL-WM03 & RL-WM03 & RL-WM03 & $\begin{array}{l}\text { RL-WM03 } \\
\text { RL-TP10 } \\
\text { RL-ER05 }\end{array}$ & $\begin{array}{l}\text { RL-ER06 } \\
\text { RL-ER07 }\end{array}$ \\
\hline $\begin{array}{l}\text { Mixed waste } \\
\text { disposal structures }\end{array}$ & RL-WM03 & -- & $\cdots$ & -- & - & $\cdots$ & RL-WM03 & $\begin{array}{l}\text { RL-WM03 } \\
\text { RL-TP10 }\end{array}$ & RL-ER06 \\
\hline $\operatorname{csB}^{*}$ & $\begin{array}{c}\text { CSB } \\
\text { RL-WM02 }\end{array}$ & -- & $\cdots$ & $-\cdot$ & -- & $\operatorname{CsB}$ & RL-WM03 & $\begin{array}{c}\text { CSB } \\
\text { RL-TP10 }\end{array}$ & RL-ER06 \\
\hline $\begin{array}{l}\text { Solid Waste } \\
\text { infrastructure }\end{array}$ & RL-WM03 & $\cdots$ & - & -. & -- & $\cdots$ & RL-WM03 & $\begin{array}{l}\text { RL-WM03 } \\
\text { RL-TP10 }\end{array}$ & RL-ER06 \\
\hline
\end{tabular}

*The programmatic responsibility for O\&M and D\&D of the CSB is still an open issue.

$\mathrm{CSB}=$ Canister Storage Building portion of the Solid Waste Subproject

CWC $=$ Central Waste Complex

$\mathrm{D \& D}=$ decontamination and decommissioning

MLLW = mixed low-level waste

O\&M = operations and maintenance

TRUSAF $=$ Transuranic Waste Storage and Assay Facility

WRAP $=$ Waste Receiving and Processing

\section{Planning Assumptions:}

- None.

4.2.2.1.5 Key Technical Requirements. The Solid Waste Subproject was established to manage the solid wastes at the Hanford Site. Waste moves into the Solid Waste Subproject for storage and/or treatment before final dispositioning (either onsite disposal [as in the case of LLW] or offsite dispositioning [as in the case of plans for TRU]). The primary technical requirements for the major portions of the Solid Waste Subproject noted in Section 4.2.2.1.4 follow.

4.2.2.1.5.1 T Plant Canyon (221-T). The 221-T Facility is used for storage, sampling, and limited treatment of radioactive mixed and dangerous waste. However, it functions primarily as a treatment/decontamination and waste storage facility. 
In addition to decontamination services, $\mathrm{T}$ Plant provides for the storage of Shippingport Pressurized Water Reactor (PWR) Core II fuel and the storage of higher-activity radioactive mixed waste in the canyon.

\section{Requirements:}

- The 221-T Facility operates under Consent Order No. DE91NM-177 (Ecology and DOE 1991) for the Permitting of Liquid Effluent Discharges under WAC 173-216, "State Waste Discharge Permit Program." The permit is dated February 1992.

- The facility is included in the Hanford Facility Part A Dangerous Waste Permit Application Form 3, Rev. 6, for the T Plant Complex (TSD: T-2-7) (October 1, 1996). Part B was submitted in 1995 as DOE/RL-95-36, The Hanford Facility Dangerous Waste Permit Application T Plant Complex (RL 1995a).

\section{Planning Assumptions:}

- Because of the uncertainty of committed waste volume projections, future expenditures to maintain the capability to perform high-volume liquid decontamination capability in the 221-T Canyon are not justified at this time.

- The 221-T Canyon provides services in radioactive and hazardous constituent decontamination of waste items and process equipment on a case-by-case basis.

4.2.2.1.5.2 2706-T Decontamination Facility. The 2706-T Building was built during 1959 and 1960 to perform low-level radioactive decontamination.

\section{Requirements:}

- The 2706-T Building operates under Consent Order No. DE91NM-177 (Ecology and DOE 1991) for the Permitting of Liquid Effluent Discharges under WAC 173-216, "State Waste Discharge Permit Program." The permit is dated February 1992.

- The building is included in the Hanford Facility Part A Dangerous Waste Permit Application Form 3, Rev. 6, for the T Plant Complex (TSD: T-2-7) (October 1, 1996). Part B was submitted in 1995 as DOE/RL-95-36, The Hanford Facility Dangerous Waste Permit Application T Plant Complex (RL 1995a).

\section{Planning Assumptions:}

- The 2706-T Building will serve as the centralized decontamination facility. Safety analysis reports, procedures, and permit upgrades will increase facility limits to those of a fissile facility, allowing the 2706-T Building to process a large percentage of the forecasted T Plant feedstreams. 
- The 2706-T Building operates as a low-level radioactive decontamination facility and is used to decontaminate railroad equipment, buses, trucks, automobiles, road-building equipment, and plant process equipment.

- The 2706-T Building is restricted to radioactive LLW associated with decontamination activities. It also is used as a site to characterize radioactive LLW and mixed wastes.

In addition to decontamination services, the following activities are performed at the 2706-T Building.

- Waste repackaging, characterization, and certification are performed in compliance with regulations.

- Low-level waste boxes and drums can be received, opened, sorted, segregated, and repackaged. Verification of container contents can be provided as necessary. Sorting and segregation of unknown or poorly characterized waste allow for the proper characterization of wastes.

\subsection{Scope of Milestone M-91-00.}

\section{Requirements:}

- The hazardous, radioactive MLLW will be treated to meet the Hanford Site Solid Waste Acceptance Criteria (WAC) (Willis 1993) for disposal of MLLW.

- The TRU and mixed transuranic (MTRU) waste processed will meet transuranic package transporter (TRUPACT) II shipping requirements and the WIPP WAC for disposal at WIPP.

- The WIPP will receive TRU waste from the Milestone M-91-00-defined facility(ies).

\section{Planning Assumptions:}

- Transuranic processing will take place in a separate facility or in separate campaigns from MLLW processing to avoid cross-contamination of waste.

- The Milestone M-91-00-defined processing facility(ies) will provide treatment for Hanford Site solid wastes determined to be remote-handled (RH) MLLW; oversized (larger than 1.8 by 2.4 by $3.7 \mathrm{~m}$ ) contact-handled $(\mathrm{CH})$ hazardous, radioactive MLLW; RH TRU waste; oversized CH TRU waste (larger than a standard waste box); and CH TRU waste that requires special processing that the 2336-W Facility (Waste Receiving and Processing [WRAP]) cannot provide.

4.2.2.1.5.4 WRAP (2336-W Facility). The 2336-W Facility will receive retrieved and newly generated solid $\mathrm{CH}$ radioactive wastes. The majority of the waste that the $2336-\mathrm{W}$ Facility will process will be in drums that have capacities less than or equal to $208 \mathrm{~L}$ (some will be 
overpacked in salvage drums). Drums will be inspected, assayed, and opened if necessary. Waste contents can be sorted and segregated, and empty drums and wastes compacted as appropriate, repackaged, certified, and shipped to final disposal.

\section{Requirements:}

- The TRU and MTRU waste processed will meet TRUPACT I shipping requirements and the WIPP WAC (Mayancsik 1994).

- The WTPP will receive waste from WRAP until 2031.

\section{Planning Assumptions:}

- The 2336-W Facility will have an operating life extending from FY 1998 to FY 2031.

- The 2336-W Facility will operate on a one-shift-per-day basis.

- The design capacity of WRAP is as follows: a total of 6,825 drums of $\mathrm{CH}$ waste received annually. This includes 2,100 drums of newly generated TRU and MTRU waste, 2,625 drums of retrieved suspect TRU, and 2,100 drums of newly generated LLW and MLLW. The facility shall also receive, certify, and ship 70 standard waste boxes of CH TRU annually (Mayancsik 1994).

- The 2,100 drums of newly generated TRU and MTRU waste consist entirely of TRU and MTRU waste (Mayancsik 1994).

- The 2,625 drums of retrieved suspect TRU consist of 50\% TRU and 50\% LLW (Mayancsik 1994).

- The 2,100 drums of newly generated LLW and MLLW consist entirely of LLW and MLLW (Mayancsik 1994).

4.2.2.1.5.5 MLLW Stabilization Treatment Program. The Program is divided into three treatment option categories: direct disposal, onsite treatment, and commercial treatment. Each of these three categories have independent value. Many studies, evaluations, and reports led to the current formulation of the Program, including the following: WHC-SD-W100-RPT-001, Waste Receiving and Processing Module $2 A$ Termination of Design Closeout Report (Carlson 1995); WHC-EP-0063-4, Hanford Site Solid Waste Acceptance Criteria (Willis 1993); WHC-SD-W100RD-001, Waste Receiving and Processing Module $2 A$ Feed Specification (Kruger 1994); DOE/RL-95-35, Direct Disposal Team Report - Options for Treating and Disposing of Current and Future Mixed Waste Streams on the Hanford Facility (RL 1995b).

\section{Requirements:}

- The MLLW Stabilization Treatment Program was put into place to replace the treatment void created by Waste Receiving and Processing Module 2A (WRAP 2A) 
design termination. The Program delineates how and where the waste will be treated to meet Tri-Party Agreement Milestone M-91-00 obligations. A Tri-Party Agreement milestone change was obtained to clarify the new direction for treating subject waste.

- Waste to be treated under the MLLW Stabilization Treatment Program is designated as CH MLLW Category I and Category III as defined in WHC-EP-0063-4 (Willis 1993). The waste is further segregated to include only non-thermally treatable waste under the scope of this program. The thermally treatable portion is under the Commercial Thermal Treatment scope (see Section 4.2.2.1.5.6).

\section{Planning Assumptions:}

- Direct Disposal--Pursues the regulatory strategies and positions allowing for direct disposal of some mixed waste that was previously identified as requiring treatment. This is to be done through treatment variances, verifying that waste currently meets land disposal restrictions (LDR) or petition acceptance of existing treatment performed on some waste.

- Onsite Noncommercial Treatment--Pursues the capability to treat some mixed waste at the Hanford Site using the established work force and facilities.

- Commercial Treatment--Pursues the capability to procure commercial mixed waste stabilization treatment services. The scope and requirements of the Program's commercial mixed waste stabilization treatment activity will be represented in various RFPs for procuring commercial stabilization treatment services. This service has the option to commercially treat the waste off or on the Hanford Site.

\subsection{Commercial Thermal Treatment Scope. The scope of the Commercial} Thermal Treatment service contract requires the thermal treatment contractor to transport the waste to its thermal treatment facility, thermally treat the waste, and produce a stabilized final waste form certified for disposal. The thermal treatment technology proposed by the contractor will produce a glass/slag final waste form for the combustible portion of the waste. The non-combustible portion of the waste will either be microencapsulated or macroencapsulated. The thermal treatment contractor will be responsible for meeting all regulatory requirements regarding waste transportation, waste treatment, waste analysis, and waste disposal certification. The thermal treatment contractor will transport the final waste form to the Hanford Site where it will be disposed. In addition to supporting Tri-Party Agreement M-91-00, this contract also will show compliance with the national consent order between the DOE and the U.S. Environmental Protection Agency regarding polychlorinated biphenyls (PCB).

Various reports, studies, and evaluations have been completed as the commercial thermal treatment option has come to fruition. These have included the following: WHC-SD-W242HC-001, Hazard Classification for the Thermal Treatment Facility, Project W-242. (Cillan 1993); Purchase Order No. MW6-SBV-357079, "Thermal Treatment Services;" WHC-SD-WM-ES-198, Assessment of High Temperature Thermal Treatment Alternatives for Inclusion Into the Scope of the Hanford WRAP Facility (Place 1991); Internal Memorandum, Thermal Treatment of 
Hanford's RMW - Summary Discussion of Vendor Capabilities (Place 1992); WHC-SD-W242ES-001, Hanford Site-Specific Engineering Study for the W-242 Thermal Treatment Facility (Place 1993); Contract No. MLW-SVV-073750, Task S-92-21, Treatment of Hanford's Mixed Waste Streams by INEL's Thermal Treatment Facilities (SAIC 1992); Contract No. MLW-SVV-073750, Task S-93-28, Treatment of Hanford RMW Streams by INEL's Waste Experimental Reduction Facility (WERF) Incinerator (SAIC 1993); and WHC-EP-0063-4, Hanford Site Solid Waste Acceptance Criteria (Willis 1993).

\section{Requirements:}

- The radioactive constituents in the waste are regulated by DOE Order $5820.2 \mathrm{~A}$ (DOE 1988c), which pertains to the management of LLW. The hazardous components in the waste are regulated by RCRA, WAC, and the Toxic Substances Control Act of 1976 (TSCA) and by the RCRA and TSCA implementing regulations contained in 40 CFR, "Protection of the Environment." The treatment criteria specified in 40 CFR 268, "Land Disposal Restrictions," and 40 CFR 761.70, "Incineration of PCBs and PCB Items," must be met.

- The treatment process shall generate a stabilized, solid ash/residue final waste form. The WAC requirements are defined in WAC-173-303. All ash/residue resulting from thermal treatment of the waste shall be packaged and returned to the Hanford Site for disposal in accordance with WHC-EP-0063-4, Hanford Site Solid Waste Acceptance Criteria (Willis 1993) and U.S. Department of Transportation (DOT) Regulations (49 CFR 171-179, "Hazardous Materials Regulations").

- Air emissions from the Commercial Thermal Treatment facility will be in compliance with 40 CFR Part 61, "National Emission Standards for Hazardous Air Pollutants." An application for approval under 40 CFR 61.07 may be required for new facility construction. The application shall include technical information describing the proposed nature, size, design, operating design capacity, and method of operation of the source, including a description of any equipment to be used for control of emissions.

- Meeting the above regulatory concerns will primarily be the responsibility of the thermal treatment contractor.

\section{Planning Assumptions:}

- Provide treatment for MLLW by thermal destruction of the hazardous constituents and subsequent immobilization of the radionuclides in a grouted or slag/glass final waste form. Provide treatment for alpha-contaminated PCB wastes regulated by the TSCA and for most listed and characteristic hazardous wastes restricted from land disposal under RCRA. In addition to TSCA-regulated PCBs, a significant quantity of radioactive mixed waste containing RCRA F-coded, ignitable, and reactive organic constituents is presently stored or will be generated at the Hanford Site. Thermal destruction is required for TSCA-regulated PCBs, and it is the best demonstrated 
available (treatment) technologies for RCRA LDR wastes. Treatment is scheduled to begin by December 2000 .

4.2.2.1.5.7 Central Waste Complex (CWC). The CWC is an existing and planned series of facilities to centralize the management of solid waste operations at the Hanford Site. The CWC consists of multiple structures for storage of radioactive or mixed waste before the waste is processed or certified for final disposal. The CWC provides the capacity.to store onsite and offsite waste. Storage of waste began in 1988. Currently, the CWC consists of the following:

- 3 mixed waste storage buildings (Buildings 2404-WA, WB, and WC)

- 27 low-flashpoint mixed waste storage modules

- 13 mixed waste storage facilities (Buildings 2401-W, 2402-W, and 2402-WB through -WL)

- 4 mixed waste storage facilities (Buildings 2403-WA through 2403-WD)

- 4 alkali metal waste storage modules (for storing waste $\mathrm{Na}$ )

- 8 south alkali metal storage modules (for storing product $\mathrm{Na}$ )

- 1 waste receiving and staging area

- 1 mixed waste storage pad. ${ }^{1}$

\section{Requirements:}

- The CWC provides receipt and storage for radioactive and mixed solid waste from various onsite and offsite waste generators. The $\mathrm{CWC}$ waste types and interfaces and a description of the various buildings are provided in the following sections.

- The solid wastes that will be handled at the CWC include currently stored and newly generated MLLW, TRU waste, and MTRU waste. The CWC also includes a small quantity of LLW that cannot meet disposal requirements. The CWC is designed and authorized exclusively for receipt and storage of $\mathrm{CH}$ waste packages. Contacthandled waste packages have a surface dose rate of $<2 \mathrm{mSv} / \mathrm{h}$. Although packages up to $2 \mathrm{mSv} / \mathrm{h}$ can be stored at the $\mathrm{CWC}$, an operational limit of $1 \mathrm{mSv} / \mathrm{h}$ is imposed.

${ }^{1}$ One Product Sodium Storage Building (the 2727-W Building). The alternate responsibility for the 2727-W Building and the $\mathrm{Na}$ it contains is not yet finalized. The Solid Waste Subproject provides surveillance of this facility. 


\section{Planning Assumptions:}

- The CWC has the capacity to store nominally 80,000 208-L drum equivalents of containerized waste.

4.2.2.1.5.8 Low-Level Burial Grounds. The Low-Level Burial Grounds provide disposal capability for Category I and Category III LLW.

\section{Requirements:}

- DOE/RL-88-20, Low-Level Burial Grounds Dangerous Waste Permit Application and DOE-RL 88-20, Supplement 1, Low-Level Burial Grounds Dangerous Waste Permit Application: Request for Exemption from Lined Trench Requirements for Submarine Reactor Compartments (DOE-RL 1988)

- WHC-EP-0063-4, Hanford Site Solid Waste Acceptance Criteria (Willis 1993)

- WHC-EP-0558, Test and Evaluation Document for DOT Specification $7 A$ Type A Packaging (Kelly 1996)

- WHC-SD-WM-ISB-002, Solid Waste Burial Grounds Interim Safety Basis (Bendixsen 1995)

- WAC 173-303, "Dangerous Waste Regulations"

- 40 CFR 141, "National Primary Drinking Water Regulations"

- RCRA and as amended by the Hazardous and Solid Waste Amendments of 1984

- DOE Order 5820.2A, Radioactive Waste Management (DOE 1988c).

\section{Planning Assumptions:}

- The Solid Waste Subproject disposes of Category I and Category III LLW in the 200 Area burial grounds.

- The capacity of the disposal system can accommodate all forecasted Category I and Category III LLW.

4.2.2.1.5.9 Nonradioactive Dangerous Waste Storage Facility (616). The Nonradioactive Dangerous Waste Storage Facility began operation in September 1986. The facility is classified as container storage. This facility provides a centralized storage unit to receive, store, and prepare shipments of nonradioactive dangerous waste. Before receipt, waste is characterized, designated according to Ecology regulations, and packaged according to DOT regulations. 
Waste is received and placed in the appropriate storage cell awaiting shipment offsite. After waste is sufficiently accumulated to warrant offsite shipment, it is manifested and inspected for offsite shipment and transported to a permitted TSD facility.

\section{Requirements:}

- None in the inactive mode.

\section{Planning Assumptions:}

- The 616 Building is inactive, and is being maintained in a "hot standby" mode. Should dangerous wastes need to be received directly by the Solid Waste Subproject this facility could be reactivated. The 616 Building is scheduled to be transferred to the Facility Transition Project in 2001.

4.2.2.1.5.10 Transuranic Waste Storage and Assay Facility (TRUSAF) (Part of 224-T). Functions that can be performed at the TRUSAF include the exterior container inspection, real-time radiography inspection, neutron assay for fissile material content, and interim storage in facility storage modules. These can be classified as shipping/receiving, waste handling, storage, inspection, and segregation.

\section{Requirements:}

- WHC-SD-WM-ISB-004, Transuranic Waste Storage and Assay Facility Interim Safety Basis (Gibson 1995)

- DOE/RL-91-51, 224-T Transuranic Waste Storage and Assay Facility Dangerous Waste Permit Application (DOE/RL 1992).

\section{Planning Assumptions:}

- WHC-EP-0363, Solid Waste Management Program Plan (Duncan 1991).

4.2.2.1.5.11 Mixed Waste Disposal Structures. The Radioactive Mixed Waste Disposal Facility will provide permanent disposal capability for MLLW.

\section{Requirements:}

- Each disposal system will have a design life of 50 years minimum; 20 years are required for the operational phase and 30 years for post-closure monitoring.

- The Radioactive Mixed Waste Disposal system will meet the minimum functional standards for a dangerous waste landfill as required by WAC 173-303, "Dangerous Waste Regulations." 
- The trenches will provide permanent disposal capacity for MLLW that has been treated to meet the LDR.

\section{Planning Assumptions:}

- Two disposal trenches have been constructed in Burial Ground 218-W-5 for radioactive mixed waste disposal, and additional trenches can be constructed as needed.

- The capacity of each of the two existing radioactive mixed waste trenches is approximately $27,000 \mathrm{~m}^{3}$ of waste in containers, but will vary depending on the waste package configuration and fill/capping strategy.

- Additional disposal capacity will be built in the future as demand requires.

4.2.2.1.5.12 CSB (212-H). Refer to Section 4.2.3.5.2 for details.

4.2.2.1.5.13 Solid Waste Infrastructure. It is generally recognized that various needs, such as office space, water, electricity, etc., will be required to effectively perform the functions of the Solid Waste Subproject. These infrastructure resources will likely be received from the Site infrastructure provider(s). It is further acknowledged that a "handshake" will need to be established to effectively manage this large pool of resources.

\section{Requirements:}

- None.

\section{Planning Assumptions:}

- All necessary infrastructure items (electricity, water, roads, etc.) will be transferred in some manner to the Solid Waste Subproject as needed. Some will have costs associated with them, and some will be a part of the Hanford Site infrastructure at no added cost to Solid Waste.

\subsection{Project Safety Authorization Basis/NEPA and Permits.}

Requirements: The Solid Waste Subproject has an S/RID in place (Hamilton 1995). This S/RID is being revised to include the Liquid Waste and Analytical Services portions of the Waste Management Project.

The Authorization Basis for the Solid Waste Subproject is contained in the following:

- WHC-SD-WM-ISB-007, Central Waste Complex - Interim Safety Basis (Cain 1995)

- WHC-SD-WM-ISB-004, TRUSAF Interim Safety Basis (Gibson 1996) 
DOE/RL-97-55

Revision 0

- WHC-SD-W112-SAD-001, Enhanced Radioactive and Mixed Waste Storage Phase V (Project W-112) Safety Assessment (Bonner 1995)

- WHC-SD-WM-SAR-019, Nonradioactive Dangerous Waste Storage Facility (Bodily 1993)

- HNF-SD-W026-SAR-002, Final Safety Analysis Report for Waste Receiving and Processing Facility (Weidert 1997)

- WHC-SD-CP-SAR-007, T Plant Safety Analysis Report (Johnson 1993)

- WHC-SD-WM-ISB-006, Interim Safety Basis for Solid Waste Facilities (T Plant) (Meyer 1997)

- WHC-SD-WM-SAR-058, Final Safety Analysis for Contact-Handled TRU Waste Drums In-Situ Inspection and Vented Drum Retrieval (Joyce 1994)

- WHC-SD-WM-ISB-002, Solid Waste Burial Grounds Interim Safety Basis (Bendixsen 1995).

Planning Assumptions:

- None.

\subsection{Other Requirements and Planning Assumptions.}

\section{Requirements:}

- DNFSB Recommendation 94-2, Conformance with Safety Standards at DOE Low-Level Nuclear Waste and Disposal Sites (DNFSB 1994a)

- RCRA

- TSCA.

\section{Planning Assumptions:}

- None.

4.2.2.1.8 Interfaces. The Solid Waste Subproject receives LLW, MLLW, and TRU and MTRU wastes from onsite generators. These onsite generators include SNF, Pacific Northwest, Liquid Effluents, Non-Programmatic/Landlord, Analytical Services, ER, and TWRS.

Furthermore, various offsite generators send waste to the Solid Waste Subproject. These 
generators are grouped into the categories of universities, U.S. Navy, other DOE sites, other national laboratories, and other offsite generators. Subsequently, the Solid Waste Subproject "connects up" with other organizations such as the following:

- SNF--to receive the PWR Core II fuel out of the T Plant Canyon

- TWRS--to take liquid radioactive wastes that cannot be transferred to the ETF

- Analytical Services--to have various liquid, solid, and gaseous samples analyzed

- Non-Programmatic/Landlord--to obtain services such as electrical, steam, road, janitorial, etc.

Various facilities, such as TRUSAF and the Nonradioactive Hazardous Waste Facility, subsequently will be transferred to the Transition Project and ultimately the ER Project for dispositioning.

The Waste Management Program will provide solid waste, liquid waste, and analytical laboratory support as defined in the most recent approved revision of the solid waste, liquid waste, and Analytical Laboratory Services forecasts.

4.2.2.1.9 Logic Diagram. Refer to Figure 4-3.

4.2.2.1.10 Requirements References. Refer to the Solid Waste S/RDs (Hamilton 1995).

4.2.2.1.11 Planning Assumptions. None.

\subsubsection{Liquid Waste Program.}

4.2.2.2.1 Project Description Summary. The Liquid Waste Program provides integrated liquid effluent management to support cleanup of the Hanford Site. Its mission is to responsibly manage current and future liquid effluent streams in a safe, cost-effective, and environmentally compliant manner. Waste volume reduction support is also provided to tank waste remediation. The mission is achieved through planning and integration, stakeholder interaction, definition of requirements for generators, and provision of timely TSD capability.

The Liquid Waste Program receives, treats, and disposes of liquid effluents from other projects. Waste acceptance criteria are established for liquid effluents, and compliance with discharge limits is verified. The project includes overall program management of the Liquid Waste Program and operation, maintenance, technical support, and management and administration of the following facilities: 242-A Evaporator, Liquid Effluent Retention Facility (LERF), 200 Area ETF, 200 Area Treated Effluent Disposal Facility (200 Area TEDF), 300 Area Treated Effluent Disposal Facility (300 Area TEDF), 307 Retention Basins, and 340 Waste Handling Facility. The Liquid Waste Program is responsible for operation and maintenance of the Process Sewer System, Retention Process Sewer System, and Radioactive Liquid Waste System, 
DOE/RL-97-55

Revision 0

January 30, 1998

Figure 4-3. Logic Diagram for the Solid Waste Subproject.

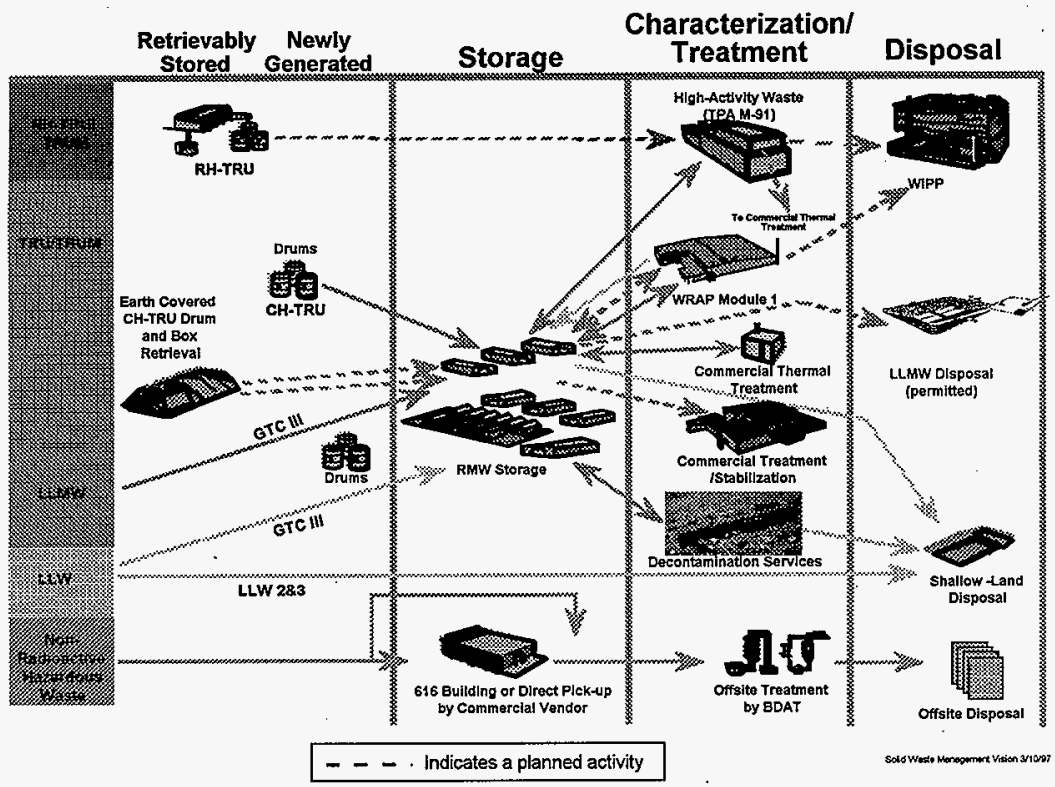

all of which are in the 300 Area. The Liquid Waste Program is also responsible for commitments identified in DOE/RL-93-94, Plan and Schedule for Dispositioned Regulatory Compliance for Miscellaneous Streams (RL 1995c); shutdown planning and integration for the 340 Waste Handling Facility; and preparation of a biennial tritium treatment technology report as required by the Tri-Party Agreement.

\subsection{Geographic Requirements/Assumptions.}

\section{Requirements:}

- Reuse facilities in the South 600 Area for economic diversification where feasible. 


\section{Planning Assumptions:}

- The Liquid Waste Program supports numerous end point targets assigned to other programs. The cleanup goals for each geographical area, and the end point targets assigned to other programs and supported by the Liquid Waste Program, are as follows.

\section{Reactors on the River}

Cleanup Goal: Remove and/or stabilize SNF, surplus facilities, and waste sites to protect groundwater and the Columbia River and to ensure protection of people, the environment, and natural and cultural resources. Pending Congressional action on the Wild and Scenic River designation, use will continue to be restricted; sensitive ecological, cultural, and Native American resources will be protected.

- Remove SNF and clean out K Basins sufficient to transition to D\&D.

- Drain, decontaminate, and stabilize the K Basins Facility.

\section{Central Plateau}

Cleanup Goal: The 200 Areas and Central Plateau will be used for the management of $\mathrm{NM}$, the collection and disposal of waste materials that remain onsite, and for other related and compatible uses. Cleanup levels and disposal standards will be established that are consistent with these long-term uses.

- Continue to restrict groundwater use for a yet-to-be-determined period. Intercept or contain groundwater to within designated boundaries.

- Operate the Environmental Restoration Disposal Facility (ERDF) to accept waste from remediation of CERCLA units across the Hanford Site.

- Continue to provide disposal in the 200 Area for LLW and MLLW (solids) from onsite and offsite sources.

- Retrieve tank wastes to the extent needed for tank closure, divide into high-level and low-activity fractions, and immobilize.

- Continue to provide safe storage for $\mathrm{Cs} / \mathrm{Sr}$ capsules in WESF indefinitely. The WESF is a decoupled and a standalone facility.

- Transition the Plutonium-Uranium Extraction (PUREX) Facility and B Plant to a low-cost, stable, deactivated condition.

- Send the Cs/Sr capsules that are declared waste to Yucca Mountain for the HLW repository. 
- Complete stabilization of plutonium (Pu) in the Plutonium Finishing Plant (PFP) (DNFSB Recommendation 94-1 [DNFSB 1994b] implementation).

- Transition production areas of the PFP to a low-cost, stable, deactivated condition; continue safe, stable, interim storage of $\mathrm{Pu}$.

\section{South 600 Area}

Cleanup Goal: The 300 Area waste sites, materials, and facilities will be remediated to allow industrial and economic diversification opportunities. The federal government will retain ownership of land in and adjacent to the 300 and 400 Areas, but will lease land for private and public uses to support regional industrial and economic development. Excess land within the 1100 Area will be targeted for transition to non-federal ownership.

- Transition high-cost surplus facilities to a low-cost, stable, deactivated condition.

- Transition the 324 and 327 Buildings to a low-cost, stable, deactivated condition and disposition their NM (including the 324 Building radioactive tank wastes).

- Complete transition of the 300 Area fuel supply.

\subsection{Material and Waste Flow Requirements/Assumptions.}

\section{Requirements:}

- The LERF and ETF can accept low-level, RCRA-regulated, mixed low-level, and CERCLA-regulated liquid effluents, and also industrial wastewaters for storage and treatment. A delisting petition was specifically approved for treating the 242-A Evaporator process condensate for waste codes F001 through F005, and F039 leachate (as derived from F001 through F005). Characteristic waste may be accepted.

- The 200 Area TEDF can accept non-RCRA liquid effluents that meet the restrictions of the WAC 173-216 discharge permit. No additional contaminants may exist in the effluent that would constitute a contaminant to the groundwater. Liquid effluents that discharge to the 200 Area TEDF have already had best available technology (BAT)/all known, available, and reasonable treatment (AKART) applied by the generator.

- The 300 Area TEDF can accept industrial wastewaters and CERCLA-regulated liquid effluents. Low-level liquid effluents may be accepted on a non-routine basis provided they can be managed such that the treated effluent does not exceed allowable discharge limits. Liquid effluents containing radioactive materials in concentrations that cannot be effectively managed, hazardous waste, and difficult-to-treat compounds are prohibited. 
- The 340 Waste Handling Facility provides receipt, storage, and loadout capability for LLW and MLLW. The waste is transported to the 204-AR Unloading Station in the 200 Area for storage in the DSTs. The DSTs can generally accept LLW, MLLW, and RCRA- and CERCLA-regulated wastes for storage.

- Miscellaneous streams include liquid effluents generated from hydrotest, maintenance, and construction activities; cooling water and condensate discharges; and storm water runoff. The inventory of the miscellaneous streams is divided into quantitative and qualitative categories. Quantitative streams discharge from a fixed location to an engineered disposal structure at a measurable flow rate. Qualitative streams are difficult to quantify due to their limited duration and/or multiple locations; they do not discharge to an engineered disposal structure.

\section{Planning Assumptions:}

- Waste volume forecast data for the Liquid Waste Program are provided in HNF-SP-1229, Waste Management Project Fiscal Year 1998 Multi-Year Program Plan, WBS 1.2 (Van Leuven and Mattsson 1997). The waste types included are hazardous waste, industrial waste, LLW, mixed waste, and treated effluent. Estimates are provided of the volumes received, generated, transferred, treated, and disposed.

\subsection{Facility Life-Cycle Requirements/Assumptions.}

\section{Requirements:}

- None.

Planning Assumptions: The following table identifies life-cycle responsibility for the major Liquid Waste Program facilities. The life-cycle phases correspond to those in DOE Order 430.1, Life-Cycle Asset Management (DOE 1995c). All the Liquid Waste Program facilities are currently operating and no new facilities are planned to be constructed.

\begin{tabular}{|c|c|c|c|c|c|c|c|c|c|}
\hline \multirow{3}{*}{ Major facility } & \multicolumn{9}{|c|}{ Life cycle } \\
\hline & \multirow{2}{*}{$\begin{array}{l}\text { Program } \\
\text { planning }\end{array}$} & \multirow{2}{*}{$\begin{array}{c}\text { Pre- } \\
\text { conceptual }\end{array}$} & \multirow[b]{2}{*}{ Conceptual } & \multicolumn{3}{|c|}{ Execute } & \multirow[b]{2}{*}{ O\&M } & \multicolumn{2}{|c|}{ Close out } \\
\hline & & & & Design & Const. & Turnover & & $\begin{array}{c}\text { Post- } \\
\text { operations }\end{array}$ & $D \& D$ \\
\hline $\begin{array}{l}242-\mathrm{A} \\
\text { Evaporator }\end{array}$ & -- & -. & $\cdots$ & $\cdots$ & -- & $\cdots$ & RL-WMOS & RL-TP10 & $\begin{array}{l}\text { RL- } \\
\text { ER06 }\end{array}$ \\
\hline LERF & -- & $\cdots$ & -- & $\cdots$ & -- & $\cdots$ & RL-WMOS & RL-TP10 & $\begin{array}{l}\text { RL- } \\
\text { ER06 }\end{array}$ \\
\hline ETF & -- & -- & -- & -- & .. & -- & RL-WMOS & RL-TP10 & $\begin{array}{l}\text { RL- } \\
\text { ER06 }\end{array}$ \\
\hline $\begin{array}{l}200 \text { Area } \\
\text { TEDF }\end{array}$ & -. & -- & -. & $\cdot \cdot$ & -. & -. & RL-WMOS & RL-TP13 & N/A \\
\hline
\end{tabular}




\begin{tabular}{|c|c|c|c|c|c|c|c|c|c|}
\hline \multirow{3}{*}{ Major facility } & \multicolumn{9}{|c|}{ Life cycle } \\
\hline & \multirow{2}{*}{$\begin{array}{l}\text { Program } \\
\text { planning }\end{array}$} & \multirow{2}{*}{$\begin{array}{c}\text { Pre- } \\
\text { conceptual }\end{array}$} & \multirow[b]{2}{*}{ Conceptual } & \multicolumn{3}{|c|}{ Execute } & \multirow[b]{2}{*}{ O\&M } & \multicolumn{2}{|c|}{ Close out } \\
\hline & & & & Design & Const. & Tumover & & $\begin{array}{c}\text { Post- } \\
\text { operations }\end{array}$ & D\&D \\
\hline $\begin{array}{l}300 \text { Area } \\
\text { TEDF }\end{array}$ & -- & $\cdots$ & -- & -- & -- & -- & RL-WMOS & RL-WM05 & N/A \\
\hline $\begin{array}{l}340 \text { Waste } \\
\text { Handling } \\
\text { Facility }\end{array}$ & $\ldots$ & -- & $\cdots$ & -- & -- & - & RL-WM05 & RL-WMOS & $\begin{array}{l}\text { RL- } \\
\text { ER06 }\end{array}$ \\
\hline $\begin{array}{l}307 \text { Retention } \\
\text { Basins }\end{array}$ & -- & $\cdots$ & $\cdots$ & -- & -- & $-\cdot$ & RL-WM05 & RL-ER06 & $\begin{array}{l}\text { RL- } \\
\text { ER06 }\end{array}$ \\
\hline $\begin{array}{l}\text { D\&D = } \\
\text { ETF = } \\
\text { LERF = } \\
\text { N/A = } \\
\text { TEDF = }\end{array}$ & $\begin{array}{l}\text { Lecontaminat } \\
\text { Effluent Trea } \\
\text { Liquid Efflue } \\
\text { Tret applicabl } \\
\text { Treated Efflu }\end{array}$ & $\begin{array}{l}\text { on and decon } \\
\text { ment Facility } \\
\text { tt Retention F } \\
\text { int Disposal F }\end{array}$ & $\begin{array}{l}\text { nissioning } \\
\text { cility } \\
\text { cility }\end{array}$ & & & & & & \\
\hline
\end{tabular}

Other Assumptions Related to Facility Life Cycle:

- The 242-A Evaporator will operate through FY 2011; shutdown and terminal cleanout will occur in FY 2012 and FY 2013.

- The TWRS Privatization schedule is Phase I from June 2002 to May 2012, and Phase II from October 2011 to September 2029.

- The TWRS Phase II facilities include evaporation capability to replace the 242-A Evaporator.

- The ETF/LERF will receive waste until FY 2030; cleanout will occur in FY 2030 and FY 2032.

- The mission for the 200 Area TEDF will end in FY 2030; cleanout will occur in FY 2031.

- The 307 Retention Basins and the 300 Area TEDF will operate for as long as the process sewer and retention process sewer waste streams continue (estimated to be FY 2025).

- The 340 Waste Handling Facility will cease receipt of wastes at the end of FY 1998. Cleanout of the 340 Waste Handling Facility will be complete in FY 2001. 


\subsection{Project Safety Authorization Basis/NEPA and Permits.}

Requirements: The following safety documentation has been prepared for the Liquid Waste Program facilities.

- Operation and maintenance of the 242-A Evaporator are in accordance with WHC-SD-WM-SAR-023, 242-A Evaporator/Crystallizer Safety Analysis Report (Aguirre 1995).

- Operation and maintenance of the LERF are in accordance with HNF-SD-WMSAD-040, Liquid Effluent Retention Facility Final Hazard Category Determination (Chalk 1997), and HNF-SD-LEF-ASA-002, 242AL Liquid Effluent Retention Facility Auditable Safety Analysis (Galioto 1997).

- Operation and maintenance of the ETF are in accordance with WHC-SD-C018HHC-002, Hazard Categorization Report for the 200 Area Effluent Treatment Facility (Koerner 1995), and WHC-SD-ETF-ASA-001, 200 Area Effluent Treatment Facility Auditable Safety Analysis (Flyckt 1995).

- A preliminary safety evaluation was completed for the 200 Area TEDF ("Preliminary Safety Evaluation - 200 Area Treated Effluent Disposal Facility, Project W-049H"). The 200 Area TEDF is a general-use facility and safety documentation is not required according to DOE Order 5481.1B, Safety Analysis and Review System (DOE 1986). Operation and maintenance of the 200 Area TEDF shall be in accordance with the general safety requirements in WHC-CM-1-10, Safety Manual.

- Operation and maintenance of the 300 Area TEDF are in accordance with WHC-SD-WM-SAD-025, Hanford 300 Area Treated Effluent Disposal Facility Inventory at Risk Calculations and Safety Analysis (Olander 1995).

- Operation and maintenance of the 340 Waste Handling Facility are in accordance with WHC-SD-WM-ISB-003, 340 Waste Handling Facility Interim Safety Basis (ISB) (Stordeur 1997), and WHC-SD-TP-SARP-015, Safety Analysis Report for Packaging (On-Site) Double-Shell Tank Car (Smyth 1996).

- Operation and maintenance of the 307 Retention Basis are in accordance with WHC-SD-WM-SAD-027, Hanford 300 Area Retention Process Sewer Inventory at Risk Calculations and Safety Analysis (Berneski 1995).

NEPA Documentation--The Liquid Waste Program activities are being implemented based on completed NEPA reviews including the following:

- DOE/EA-0383, Environmental Assessment - Hanford Environmental Compliance Project (DOE 1992d) 
- Categorical Exclusion for Low-Level Liquid Waste Treatment Facilities Upgrades, Hanford Site, Richland, Washington (Dunigan 1996)

- DOE/EA-0980, 300 Area Process Sewer Piping Upgrade and 300 Area Treated Effluent Disposal Facility Discharge to the City of Richland Sewer System, Hanford Site, Richland (DOE 1995d)

- DOE/EIS-0113, Final Environmental Impact Statement: Disposal of Hanford Defense High-Level, Transuranic, and Tank Wastes, Hanford Site, Richland, Washington (DOE 1987)

- 53 FR 12449, "Disposal of Hanford Defense High-Level, Transuranic, and Tank Wastes, Hanford Site, Richland, Washington; Record of Decision"

- TWRS EIS (DOE 1996a)

- TWRS EIS ROD (DOE 1997a)

- Memorandum to file for coverage of LERF under HDW-EIS

- ERDA-1538, Waste Management Operations, Hanford Reservation, Richland, Washington: Final Environmental Statement (ERDA 1975)

- Categorical exclusion for alterations to 325 Building and 340 Facility (DOE approved).

\section{Planning Assumptions:}

- None.

\subsection{Other Requirements and Planning Assumptions.}

\section{Area Liquid Effluent Facilities}

The 242-A Evaporator concentrates dilute liquid tank wastes by evaporation. The volume of tank wastes is reduced to eliminate the need to construct additional storage tanks. The LERF consists of three RCRA-compliant surface impoundments for temporarily storing process condensate from the 242-A Evaporator and other wastewater. The wastewater from the LERF is treated in the ETF to remove toxic metals, radionuclides, and ammonia, and to destroy organics. The ETF treatment process constitutes BAT and includes $\mathrm{pH}$ adjustment, filtration, ultraviolet light/peroxide destruction of organics, reverse osmosis, and ion exchange. The treated effluent has been delisted from RCRA and is discharged to a state-approved land disposal site under a WAC 173-216 discharge permit. A truck-unloading station enables liquid effluents to be received from other projects and transferred to either the LERF for storage or directly to the ETF for treatment. The 200 Area TEDF is a collection and disposal system for other liquid effluents that have already had BAT/AKART applied by the generators. These liquid effluents are routed to 
another state-approved land disposal site and discharged under a separate WAC 173-216 discharge permit.

\section{Requirements:}

- Discharge limits for the ETF are specified in the WAC 173-216 State Waste Discharge Permit No. ST 4500 (Ecology 1995a) and the Final Delisting in 60 FR 31115, and codified in 40 CFR 261, "Identification and Listing of Hazardous Waste," Appendix IX, Table 2. Constituents not identified in permits are subject to limits in WAC 173-200, "Water Quality Standards for Ground Waters of the State of Washington;" background concentrations measured in the groundwater at the ETF State-Approved Land Disposal Site and documented in WHC-SD-C018H-PLN-004, Groundwater Monitoring Plan for the Proposed State Approved Land Disposal Structure (Reidel 1993); and 4\% of the derived concentration guide values in DOE Order 5400.5, Radiation Protection of the Public and the Environment (DOE 1990a).

- Discharge limits for the 200 Area TEDF are specified in the WAC 173-216 State Waste Discharge Permit No. ST 4502 (Ecology 1995b). Constituents not identified in permits are subject to limits in WAC 173-200, "Water Quality Standards for Ground Waters of the State of Washington;" and $4 \%$ of the derived concentration guide values in DOE Order 5400.5, Radiation Protection of the Public and the Environment (DOE 1990a).

\section{Planning Assumptions:}

- None.

\section{Area Liquid Effuent Facilities}

Nonradioactive and nonhazardous wastewater in the 300 Area is received via the process sewer and treated in the 300 Area TEDF. Liquid effluents from other projects that meet acceptance criteria can also be received and treated in the 300 Area TEDF. The wastewater is treated to remove heavy metals and cyanide, and to destroy organics. The 300 Area TEDF treatment process constitutes BAT and includes $\mathrm{pH}$ adjustment, iron co-precipitation, filtration, ultraviolet light/peroxide, and ion exchange. The treated effluent is discharged to the Columbia River under a National Pollutant Discharge Elimination System (NPDES) permit. Potentially contaminated wastewater in the 300 Area is collected in the 307 Retention Basins, monitored for radioactive contamination, and transferred to the 300 Area TEDF. Radioactive and mixed liquid waste in the 300 Area is collected at the 340 Waste Handling Facility and transferred by rail car to DSTs in the 200 East Area.

\section{Requirements:}

- Discharge limits for the 300 Area TEDF are specified in NPDES Permit No. WA-002591-7 and the Washington Department of Natural Resources Land Lease. 
Constituents not identified in permits are subject to limits in WAC 173-201A, "Water Quality Standards for Surface Waters of the State of Washington;" and 4\% of the derived concentration guide values in DOE Order 5400.5, Radiation Protection of the Public and the Environment (DOE 1990a).

- Waste acceptance criteria and information requirements for liquid waste transferred to tank farms from the 340 Waste Handling Facility are specified in WHC-SD-WMEV-053, Double-Shell Tank System Waste Analysis Plan (Mulkey 1996).

\section{Planning Assumptions:}

- None.

\section{Miscellaneous Streams}

Miscellaneous streams are a special category of industrial wastewater that discharges to the soil column. The Plan and Schedule for Disposition and Regulatory Compliance for Miscellaneous Streams, DOE/RL-93-94 (RL 1995c), provides a decision matrix to determine the permit requirements and methods of disposing of miscellaneous streams.

\section{Requirements:}

- Commitments established in the plan and schedule include registration of injection wells, submittal of applications for categorical discharge permits, annual update of the miscellaneous streams inventory, and implementation of best management practices.

\section{Planning Assumptions:}

- None.

4.2.2.2.7 Interfaces. The following table shows the projects that interface with the Liquid Waste Program, their project identification number (at the PBS level), and the relationship to the Liquid Waste Program.

\begin{tabular}{|l|l|l|}
\hline \multicolumn{1}{|c|}{ Project name } & \multicolumn{1}{|c|}{ Project number } & \multicolumn{1}{c|}{ Interface } \\
\hline $\begin{array}{l}\text { Tank Waste Remediation } \\
\text { System }\end{array}$ & $\begin{array}{l}\text { RL-TW03, RL-TW04, } \\
\text { RL-TW06, RL-TW07 }\end{array}$ & $\begin{array}{l}\text { Liquid effluents for treatment, feed to evaporator, } \\
\text { radioactive liquid waste from 300 Area }\end{array}$ \\
\hline Spent Nuclear Fuel & RL-WM01 & Liquid effluents for treatment \\
\hline Waste Management & $\begin{array}{l}\text { RL-WM03, RL-WM06, } \\
\text { RL-WM04 }\end{array}$ & $\begin{array}{l}\text { Liquid effluents for treatment, solid waste for } \\
\text { disposal, samples for analysis }\end{array}$ \\
\hline Facility Stabilization & $\begin{array}{l}\text { RL-TP01, RL-TP02, RL-TP04, } \\
\text { RL-TP05, RL-TP06, RL-TP08, } \\
\text { RL-TP09, RL-TP10, RL-TP14, } \\
\text { RL-TP11 }\end{array}$ & $\begin{array}{l}\text { Liquid effluents for treatment, contaminated } \\
\text { shutdown facilities }\end{array}$ \\
\hline
\end{tabular}


DOE/RL-97-55

Revision 0

January 30, 1998

\begin{tabular}{|l|l|l|}
\hline \multicolumn{1}{|c|}{ Project name } & \multicolumn{1}{|c|}{ Project number } & \multicolumn{1}{c|}{ Interface } \\
\hline Infrastructure & RL-TP13 & $\begin{array}{l}\text { Liquid effluents for treatment, clean shutdown } \\
\text { facilities }\end{array}$ \\
\hline Environmental Restoration & $\begin{array}{l}\text { RL-ER04, RL-ER06, RL-ER08, } \\
\text { RL-ER09, RL-ER05 }\end{array}$ & Liquid effluents for treatment \\
\hline Technology Management & RL-ST01 & $\begin{array}{l}\text { Liquid effluents for treatment, replacement for } \\
\text { 340 Facility }\end{array}$ \\
\hline
\end{tabular}

The Waste Management Program will provide solid waste, liquid waste, and analytical laboratory support as defined in the most recent approved revision of the solid waste, liquid waste, and Analytical Laboratory Services forecasts.

4.2.2.2.8 Logic Diagram. Figure 4-4 shows the flow of liquid effluents in the 200 and 300 Areas.

\subsection{Requirements References.}

- DOE/RL-96-92, Hanford Strategic Plan (RL 1996c)

- Tri-Party Agreement, Hanford Federal Facility Agreement and Consent Order (Ecology et. al 1996)

- Consent Order DE91NM-177 (Ecology and DOE 1991)

- WAC 173-216 State Waste Discharge Permit No. ST 4500 (Ecology 1995a) for the ETF

- 60 FR 31115, "Hazardous Waste Management System: Identification and Listing of Hazardous Wastes: Final Exclusion"

- DOE/RL-92-72, Federal Register Notice of U.S. EPA Approval of the 200 Area Effluent Treatment Facility Delisting Petition (Ballantyne 1993)

- DOE/RL-97-03, Hanford Facility Dangerous Waste Permit for LERF/ETF (RL 1997b)

- WAC 173-216 State Waste Discharge Permit No. ST 4502 (Ecology 1995b) for the 200 Area TEDF

- WA-002591-7, National Pollutant Discharge Elimination System Permit for the 300 Area TEDF

- Washington Department of Natural Resources Land Lease for the 300 Area TEDF 
DOE/RL-97-55

Revision 0

January 30, 1998

Figure 4-4. Logic Diagram for the Liquid Waste Program.
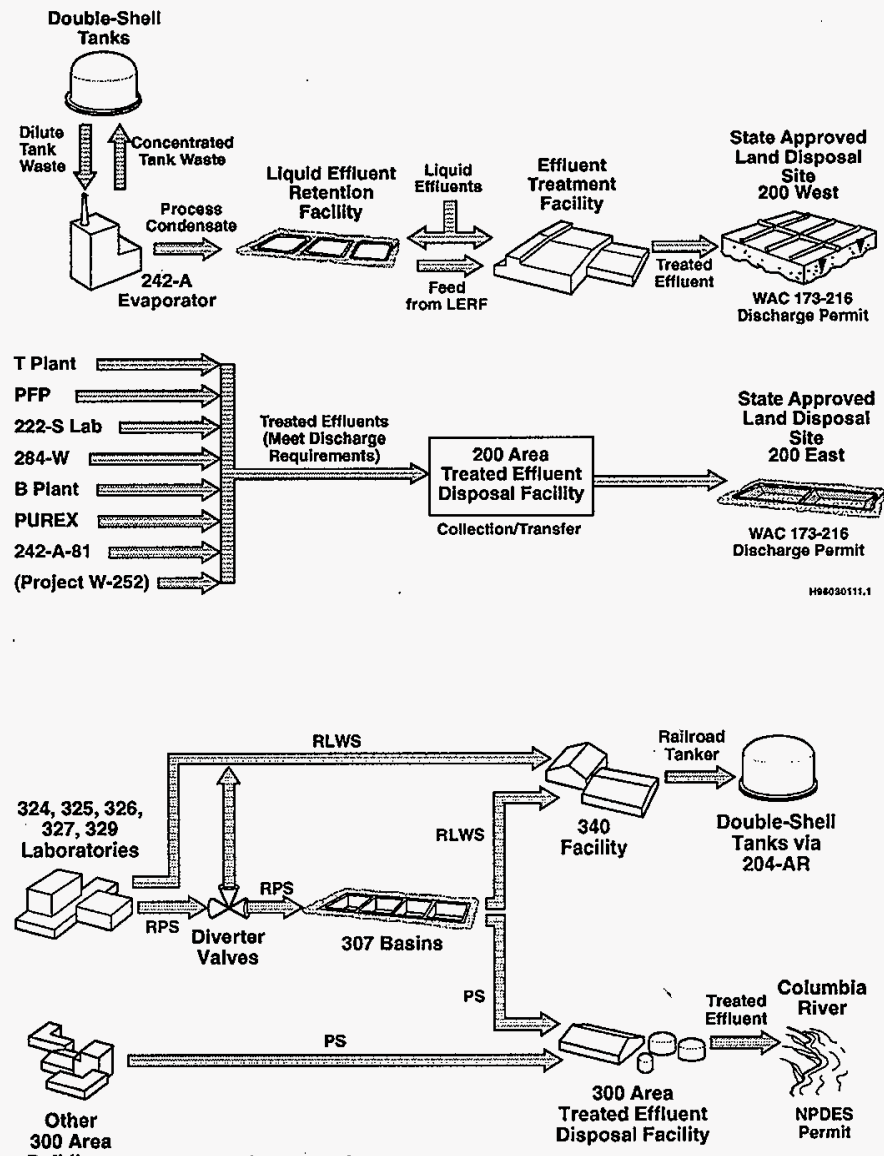

300 Area

$\mathrm{PS}=$ Process Sewer

RPS = Retention Process Sower

RLWS $=$ Radioactive LIquid Wasto System

He8030111.2 
- DOE/RL-93-94, Plan and Schedule for Disposition and Regulatory Compliance for Miscellaneous Streams (RL 1995c)

- Memorandum of Understanding--Disposition and Transport of Excess Water from $100-\mathrm{K}$ Basins to the 200 Area ETF

- Memorandum of Understanding--Storage and Treatment of Water from N Reactor Fuel Storage Basin and 1300-N Emergency Dump Basin

- Memorandum of Understanding--Treatment of Groundwater from 200-UP-1 Operable Unit at the 200 Area ETF

- Memorandum of Understanding for Use of the Radioactive Liquid Waste Sewer System

- Memorandum of Understanding for Storage and Treatment of ERDF Leachate at the LERF/ETF Complex.

\subsection{Planning Assumptions.}

- The Liquid Effluent Facilities will be fully utilized in cleaning up the Hanford Site.

- Modifications will be completed to the 325 Building and 204-AR Unloading Station to allow the 340 Waste Handling Facility to cease waste receipts at the end of FY 1998 as planned.

- Contaminated excess facilities are transferred to Facility Stabilization for deactivation. Clean excess facilities are transferred to the Landlord Project for re-use or demolition.

\subsubsection{Analytical Services.}

4.2.2.3.1 Project Description Summary. The Hanford Analytical Services Program (HASP) supports the Hanford Site mission by providing analytical services to Site programs. These services include waste and environmental sample analysis, process control support, field and sampling services, development services, and Site expertise in chemistry and data quality. The HASP operates onsite analytical laboratories, contracts commercial services, establishes Site laboratory quality standards, and integrates all Site analytical services. Cost-effective, quality, and timely services are provided using a combination of government-contracted and commercial capabilities based on biannual Site projections.

The 222-S Laboratory Facility Operations will operate as the Hanford Site high-level analytical laboratory for samples $>1 \mathrm{mR} / \mathrm{h}$. This program ensures that the 222-S Laboratory Complex is available in a ready-to-serve configuration. This includes maintenance of the building and analytical equipment, engineering, environmental and safety compliance, quality assurance, life-cycle replacement of obsolete analytical equipment, and facility upgrades. 
The Waste Sampling and Characterization Facility (WSCF) Complex will operate as the low-level analytical laboratory to provide analytical chemistry for samples $<10 \mathrm{mR} / \mathrm{h}$ in support of the Hanford Site programmatic mission. This activity ensures that the WSCF Complex is available in a ready-to-serve configuration. This includes maintenance of the building and analytical equipment, engineering, quality assurance, environmental and safety compliance, and facility upgrades.

\subsection{Geographic Requirements/Assumptions.}

\section{Requirements:}

- The HASP is a service organization and has no specific interim or final end point targets assigned to it in the Hanford Strategic Plan (RL 1996c).

\section{Planning Assumptions:}

- The HASP supports numerous end point targets assigned to other programs. The cleanup goals for each geographical area, and the end point targets assigned to other programs and supported by the HASP, are as follows.

\section{Reactors on the River}

Cleanup Goal: Remove and/or stabilize SNF, surplus facilities, and waste sites to protect groundwater and the Columbia River and to ensure protection of people, the environment, and natural/cultural resources. Pending Congressional action on the Wild and Scenic River designation, use will continue to be restricted; sensitive ecological, cultural, and Native American resources will be protected.

- Remove SNF and clean the K Basins sufficient to transition to D\&D.

- Drain, decontaminate, and stabilize the K Basins Facility.

\section{Central Plateau}

Cleanup Goal: The 200 Areas and Central Plateau will be used for the management of NM, the collection and disposal of waste materials that remain onsite, and for other related and compatible uses. Cleanup levels and disposal standards will be established that are consistent with these long-term uses.

- Continue to restrict groundwater use for a yet to be determined period; intercept or contain groundwater to within designated boundaries.

- Operate the ERDF to accept waste from remediation of CERCLA units across the Hanford Site.

- Continue to provide disposal in the 200 Area for LLW and MLLW (solids) from onsite and offsite sources. 
- Retrieve tank wastes to the extent needed for tank closure, divide into high-level and low-activity fractions, and immobilize.

- Continue treatment and disposal of liquid effluents through operations of the 242-A Evaporator, the LERF, the 200 Area ETF, and the 200 Area TEDF.

- Continue to provide safe storage for $\mathrm{Cs} / \mathrm{Sr}$ capsules in WESF indefinitely. The WESF is a decoupled and a standalone facility.

- Transition the PUREX Facility and B Plant to a low-cost, stable, deactivated condition.

- Complete stabilization of Pu in the PFP (DNFSB 94-1 implementation).

- Transition production areas of the PFP to a low-cost, stable, deactivated condition; continue safe, stable, interim storage of $\mathrm{Pu}$.

\section{South 600 Area}

Cleanup Goal: The 300 Area waste sites, materials, and facilities will be remediated to allow industrial and economic diversification opportunities. The federal government will retain ownership of land in and adjacent to the 300 and 400 Areas, but will lease land for private and public uses to support regional industrial and economic development. Excess land within the 1100 Area will be targeted for transition to non-federal ownership.

- Transition high-cost surplus facilities to a low-cost, stable, deactivated condition.

- Transition the 324 and 327 Buildings to a low-cost, stable, deactivated condition and disposition their NM (including 324 Building radioactive tank wastes).

- Continue treatment and disposal of liquid effluents through operations of the 300 Area TEDF and the 340 Waste Handling Facility.

\subsection{Material and Waste Flow Requirements/Assumptions.}

\section{Requirements:}

- None.

\section{Planning Assumptions:}

- Analytical Services forecasts the needs for services twice per year and these forecasts form the basis for the program. The forecasts are documented in WHC-SD-WMTI-608, Hanford Analytical Sample Projections 1996-2001 (Joyce 1996). Service types include hazardous waste, industrial waste, MLLW, and treated effluent.

Estimates are provided of the volumes received, generated, transferred, treated, and 
disposed. Life-cycle support needs for all programs of the Hanford Site cleanup mission are established in the Integrated Site Baseline and the Program Master Baseline Schedule.

\subsection{Facility Life-Cycle Requirements/Assumptions.}

\section{Requirements:}

- None.

Planning Assumptions: The following table identifies life-cycle responsibility for the major HASP facilities. The life-cycle phases correspond to those in DOE Order 430.1, Life-Cycle Asset Management (DOE 1995c). All the HASP facilities are currently operating and no new facilities are planned to be constructed.

\begin{tabular}{|l|c|c|c|c|c|c|c|c|c|}
\hline \multicolumn{1}{|c|}{ Asset } & $\begin{array}{c}\text { Program } \\
\text { planning }\end{array}$ & $\begin{array}{c}\text { Pre- } \\
\text { conceptual }\end{array}$ & Conceptual & Design & Const. & Turnover & O\&M & $\begin{array}{c}\text { Post- } \\
\text { operations }\end{array}$ & D\&D \\
\hline $\begin{array}{l}222-S \\
\text { Laboratory }\end{array}$ & -- & -- & -- & $\cdots$ & -- & $\cdots$ & RL-WM06 & RL-TP13 & RL-ER06 \\
\hline WSCF & -- & -- & -- & -- & $\cdots$ & -- & RL-WM06 & RL-WM06 & RL-ER06 \\
\hline
\end{tabular}

$D \& D=$ decontamination and decommissioning

O\&M = operations and maintenance

WSCF $=$ Waste Sampling and Characterization Facility

Other Assumptions Related to Facility Life Cycle:

- The 222-S Laboratory will operate through FY 2034, be deactivated, and transitioned to the ER Program.

- WSCF will operate through FY 2046 and then transitioned to the ER Program.

- Upgrades to extend the life of the 222-S Laboratory are planned from FY 2014 to FY 2015.

- Upgrades to extend the life of WSCF are planned from FY 2024 to FY 2025.

\subsection{Project Safety Authorization Basis/NEPA and Permits.}

\section{Requirements:}

- The results of the hazards analysis are reported in WHC-SD-CP-ISB-002, 222-S Laboratory Interim Safety Basis (Weaver 1996). Based on the results of this analysis and in accordance with DOE requirements and guidelines (DOE-STD1027-92 [DOE 1992e]), the 222-S Laboratory is categorized as a Category 3 nonreactor nuclear facility. This categorization implies that operation of the facility presents no unacceptable risk to onsite individuals, the public, or the environment. 
Protection of facility workers is accomplished through company and facility-specific control programs.

- The Final Safety Analysis Report for the Waste Sampling and Characterization Facility (McCullough 1994) categorized WSCF as a low-hazard nuclear facility. This FSAR demonstrates that the operation of WSCF is safe and presents no unacceptable risk to workers, Site personnel, or offsite personnel. After the FSAR, a safety assessment document (Meloy 1996) was completed in which it was concluded that WSCF was more accurately categorized as a non-nuclear, radiological facility.

\section{Planning Assumptions:}

- None.

\subsection{Other Requirements and Planning Assumptions.}

\section{Requirements:}

- Laboratory operations are required to comply with DOE/RL-96-68, Hanford Analytical Services Quality Requirements Document (HASQARD) (Hyatt 1996). The HASQARD includes all applicable DOE regulations as well as U.S. Environmental Protection Agency (EPA) requirements for laboratory support to RCRA, CERCLA, and other environmental regulations.

\section{Planning Assumptions:}

- None.

4.2.2.3.7 Interfaces. The HASP interfaces with the following projects:

- TWRS Project--Samples are received from the Tank Waste Storage Project and Tank Waste Disposal Project for analysis. Samples include high-activity tank samples, and analysis of solid and gaseous effluents supporting continued tank farm operations and waste characterization activities. Future support will be provided to tank waste retrieval, treatment, and disposal activities. High-level liquid wastes are transferred to TWRS from the 222-S Laboratory.

- SNF Project--Samples are received for analysis to support continued storage of SNF and the future removal and transport to the CSB.

- Waste Management Project--Samples are received from the Solid Waste and Liquid Waste Programs for analysis in support of continued storage, treatment, and operations. The 222-S Laboratory and WSCF generate solid and liquid effluents which are routed to the Solid Waste and Liquid Waste Programs. 
- FSP--Samples are received from Transition Projects facilities to support continued surveillance operations and to support facility deactivation and D\&D.

- Infrastructure Project--Samples are received from Infrastructure Operations and Maintenance for analysis in support of continued infrastructure operations.

- ER Project--Samples are received from Groundwater Management and the N Area for analysis. Future work will include support to excess facility deactivation and D\&D as well as remediation and closure of contaminated sites.

- Technology Management Project--Samples are received from Pacific Northwest Waste Management for analysis in support of technology development activities.

The Waste Management Program will provide solid waste, liquid waste, and analytical laboratory support as defined in the most recent approved revision of the solid waste, liquid waste, and Analytical Laboratory Services forecasts.

4.2.2.3.8 Logic Diagram. Samples flow to the appropriate laboratories (222-S, WSCF, or to commercial facilities), data are returned to the program customers, and excess sample material is archived or disposed of as applicable. Data management activities occur in HASP and with the customers.

\subsection{Requirements References.}

- DOE/RL-96-92, Hanford Strategic Plan (RL 1996c)

- Hanford Federal Facility Agreement and Consent Order (Ecology et al. 1996).

\subsection{Planning Assumptions.}

- The 222-S Laboratory and WSCF will continue to operate until FY 2034 and FY 2046 in support of the Hanford Site cleanup mission. Commercial contracts will continue to be used through FY 2046 as well.

- Upgrades are planned for the 222-S Laboratory and WSCF to extend the life of these facilities to support completion of the cleanup mission. Replacement laboratories are not planned at this time. Earlier shutdown of these facilities may be possible depending on the needs of the ER Project, Liquid Waste, Solid Waste, and TWRS.

- Laboratory support for the storage of SNM at the PFP will be provided by a dedicated facility located near the PFP 2736-ZB vaults. 
DOE/RL-97-55

Revision 0

March 30, 1998

\section{Spent Nuclear Fuel Project}

Concurrence: Original signed by E, D. Sellers on March 17. 1998 E. D. Sellers, Director Spent Nuclear Fuels Project Division, U.S. Department of Energy, Richland Operations Office
Approved by: Original signed by

C. A. Hansen on Mar. 30, 1998

C. A. Hansen, Office of Assistant Manager for Waste Management, U.S. Department of Energy, Richland Operations Office 


\subsubsection{SNF Project}

4.2.3.1 Project Description Summary. The SNF Project was formed to specifically address the urgent need to move metallic SNF from the present degraded storage conditions in the $105 \mathrm{~K}$ East and $105 \mathrm{~K}$ West Basins in the $100 \mathrm{~K}$ Area along the banks of the Columbia River to safe interim storage in the 200 Area on the Central Plateau. About $80 \%$ of the DOE's SNF inventory (approximately 2,100 MT) is located at the Hanford Site's K Basins. Fuel stored in the basins exists in a degraded state and further corrosion is continuing.

The SNF Project shall decrease human and environmental risk by removing SNF from the present deficient storage conditions and emplacing it into safe, cost-effective interim storage until a federal repository is available (approximately 40 years). The SNF Project shall also remove sludge and debris from the basins and treat water in the basins as needed to maintain water quality and reduce tritium levels.

Additionally, approximately $30 \mathrm{MT}$ of sitewide $\mathrm{SNF}$ are stored at various locations on the Hanford Site. The SNF Project shall consolidate this fuel in the 200 Area for safe interim storage or package it for shipment offsite for disposition.

\subsubsection{Geographic Requirements/Assumptions.}

\section{Requirements:}

- Spent Nuclear Fuel Project activities shall support the geographic area goals established by the Hanford Strategic Plan (RL 1996c) and the HRA-EIS and Comprehensive Land Use Plan (DOE 1986). Pending completion of the HRA-EIS and final geographic area requirements, the SNF Project shall be managed in accordance with the following geographic area planning assumptions.

\section{Planning Assumptions:}

- Spent Nuclear Fuel Project activities occur in the Reactors on the River, Central Plateau, and South 600 Area geographic areas. Relevant portions of the geographic area goals from the Hanford Strategic Plan (RL 1996c) are as follows.

\section{Reactors on the River}

Remove and/or stabilize SNF to protect groundwater and the Columbia River and to ensure protection of people, the environment, and natural and cultural resources.

\section{Central Plateau}

The 200 Areas and Central Plateau will be used for the management of NM, the collection and disposal of waste materials that remain onsite, and for other related and compatible uses. 


\section{South 600 Area}

The 300 Area materials will be remediated to allow industrial and economic diversification opportunities.

\subsubsection{Material and Waste Flow Requirements/Assumptions.}

\section{Requirements:}

- The SNF Project shall support achievement of interim and final end point targets identified in the Hanford Strategic Plan (RL 1996c) for the SNF material category. The targets are as follows.

\section{Reactors on the River}

- Spent fuel removed and $\mathrm{K}$ Basins cleaned sufficient to transition (for deactivation) (final end point target).

\section{Central Plateau}

- Spent fuels consolidated in the 200 Area in safe, stable, cost-effective interim storage pending national decisions on their ultimate disposition (interim end point target)

- Spent fuels removed offsite for final disposition (final end point target).

\section{South 600 Area}

- Spent fuels (light-water reactor) removed to interim storage in 400 Area pending availability of 200 Area interim storage (interim end point target)

- Spent fuels (Training Reactor, Isotopics, General Atomics [TRIGA*] and light-water reactor) and applicable Fast Flux Text Facility (FFTF) fuels removed from 400 Area interim storage to 200 Area (final end point target)

- Spent fuels (sodium [Na]-bonded Experimental Breeder Reactor-II test assemblies) removed offsite for final disposition (final end point target).

To achieve these targets, the SNF Project shall remove K Basins SNF from its current location, condition it for safe transport and storage, and place it into interim storage. The CSB and multi-canister overpacks (MCO) containing the SNF shall be capable of maintaining safe interim storage for a minimum of 40 years pending disposition in a national repository.

"TRIGA is a trademark of Gulf General Atomics Company, Inc. 
The SNF Project shall also consolidate sitewide SNF in the 200 Area Interim Storage Area (ISA). The project shall transload Na-bonded FFTF SNF and prepare it for shipment to the Idaho National Environmental and Engineering Laboratory (INEEL) for treatment and final disposition.

Spent nuclear fuel requiring added safeguards protection shall be consolidated in the PFP for interim storage. Spent nuclear fuel currently located in the 200 West Area Low-Level Burial Grounds will be transferred to the 200 Area ISA upon removal from the burial grounds.

The SNF Project shall retrieve sludge $\left(50\right.$ to $70 \mathrm{~m}^{3}$ ) from the K Basins. Sludge shall be considered SNF until it has been removed from the $\mathrm{K}$ Basins. Sludge that is removed from the $\mathrm{K}$ Basins by a sludge retrieval process shall be handled as mixed waste after removal from the basins.

The SNF Project will transfer secondary waste streams generated by project activities (such as solid LLW, TRU solid waste, and liquid effluents) for storage or disposal on the Hanford Site.

\section{Planning Assumptions:}

- Removal of SNF and sludge from the K Basins will be completed; K Basins sludge will be treated and then transferred to the TWRS for disposition with other DST wastes.

Water removed from the $\mathrm{K}$ Basins to maintain level control and during tritium reduction activities will be transferred to the 200 Area Effluent Treatment Facility (ETF) for disposition. Sitewide SNF currently located in 400 Area facilities will be consolidated at the 400 Area ISA pending availability of the 200 Area ISA. Hanford Site SNF will be shipped to the national repository without requiring additional treatment.

\subsubsection{Facility Life-Cycle Requirements/Assumptions.}

Requirements: The following table identifies life-cycle responsibility for major SNF Project facilities. The Hanford Site Technical Baseline Database uses these data to define interfaces between Hanford Site projects. The life-cycle phases are those identified in DOE Order 430.1, Life-Cycle Asset Management (DOE 1995c).

\begin{tabular}{|c|c|c|c|c|c|c|c|c|c|}
\hline \multirow{3}{*}{ Major facility } & \multicolumn{9}{|c|}{ Life cycle } \\
\hline & \multirow{2}{*}{$\begin{array}{l}\text { Program } \\
\text { planning }\end{array}$} & \multirow{2}{*}{$\begin{array}{c}\text { Pre- } \\
\text { conceptual }\end{array}$} & \multirow[b]{2}{*}{ Conceptual } & \multicolumn{3}{|c|}{ Execute } & \multirow{2}{*}{$\begin{array}{l}\text { Operations \& } \\
\text { maintenance }\end{array}$} & \multicolumn{2}{|c|}{ Close out } \\
\hline & & & & Design & Construction & Turnover & & $\begin{array}{c}\text { Post- } \\
\text { operations }\end{array}$ & $D \& D$ \\
\hline $\begin{array}{l}100 \mathrm{~K} \text { Area } \\
\text { Facilitics }\end{array}$ & $\begin{array}{l}\text { RL-WM01 } \\
\text { RL-TP09 }\end{array}$ & $-\cdot$ & $\cdots$ & $\cdots$ & $-\cdot$ & $\cdots$ & RL-WM01 & $\begin{array}{l}\text { RL-TP09 } \\
\text { RL-ER05 }\end{array}$ & $\mid \begin{array}{l}\text { RL-ER06 } \\
\text { RL-ER07 }\end{array}$ \\
\hline $\begin{array}{l}\text { Canister Storage } \\
\text { Building }\end{array}$ & RL-WMOL & RL-WM01 & RL-WM01 & RL-WMOl & RL-WM01 & RL-WM01 & $\begin{array}{l}\text { RL-WM01 } \\
\text { RL-WM02 }\end{array}$ & RL-WM02 & RL-WM02 \\
\hline
\end{tabular}




\begin{tabular}{|c|c|c|c|c|c|c|c|c|c|}
\hline \multirow{3}{*}{ Major facility } & \multicolumn{9}{|c|}{ Life cycle } \\
\hline & \multirow{2}{*}{$\begin{array}{l}\text { Program } \\
\text { planning }\end{array}$} & \multirow{2}{*}{$\begin{array}{c}\text { Pre- } \\
\text { conceptual }\end{array}$} & \multirow[b]{2}{*}{ Conceptual } & \multicolumn{3}{|c|}{ Execute } & \multirow{2}{*}{$\begin{array}{l}\text { Operations \& } \\
\text { maintenance }\end{array}$} & \multicolumn{2}{|c|}{ Close out } \\
\hline & & & & Design & Construction & Turnover & & $\begin{array}{c}\text { Post- } \\
\text { operations }\end{array}$ & D\&D \\
\hline $\begin{array}{l}200 \text { Area } \\
\text { Interim Storage } \\
\text { Area }\end{array}$ & RL-WMOI & RL_WM01 & RL-WM01 & RL-WM01 & RL-WM01 & RL-WM01 & $\begin{array}{l}\text { RL-WM01 } \\
\text { RL-WM02 }\end{array}$ & $\mathrm{RL}-\mathrm{WMO} 2$ & RL-WM02 \\
\hline
\end{tabular}

$\mathrm{D} \& \mathrm{D}=$ decontamination and decommissioning

\section{Planning Assumptions:}

- The SNF Project will be followed by deactivation of the $\mathrm{K}$ Basins and surrounding facilities as part of Facilities Transition Projects. This includes removal of basin water, D\&D of the $100 \mathrm{~K}$ Area as part of the ER Project, and SNF interim storage and final disposition operations as part of the CSB Operations Project. The $100 \mathrm{~K}$ Area facilities for which the SNF Project has responsibility are identified in BHI-00888, Memorandum of Understanding Between Westinghouse Hanford Company and Bechtel Hanford, Inc. (Dunkirk 1996).

4.2.3.5 Key Technical Requirements. The SNF Project was established to remove the fuel from existing canisters and repackage it for cold vacuum drying (CVD) to remove bulk water from the fuel. The SNF shall be transferred to the CSB for staging before hot conditioning to enable interim storage in the CSB. The primary technical requirements for the major facilities noted in Section 4.2.3.4 are as follows.

4.2.3.5.1 $100 \mathrm{~K}$ Area Facilities. The scope of the $100 \mathrm{~K}$ Area facilities includes the $\mathrm{K}$ Basins, CVD Facility, the MCO, cask/transportation system, and ancillary support facilities. The SNF Project shall perform the following activities.

- Maintain safe operation in the $\mathrm{K}$ Basins in accordance with the authorized safety basis and in compliance with approved S/RIDs.

- Remove and repackage K Basins SNF into MCOs suitable for downstream fuel handling and interim storage.

- Dry the K Basins SNF in the CVD Facility to remove free water to enable safe transport to CSB.

- Remove and treat sludge and debris from the $\mathrm{K}$ Basins for disposition with other Hanford Site wastes and materials.

- Treat water contained in the basins to maintain water quality and safe conditions within the basins and to reduce tritium levels. 
- Acquire and operate systems and facilities to achieve Tri-Party Agreement M-34-00 milestones for initiation and completion of fuel and sludge removal and tritium level reductions and in accordance with DNFSB Recommendation 94-1 implementation agreements (DNFSB 1994b) as documented in HNF-EP-0853, Hanford Site Integrated Stabilization Management Plan (McCormack 1997).

- Manage $\mathrm{K}$ Basins facilities and activities in accordance with the following:

- 97-SFD-149, Acceptance of K Basin Sludge Storage and Disposal Recommendation (Wagoner 1997)

- Memorandum of Understanding (Between WHC-SNF Project, WHC-TWRS, DOE-AMW and DOE-TWRS), " $K$ Basins Sludge Transfer to Tank Waste Remediation System" (Fulton 1996)

- Memorandum of Understanding (Between SFD and WPD), "Disposition and Transport of Excess Water from 100-K Basins to the 200 Area Effluent Treatment Facility" (Sellers and Teynor 1996)

- 96-SFD-238, Memorandum of Understanding (Between SFD, TPD, and RPD), "Transition of Management Responsibility for the 100-K Basins Facilities" (Sellers 1996).

\section{Planning Assumptions:}

- A total of $400 \mathrm{MCO}$ will provide sufficient storage capacity for $\mathrm{K}$ Basins SNF; 5 casks/transporters will be adequate to support the negotiated fuel removal schedules.

- Four processing stations within the CVD Facility will provide sufficient throughput to meet negotiated fuel removal schedules.

- Water removed from the MCOs during CVD processing will be returned to the K Basins.

4.2.3.5.2 CSB. The scope of the CSB includes the facilities for MCO receiving and staging, the Hot Conditioning System (HCS), and interim storage capability. The requirements and planning assumptions are as follows.

\section{Requirements:}

- Maintain MCO receiving, staging, hot conditioning, monitoring, and interim storage capability within the authorized safety basis and in accordance with approved S/RMs.

- Stage MCOs upon receipt from the $100 \mathrm{~K}$ Area Facilities until hot conditioning is available. 
- Condition SNF to remove bound water and begin safe interim storage.

- Acquire and operate systems and facilities to achieve Tri-Party Agreement M-34-00 milestones for initiation and completion of hot conditioning and achievement of interim storage and in accordance with DNFSB Recommendation 94-1 implementation agreements as documented in HNF-EP-0853, Hanford Site Integrated Stabilization Management Plan (McCormack 1997).

\section{Planning Assumptions:}

- Canister Storage Building Vault 1 will be sufficient to accommodate K Basins SNF.

- Vaults 2 and 3 will be available for storage of IHLWs from the Hanford Site and support systems must accommodate both SNF and IHLW.

- The MCOs and CSB will be designed for an interim storage period of 40 years.

- The MCOs will be sealed during the staging and interim storage periods.

- Six processing stations within the HCS will provide sufficient capacity to meet negotiated interim storage commitments.

4.2.3.5.3 200 Area ISA. The 200 Area ISA shall be constructed next to the CSB and used for interim storage of sitewide SNF. The ISA shall use CSB systems for handling and transloading of SNF containers as necessary. The SNF Project shall perform the following activities.

- Maintain the 200 Area ISA within the authorized safety basis and in accordance with approved S/RWs.

- Load Na-bonded FFTF fuel into shipping casks for shipment to INEEL in accordance with schedules established by the national SNF Program.

- Manage sitewide SNF in accordance with the following DOE-approved Memoranda of Understanding (MOU).

- 96-STO-033, Memorandum of Understanding, Management of 300 Area Light-Water Reactor Spent Nuclear Fuel (DOE 1996b)

- 96-SFD-127, Memorandum of Understanding for Management of Neutron Radiography Facility Training Reactor, Isotopics, General Atomics Spent Nuclear Fuel (DOE 1996c)

- 97-SFD-197, Programmatic Agreement Between Fast Flux Test Facility Project and Spent Nuclear Facility Project (DOE 1997c) 
- 96-SFD-166, Memorandum of Understanding for Management of Spent Nuclear Fuel Currently Located at T Plant and the 200 Area Low-Level Burial Grounds (DOE 1996d)

- 96-SFD-171, Memorandum of Understanding for Management of Spent Nuclear Fuel Currently Located at the Plutonium Finishing Plant (DOE 1996e).

- Plan for disposition of miscellaneous reactor fuel assemblies stored at the PFP and in the 200 West Area Low-Level Burial Grounds.

\section{Planning Assumptions:}

- Sitewide SNF will be transferred from the 400 Area ISA to the 200 Area ISA.

- Shippingport PWR Core II assemblies stored at T Plant will be received at the 200 Area ISA for storage inside the CSB.

- Sodium-bonded FFTF fuel will be shipped to INEEL.

4.2.3.6 Project Safety Authorization Basis/NEPA and Permits. The SNF Project shall manage all activities in accordance with approved Authorization Basis documents and approved S/RIDs. The following Authorization Basis documents, their associated safety evaluation reports, and S/RIDs apply upon approval by the DOE.

- WHC-SD-SNF-RD-001, SNF K Basins Standards/Requirements Identification Document (Watson 1995), to be replaced by HNF-SD-SNF-RD-001, SNF K Basins/Cold Vacuum Drying Facility Standards/Requirements Identification Document upon approval by the $\mathrm{DOE}$

- FNF-SD-SNF-RD-007, SNF Canister Storage Building/Hot Conditioning System Standards/Requirements Identification Document (Sandoz 1997)

- WHC-SD-WM-SAR-062, K Basins Safety Analysis Report (Meichle 1996) supplemented by 96-SFD-264 (Wagoner 1996a)

- HNF-SD-SNF-RPT-004, Canister Storage Building (CSB) Safety Analysis Report Phase 3: Safety Analysis Documentation Supporting CSB Construction (Garvin 1997a) to be updated by the FSAR as construction is completed

- HNF-SD-SNF-SAR-002, Safety Analysis Report for the Cold Vacuum Drying Facility, Phase I, Supporting Civil/Structural Construction (Garvin 1997b) to be updated by revision to the $\mathrm{K}$ Basins safety analysis report as construction is completed

- HNF-SD-SNF-SARR-005, Multicanister Overpack Topical Report (Lorenz 1997) 
- HNF-SD-TP-SARP-017, Safety Analysis Report for Packaging (Onsite) MCO Cask (Edwards 1997).

The SNF Project activities are subject to NEPA and shall comply with the NEPA ROD and equivalent CERCLA requirements. The following NEPA documents apply to the SNF Project.

- DOE/EIS-0245F, Management of Spent Nuclear Fuel from the K Basins at the Hanford Site, Richland, Washington (Addendum Final Environmental Impact Statement) (DOE 1996f)

- DOE/EA-1030, Characterization of Stored Defense Production Spent Nuclear Fuel and Associated Materials at Hanford Site, Richland, Washington (DOE 1995e)

- DOE/EA-1185, Management of Hanford Site Non-Defense Production Reactor Spent Nuclear Fuel, Hanford Site, Richland, Washington (DOE 1997d).

\section{Planning Assumptions:}

- The SNF Project activities related to sludge and debris removal at the $\mathrm{K}$ Basins will be regulated under CERCLA following completion of the Engineering Evaluation/Cost Analysis for K Basins Removal Activities ROD.

\subsubsection{Other Requirements and Planning Assumptions.}

\section{Requirements:}

- The DOE regulatory policy on the U.S. Nuclear Regulatory Commission nuclear safety equivalency will be applied to SNF new facilities and activities associated with fuel removal from the K Basins (Sellers 1995).

- The SNF Project will comply with applicable environmental permits. Specific, applicable permits will be identified in the Authorization Agreement to be issued in May 1998.

\section{Planning Assumptions:}

- The RCRA does not apply to SNF. 


\subsubsection{Interfaces.}

\begin{tabular}{|l|c|l|}
\hline \multicolumn{1}{|c|}{ Project title } & Project number & \multicolumn{1}{|c|}{ Interface } \\
\hline Tank Farm Operations & RL-TW03 & $\begin{array}{l}\text { For disposition of LLW, TRU waste, and liquid effluents } \\
\text { and for disposition of sludge from the K Basins }\end{array}$ \\
\hline $\begin{array}{l}\text { Immobilized Waste Storage \& } \\
\text { Disposal }\end{array}$ & RL-TW09 & $\begin{array}{l}\text { For disposition of LLW, TRU waste, and liquid effluents; } \\
\text { for modification of Vaults 2 and 3 and storage of TWRS } \\
\text { IFHW and other wastes }\end{array}$ \\
\hline Solid Waste Storage \& Disposal & RL-WM03 & $\begin{array}{l}\text { For disposition of LLW, TRU waste, and liquid effluents } \\
\text { and for Shippingport PWR Core II fuel }\end{array}$ \\
\hline Liquid Waste & RL-WM05 & For disposition of LLW, TRU waste, and liquid effluents \\
\hline K Basin Deactivation & RL-TP09 & $\begin{array}{l}\text { For turnover of 100 K Area facilities for deactivation } \\
\text { following completion of Spent Nuclear Fuel Project } \\
\text { activities }\end{array}$ \\
\hline Advanced Reactors Transition & RL-TP11 & For FFTF fuel and 400 Area ISA operations \\
\hline 324/327 Facility Transition & RL-TP08 & For fuel stored in the 324 and 327 Buildings \\
\hline PFP Vault Management & RL-TP07 & For fuel to be stored at PFP \\
\hline $\begin{array}{l}\text { Idaho National Environmental and } \\
\text { Engineering Laboratory }\end{array}$ & -- & $\begin{array}{l}\text { For coordination of national spent nuclear fuel policy } \\
\text { issues }\end{array}$ \\
\hline
\end{tabular}

FFTF $=$ Fast Flux Test Facility
IHLW $=$ immobilized high-level waste
ISA $=$ Interim Storage Area
LLW $=$ low-level waste
PFP = Plutonium Finishing Plant
PWR $=$ Pressurized Water Reactor
TRU $=$ transuranic
TWRS = Tank Waste Remediation System

The Waste Management Program will provide solid waste, liquid waste, and analytical laboratory support as defined in the most recent approved revision of the solid waste, liquid waste, and Analytical Laboratory Services forecasts.

\subsubsection{Logic Diagram. Refer to Figure 4-5.}

\subsubsection{Other Requirements References.}

- The SNF Project will comply with the U.S. Nuclear Regulatory Commission equivalency requirements described in WHC-SD-SNF-DB-003, Spent Nuclear Fuel Project Path Fonward Additional NRC Requirements (Garvin 1996), as applied to new construction. 
Figure 4-5. Logic Diagram for the Spent Nuclear Fuel Project.

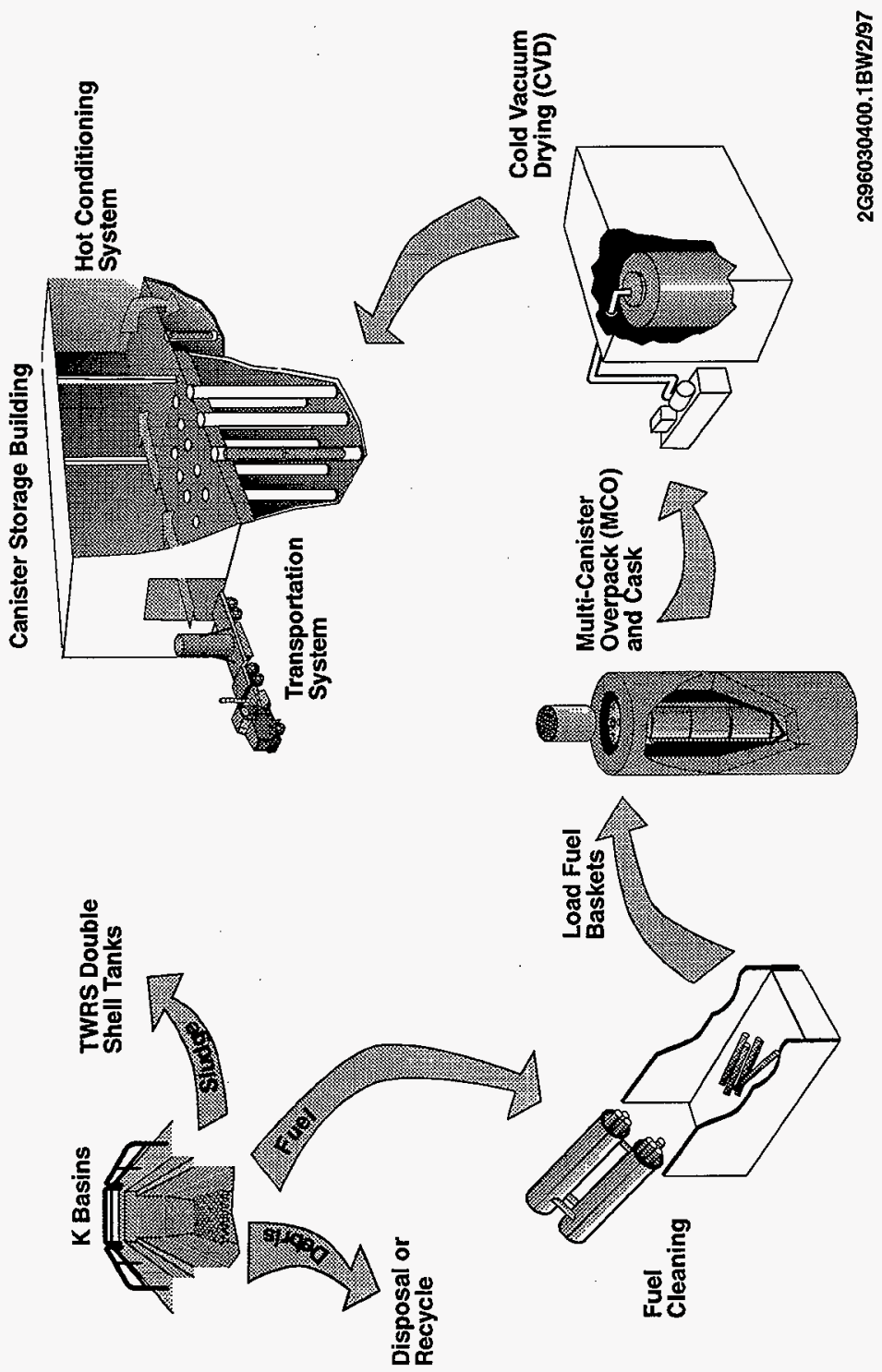


- The SNF Project will comply with DOE/RW-0333P, Quality Assurance Requirements and Description for the Civilian Radioactive Waste Management Program (DOE 1992f).

\subsubsection{Other Planning Assumptions.}

- K Basin Sludge Disposal--Regulatory and technical issues require resolution before a sludge disposal path can be confirmed. Major issues include discovery of TSCAregulated levels of PCBs in the sludge and compatibility with the existing DST safety basis. The current planning assumption is that the sludge will be treated before being dispositioned along with HLW at TWRS.

- SNF Disposal Location--The SNF Project will make a best-effort attempt to meet current acceptance criteria and will assume that no further treatment of the fuel will be required for the SNF to be disposed of in the geologic repository. 
DOE/RL-97-55

Revision 0

May 28, 1998

\section{Facility Stabilization Project}

Concurrence: Orig. signed by J E. Mecca J. E. Mecca, Division Director, Transition Programs Division, U.S. Department of Energy, Richland Operations Office
Approved by: Orig_signed by P. M. Knollmeyer

P. M. Knolimeyer, Assistant Manager, Office of Assistant Manager for Facility Transition, U.S. Department of Energy, Richland Operations Office 


\subsubsection{FSP Project}

The primary FSP mission is to deactivate facilities on the Hanford Site, in preparation for $D \& D$, and to provide safe and secure storage of SNM, NM, and nuclear fuel (NF) until these materials can be transferred to another facility, sold, or dispositioned.

The primary FSP objectives include the following.

- Develop detailed facility deactivation plans, end point criteria, and regulatory documentation.

- Achieve compliance with ES\&H codes and standards during deactivation and establish a passively safe and environmentally secure configuration that is easily maintained until final D\&D.

- Implement cost-effective, innovative approaches to ensure the required safety envelope is defined and maintained during deactivation.

- Apply lessons learned on other deactivation projects.

- Reduce the annual S\&M cost by a factor of ten after completion of deactivation.

- Complete deactivation and turnover of subprojects within approved baseline schedules.

- Protect the health and safety of the public, workers, and environment.

- Seek beneficial uses for facilities, equipment, and materials (all types) and resources.

- Consolidate SNM/NM/NF to the maximum extent practical.

- Maintain safe, secure, and compliant storage of SNM/NM/NF until final disposition of these materials can be accomplished.

- Conduct work in accordance with the Tri-Party Agreement; local, national, international, and other agreements; and in compliance with all applicable federal, state, and local laws.

- Involve stakeholders in the decision processes including establishing priorities, and in developing a consistent set of rules, regulations, and laws.

- Leverage work with a view of providing positive, lasting economic impact in the region. 
Section 14 of the Tri-Party Agreement describes the facility decommissioning process and divides it into three main phases. The three phases are transition, surveillance, and maintenance and disposition. The FSP is typically responsible for the transition phase when dealing with contaminated facilities.

The FSP shall use guidance contained in WHC-SD-CP-MAR-003, Mission Analysis Report: Deactivation Facilities at Hanford (Lund 1996), the Hanford Excess Facility Management Plan, and the U.S. Department of Energy, Office of Environmental Management, Office of Nuclear Material and Facility Stabilization Material Stabilization and Facility Deactivation Project Policies and Supplemental Information as a basis for planning and executing subprojects.

The management of SNM/NM/NF (including irradiated and nonirradiated) shall include the receiving, handling, processing, storing, and transfer for ultimate disposition of these materials in a safe, efficient, and environmentally responsible manner. Materials included are $\mathrm{Pu}$ (and highly enriched uranium [HEU]) as inventoried, SNF, $\mathrm{Cs} / \mathrm{Sr}$ capsules, thorium (Th), and miscellaneous actinides such as neptunium and californium, nuclear standards and sources, and $U$ (depleted, naturally occurring, and low-enriched).

\subsubsection{Project Description Summary.}

4.2.4.1.1 Project Overview. The FSP shall contain the following subprojects: B Plant, WESF, 300 Area/SNM, PFP Deactivation, PFP Stabilization, PFP Vault Management, 324/327 Facility Transition, Accelerated Deactivation, Advanced Reactors Transition (ART), the 300 Area Disposition Project, PUREX, and Transition Project Management.

Transition Project Management shall provide a centralized program, project, and business management to plan, execute, and control the FSP. Transition Project Management shall provide for common safeguards and security (SAS) support; centralized coordination of ES\&H, radiological control, and quality assurance; systems engineering; new technology development and implementation support; policies and procedure development; excess facility and material planning (includes development of special projects such as the 300 Area Disposition Project, Accelerated Deactivation Project, etc.); FSP strategic planning; procurement support; management of SNM; and operations integration support. Support for technical development of 200 Area Canyon Entombment and FDH project management direction is also provided.

The FSP shall support the planning assumptions contained in the Comprehensive Land Use Plan goals by performing the following activities.

a. Maintaining the safety, security, and compliance envelope involves maintaining safe, secure, and compliant facility operations; facility and equipment maintenance; maintenance of safety, safeguards, engineering, and other compliance documentation; maintenance of qualified facility personnel; and the performance of self-assessments. Maintaining all plants at minimum safe levels shall take precedence over other program functions. 
b. Developing facility deactivation plans for characterization of the initial facility state, performing deactivation planning, regulatory documentation preparation, long-term facility S\&M plan preparation, facility turnover end point document development, turnover package preparation, and design of the physical turnover states to guide facility and system reconfigurations. Applicable requirements set forth in draft DOE Order 58XXXXX, Transition of Facilities to the Office of Environmental Restoration and Waste Management, shall be used as guidance. The turnover package shall contain the necessary and sufficient physical facility status and control information necessary for EM-40 to perform long-term, low-cost S\&M and eventual safe D\&D of the facility.

c. The stabilizing and reconfiguring of facilities for minimum S\&M include deactivation of nonessential utilities, process systems, and other facility systems; modification of facility safety, ventilation, monitoring, electrical, and utility systems; removal of resources and waste; and transfer of the facility to the ERC. Remaining active systems shall be capable of operation and statusing from a location outside the facility so only quarterly personnel entry is required. Facility electrical systems shall be reconfigured so only minimal portions can be operated as required to support personnel entry. All facility reconfiguration shall be performed under Occupational Safety and Health Administration construction requirements.

d. Dispositioning facility inventories of SNM/NM/NF through the stabilization, treatment, packaging, temporary storage, documentation preparation, and transportation of these materials to another location.

e. Prioritizing facility transitions to minimize risk and maximize total return on investment.

f. Identifying and removing or stabilizing in place radioactive and hazardous materials. Materials shall be removed and/or stabilized sufficiently to ensure that the plant complies with WHC-CM-7-5, Environmental Compliance, and DOE/RL-96-109, Hanford Site Radiological Control Manual (RL 1997c), as applicable to an unoccupied facility after completion of deactivation. As a general guide, as-left contamination and radiation levels in plant areas shall be no more than the levels encountered during normal operation and occupancy of the plants.

g. Controlling imminent hazards to personnel or the environment through removal, isolation, mitigation, or stabilization. Structures shall be in a safe condition with immediate threats to human health and safety removed or appropriate compensatory measures implemented. Surplus materials and equipment shall be removed and other beneficial uses sought.

h. Employing a graded approach to characterization of the facility to focus on high-risk areas. Because long time periods may be expected between deactivation and final disposition, characterization of the facility shall be performed while knowledgeable facility staff members are available and records are fresh. 
i. Achieving compliance with ES\&H codes and standards during facility deactivation.

j. Involving stakeholders in the development of deactivation project plans.

k. Ensuring final facility configurations do not preclude D\&D activities.

1. Achieving a non-occupied facility status.

$m$. Performing evaluations and engineering studies using BAT/AKART for air and liquid effluents.

n. Conducting air emission inventories, updating facility effluent monitoring plans, assessing compliance with NESHAPs (40 CFR 61) monitoring requirements, and supporting preparation of annual Hanford Site air emissions reports.

o. Providing validated, technical baselines (cost and resource-loaded schedules) for the projects supporting the Hanford Site cleanup mission, from which project costs can be monitored and minimized while project milestones are properly managed to completion.

p. Providing cost-effective use of project work forces and resources to minimize the need for strategic redeployment or outplacement activities.

q. Managing SNM/NM/NF material as follows:

- Consolidating SNM/NM/NF materials early in the facility deactivation process to minimize the safety and compliance envelope. Where feasible, these materials shall be removed from the facility early in the deactivation process. When deactivation is complete, a facility shall no longer contain SNM/NM/NF.

- Safely and compliantly storing SNM/NM/NF until a national policy on disposition is formulated. The SNM/NM/NF shall be transferred to other beneficial uses where possible. All NM held by DOE contractors shall be stored, transferred, and dispositioned in compliance with DOE guidance and federal, state, and local laws.

- Continuing the current SNM/NM/NF SAS approach, with necessary interim upgrades, until a preferred longer term approach is selected.

- Continuing development and implementation of criteria for the receipt, storage, treatment, and disposition of SNM/NM/NF.

- Continuing studies to determine the best alternatives for onsite material storage and disposition.

- Actively involving stakeholders in the development of long-term treatment, storage, and disposition plans through the NEPA process. 
- Delaying SNM/NM/NF treatment for ultimate disposition until final disposition for these materials is determined.

4.2.4.1.2 Geographic Requirements/Assumptions. Refer to Section 2.3 for geographic requirements and assumptions.

\subsection{Material and Waste Flow Requirements/Assumptions.}

\section{Requirements:}

- Hazardous, radioactive LLW, MLLW, and TRU shall be packaged and shipped in accordance with WHC-EP-0063-4, Hanford Site Solid Waste Acceptance Criteria (Willis 1993).

\section{Planning Assumptions:}

- The FSP will identify SNM/NM/NF inventories and track them through transfer, receipt, storage, and disposition. The FSP will further develop schedules for transfer, receipt, storage, and disposition of the SNM/NM/NF as NEPA RODs and other disposition decisions are made.

- The FSP deactivation and stabilization actions will generate small amounts of tank waste that will be transferred to TWRS.

- The FSP deactivation and stabilization actions will generate LAW streams (such as solid LLW, TRU solid waste, and liquid effluents) that will be transferred to the appropriate Hanford Site contractor for disposition.

Refer to the FSP subprojects for a more detailed discussion of waste and material flows and requirements and assumptions.

\subsection{Facility Life-Cycle Requirements/Assumptions.}

\section{Requirements:}

- None.

\section{Planning Assumptions:}

- Life-cycle planning and budget responsibility for major FSP facilities are identified in the subprojects. The Hanford Site Technical Baseline Database uses these data to define interfaces between Hanford Site projects. The life-cycle phases are those identified in DOE Order 430.1, Life-Cycle Asset Management (DOE 1995c).

Deactivation of remaining contaminated excess facilities not already in the FSP or part of the ERC (excluding the T Plant Complex) are grouped into two outyear PBS's as follows: 
- 300 Area Disposition Project, which deals with the deactivation, conversion, and D\&D of 300 Area facilities not covered by other FSP/ERC PBS's

- Accelerated Deactivation Project, which deals with deactivation of excess contaminated facilities outside the 300 Area not included in other FSP PBS's.

4.2.4.1.5 Project Safety Authorization Basis. Generally speaking, each FSP subproject has its own Safety Authorization Basis and S/RID documentation. These documents will be referenced in the individual subproject sections. Each FSP subproject will have its own NEPA, RCRA, or CERCLA documentation. These documents will also be referenced in the individual subproject sections.

The FSP deactivation and material treatment, storage, and disposition activities shall be evaluated against approved safety basis documentation to identify any potential USQs. If the activity is covered by the analysis in the safety basis, no additional safety basis documentation or evaluation is required. If the activity is not covered, the work plans must be modified to stay within the bounds of the existing safety basis or the safety basis must be modified through additional safety analysis. Once $\mathrm{RL}$ approves the new analysis, it shall become part of the approved safety basis.

4.2.4.1.6 Other Requirements and Planning Assumptions. Key requirements and planning assumptions will be listed in individual subproject sections.

\subsection{Interfaces.}

\begin{tabular}{|l|c|l|}
\hline \multicolumn{1}{|c|}{ Project title } & Project number & \multicolumn{1}{|c|}{ Interface } \\
\hline Tank Farm Operations & RL-TW03 & For disposition of tank waste through 2005 \\
\hline $\begin{array}{l}\text { Science and Technology } \\
\text { Project }\end{array}$ & $\begin{array}{l}\text { RL-ST01 and } \\
\text { OT-03 }\end{array}$ & $\begin{array}{l}\text { To facilitate turnover of contaminated excess facilities for } \\
\text { deactivation to either new future uses or D\&D }\end{array}$ \\
\hline Landlord & RL-TP13 & $\begin{array}{l}\text { To facilitate turnover of contaminated excess facilities for } \\
\text { deactivation to either new future uses or D\&D and to supply } \\
\text { infrastructure support and accept sanitary waste and other landfill } \\
\text { waste materials }\end{array}$ \\
\hline $\begin{array}{l}\text { Solid Waste Storage \& } \\
\text { Disposal }\end{array}$ & RL-WM03 & $\begin{array}{l}\text { For disposition of low-level waste and transuranic waste and to } \\
\text { facilitate tumover of contaminated excess facilities for deactivation } \\
\text { to either new future uses or D\&D }\end{array}$ \\
\hline Liquid Waste Program & RL-WM05 & $\begin{array}{l}\text { For disposition of liquid effluents and to facilitate turnover of } \\
\text { contaminated excess facilities for deactivation to either new future } \\
\text { uses or D\&D }\end{array}$ \\
\hline Retrieval & RL-TW04 & For disposition of tank waste after 2005 \\
\hline Analytical Services & RL-WM06 & $\begin{array}{l}\text { For sample analysis and other laboratory support and to facilitate } \\
\text { turnover of contaminated excess facilities for deactivation to either } \\
\text { new future uses or D\&D }\end{array}$ \\
\hline
\end{tabular}


DOE/RL-97-55

Revision 0

May 28, 1998

\begin{tabular}{|l|c|l|}
\hline \multicolumn{1}{|c|}{ Project title } & Project number & \multicolumn{1}{c|}{ Interface } \\
\hline $\begin{array}{l}\text { Management and Economic } \\
\text { Transition Division }\end{array}$ & -- & $\begin{array}{l}\text { To seek beneficial uses for excess materials, equipment, and } \\
\text { facilities }\end{array}$ \\
\hline HAMMER & RL-HM01 & For personnel training support \\
\hline $\begin{array}{l}\text { Other DOE sites and offsite } \\
\text { entities }\end{array}$ & -- & $\begin{array}{l}\text { For the continued receipt of special nuclear material and nuclear } \\
\text { material }\end{array}$ \\
\hline SNF Project & RL-WM01 & $\begin{array}{l}\text { Advanced Reactors Transition, RL-TP11, for FFTF fuel and } \\
\text { 400 Area ISA operations (Advanced Reactors Transition provides } \\
\text { operation of the ISA and the SNF Project concurs with packaging } \\
\text { methods to facilitate final turnover of packaged fuel); } \\
\text { 324/327 Facility Transition, RL-TP08, for fuel stored in the 324 } \\
\text { and 327 Buildings; PFP Vault Management, RL-TP08, for fuel to } \\
\text { be stored in PFP }\end{array}$ \\
\hline S\&M & RL-ER05 & $\begin{array}{l}\text { To transfer deactivated facilities ready for long-term S\&M and/or } \\
\text { D\&D }\end{array}$ \\
\hline
\end{tabular}

$\begin{array}{ll}\text { D\&D } & =\text { decontamination and decommissioning } \\ \text { DOE } & =\text { U.S. Department of Energy } \\ \text { FFTF } & =\text { Fast Flux Test Facility } \\ \text { HAMMER } & =\text { Hazardous Materials Management and Emergency Response } \\ \text { ISA } & =\text { Interim Storage Area } \\ \text { LLW } & =\text { low-level waste } \\ \text { PFP } & =\text { Plutonium Finishing Plant } \\ \text { S\&M } & =\text { surveillance and maintenance } \\ \text { SNF } & =\text { spent nuclear fuel }\end{array}$

4.2.4.1.8 Logic Diagram. The FSP deactivation plans typically outline the overall approach to deactivate covered facilities. Material storage, treatment, and disposition strategies are often outlined in specific material management plans. Project schedules capture the logical relationships between work activities.

The Hanford Site Technical Baseline Database will be used to capture high-level logic relationships between FSP deactivations and material storage, treatment, and disposition subprojects. The FSP subproject execution will be modeled to ensure that interfaces necessary to support and/or facilitate execution are viable.

Figure 4-6 shows the decision process followed to determine who should perform decommissioning.

4.2.4.1.9 Requirements References. The FSP has the following mission analysis documents that define individual subproject missions and describe how they support the overall Hanford Site cleanup mission:

- WHC-SD-CP-MAR-003, Mission Analysis Report: Deactivating Facilities at Hanford (Lund 1996) 


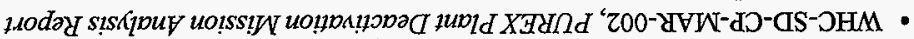
UOISSILV K4!I!DD

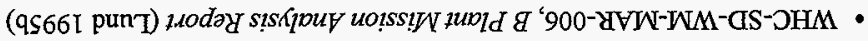

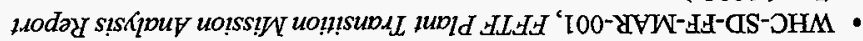

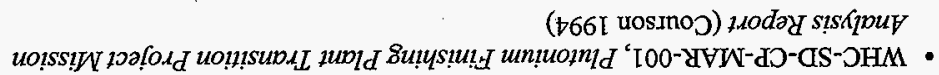

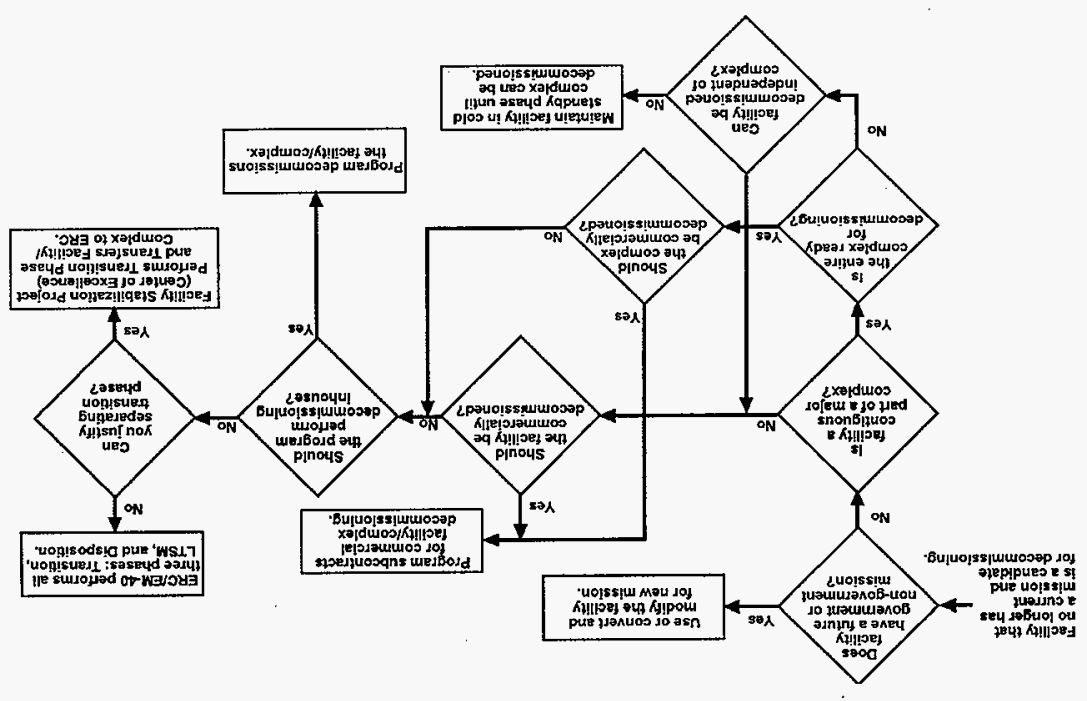

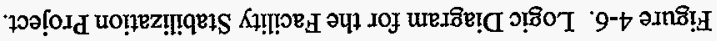


DOE/RL-97-55

Revision 0

- WHC-SD-FL-MAR-002, 300 Area Fuel Supply Facilities Deactivation Mission Analysis Report (Lund 1995g).

Other mission analysis documents shall be developed as necessary to define future deactivation projects.

The FSP has the following function analysis documents that define "what" the subprojects must do to satisfy their individual missions:

- WHC-SD-FL-FAR-001, 308 Building Deactivation Function Analysis Report (Lund 1995h)

- WHC-SD-SP-FAR-001, 309 Building Deactivation Function Analysis Report (Lund 1995i)

- WHC-SD-FL-FAR-002, 300 Area Fuel Supply Facilities Deactivation Function Analysis Report (Lund 1995j)

- WHC-SD-FF-FAR-001, FFTF Plant Transition Function Analysis Report (Lund 1995k)

- WHC-SD-WM-FAR-001, B Plant Function Analysis Report (Lund 19951)

- WHC-SD-WM-FAR-002, Waste Encapsulation and Storage Facility Function Analysis Report (Lund 1995m)

- WHC-SD-CP-FAR-001, Plutonium Finishing Plant Transition Project Function Analysis Report (Lund 1995n)

- WHC-SD-CP-FAR-002, PUREX Plant Deactivation Function Analysis Report (Lund 19950).

Other function analysis documents shall be developed as necessary to define future deactivation projects.

4.2.4.1.10 Issues. Facility life-cycle planning needs to be performed by programs and contractors occupying and operating government-contaminated facilities. The timing of mission completion in contaminated facilities needs to be defined so FSP can perform outyear planning and begin negotiations with EM-40 for outyear acceptance of deactivated facilities.

Subproject-specific issues are discussed in their respective sections. 


\subsubsection{B Plant Subproject.}

4.2.4.2.1 Project Description Summary. The mission of the B Plant Subproject is to place B Plant and its ancillary facilities (referred to as B Plant throughout this document) into a safe and stable condition that requires minimal long-term $S \& M$, thereby reducing the risks associated with the current radiological and chemical inventory and the costs for S\&M until disposition. Transition includes removal of stored radioactive and hazardous materials, safe shutdown of support systems such as electrical circuits and ventilation, and installation of new or modified systems required to support S\&M for a 10-year period. The WESF will be isolated from B Plant for standalone operation. Upon completion of transition, B Plant will be turned over to EM-40 for the S\&M phase.

Currently available technologies will be applied in innovative ways to support the B Plant mission. Freed-up intellectual and physical resources will be applied to other Hanford Site mission objectives.

In addition to FSP objectives listed in Section 4.2.4, the B Plant Subproject has the following objectives.

- Stabilize materials and either safely store and maintain them in place or remove them as waste.

- Reduce S\&M for B Plant by $90 \%$ upon completion of deactivation.

- Provide independent operating systems and services for WESF that permit deactivation of B Plant systems and elimination of B Plant services.

- Complete B Plant deactivation and turn over B Plant in FY 1999 for cost-effective, long-term S\&M in accordance with the baseline schedule.

- Eliminate or mitigate major hazards.

- Ensure control and operability of systems and equipment required to support postdeactivation S\&M for a 10 -year period.

- Maintain ES\&H compliance.

All deactivation end points will have been met at the completion of transition. The B Plant will be unoccupied and locked, and hazards will have been removed or mitigated to an acceptable risk level. Systems and utilities within the associated confinement structures will be deactivated unless they are required to support the S\&M phase of B Plant decommissioning. Periodic surveillance will be performed for industrial SAS. Required monitoring or operation of active systems (such as canyon ventilation) will be done remotely, with active components located outside the confinement structures to the extent practicable. The only required routine maintenance activity is anticipated to be associated with the canyon ventilation. 


\subsection{Geographic Requirements/Assumptions.}

\section{Requirements:}

- None.

Planning Assumptions: The B Plant Subproject supports Comprehensive Land Use Plan goals by performing the following activities.

- Move rapidly toward a minimum cost, safe storage mode pending transfer to EM-40 expediting the reduction of most salient hazards and shutting down and stabilizing operational systems. Maintain the facilities and perform work in a safe, secure, and environmentally compliant manner throughout the life of the project.

- Continue to provide safe storage support for $\mathrm{Cs} / \mathrm{Sr}$ capsules in WESF until it is decoupled from B Plant.

- Isolate B Plant from WESF to allow deactivation to proceed without impacting WESF operation. Continue to develop B Plant deactivation plans and associated documentation. Transition B Plant to a minimum S\&M cost and effect an orderly turnover to $\mathrm{EM}-40$.

- Maintain the B Plant safety and compliance envelope during deactivation. Keep the B Plant complex residual chemical and nuclear inventories in a safe, environmentally sound, cost-effective condition. Maintain safe and compliant operations, trained personnel, and supporting documentation.

- Establish deactivation plans and end point criteria, design the deactivation state, and negotiate turnover with EM-40. Establish and maintain project baselines.

\subsection{Material and Waste Flow Requirements/Assumptions.}

\section{Requirements:}

- None.

\section{Planning Assumptions:}

- B Plant contains approximately 85,000 to $250,000 \mathrm{Ci}$ of ${ }^{137} \mathrm{Cs}$ and ${ }^{90} \mathrm{Sr}$ in its ventilation system high-efficiency particulate air filters, up to approximately $2,000,000 \mathrm{Ci}$ of residual contamination in the canyon, and up to approximately $2,000,000 \mathrm{Ci}$ in contaminated equipment. 


\subsection{Facility Life-Cycle Requirements/Assumptions.}

\section{Requirements:}

- None.

Planning Assumptions: A facility assignment matrix showing facility ownership assignment for life-cycle phases is shown in the following table. The life-cycle phases are those identified in DOE Order 430.1, Life-Cycle Asset Management (DOE 1995c).

\begin{tabular}{|c|c|c|c|c|c|c|c|c|c|}
\hline \multirow{3}{*}{ Complex/facility } & \multicolumn{9}{|c|}{ Life cycle } \\
\hline & \multirow{2}{*}{$\begin{array}{l}\text { Program } \\
\text { planning }\end{array}$} & \multirow[b]{2}{*}{ Preconceptual } & \multirow[b]{2}{*}{ Conceptual } & \multicolumn{3}{|c|}{ Execute } & \multirow{2}{*}{$\begin{array}{c}\text { Ops and } \\
\text { maint }\end{array}$} & \multicolumn{2}{|c|}{ Close out } \\
\hline & & & & Design & Construct & Turnover & & $\begin{array}{c}\text { Post- } \\
\text { operation }\end{array}$ & D\&D \\
\hline B Plant & RL-TP01 & -- & $\cdots$ & $\cdots$ & $-\cdot$ & $\cdots$ & -- & $\begin{array}{l}\text { RL-TP01 } \\
\text { RL-ER05 }\end{array}$ & $\begin{array}{l}\text { RL-ER06 } \\
\text { RL-ER07 }\end{array}$ \\
\hline
\end{tabular}

$\mathrm{D} \& \mathrm{D}=$ decontamination and decommissioning

4.2.4.2.5 Project Safety Authorization Basis. Deactivation activities shall be evaluated against the approved safety authorization basis to identify any potential USQs. If the activity is shown to fall within the bounds of the safety authorization basis, additional approval is not required. If the activity is not covered, the work plans must be modified to stay within the bounds of the existing safety authorization basis or the change and activity must be approved by RL before the activity may proceed. Once approved by RL, the new analysis shall become part of the approved safety basis. The existing safety basis for B Plant is contained within the following documents:

- WHC-SD-WM-ISB-008, B Plant Interim Safety Basis (Chalk 1996a)

- WHC-SD-WM-SARR-030, B Plant Interim Safety Basis Accident Analysis (Chalk 1996b)

- WHC-SD-WM-TM-004, B Plant Facility Description (Chalk 1996c)

- WHC-SD-WM-FHA-021, B Plant Fire Hazard Analysis (Sepahur 1996).

Environmental, safety, and health requirements for B Plant are contained in the S/RID for B Plant.

\subsection{Other Requirements and Planning Assumptions.}

\section{Requirements:}

- None. 
Planning Assumptions: Several deactivation tasks will be required regardless of the details of the final end points. These activities can be planned and initiated early in the transition planning phase of $B$ Plant decommissioning, in parallel with preparation of the final end points. Those early decisions that have been determined to fit these criteria, and are proceeding in parallel with end point development, are as follows.

- It is assumed that the organic can be decontaminated to a radioactive level that is low enough to allow subsequent offsite shipment for either disposition or other beneficial use.

- Removal of radioactive and hazardous liquids from B Plant tanks and vessels, similar to PUREX, is assumed and has been completed, in parallel with the development of a final management strategy and associated end points.

- The need for an operating canyon ventilation system is an early assumption to support the S\&M phase of B Plant decommissioning. Retired, underground, B Plant canyon filters contain a large inventory of radioactive $\mathrm{Sr}$ and $\mathrm{Cs}$. The filter design prevents total isolation of loaded filters because the retired filters and the active filter share a common inlet plenum. In addition, it is assumed that an end point will require that the outlet water seals be replaced with an alternative, more permanent method of isolation. An early assumption has been made to isolate the retired/old filter banks and to construct a new system under Project W-059. This will place the retired filters into a safe, stable shutdown condition for the S\&M phase pending their ultimate disposition.

- The isolation or "decoupling" of WESF from B Plant will be needed to complete the B Plant Transition Project. The B Plant currently supports the WESF mission by supplying deionized water, receiving and disposing of liquid LLW, receiving solid waste, and receiving and monitoring effluent streams. The deionized water needs for the WESF pool cells will be met by a new system or service contract provided exclusively for WESF, allowing deactivation of the large deionized water system in B Plant. Liquid LLW generated in WESF will be collected and disposed to tank farms or an alternate disposal site, as appropriate. Solid waste generated at WESF will be packaged for direct transport to burial grounds or storage facilities operated by Solid Waste. Liquid effluents generated by WESF will be reduced and rerouted to flow directly to the 200 Area TEDF through a combination of building a new closed-loop cooling system for WESF (Project W-252) and tie-in to the chemical sewer stream. This will allow for isolation of B Plant liquid effluents and provide the capability to handle WESF liquid effluents independent of B Plant.

- The B Plant currently relies on steam to operate solution transfer jets, steam heaters for process and building heat, and steam-driven backup ventilation systems. Steam reliance shall be eliminated to reduce the costs of operating and maintaining the steam supply systems. 
- Routine maintenance and operations at B Plant require work in radiologically contaminated areas. Contaminated or potentially contaminated areas involve extra cost and hazard exposure to workers compared to uncontaminated areas. Cost and hazard exposure will be reduced by reducing B Plant radiological contamination areas.

4.2.4.2.7 Interfaces. The B Plant currently supports the WESF mission by supplying deionized water, receiving and disposing of liquid LLW, receiving solid waste, and receiving and monitoring effluent streams.

\begin{tabular}{|l|c|l|}
\hline \multicolumn{1}{|c|}{ Project title } & Project number & \multicolumn{1}{c|}{ Interface } \\
\hline Solid Waste Storage \& Disposal & RL-WM03 & For disposition of LLW and TRU waste \\
\hline Liquid Waste Program & RL-WM05 & For disposition of liquid effluents \\
\hline Retrieval & RL-TW04 & For disposition of tank waste after FY 2005 \\
\hline Tank Farm Operations & RL-TW03 & For disposition of tank waste through FY 2005 \\
\hline Analytical Services & RL-WM06 & For sample analysis and other laboratory support \\
\hline $\begin{array}{l}\text { Management and Economic } \\
\text { Transition Division }\end{array}$ & - - & $\begin{array}{l}\text { To seek beneficial uses for excess materials, equipment, and } \\
\text { facilities }\end{array}$ \\
\hline Landlord & RL-TP13 & $\begin{array}{l}\text { To supply infrastructure support and accept sanitary waste and } \\
\text { other landfill waste materials }\end{array}$ \\
\hline HAMMER & RL-HM01 & For personnel training support \\
\hline S\&M & RL-ER05 & $\begin{array}{l}\text { To transfer deactivated facilities ready for long-term S\&M } \\
\text { and/or D\&D }\end{array}$ \\
\hline
\end{tabular}

$\begin{array}{ll}\text { D\&D } & =\text { decontamination and decommissioning } \\ \text { FY } & =\text { fiscal year } \\ \text { HAMMER } & =\text { Hazardous Materials Management and Emergency Response } \\ \text { LLW } & =\text { low-level waste } \\ \text { S\&M } & =\text { surveillance and maintenance } \\ \text { TRU } & =\text { transuranic }\end{array}$

\subsection{Requirements References.}

- WHC-SD-HT-PCE-002, Life Cycle Cost Estimate for the B Plant Transition Project (WHC 1996a)

- WHC-SD-WM-TPP-054, B Plant End Point Document (Stefanski 1997)

- WHC-SD-WM-ISB-008, B Plant Interim Safety Basis (Chalk 1996a).

\subsection{Issues. None.}




\subsubsection{WESF Subproject.}

4.2.4.3.1 Project Description Summary. Approximately 146 million curies of ${ }^{137} \mathrm{Cs}$ and ${ }^{90} \mathrm{Sr}$ and their daughter products are contained in capsules currently stored in WESF in the 200 East Area. This two-story structure is next to the west wall of B Plant. The B Plant currently supplies cooling water and deionized water, and accepts liquid LLW streams, liquid effluents, and solid waste from WESF.

The WESF mission is to maintain and upgrade the facility to safely store $\mathrm{Cs} / \mathrm{Sr}$ capsules while requiring minimal S\&M. The WESF and its equipment may need to be improved and modernized to provide this safe storage. Storage will be provided until all the $\mathrm{Cs} / \mathrm{Sr}$ capsules have been received and dispositioned for disposal or beneficial uses. Buildings and equipment not required for these activities will be deactivated in preparation for D\&D activities. Currently available technologies will be resourcefully applied to maintain and upgrade WESF. This mission will support the Hanford Site cleanup mission statement from WHC-EP-0722, System Engineering Functions and Requirements for the Hanford Cleanup Mission: First Issue (Holmes 1994).

In addition to FSP objectives listed in Section 4.2.4, WESF mission objectives are as follows.

- Consolidate $\mathrm{Cs} / \mathrm{Sr}$ capsules at WESF for safe and compliant interim storage until their transfer to TWRS for final disposition.

- Maintain the WESF complex residual chemical and nuclear inventories in a safe, environmentally sound, cost-effective condition.

- Make available inactive facilities for other beneficial uses or prepare them for eventual deactivation and $\mathrm{D} \& \mathrm{D}$.

- Update and maintain the current configuration of all essential drawings for functioning safety-related systems and equipment.

\subsection{Geographic Requirements/Assumptions.}

\section{Central Plateau}

The WESF Subproject will support the Comprehensive Land Use Plan goals by performing the following activities.

- Maintain the safety envelope for ${ }^{137} \mathrm{Cs}$ and ${ }^{90} \mathrm{Sr}$. Repair the WESF structure and system components as necessary to maintain their safe operability and function. Replace structure and system components as required based on evaluations of the facility life cycle and shutdown date. Perform physical facility maintenance, operations, and documentation to ensure compliance. 
- Control ${ }^{137} \mathrm{Cs}$ and ${ }^{90} \mathrm{Sr}$. Define treatment, storage, and transfer needs for the materials and perform planning, coordination, and scheduling of necessary operations. Identify the steps to define and implement the transfer of the $\mathrm{Cs} / \mathrm{Sr}$ capsules to the High-Level Waste Disposal Program for final disposition. Recommend and adopt a preferred transfer method, and define subsequent objectives and plans. Update the existing Safety Analysis Report (WHC-SD-WM-SAR-005 [Covey 1996]) as necessary to accommodate continued receipt of $\mathrm{Cs}$ and $\mathrm{Sr}$.

- Receive Cs and Sr from other locations. Maintain the capability to unload, inspect, and transfer custody of $\mathrm{Cs}$ and $\mathrm{Sr}$ material to WESF.

- Safely store Cs and Sr until final disposition. Maintain the capability to identify, isolate, recover, and rework failed material. Reencapsulate failed and suspect capsules into a configuration acceptable for WESF pool cell storage. Continue safe, wet storage of the $\mathrm{Cs} / \mathrm{Sr}$ capsules until either an alternate dry storage location and storage methodology is identified or they are transferred to the High-Level Waste Disposal Program for final disposition.

- Decouple WESF from B Plant to make it a standalone facility.

- Maintain the U.S. Nuclear Regulatory Commission and DOE Certificates of Compliance for the Beneficial Uses Shipping System cask and maintain the cask in a state of readiness for use.

- Transfer outgoing materials for disposition. Maintain the capability to retrieve, load, and transfer $\mathrm{Cs}$ and $\mathrm{Sr}$ material for final disposition.

- Plan the transition of WESF and its ancillary facilities to a safe and cost-effective S\&M configuration and initiate transition efforts to effect an orderly turnover to EM-40 according to an integrated baseline schedule.

4.2.4.3.3 Material and Waste Flow Requirements/Assumptions. Approximately 146 million curies of ${ }^{137} \mathrm{Cs}$ and ${ }^{90} \mathrm{Sr}$ and their daughter products are contained in $1,315 \mathrm{Cs}$ and $601 \mathrm{Sr}$ capsules currently stored in WESF in the 200 East Area. The WESF ventilation high-efficiency particulate air filters also contain approximately $20,000 \mathrm{Ci}$ of ${ }^{137} \mathrm{Cs}$ and ${ }^{90} \mathrm{Sr}$, and approximately $100,000 \mathrm{Ci}$ of ${ }^{137} \mathrm{Cs}$ and ${ }^{90} \mathrm{Sr}$ in eight hot cells.

\subsection{Facility Life-Cycle Requirements/Assumptions.}

\section{Requirements:}

- None.

Planning Assumptions: A facility assignment matrix showing facility ownership assignment for life-cycle phases is shown in the following table. The life-cycle phases are those identified in DOE Order 430.1, Life-Cycle Asset Management (DOE 1995c). 


\begin{tabular}{|c|c|c|c|c|c|c|c|c|c|}
\hline \multirow{3}{*}{ Complex/facility } & \multicolumn{9}{|c|}{ Life cycle } \\
\hline & \multirow{2}{*}{$\begin{array}{l}\text { Program } \\
\text { planning }\end{array}$} & \multirow[b]{2}{*}{ Preconceptual } & \multirow[b]{2}{*}{ Conceptual } & \multicolumn{3}{|c|}{ Execute } & \multirow{2}{*}{$\begin{array}{l}\text { Ops and } \\
\text { maint }\end{array}$} & \multicolumn{2}{|c|}{ Close out } \\
\hline & & & & Design & Construct & Turnover & & $\begin{array}{c}\text { Post- } \\
\text { operation }\end{array}$ & $\mathrm{D} \& \mathrm{D}$ \\
\hline $\begin{array}{l}\text { Waste Encapsulation } \\
\text { and Storage Facility }\end{array}$ & RL-TP02 & -- & $\cdots$ & -. & $\cdots$ & $\cdots$ & RL-TPO2 & $\begin{array}{l}\text { RL-TP02 } \\
\text { RL-ER05 }\end{array}$ & $\begin{array}{l}\text { Rr-ER06 } \\
\text { RL-ER07 }\end{array}$ \\
\hline
\end{tabular}

$\mathrm{D} \& \mathrm{D}=$ decontamination and decommissioning

4.2.4.3.5 Project Safety Authorization Basis. The safety authorization basis for WESF is contained in WHC-SD-WM-SAR-005 (Covey 1997).

The WESF operations, safety, and maintenance activities shall be managed in accordance with FSP-WESF-5-6, Waste Encapsulation and Storage Facility (WESF) Administration Manual (FDH 1997a).

Environmental, safety, and health requirements for WESF are contained in the S/RWD for WESF.

\subsection{Other Requirements and Planning Assumptions.}

\section{Requirements:}

- None.

\section{Planning Assumptions:}

- Capsules will continue to be stored in WESF until they are shipped out for final disposition. Final disposition will be via vitrification at the Hanford Site starting in accordance with a coordinated baseline schedule.

- The WESF will be transformed into a modern pool cell storage facility resulting in a significantly lowered annual cost for storage. This includes decontamination and deactivation of structures and systems in place as a result of the legacy program for encapsulation of Sr and Cs.

\subsection{Interfaces.}

\begin{tabular}{|l|c|l|}
\hline \multicolumn{1}{|c|}{ Project title } & Project number & \multicolumn{1}{c|}{ Interface } \\
\hline Solid Waste Storage \& Disposal & RL-WM03 & For disposition of LLW and TRU waste \\
\hline Liquid Waste Program & RL-WM05 & For disposition of liquid effluents \\
\hline $\begin{array}{l}\text { Immobilized Tank Waste Storage } \\
\text { \& Disposal }\end{array}$ & RL-TW09 & For final disposition of Cs/Sr capsules \\
\hline Analytical Services & RL-WM06 & For sample analysis and other laboratory support \\
\hline
\end{tabular}


DOE/RL-97-55

Revision 0

May 28, 1998

\begin{tabular}{|l|c|l|}
\hline \multicolumn{1}{|c|}{ Project title } & Project number & \multicolumn{1}{|c|}{ Interface } \\
\hline $\begin{array}{l}\text { Management and Economic } \\
\text { Transition Division }\end{array}$ & -- & $\begin{array}{l}\text { To seek beneficial uses for excess materials, equipment, and } \\
\text { facilities }\end{array}$ \\
\hline Landlord & RL-TP13 & $\begin{array}{l}\text { To supply infrastructure support and accept sanitary waste } \\
\text { and other landfill waste materials }\end{array}$ \\
\hline HAMMER & RL-HM01 & For personnel training support \\
\hline 324/327 Facility Transition Project & RL-TP08 & For the continued receipt of ${ }^{137} \mathrm{Cs}$ and ${ }^{90} \mathrm{Sr}$ \\
\hline $\begin{array}{l}\text { Immobilized Tank Waste Storage } \\
\text { \& Disposal }\end{array}$ & RL-TW09 & For disposition of Cs/Sr capsules \\
\hline S\&M & RL-ER05 & $\begin{array}{l}\text { To transfer deactivated facilities ready for long-term S\&M } \\
\text { and/or D\&D }\end{array}$ \\
\hline
\end{tabular}

$\mathrm{D} \& \mathrm{D}=$ decontamination and decommissioning

HAMMER = Hazardous Materials Management and Emergency Response

LLW = low-level waste

S\&M = surveillance and maintenance

TRU = transuranic

\subsection{Requirements References.}

- WHC-SD-HT-PCE-004, Life Cycle Cost Estimate for the WESF Project (WHC 1996b)

- Draft WESF BIO.

4.2.4.3.9 Issues. None.

\subsubsection{300 Area/SNM Subproject.}

4.2.4.4.1 Project Description Summary. The 300 Area Fuel Supply Facilities consist of 15 facilities, a utility trench, storage tanks, and a mobile office. A burial ground is within the 333 Building security fence. The Fuel Supply Facilities Shutdown Plan (WHC 1994) describes the status and direction of shutdown activities. Deactivation of these facilities has been separated into three major activities:

- Storage and disposition of SNM

- Completion of work defined in the RCRA Closure Plans for designated facilities, systems, or areas

- Shutdown and cleanup of all the remaining facilities, systems, and areas for turnover to D\&D. Because of the low hazards, the remaining scope of work is covered by an approved NEPA categorical exclusion. 
The purpose of the 300 Area Fuel Supply Facilities Deactivation Project is to establish a passively safe and environmentally secure low-cost and stable configuration of the 300 Area Fuel Supply Facilities, and turn over the 300 Area Fuel Supply Facilities to D\&D. The project removes, reduces, and/or stabilizes the SNM and major remaining radioactive sources and hazardous chemicals within and around the 300 Area Fuel Supply Facilities. There will be no active systems or utilities within the facilities. During deactivation, appropriate portions of the safety envelope shall be maintained to ensure deactivation takes place in a safe and regulatorycompliant manner.

In addition to objectives listed in Section 4.2.4, the 300 Area Fuel Supply Deactivation Project objectives include the following.

- Establish a passively safe and environmentally secure configuration of the facilities (no active internal functions or equipment within confinement), and retain that configuration until turnover to D\&D.

- Achieve a total yearly cost target of $\$ 1.6$ million/year at turnover.

- Implement cost-effective, innovative approaches to ensure the required safety envelope is defined and maintained during deactivation. Apply lessons learned from commercial deactivation experience.

- Establish the 300 Area Fuel Supply Facilities Deactivation Project as a model for $U$ fuel fabrication facilities deactivations.

- Continue safe storage of 300 Area SNM and 200 West Area $\mathrm{UO}_{3}$ solutions.

4.2.4.4.2 Geographic Requirements/Assumptions. This project will support Comprehensive Land Use Plan goals by performing the following activities.

- Deactivate the 300 Area Fuel Supply Facilities plants (16 buildings in the northeast corner of the 300 Area) and related plant utilities. Most of the effort will be the sale of NF materials to a commercial vendor, RCRA closure of two facilities and seven partial facilities, and cleanup and shutdown of all facilities (the two largest are the 313 and 333 Buildings) and surrounding areas.

- Maintain the Fuel Supply Shutdown (FSS) Facility in a regulatory-compliant state until turnover to EM-40 is completed. Perform shutdown activities as described in WHC-SD-FL-SSP-002, Shutdown Plon for the Fuel Supply Facilities (Metcalf 1996) and Fuel Supply Facilities deactivation end point criteria.

- Maintain compliant storage of 1,200 MT of SNM until dispositioned (such as sale, or declaration as waste).

- Isolate the 313 Building south portion with no access or utilities until turnover. 
- Upon completion of shutdown, RCRA activities, and SNM relocation (and/or disposition), all Fuel Supply buildings shall be ready to be transferred to EM-40.

\subsection{Material and Waste Flow Requirements/Assumptions.}

\section{Requirements:}

- None.

\section{Planning Assumptions:}

- Currently, SNM is stored in six buildings $(3712,3716,303 \mathrm{~A}, 303 \mathrm{~B}, 303 \mathrm{E}$, and $303 \mathrm{G})$. The total amount of SNM in these buildings is 1,200 MT of finished U fuel elements, partially finished fuel elements, and billets. (This U material consists of $0.71 \%$ [natural], $0.95 \%$, and $1.25{ }^{235} \mathrm{U}$ enrichments.) In addition, $3.4 \mathrm{MT}$ of U powder and $0.47 \mathrm{MT}$ of Th powder require disposition and are stored in the south portion of the 303K Building. Security, protection, and accountability will be required until an another storage location is available.

- Uranium trioxide solutions shall be safely stored in their current 200 West Area location until they are transferred to another site location or transferred to other beneficial uses. If the $\mathrm{UO}_{3}$ is transferred to another location, it shall be safely stored there until it is transferred to other beneficial uses. Other beneficial uses shall be sought while the material is being stored. Uranium trioxide remaining onsite after the date specified in the integrated baseline schedule shall be packaged for onsite burial.

\subsection{Facility Life-Cycle Requirements/Assumptions.}

\section{Requirements:}

- None.

Planning Assumptions: A facility assignment matrix showing facility ownership assignment for life-cycle phases is shown in the following table. The life-cycle phases are those identified in DOE Order 430.1, Life-Cycle Asset Management (DOE 1995c).

\begin{tabular}{|c|c|c|c|c|c|c|c|c|c|}
\hline \multirow{3}{*}{ Complex/facility } & \multicolumn{9}{|c|}{ Life cycle } \\
\hline & \multirow{2}{*}{$\begin{array}{l}\text { Program } \\
\text { planning }\end{array}$} & \multirow[b]{2}{*}{ Preconceptual } & \multirow[b]{2}{*}{ Conceptual } & \multicolumn{3}{|c|}{ Execute } & \multirow{2}{*}{$\begin{array}{l}\text { Ops and } \\
\text { maint }\end{array}$} & \multicolumn{2}{|c|}{ Close out } \\
\hline & & & & Design & Construct & Turnover & & $\begin{array}{c}\text { Post- } \\
\text { operation }\end{array}$ & $D \& D$ \\
\hline $\begin{array}{l}300 \text { Area Fuel } \\
\text { Supply Facilities }\end{array}$ & RL-TP04 & -- & - - & 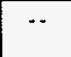 & - & -- & RI-TP04 & RL-TP04 & RL-ER06 \\
\hline
\end{tabular}

$\mathrm{D} \& \mathrm{D}=$ decontamination and decommissioning 
4.2.4.4.5 Project Safety Authorization Basis. The authorization basis for the 300 Area Fuel Supply facilities is contained in WHC-SD-NR-ISB-001 (Benecke 1995a) and in WHCSD-NR-TSR-001 (Benecke 1995b). The 300 Area Fuel Supply facility transition operations shall be in accordance with WHC-SD-NR-TSR-001 and FSP-FSS-5-35, Fuels Supply Operations Control Mamual (FDH 1998b).

\subsection{Other Requirements and Planning Assumptions.}

\section{Requirements:}

- None.

\section{Planning Assumptions:}

- Resource Conservation and Recovery Act of 1976 implementation activities shall continue to be carried out in accordance with the following RCRA closure plans: DOE/RL-90-04, 303K Storage Facility Closure Plan (Adler 1994) and DOE/RL-9011, The 300 Area Waste Acid Treatment System (WATS) Closure Plan (Luke 1996).

- The closure plans describe the sampling, characterization, and investigative studies to be performed in these facilities; defines their hazard potential; and identifies required corrective actions. Remediation work is expected to be required; soil cleanup under CERCLA may be needed before the facilities can be defined as closed.

- The Waste Acid Treatment Plan is listed in the Hanford Facility RCRA Permit Appendix 27, for inclusion in MOD D of the permit.

- The 300 Area FSS facilities are within 300-FF-3 (source) and 300-FF-5 (groundwater) operable units, as designated in the Tri-Party Agreement (Ecology et al. 1996). The 300-FF-3 and 300-FF-5 operable units are scheduled to be remediated using the CERCLA remediation investigation and feasibility study process. Therefore, any soil and groundwater contamination not related to the RCRA closure plan activities will be deferred to the CERCLA remediation investigation and feasibility study process. The 300 Area Facility 303M RCRA closure plan has not been prepared, but is deferred to the 300-FF-3 (CERCLA) Operable Unit (M-20-92-05).

- Any inventory of SNM that cannot be dispositioned through sale to a commercial vendor will be declared waste and packaged for disposal.

\subsection{Interfaces.}

\begin{tabular}{|l|c|l|}
\hline \multicolumn{1}{|c|}{ Project title } & Project number & \multicolumn{1}{|c|}{ Interface } \\
\hline $\begin{array}{l}\text { Solid Waste Storage \& } \\
\text { Disposal }\end{array}$ & RL-WM03 & For disposition of LLW, TRU waste, and liquid effluents \\
\hline Liquid Waste Program & RL-WM05 & For disposition of LLW, TRU waste, and liquid effluents \\
\hline
\end{tabular}


DOE/RL-97-55

Revision 0

\begin{tabular}{|l|c|l|}
\hline \multicolumn{1}{|c|}{ Project title } & Project number & \multicolumn{1}{c|}{ Interface } \\
\hline Analytical Services & RL-WM06 & For sample analysis and other laboratory support \\
\hline $\begin{array}{l}\text { Management and Economic } \\
\text { Transition Division }\end{array}$ & - & $\begin{array}{l}\text { To seek beneficial uses for excess materials, equipment, and } \\
\text { facilities }\end{array}$ \\
\hline Landlord & RL-TP13 & $\begin{array}{l}\text { To supply infrastructure support and accept sanitary waste and } \\
\text { other landfill waste materials }\end{array}$ \\
\hline HAMMER & RL-HM01 & For personnel training support \\
\hline Other DOE sites & - - & For the continued receipt of SNM and NM \\
\hline S\&M & RL-ER05 & $\begin{array}{l}\text { To transfer deactivated facilities ready for long-term S\&M and/or } \\
\text { D\&D }\end{array}$ \\
\hline
\end{tabular}

$\begin{array}{ll}\text { D\&D } & =\text { decontamination and decommissioning } \\ \text { DOE } & =\text { U.S. Department of Energy } \\ \text { HAMMER } & =\text { Hazardous Materials Management and Emergency Response } \\ \text { LLW } & =\text { low-level waste } \\ \text { NM } & =\text { nuclear material } \\ \text { TRU } & =\text { transuranic } \\ \text { S\&M } & =\text { surveillance and maintenance } \\ \text { SNM } & =\text { special nuclear material }\end{array}$

\subsection{Requirements References.}

- WHC-SD-FL-SSP-002, Shutdown Plan for the 300 Area Fuel Supply Facilities (Metcalf 1996)

- WHC-SD-NR-ISB-001, Interim Safety Basis for Fuel Supply Shutdown Facility (Benecke 1995a)

- WHC-SD-NR-TSR-001, Fuel Supply Shutdown Facility Interim Operational Safety Requirements (Benecke 1995b)

- WHC-SD-NR-DB-004, End Point Criteria for Fuel Supply Shutdown Facilities (Ramaize 1996).

4.2.4.4.9 Issues. It is assumed that 303K RCRA closure can be delayed to FY 1998, but priority and resources will need to be applied because 303K is in the Part B Permit with a closure date of July 31, 1998.

\subsubsection{PFP Subprojects.}

4.2.4.5.1 Project Description Summary. The mission strategy for the PFP is to implement the ROD resulting from DOE/EIS-0244F, Plutonium Finishing Plant - Final Environmental Impact Statement (DOE 1996g). This currently entails the following activities. 
- Implement DNFSB Recommendation 94-1 (DNFSB 1994b) by safely stabilizing reactive scrap inventories, initiating terminal cleanout activities, implementing required capital upgrades, and stabilizing vault material by calcination or other methods as appropriate. These activities shall be completed and identified $\mathrm{Pu}$ vulnerabilities mitigated in accordance with deadlines established in the PFP integrated schedule baseline.

- Transition the production portions of the PFP Complex into a low-cost, stable deactivated state in accordance with the integrated schedule baseline. This includes implementation of ductwork remediation, glove box cleanout and removal, facility stabilization, and deactivation activities.

- Continue maintenance of the safety envelope for the PFP Complex as defined in approved Operational Safety Requirement documentation.

- Continue safe and secure operations of the PFP vault complex to receive, store, and ship SNM consistent with applicable federal, state, and international regulations and requirements until this material can be dispositioned.

- Complete scheduled upgrades and performance of activities as required to maintain a. safe and environmentally sound facility, and compliance with environmental regulations and compliance agreements.

4.2.4.5.2 Project Safety Authorization Basis. The authorization basis for PFP is contained in WHC-SD-CP-SAR-021 (Shapley 1995) and WHC-SD-CP-OSR-010 (Szempruch 1994). The PFP shall be operated in accordance with FSP-PFP-5-8, Plutonium Finishing Plant Administration (FDH 1997b).

Environmental, safety, and health requirements for PFP are contained in WHC-SD-MP-SRID-003, Plutonium Finishing Plant (PFP) Standards/Requirements Identification Document (S/RID) (Maddox 1996).

\subsection{Other Requirements and Planning Assumptions.}

\section{Requirements:}

- None.

Planning Assumptions: The following planning assumptions are common to all PFP subprojects.

- An activity-based cost estimate is the basis for the budget, and for all outyear work scope, budget, and schedule requests through FY 2003. This activity-based cost estimate incorporates all safety compliance issues into a systems engineering/project management approach. 
- Defense Programs (DP) will continue to provide funding of approximately $\$ 19$ million/year for continued storage and management of SNM fuels and materials inventories pending decisions on ultimate material disposition or storage. The work scope associated with vault operations and maintenance, SAS, NM accountability, patrol, etc., exceeds the DP funding provided. The work scope previously funded by DP will be funded by EM- 60 and any changes to the DP funding level will be associated with an equal and opposite change in the EM-60 funding level.

- No major changes in programmatic direction or regulatory status (e.g., permitting) are assumed as a result of ongoing Tri-Party Agreement negotiations.

- Facility modifications for minimum S\&M will continue.

- The facility will be maintained in a safe and compliant configuration.

- Work will be conducted in accordance with the Tri-Party Agreement and other agreements, and in compliance with all applicable federal, state, and local laws.

\subsubsection{PFP Deactivation.}

4.2.4.6.1 Project Description Summary. The initial PFP Deactivation Project mission is to provide for the safe and orderly terminal cleanout and deactivation of seven of the nine major facilities and their associated support structures at the PFP Complex. The major facilities that will not be deactivated at this time include 2736-ZB, Product Shipping and Receiving Facility, and $2736-Z$, Plutonium Storage Facility, due to their mission of safe and secure storage of NM. Use of these facilities is expected until at least 2025 at which time transfer of the material to a High-Level Waste Immobilization Facility will be initiated. The remaining facilities will then undergo terminal cleanout and be deactivated to an S\&M level by about FY 2028 and be maintained in a safe and compliant state pending final disposition.

The PFP facilities will be transitioned to a safe and stable condition that minimizes the long-term cost of an S\&M program that is protective of workers, the public, and the environment. All deactivation projects must be integrated with the activities required to support DNFSB 94-1 stabilization and continued vault operations. Specifically, the scope is composed of the following activities.

- Deactivate facilities to achieve safe, stable, low-cost S\&M before transfer to EM-40.

- Cleanup of PFP shall include stabilization and removal of the glove boxes. After removal of all readily retrieval $\mathrm{Pu}$ from the glove boxes, several options will be considered for glove box disposition. Disposition options include disposal to WIPP, decontamination to non-TRU, compaction for disposal in burial grounds or canyons, direct disposal in canyons, or other options not yet identified.

- Contamination on floors and walls, where removal is not feasible or cost-effective, shall be fixed in place and left for mitigation by the ERC. 
- Hazards to personnel, the public, or the environment shall be controlled through stabilization, removal, or isolation of structures, systems, and components and compensatory measures (barriers, access controls, administrative controls, etc.) as appropriate.

- Achieve an unoccupied facility classification of the PFP facilities, eventually including the $2736-\mathrm{Z}$ and $-\mathrm{ZB}$ facilities and required support facilities.

- Transfer all of the identified facilities to the ERC for post-deactivation surveillance and eventual D\&D.

In addition to the objectives listed in Section 4.2.4, PFP Transition Project objectives include the following.

- Implement the ROD from the PFP cleanout EIS.

- Implement the DOE DNFSB Recommendation 94-1 Program Plan to stabilize and store or discard all recovered Pu-bearing material.

- Safely and securely operate the PFP vault complex to receive, store, and ship SNM consistent with applicable federal, state, and international regulations and requirements.

- Continue to maintain a laboratory capability sufficient to support (1) the storage of SNM until disposition, and (2) facility deactivation activities (i.e., sample characterization, etc.).

- Maintain the infrastructure to preclude inadvertent radioactive material release.

\subsection{Geographic Requirements/Assumptions.}

\section{Requirements:}

- None.

\section{Planning Assumptions:}

This project supports achievement of the Central Plateau end state by performing the following:

- Mitigate vulnerabilities associated with residual contamination in facilities. Conceptual deactivation plans, including terminal cleanout, shall include the following major facilities and associated support facilities:

- 234-5Z Plutonium Fabrication Facility, Main Processing Building Cleanup and Transition 
- 236-Z Plutonium Reclamation Facility Cleanup and Transition

- 242-Z Waste Treatment Facility Cleanup and Transition

- 243-Z Low-Level Waste Treatment Facility Cleanup and Transition

- 241-Z Waste Treatment and Disposal Building Cleanup and Transition

- 291-Z Exhaust Ventilation Building and Exhaust Stack Cleanup and Transition

- Miscellaneous Buildings Cleanup and Transition

- Upgrade and maintain current infrastructure to support facility operations for stabilization, cleanout, and transition to a deactivated state.

- Continue development of deactivation plans and end point criteria.

- Methods to improve efficiency shall be explored and used as warranted.

- Applicable "lessons learned" from PUREX/UO ${ }_{3}$ FFTF, B Plant, 308 and 309 Facilities, the FERMCO site, and others in the United States and Sellafield experience from the United Kingdom shall be incorporated into planning and execution of the PFP Projects.

- Breakthrough technology will be factored into the planning to the extent warranted.

- Facility deactivation and decontamination options will be presented and will evaluate technologies used at other Hanford Site facilities and those available at other DOE and commercial sites (wet chemistry, hydro lasers, wipes, mechanical means, etc.). Preliminary assessments of NEPA and/or other required documentation (hazard analyses, FSAR, DOE Orders, etc.) will be performed relative to the proposed options to identify applicability and adequacy of existing PFP environmental documentation.

- Miscellaneous waste sites and cribs near PFP are NOT included in the current baseline.

- To ensure long-term safety and regulatory compliance, the following requirements apply.

- Permanent radiation zones to be entered for surveillance will be decontaminated and released or the surface contamination levels reduced or stabilized to minimize resuspension and/or migration of loose contamination. 
- Packaged radioactive and mixed waste with identified final disposition will be removed and disposed of in accordance with WAC 173-303, "Dangerous Waste Regulations." Wastes that are not removed will be identified, characterized, and documented.

- Glove boxes will be removed where possible. If removal is not possible, accessible interior glove box surfaces will be decontaminated or the surface contamination stabilized. Openings to glove boxes will be sealed in a way that ensures confinement of remaining contamination.

- Paint is not a suitable contamination barrier where exposed to the weather.

- Loose or damaged (friable) asbestos in areas expected to be entered during surveillance will be removed or stabilized.

- Fissile materials will be removed sufficiently to eliminate the potential for a nuclear criticality excursion and the need for a criticality alarm system.

- Tanks, vessels, and drums will be drained using installed equipment and features. Heels will not contain material classified as hazardous waste.

- Hazardous materials used for deactivation and cleanup work will be collected and disposed of in accordance with WAC 173-303.

- Emergency lighting will be deactivated and associated batteries will be removed from the facility.

4.2.4.6.3 Material and Waste Flow Requirements/Assumptions. Approximately $80 \mathrm{~kg}$ of Pu "holdup" are estimated to exist in ductwork, piping, cells, and glove boxes.

\subsection{Facility Life-Cycle Requirements/Assumptions.}

\section{Requirements:}

- None.

Planning Assumptions: A facility assignment matrix showing facility ownership assignment for life-cycle phases is shown in the following table. The life-cycle phases are those identified in DOE Order 430.1, Life-Cycle Asset Management (DOE 1995c). 
DOE/RL-97-55

\begin{tabular}{|c|c|c|c|c|c|c|c|c|c|}
\hline \multirow{3}{*}{ Complex/facility } & \multicolumn{9}{|c|}{ Life cycle } \\
\hline & \multirow{2}{*}{$\begin{array}{l}\text { Program } \\
\text { planning }\end{array}$} & \multirow[b]{2}{*}{ Preconceptual } & \multirow[b]{2}{*}{ Conceptual } & \multicolumn{3}{|c|}{ Execute } & \multirow{2}{*}{$\begin{array}{l}\text { Ops and } \\
\text { maint }\end{array}$} & \multicolumn{2}{|c|}{ Close out } \\
\hline & & & & Design & Construct & Turnover & & $\begin{array}{c}\text { Post- } \\
\text { operation }\end{array}$ & D\&D \\
\hline $\begin{array}{l}\text { Plutonium } \\
\text { Finishing Plant }\end{array}$ & RL-TP07 & - & $\cdots$ & -- & - & - & $\begin{array}{l}\text { RL-TP05 } \\
\text { RL-TP06 } \\
\text { RL-TP07 }\end{array}$ & $\begin{array}{l}\text { RL-TP05 } \\
\text { RL-TP07 } \\
\text { RL-ER05 } \\
\text { RL-TP06 }\end{array}$ & $\begin{array}{l}\text { RL-ER06 } \\
\text { RL-ER07 }\end{array}$ \\
\hline
\end{tabular}

$D \& D=$ decontamination and decommissioning

\subsection{Other Requirements and Planning Assumptions.}

\section{Requirements:}

- None.

\section{Planning Assumptions:}

- The PFP Deactivation Project shall be completed by the end of FY 2014 with the exception of the $2736-\mathrm{Z} / \mathrm{ZB}$ vault complex. Hazardous and radioactive materials shall be removed from the plants or stabilized in place to ensure long-term facility safety and regulatory compliance, enable plant classification as an unoccupied facility, and enable subsequent successful S\&M and ultimately D\&D.

- The overall objective of facility transition is to achieve a safe, stable, and environmentally sound condition, suitable for an extended period, as quickly and economically as possible. Once transitioned, the facility is kept in its stable condition by means of a methodical S\&M program implemented by the ERC, pending ultimate disposition. The acceptable facility interim state is defined by a set of end point criteria for that particular facility.

- Materials will be removed and/or stabilized sufficiently to ensure that the plant complies with WHC-CM-7-5, Environmental Compliance, and DOE/RL-96-109, Hanford Site Radiological Control Manual (RL 1997c), as applicable to an unoccupied facility after completion of deactivation. As a general guide, as-left contamination and radiation levels in plant areas will be no more than the levels encountered during normal operation and occupancy of the plants. End state matrix documents will be used to document structures, systems, and components' condition for turnover to ERC/EM-40.

- Permanent radiation zones to be entered for surveillance shall be decontaminated and released or the surface contamination levels reduced or stabilized to minimize resuspension and/or migration of loose contamination. Temporary radiation zones inside and outside the buildings will be eliminated. 
- No related upgrades to PFP dangerous waste tanks systems are required beyond those already planned.

- Solid waste at PFP is classified as nonregulated hazardous, low-level radioactive, TRU radioactive, and mixed (hazardous with radioactive constituents such as LLW and TRU).

- Stabilization and immobilization operations, in connection with terminal cleanout and deactivation, will continue until the end of the program in FY 2014.

- The current laboratory development program will identify and resolve any technology and equipment development issues and serve as an adequate basis for design of the selected stabilization process systems. The PFP Analytical Laboratory and the Plutonium Process Support Laboratories will be upgraded as required. Additional instrumentation will be provided to support necessary analyses in characterization of miscellaneous solid residues and process support of the stabilization operations.

- Programmatic operations will be on a 24-hour-per-day, 5-day-per-week basis (XYZ schedule) and personnel and funding will be provided to support this level of effort.

- The PFP Transition Project end point is anticipated by September 2014. This end point is NOT the cessation of all activities as with other Hanford Site facilities. Instead, this end point assumes the continued operation of all SNM shipping, receiving, and storage and vault systems, including all SAS systems, plus laboratory capabilities as needed, for an indefinite period but currently assumed to be approximately FY 2028. This end point condition is also based on the following.

- Full implementation of DNFSB Recommendation 94-1 will be completed in FY 2005 and applicable $\mathrm{Pu}$ vulnerabilities have been mitigated.

- Deactivation is initiated in FY 2001 in parallel with Recommendation 94-1 activities. Remaining facility transition to deactivation is initiated immediately following completion of DNFSB Recommendation 94-1 activities.

- Most of the facility transition to deactivation occurs during FY 2002 through FY 2014.

- Material Disposition accepts all material and transports it out of the PFP Complex by the end of FY 2028 .

4.2.4.6.6 Interfaces. PFP Deactivation interfaces with PFP Stabilization sharing resources, management, and engineering functions. Deactivation is subservient to Stabilization.

PFP Deactivation interfaces with PFP Vault Management. PFP Vault Management provides Operations Minimum Safe support to the International Atomic Energy Agency (IAEA) for Vault 3, and infrastructure tasks necessary to support PFP Deactivation. 
DOE/RL-97-55

Revision 0

May 28, 1998

\begin{tabular}{|c|c|c|}
\hline Project title & Project number & Interface \\
\hline Solid Waste Storage \& Disposal & RL-WM03 & For disposition of low-level waste and transuranic waste \\
\hline Liquid Waste Program & RL-WM05 & For disposition of liquid effluents \\
\hline Tank Farm Operations & RL-TW03 & For disposition of tank waste through FY 2005 \\
\hline Retrieval & RL-TW04 & For disposition of tank waste after FY 2005 \\
\hline Analytical Services & RL-WM06 & For sample analysis and other laboratory support \\
\hline $\begin{array}{l}\text { Management and Economic } \\
\text { Transition Division }\end{array}$ & - & $\begin{array}{l}\text { To seek beneficial uses for excess materials, equipment, and } \\
\text { facilities }\end{array}$ \\
\hline Landlord & RL-TP13 & $\begin{array}{l}\text { To supply infrastructure support and accept sanitary waste and } \\
\text { other landfill waste materials }\end{array}$ \\
\hline S\&M & RL-ER0S & $\begin{array}{l}\text { To transfer deactivated facilities ready for long-term } S \& M \\
\text { and/or D\&D }\end{array}$ \\
\hline
\end{tabular}

$D \& D=$ decontamination and decommissioning

FY $=$ fiscal year

$S \& M=$ surveillance and maintenance

\subsection{Requirements References.}

- WHC-SD-CP-SAR-021, Plutonium Finishing Plant Final Safety Analysis Report (Shapley 1995)

- WHC-SD-CP-SP-001, PRF Deactivation Summary Plan (Nelson 1996)

- DOE/EIS-0244F, Plutonium Finishing Plant - Final Environmental Impact Statement (DOE 1996g)

- 96-EAP-179, Plutonium Finishing Plant Stabilization Environmental Impact Statement Record of Decision (DOE 1996h)

- Draft Facility Deactivation End Points Handbook (DOE 1995f)

- DOE/EM-0246, Decommissioning Resource Mamual (DOE 1995g)

- Hanford Federal Facility Agreement and Consent Order (Ecology et al. 1996)

- WHC-SP-1126, Facility Stabilization Project Fiscal Year 1997 Multi-Year Work Plan (MYWP) for WBS 7.1 (Cartmell 1996)

- HNF-EP-0853, DNFSB Recommendation 94-1 Hanford Site Integrated Stabilization Management Plan (McCormack 1997).

4,2,4,6,8 Issues. The Hanford Site has 35 identified Pu ES\&H vulnerabilities of which 22 are associated with PFP. Seven of the identified vulnerabilities have been corrected. The 
remaining vulnerabilities will not be fully corrected until deactivation of the PFP Complex is complete by the end of FY 2014.

\subsubsection{PFP Stabilization.}

4.2.4.7.1 Project Description Summary. The PFP Stabilization Subproject mission is to implement DNFSB Recommendation 94-1 and correct related Pu vulnerabilities by stabilizing, repackaging, immobilizing, and/or properly dispositioning all remaining Pu-bearing materials in storage at the PFP. New hardware includes muffle furnaces, a vertical calciner, and pyrolysis equipment. Also included is Project W-460, a line item project at the PFP. This line item project is required to support the stabilization, packaging, and storage of Pu-bearing materials at PFP in accordance with the schedule and requirements of DNFSB Recommendation 94-1. This line item consists of two parts: (1) an automated Plutonium Stabilization and Packaging System; and, (2) 2736-Z Vault upgrades and 2736-ZB facility modifications, as necessary, to support the Stabilization and Packaging System and to be consistent with DOE-STD-3013-96 (DOE 1996i).

The PFP cleanout EIS and the corresponding ROD have been prepared and approved for stabilization and packaging activities at the PFP. Based on the approved ROD, stabilization and packaging activities are occurring to reduce risks in the facility resulting from previous DP $\mathrm{Pu}$ processing activities. These risks include, but are not limited to, stored reactive $P u$ residues, reactive Pu metals and oxides, deterioration of containers, and improperly packaged items.

The PFP Stabilization work scope includes the following primary activities at PFP: stabilization and packaging of Pu materials at the PFP consistent with the PFP final EIS and ROD; implementation of DNFSB Recommendation 94-1, Improved Schedule for Remediation in the Defense Nuclear Facilities Complex (DNFSB 1994b); and the resolution of the applicable identified PFP Pu vulnerabilities. These major activities all involve the handling, movement, and/or processing of $\mathrm{Pu}$ materials in some form and thereby present similar risks and consequences.

In addition to the objectives listed in Section 4.2.4, the following objectives clarify this project.

- The PFP Stabilization Subproject is completed when the Pu and U materials at PFP, as defined by DNFSB Recommendation 94-1, are dispositioned according to the requirements of the DOE's DNFSB Recommendation 94-1 Implementation Plan, transmitted to the DNFSB on February 28, 1995.

- Five of the 22 PFP Pu ES\&H vulnerabilities will be corrected through the stabilization and packaging activities required by the DNFSB Recommendation 94-1 Implementation Plan; the other vulnerabilities will be corrected as a part of Pu-handling facilities transition (deactivation) to the ER Project. Plutonium materials generated by the resolution of $\mathrm{Pu}$ vulnerabilities before October 2004 shall be dispositioned as part of the DNFSB 94-1 Program. 
- Stabilization, immobilization, and/or other disposition activities shall be conducted in accordance with the PFP baseline schedule.

\subsection{Geographic Requirements/Assumptions.}

\section{Requirements:}

- None.

Planning Assumptions: The PFP Stabilization Subproject supports achievement of the Central Plateau end state by performing the following activities.

- Operate and maintain PFP stabilization, packaging, and/or other disposition activities in a formal, safe, and secure manner in compliance with applicable regulations. Comply with DOE Orders 5400.5 (DOE 1990a), 5480.3 (DOE 1985), 5480.7A (DOE 1993), 5480.19 (DOE 1990b), 5480.22 (DOE 1992b), 5480.23 (DOE 1992a), 5483.1A (DOE 1983), 5632.1C (DOE 1994a), 5633.3B (DOE 1994d), 5820.2A (DOE 1988c), P 450.1 (DOE 1995h), 10 CFR 830.120; and 10 CFR 835.

- Storage activities will include container handling required for stabilization of materials to the specifications in DOE-STD-3013-96, Criteria for Safe Storage of Plutonium Metals and Oxides (DOE 1996i).

- Implement and complete stabilization, packaging, immobilization and/or other $\mathrm{Pu}$ disposition activities consistent with HNF-EP-0853, DNFSB Recommendation 94-1 Hanford Site Integrated Stabilization Management Plan (McCormack 1997).

- For stabilization considerations, Pu-bearing material has been grouped into three categories: (1) solutions, (2) residues and mixed oxides ( $<50 \mathrm{wt} \% \mathrm{Pu})$, and (3) metals and oxides $(>50 \mathrm{wt} \% \mathrm{Pu})$.

- Three main process paths are planned for these materials.

- Solutions will undergo stabilization using direct denitration calcination (i.e., vertical calciner) with ion-exchange pretreatment required for two-thirds of the solutions.

- Most residues and oxides $<50 \mathrm{wt} \% \mathrm{Pu}$ and $\mathrm{U}$ will be pretreated as necessary, cemented, and sent to WIPP for disposal. Polycubes will undergo stabilization using the pyrolysis method.

- For metals and oxides $>50 \mathrm{wt} \% \mathrm{Pu}$ and $\mathrm{U}$, materials will be stabilized and repackaged in accordance with DOE-STD-3013 criteria. The Hanford Site will receive an operational Stabilization and Packaging system from BNFL. The Stabilization and Packaging System will complete the stabilization and repackaging in accordance with the PFP baseline schedule. For metals and 
oxides containing impurities that render them incompatible with the Stabilization and Packaging System, stabilization will occur in the muffle furnaces followed by repackaging in the Stabilization and Packaging System. All metals and some alloys will be oxidized before packaging in accordance with DOE-STD-3013 criteria.

\subsection{Material and Waste Flow Requirements/Assumptions.}

\section{Requirements:}

- None.

\section{Planning Assumptions:}

- The following Pu material types remaining at the PFP to be stabilized and/or otherwise dispositioned AFTER FY 1998 are liquids (326 kg Pu); residues, including 1,600 polycubes and mixed oxides $(622 \mathrm{~kg} \mathrm{Pu})$; metal $(736 \mathrm{~kg} \mathrm{Pu})$; oxides $(1,879 \mathrm{~kg}$ $\mathrm{Pu}$ ); and HEU (18 $\mathrm{kg} \mathrm{U})$. This starting inventory is based on prior years (as of March 1996, $26 \mathrm{~kg}$ Pu total had been stabilized and/or cemented). As of February 1997, $422 \mathrm{~kg}$ Pu of unirradiated fuel pins and assemblies are at the PFP in disposition-ready storage. This quantity of pins and assemblies fuel will remain constant until a decision is reached on the future of FFTF. Current planning calls for HEU to be shipped to the Oak Ridge National Laboratory.

4.2.4.7.4 Facility Life-Cycle Requirements/Assumptions. A facility assignment matrix showing facility ownership assignment for life-cycle phases is shown in the following table. The life-cycle phases are those identified in DOE Order 430.1, Life-Cycle Asset Management (DOE 1995c).

\begin{tabular}{|c|c|c|c|c|c|c|c|c|c|}
\hline \multirow{3}{*}{ Complex/facility } & \multicolumn{9}{|c|}{ Life cycle } \\
\hline & \multirow{2}{*}{$\begin{array}{l}\text { Program } \\
\text { planning }\end{array}$} & \multirow[b]{2}{*}{ Preconceptual } & \multirow[b]{2}{*}{ Conceptual } & \multicolumn{3}{|c|}{ Execute } & \multirow{2}{*}{$\begin{array}{l}\text { Ops and } \\
\text { maint }\end{array}$} & \multicolumn{2}{|c|}{ Close out } \\
\hline & & & & Design & Construct & Turnover & & $\begin{array}{c}\text { Post- } \\
\text { operation }\end{array}$ & $D \& D$ \\
\hline \begin{tabular}{|l|} 
Plutonium \\
Finishing Plant
\end{tabular} & RL-TP07 & $\cdots$ & -- & $\cdots$ & $\cdots$ & $\cdots$ & $\begin{array}{l}\text { RL-TP05 } \\
\text { RL-TP06 } \\
\text { RL-TP07 }\end{array}$ & $\begin{array}{l}\text { RL-TP07 } \\
\text { RL-ER05 } \\
\text { RL-TP05 } \\
\text { RL-TP06 }\end{array}$ & $\begin{array}{l}\text { RL-ER06 } \\
\text { RL-ER07 }\end{array}$ \\
\hline
\end{tabular}

$\mathrm{D} \& \mathrm{D}=$ decontamination and decommissioning

\subsection{Other Requirements and Planning Assumptions.}

\section{Requirements:}

- None. 
Planning Assumptions: Key programmatic assumptions are as follows.

- The PFP Laboratory capability is restricted solely to the support of PFP programmatic activities.

- No related upgrades to PFP dangerous waste tanks systems will be required beyond those already planned.

- Any radioactive liquid wastes generated in support of programmatic activities are discharged through the 241-Z Waste Treatment Facility to the 200 West Area tank farms.

- Any nonradioactive or very low-level liquid wastes generated in support of programmatic activities are discharged through the 243-Z Low-Level Treatment Waste Treatment facility to the approved TEDF.

- Very small quantities of radiological contaminated exhaust effluents are released from PFP stacks at levels consistent with the Site's approved gaseous release limits.

- Solid waste at the PFP is classified as nonregulated hazardous, low-level radioactive, TRU radioactive, and mixed (hazardous with radioactive constituents such as LLW and TRU).

- Any solid wastes generated in support of programmatic activities at the PFP are disposed to either the approved Central Waste Storage Complex or the approved TRUSAF. Nonregulated solid waste will be sent to a landfill.

- All Pu at the PFP shall be stabilized and packaged for safe storage in accordance with HNF-EP-0853, DNFSB Recommendation 94-1 Hanford Site Integrated Stabilization Management Plan (McCormack 1997).

- Operations on sludge stabilization and immobilization, in connection with terminal cleanout, will continue until the end of the program in 2014.

- Plutonium materials will be either stabilized, or dispositioned as waste, and packaged/repackaged in accordance with applicable specifications in DOE-STD-3013-96 (DOE 1996i) or the WIPP WAC as appropriate. Plutoniumbearing materials $>50 \mathrm{wt} \% \mathrm{Pu}$ and $\mathrm{U}$ will continue to be stabilized and stored in vaults in accordance with DOE-STD-3013-96 criteria. Plutonium residues $<50 \mathrm{wt} \% \mathrm{Pu}$ and $\mathrm{U}$ will be dispositioned consistent with applicable WIPP WAC and regulations. 
- Facility modifications needed to package and store Pu containers in accordance with DOE-STD-3013-96 are scheduled to be operational by October 2000. Stabilized high-assay material ( $>50 \mathrm{wt} \% \mathrm{Pu}$ and $\mathrm{U})$ will be retrieved from storage and restabilized and packaged consistent with DOE-STD-3013-96 criteria and returned to vault storage. Major vault modifications, necessary to handle the new standardized $\mathrm{Pu}$ storage container, will be required.

- The current laboratory development program will identify and resolve any technology and equipment development issues and will serve as an adequate basis for design of the selected stabilization process systems. The PFP Analytical Laboratory and the Plutonium Process Support Laboratories will be upgraded as required. Additional instrumentation will be provided to support necessary analyses in characterization of miscellaneous solid residues and process support of the stabilization operations.

- Programmatic operations will be on a 24-hour-per-day, 5-day-per-week basis (XYZ schedule) and personnel and funding will be provided to support this level of effort.

- Work scope contained in the New Facility Planning activity data sheet (6625) is now included within this program element.

- The PFP Transition Project end point is anticipated by 2014. This end point is NOT the cessation of all activities as with other Hanford Site facilities. Instead, this end point assumes the continued operation of all SNM shipping, receiving, storage, and vault systems, including all SAS systems plus laboratory capabilities as needed, for an indefinite period. This end point condition is also based on the following.

- Full implementation of DNFSB Recommendation 94-1 is completed in FY 2005 and applicable $\mathrm{Pu}$ vulnerabilities are mitigated.

- Deactivation is initiated in parallel with DNFSB Recommendation 94-1 activities.

- Most of the facility transition to deactivation occurs during FY 2002 through FY 2014.

4.2.4.7.6 Interfaces. PFP Stabilization interfaces with PFP Deactivation through resource, management, and engineering function sharing.

PFP Stabilization interfaces with PFP Vault Management. PFP Vault Management provides Operations Minimum Safe tasks necessary to support PFP Stabilization.

\begin{tabular}{|l|c|l|}
\hline \multicolumn{1}{|c|}{ Project title } & Project number & \multicolumn{1}{|c|}{ Interface } \\
\hline $\begin{array}{l}\text { Solid Waste Storage \& } \\
\text { Disposal }\end{array}$ & RL-WM03 & For disposition of low-level waste and transuranic waste \\
\hline Liquid Waste Program & RL-WM05 & For disposition of liquid effluents \\
\hline
\end{tabular}




\begin{tabular}{|l|c|l|}
\hline \multicolumn{1}{|c|}{ Project title } & Project number & \multicolumn{1}{c|}{ Interface } \\
\hline Tank Farm Operations & RL-TW03 & For disposition of tank waste through FY 2005 \\
\hline Retrieval & RL-TW04 & For disposition of tank waste after FY 2005 \\
\hline Analytical Services & RL-WM06 & For sample analysis and other laboratory support \\
\hline Landlord & RL-TP13 & $\begin{array}{l}\text { To supply infrastructure support and accept sanitary waste and } \\
\text { other landfill waste materials }\end{array}$ \\
\hline
\end{tabular}

$\mathrm{FY}=$ fiscal year

\subsection{Requirements References.}

- DOE-STD-3013-96, Criteria for Preparing and Packaging Plutonium Metals and Oxides for Long-Term Storage (DOE 1996i)

- WHC-SD-CP-SAR-021, Plutonium Finishing Plant Final Safety Analysis Report (Shapley 1995)

- DOE/EM-0199, Plutonium Vulnerability Management Plan (Attachment B, DNFSB 94-1 Implementation Plan) (DOE 1995i)

- HNF-EP-0853, DNFSB Recommendation 94-01 Hanford Site Integrated Stabilization Management Plan (McCormack 1997)

- WHC-SD-CP-OSR-010, Plutonium Finishing Plant Operational Safety Requirements (Szempruch 1994)

- WHC-SP-1126 Facility Stabilization Project Fiscal Year 1997 Multi-Year Work Plan (MYWP) for WBS 7.1 (Cartmell 1996)

- DOE/EIS-0244F, Plutonium Finishing Plant - Final Environmental Impact Statement (DOE 1996g)

- 96-EAP-179, Plutonium Finishing Plant Stabilization Environmental Impact Statement Record of Decision (DOE 1996h).

4.2.4.7.8 Issues. Based on DOE/EIS-0229, Storage and Disposition of Weapons-Usable Fissile Materials Final Programmatic Environmental Impact Statement (DOE 1996j) and the corresponding ROD, no formal decision has been made on the quantity, if any, of PFP Pu materials $>50 \mathrm{wt} \%$ Pu being converted to mixed oxide fuel and burned in reactors.

DOE standards are in flux. Material Disposition acceptance criteria remain undefined. 
Funding is doubtful for completion of the 94-1 program in a timely fashion. The current projected completion date is July 2005.

International Atomic Energy Agency (IAEA) Safeguards at PFP is limited to SNM in Vault 3. If IAEA Safeguards is applied for all SNM inventories at PFP, a significant cost and schedule impact will result.

\subsubsection{PFP Vault Management.}

4.2.4.8.1 Project Description Summary. The PFP Vault Management Project mission is to provide for the safe, stable, cost-effective, and secure storage for SNM at the PFP Complex and to provide the basic infrastructure with which the PFP Stabilization and Deactivation projects are dependent. Nuclear materials will be stored and safeguarded at the PFP pending discussions on this ultimate disposition. This is assured to be until at least FY 2025; plant infrastructure support will be provided until completion of vault deactivation. The 2736-Z/ZB Buildings will receive, store, and ship SNM and other material forms in support of the overall Hanford Site mission as directed.

The PFP Vault Management Subproject supports the PFP Stabilization Subproject which will use the existing plant systems with some necessary modifications to stabilize and disposition all the $\mathrm{Pu}$-bearing materials, provide appropriate packaging, and place the material in safe and secure vaults for storage.

The PFP Vault Management Subproject includes the plant systems, facilities, and processes that provide the Minimum Safe configuration for the PFP, the plant infrastructure systems and projects, the support for IAEA safeguarding of Vault 3, and SAS systems replacement projects.

In addition to the objectives listed in Section 4.2.4, specific project goals include the following.

- Operate and maintain the PFP vault complex to ensure the safe and secure receipt, shipping, and storage of SNM/NM/NF is implemented. This includes SNM inventories, minor vault modifications, and engineering studies/assessments supporting material storage. Analytical Laboratory capabilities will be maintained to support the temporary storage of SNM.

- Perform necessary maintenance, operation surveillance tasks, environmental compliance tasks, corrective maintenance, procedure maintenance, preventive maintenance, plant-specific support, nuclear process/radiation surveillance, project management, ventilation/power surveillance, environmental compliance, and safety boundary and emergency planning for the safety boundaries for the vault complex and former operation/process areas. 
- Perform SAS direction and oversight activities to ensure safe, secure, and compliant storage of SNM/NM/NF until final disposition of the material is accomplished.

Safeguards and security includes physical security, safeguards accounting and material control, record keeping, studies, evaluations, and assessments.

- Provide for IAEA Safeguards for SNM in Vault 3.

- Ensure basic services are made available to the facility from outside sources and costs assessed on a pro rata basis. This support includes such activities as steam, water, utilities, services, etc. It also includes a proportional share of senior management, generic training, administrative support, administrative and progress reporting, project budget/work scope/schedule baseline control, administrative supplies and equipment, and environmental assessments (e.g., solid waste burials).

- Ensure the PFP Project plant infrastructure systems will be maintained. This includes maintenance of systems or facilities such as steam, water, electrical, fire, vacuum and facility common use items, such as roofs, sidewalks, stairs, parking lots, elevators, etc., necessary to enable programmatic work to continue. This also includes all general upgrades and/or modifications to these infrastructure systems.

- Execute specific programmatic work such as all SNM shipments, vault modifications for compliance to new/revised SAS requirements, pollution prevention waste minimization compliance, S/RIDs compliance, Price-Anderson Amendments Act of 1988 compliance, and DOE Requests implementation.

\subsection{Geographic Requirements/Assumptions.}

\section{Requirements:}

- None.

Planning Activities: The PFP Vault Management Subproject supports achievement of Comprehensive Land Use Plan goals by performing the following activities.

- Provide storage, including surveillance and occasional container handling required for stabilization of materials to the specifications in DOE-STD-3013-96 (DOE 1996i), and shipping and receiving of SNM as directed by the DOE.

- Operate and maintain the following buildings to support the material management, material stabilization, material dispositioning, or deactivation activities. Major former operations buildings currently being used to support the material management and material dispositioning activity are the 234-5Z, 236-Z, 241-Z, 243-Z, 291-Z, 2736-Z, and 2736-ZB Buildings. 
- Technical training support is included which consists of development of training certification packages and performance of training and testing, as required by DOE Orders.

- Perform engineering studies, prepare functional design criteria, manage conceptual design, and provide expense support for plant capital and expense projects necessary to correct identified deficiencies, as required by RCRA, WAC 173-303, DOE SAS, and other authorities having jurisdiction.

- As a material management responsibility, the PFP will continue to store most of the remaining SNM at the Hanford Site in safe, secure vaults within the PFP protected area in accordance with DOE Orders. Operation of storage vaults, shipping/receiving capability, and associated security and support requirements will continue indefinitely until the SNM is dispositioned for disposal or transferred to another onsite or offsite facility.

- Upgrade the existing facility infrastructure to enable the facility to support Pu handling in a cost-effective manner. These upgrades are not fully defined but include replacement of the steam system with electric service, replacement of old ventilation control equipment with more reliable and maintainable systems, and modification of facilities as required to support the general stabilization and deactivation of the PFP Complex.

- Perform modernization of the existing SAS systems to provide maintainable remote inventory and surveillance capabilities, part of the material management responsibility.

- Maintain facility FSAR and safety documentation in accordance with DOE Orders.

- Provide support for all general plant and small plant projects as well as support for the line-item-funded project which is part of DNFSB Recommendation 94-1 consisting of the Stabilization and Packaging System and associated vault modifications. The SAS system modernization is expense-funded replacement-in-kind. The laboratory upgrades are expected to be within the constraints of a general plant project.

- Vault 3 will remain under the safeguards of the IAEA during DNFSB Recommendation 94-1 activities. No more material will be made available for IAEA Safeguards until after all DNFSB Recommendation 94-1 stabilization and packaging activities have been completed in FY 2005.

\subsection{Material and Waste Flow Requirements/Assumptions.}

\section{Requirements:}

- None. 


\section{Planning Assumptions:}

- The following Pu material types remaining at the PFP to be stabilized and/or otherwise dispositioned AFTER FY 1998 are liquids (326 kg Pu); residues, including 1,600 polycubes and mixed oxides $(622 \mathrm{~kg} \mathrm{Pu})$; metal $(736 \mathrm{~kg} \mathrm{Pu})$; oxides $(1,879 \mathrm{~kg}$ $\mathrm{Pu}$ ); and HEU (18 kg U). This starting inventory is based on prior years (as of March 1996, $26 \mathrm{~kg}$ Pu total had been stabilized and/or cemented). As of February $1997,422 \mathrm{~kg}$ Pu of unirradiated fuel pins and assemblies were at the PFP in disposition-ready storage. This quantity of fuel pins and assemblies will remain constant until a decision is reached on the future of FFTF. Current planning calls for HEU to be shipped to the Oak Ridge National Laboratory.

- A total of 3,000 spaces will be available for storage of DOE-STD-3013 containers.

\section{2,4.8.4 Facility Life-Cycle Requirements/Assumptions.}

\section{Requirements:}

- None.

Planning Assumptions: A facility assignment matrix showing facility ownership assignment for life-cycle phases is shown in the following table. The life-cycle phases are those identified in DOE Order 430.1, Life-Cycle Asset Management (DOE 1995c).

\begin{tabular}{|c|c|c|c|c|c|c|c|c|c|}
\hline \multirow{3}{*}{ Complex/facility } & \multicolumn{9}{|c|}{ Life cycle } \\
\hline & \multirow{2}{*}{$\begin{array}{l}\text { Program } \\
\text { planning }\end{array}$} & \multirow[b]{2}{*}{ Preconceptual } & \multirow[b]{2}{*}{ Conceptual } & \multicolumn{3}{|c|}{ Execute } & \multirow{2}{*}{$\begin{array}{l}\text { Ops and } \\
\text { maint }\end{array}$} & \multicolumn{2}{|c|}{ Close out } \\
\hline & & & & Design & Construet & Turnover & & $\begin{array}{c}\text { Post- } \\
\text { operation }\end{array}$ & D\&D \\
\hline $\begin{array}{l}\text { Plutonium Finishing } \\
\text { Plant }\end{array}$ & $\mathrm{RL}-\mathrm{TP} 07$ & -. & -- & -- & $\cdots$ & -- & $\begin{array}{l}\text { RL-TP05 } \\
\text { RL-TP06 } \\
\text { RL-TP07 }\end{array}$ & $\begin{array}{l}\text { RL-TP07 } \\
\text { RL-ER05 } \\
\text { RL-TP05 } \\
\text { RL-TP06 }\end{array}$ & $\begin{array}{l}\text { RL_ER06 } \\
\text { RL_ER07 }\end{array}$ \\
\hline
\end{tabular}

$\mathrm{D} \& \mathrm{D}=$ decontamination and decommissioning

4.2.4.8.5 Other Requirements and Planning Assumptions. It is assumed that the facility will be maintained to the minimum safety-compliant configuration at all times. This will be necessary until the last building at the PFP has been deactivated.

Stored Pu will be transported to the onsite High-Level Waste Immobilization Facility and the remaining PFP Vault buildings will be deactivated in accordance with the PFP baseline schedule after that date.

Storage of SNM within existing PFP secure vault areas will continue throughout the foreseeable future. As permitted by the State of Washington and required by Site support needs, SNM will be consolidated at the PFP to permit the reduction in the number of protected areas throughout the Hanford Site. 
Vault 3 will remain under the safeguards of the IAEA during DNFSB Recommendation 94-1 activities at the PFP. No more vaults or materials will be made available for IAEA Safeguards until after all DNFSB Recommendation 94-1 activities have been completed in FY 2005. Funds for converting additional vaults to IAEA Safeguards are not included.

The PFP Deactivation Subproject end point is targeted for completion in FY 2014. This end point is NOT the cessation of all activities as with other Hanford Site facilities. Instead, this end point assumes the continued operation of all SNM shipping, receiving, storage, and vault systems, including all SAS systems plus laboratory capabilities as needed until at least through 2025. Deactivation of the vaults and associated facilities will commence upon transfer of the materials to the onsite High-Level Waste Immobilization Facility.

There is an activity-based cost estimate to support the costs presented for 1997 to 2003. Cost estimate data for 2003 through subproject completion are not supported by an activity-based cost estimate. Fuel pins and assemblies are shipped as-is. Funding for shipping containers is NOT included.

A variety of dissimilar fuel types are or will be stored at the PFP, including Los Alamos Molten Reactor Experiment fuel and FFTF unirradiated fuel assemblies. The planning basis assumes that these unirradiated fuel assembly inventories will remain at the PFP at least until final disposition is determined through the EIS.

Modifications to receive and store additional FFTF fuel assemblies will be funded from the Nuclear Energy Program. The ART Project will transfer $285.9 \mathrm{~kg}$ of Pu, $860.6 \mathrm{~kg}$ of U, and $0.61 \mathrm{MT}$ of heavy metal as disposition-ready material if and when a decision to terminate the FFTF has been made. The storage casks containing FFTF unirradiated fuel assemblies designated for storage at the PFP will be transported to an outdoor location inside the PFP's protected area for storage on a precast concrete pad. The unirradiated FFTF fuel pins and assemblies at the PFP are considered acceptable as-is for long-term storage and further actions are not envisioned for these materials.

The PFP Vault Management Project will be restricted to the operation, maintenance, safeguarding, and securing of the 2736-Z/ZB vault complex. All NM will have been stabilized or dispositioned and the other PFP facilities will have been deactivated. Support will be provided for the IAEA Safeguards of Vault 3, and any other vaults/materials that may be turned over to the IAEA. Specifically, the scope will be composed of the following activities.

- The PFP vault complex will continue to be operated and maintained to ensure safe and secure receipt, shipping, and storage of SNM/NM/NF are implemented. Activities also include SNM inventories, minor vault modifications, and engineering studies/ assessments supporting material storage. Analytical Laboratory capabilities will be maintained to support the temporary storage of SNM. 
- The safety boundaries for the vault complex will receive required maintenance, operation surveillance tasks, environmental compliance tasks, corrective maintenance, procedure maintenance, preventive maintenance, plant-specific support, nuclear process/radiation surveillance, project management, ventilation/power surveillance, environmental compliance, and safety boundary and emergency planning.

- The SAS direction and oversight activities will continue to ensure safe, secure, and compliant storage of stabilized SNM/NM/NF material is maintained.

- Only basic services support to the $2736-Z / Z B$ vault complex, including such activities as water, utilities, telephone services, etc., which are made available from outside sources, will be provided. This also includes all management, training, administrative support, administrative and progress reporting, project budget/work scope/schedule baseline control, administrative supplies and equipment, and environmental assessments (e.g., solid waste burials).

- Programmatic work such as SNM shipments, vault modifications for compliance to new/revised security/safeguards requirements, pollution prevention waste minimization compliance, S/RWD compliance, Price-Anderson Amendments Act of 1988 compliance, and DOE Requests implementation will continue.

Plutonium storage shall continue in a safe and secure manner pending implementation of a national SNM programmatic EIS ROD regarding final disposition.

Plutonium and HEU shall be managed in accordance with DOE Order 5660.1B, Management of Nuclear Materials (DOE 1994e). Plutonium and HEU SAS shall be in accordance with DOE Orders.

Highly enriched uranium shall continue to be stored at the PFP until shipped offsite to Oak Ridge, Tennessee.

4.2.4.8.6 Interfaces. PFP Vault Management interfaces with PFP Deactivation to provide Operations Minimum Safe tasks necessary to support deactivation.

PFP Vault Management interfaces with PFP Stabilization to provide Operations Minimum Safe tasks necessary to support stabilization.

\begin{tabular}{|l|c|l|}
\hline \multicolumn{1}{|c|}{ Project title } & Project number & \multicolumn{1}{|c|}{ Interface } \\
\hline $\begin{array}{l}\text { Solid Waste Storage \& } \\
\text { Disposal }\end{array}$ & RL-WM03 & For disposition of LLW and TRU waste \\
\hline Liquid Waste Program & RL-WM05 & For disposition of liquid effluents \\
\hline Analytical Services & RL-WM06 & For sample analysis and other laboratory support. \\
\hline
\end{tabular}


DOE/RL-97-55

Revision 0

\begin{tabular}{|l|c|l|}
\hline \multicolumn{1}{|c|}{ Project title } & Project number & \multicolumn{1}{c|}{ Interface } \\
\hline Landlord & RL-TP13 & $\begin{array}{l}\text { To supply infrastructure support and accept sanitary waste and } \\
\text { other landfill waste materials }\end{array}$ \\
\hline HAMMER & RL-HM01 & For personnel training support \\
\hline Other DOE sites & -- & For the continued receipt of spent nuclear material \\
\hline SNF Project & RL-WM01 & By storing fuel \\
\hline
\end{tabular}

DOE = U.S. Department of Energy

HAMMER = Hazardous Materials Management and Emergency Response

LLW $\quad=$ low-level waste

SNF = spent nuclear fuel

TRU = transuranic

PFP Vault Management will eventually interface with the Management and Economic Transition Division to seek beneficial uses for excess materials, equipment, and facilities.

PFP Vault Management will eventually interface with Project RL-ER05, S\&M, to transfer deactivated facilities ready for long-term S\&M and/or D\&D.

\subsection{Requirements References.}

- WHC-SP-1126, Facility Stabilization Project Fiscal Year 1997 Multi-Year Work Plan (MYWP) for WBS 7.1 (Cartmell 1996)

- WHC-SD-CP-SAR-021, Plutonium Finishing Plant Final Safety Analysis Report (Shapley 1995)

- WHC-SD-CP-OSR-010, Plutonium Finishing Plant Operational Safety Requirements (Szempruch 1994)

- DOE-STD-3013-96, Criteria for Preparing and Packaging Plutonium Metals and Oxides for Long-Term Storage (DOE 1996i).

4.2.4.8.8 Issues. The final disposition of weapons useable and fuels grade $\mathrm{Pu}$ is unknown. However, NEPA documentation is being developed to further define disposition options.

Isotopes that do not contain $\mathrm{Pu}$ do not have a path forward defined.

Material Disposition acceptance criteria are undefined.

Upgrades necessary to enable the PFP to support Pu handling in a cost-effective manner are not fully defined. 
The Safeguards termination limit is $2 \mathrm{wt} \% \mathrm{Pu}$ in concrete. There is no discard limit.

\subsubsection{324/327 Facility Transition Project.}

4.2.4.9.1 Project Description Summary. The 324/327 Facility Transition Project covers the planning and deactivation and minimum safe activities within the 324 and 327 Buildings. These buildings will be placed in a safe, low-cost, stable condition consistent with ongoing operations. The 324 and 327 Buildings are performing selected stabilization activities in response to Tri-Party Agreement milestones (B-Cell Cleanout and the High-Level Vault tank closures) and to the vulnerability assessments (Cs capsule removal and legacy fuel removal).

The mission of the 324/327 Facility Transition Project is to place these buildings in the lowest radiological classification possible for $S \& M$ pending re-use where feasible or final $D \& D$. This project will remove and/or reduce human health and environmental hazards associated with the 324 and 327 Buildings.

The scope of the 324/327 Facility Transition Project includes minimum safe S\&M, ongoing deactivation/risk mitigation subprojects, and future deactivation subprojects. These subprojects are detailed as follows.

324/327 Minimum Safe Status: Maintain minimum safe activities necessary to protect the public, workers, and environment from exposure posed by loss of containment and control over NM and industrial hazards associated with these buildings.

B-Cell Cleanout Subproject: The B-Cell Cleanout Subproject will eliminate legacy equipment and disposable NM from the B-Cell in the 324 Building. This subproject includes the S\&M of in-cell equipment and filters not included as part of but directly related to B-Cell. The B-Cell Cleanout Subproject also provides for the planning and execution of activities necessary to meet Tri-Party Agreement Milestone M-89-02, "Complete Removal of 324 Building REC B-Cell Mixed Waste and Equipment." Actions under this milestone include containment and removal of all B-Cell dispersible materials, excess equipment, and debris.

CsCl Legacy Safety/Cleanout Subproject: This subproject ensures safe, secure storage of ${ }^{137} \mathrm{Cs}$ in the Hanford Site 300 Area before permanent storage and/or disposal. In addition, this subproject prepares the $\mathrm{CsCl}$ for removal from the 300 Area. The $\mathrm{CsCl}$ inventory includes capsules, pellets, and powder that were generated by several DOE programs. This subproject includes establishment of WESF criteria for Type W overpacks, testing of the overpacks, installation of the overpacks on capsules, and shipment of the Type W overpacks to WESF. Other work includes the decontamination of the 324 Building South Cell to allow personnel entry to replace filters and perform preventive maintenance on the crane, the disposition of the powder and pellets, and the final decontamination and cleanout of the South Cell.

Legacy Fuel Removal Subproject (327): This subproject relates to liquid metal reactor fuel only (the SNF Project will remove all N Reactor fuel and associated equipment/waste). This subproject includes consolidation and disposal of legacy fuel and materials at the facility. The subproject will package fuel, fuel segments and pins, and related material; characterize the existing 
and resultant waste material; and prepare the containers for transport to the 200 Area CWC for interim storage.

High-Heat Source Removal Subproject: This subproject is funded by the Federal Republic of Germany and prepares, packages, and transports vitrified high-heat sources (logs) to a new interim storage pad constructed as part of this project. The Federal Republic of Germany is also providing a compliant shipping cask for the transport of these logs to the new interim storage pad. The vitrified high heat sources were made in the 1980's for the Federal Republic of Germany to support geologic repository development.

In addition to the objectives listed in Section 4.2.4, the 324/327 System and Facilities Deactivation Project objectives include the following:

- Deactivate the 324 and 327 Buildings and transfer to ER in accordance with the integrated baseline schedule.

- Establish plant configurations that require no active systems for safety and environmental confinement.

- Designate the 324 and 327 Buildings to radiological building status upon completion of deactivation using the requirements and standards in DOE-STD-1027-92 (DOE 1992e)

- Complete closure activities for the radiological engineering cells and the high-level vault as the preferred option to meet current Tri-Party Agreement milestone commitments.

- Reduce the annual S\&M costs for both buildings to less than $\$ 250,000$ after deactivation.

\subsection{Geographic Requirements/Assumptions.}

\section{Requirements:}

- None.

Planning Assumptions: The 324/327 Facility Transition Project supports the Comprehensive Land Use Plan goals by performing the following activities.

- 324/327 Minimum Safe Status will be maintained throughout deactivation.

- The B-Cell Cleanout Subproject will remove heavily contaminated process racks (1A Rack, 2A Rack, 1B Rack) via several destructive techniques including plasma arc torches, abrasive cutting blades, reciprocal saws, and cutting shears. Size-reduced equipment will be placed in liners that are grouted before shipment to the CWC as Category III LLW. Beneath these racks are more than 1.5 million curies of dispersible 
radioactive material. These dispersibles and process-contaminated equipment will be packaged and dispositioned to the PUREX tunnels. In addition, seven fuel assemblies will be packaged and shipped to the 400 Area Interim Storage Pad for storage.

- The $\mathrm{CsCl}$ Legacy Safety/Cleanout Subproject will disposition capsules in the 327 Building basins and Cs material within the 324 hot cells. The capsules will be removed from basin storage, and transferred to the 324 Shielded Material Facility in a BUSS cask where the capsule overpacks (known as Type "S") will be removed and replaced with Type "W" overpacks, meeting the acceptance criteria for the WESF pool storage. The newly overpacked capsules will be loaded into BUSS casks for shipment to WESF.

- The High-Heat Source Removal Subproject prepared A-Cell equipment (crane and handling equipment) for transfer of material into seven shipping casks. These casks were loaded and transported to a storage pad within the CWC boundary. Handling equipment will be removed and packaged for disposal and the A-Cell will be prepared for deactivation.

- The Legacy Fuel Removal Subproject (327) will be conducted in two phases. Phase 1 removes, consolidates, packages, and prepares the legacy experimental fuel stored in the Postirradiation Testing Laboratory basin for shipping to the 200 Area CWC. This was completed in 1997. Phase 2 removes, packages, and prepares the RH TRU waste buckets in the building for shipping to the 200 Area CWC.

- The 324/327 System and Facilities Deactivation develops the project management plan (PMP) for the conduct of deactivation projects; completes end point criteria and end point descriptions as required for eventual transfer to the $\mathrm{D} \& \mathrm{D}$ project; and develops and implements deactivation subprojects, which, upon completion, will reduce the risk associated with the 324 and 327 Buildings and limit the ongoing S\&M costs required before final disposition. The PMP was issued in March 1998 (Millikin 1998).

\subsection{Material and Waste Flow Requirements/Assumptions.}

\section{Requirements:}

- None.

\section{Planning Assumptions:}

- During 25 years of research and development activities, B-Cell has accumulated a significant volume of radioactive and radioactive mixed waste. This waste contains more than 2.5 million curies, of which 1.5 million are in a potentially dispersible form.

- Originally, approximately 1.5 million curies of ${ }^{137} \mathrm{Cs}$ existed in the 300 Area inventory. The material inventory and the program generating the legacy material are detailed as follows: 1 non-swollen WESF capsule (i.e., a capsule in which the inner capsule 
moves freely, as determined by the inner capsule movement test, and the outer capsule diameter has not increased to more than $6.9 \mathrm{~cm}$ ). This capsule was used as a gamma source for experiments performed in the 324 Building D-Cell; approximately $5.5 \mathrm{~kg}$ of $\mathrm{CsCl}$ from two opened WESF capsules (Destructive Examination Program); approximately $1.8 \mathrm{~kg}$ of $\mathrm{CsCl}$ powder in $\mathrm{T}-4$ cans from the Oak Ridge National Laboratory (Encapsulation Program); approximately $340 \mathrm{~g}$ of pellets fabricated in a separate program for use in a commercial irradiator facility; 11 swollen WESF capsules (Radiation Sterilizers Incorporated irradiators); and 1 WESF capsule, which is singly encapsulated (Radiation Sterilizers Incorporated irradiators). Transfer to WESF was partially completed in 1997.

- Thirty vitrified high-heat source logs are stored in a water-jacketed (dry) cooling system in the 324 radiochemical A-Cell. These logs, containing an estimated 8.5 million curies, were transferred to CWC in 1997.

- The 327 Building currently contains approximately $252 \mathrm{~kg}$ of fuel and fuel-like material (10 kg of FFTF/Pacific Nuclear Corporation, $45 \mathrm{~kg}$ of Experimental Breeder Reactor-II [both included in this project], and $233 \mathrm{~kg}$ of $\mathrm{N}$ Reactor and $4 \mathrm{~kg}$ of non-liquid metal reactor program fuel). Some of this fuel is containerized in stainless steel containers and stored in water-filled basins within the building structure. The 327 Building is continuing programmatic fuels examination work for SNF and fuels examination for other entities as approved by the DOE.

\subsection{Facility Life-Cycle Requirements/Assumptions.}

\section{Requirements:}

- None.

Planning Assumptions: A facility assignment matrix showing facility ownership assignment for life-cycle phases is shown in the following table. The life-cycle phases are those identified in DOE Order 430.1, Life-Cycle Asset Management (DOE 1995c).

\begin{tabular}{|c|c|c|c|c|c|c|c|c|c|}
\hline \multirow{3}{*}{ Complex/facility } & \multicolumn{9}{|c|}{ Life cycle } \\
\hline & \multirow{2}{*}{$\begin{array}{l}\text { Program } \\
\text { planning }\end{array}$} & \multirow[b]{2}{*}{ Preconceptual } & \multirow[b]{2}{*}{ Conceptual } & \multicolumn{3}{|c|}{ Execute } & \multirow[b]{2}{*}{$\begin{array}{c}\text { Ops and } \\
\text { maint }\end{array}$} & \multicolumn{2}{|c|}{ Close out } \\
\hline & & & & Design & Construct & Tumover & & $\begin{array}{c}\text { Post- } \\
\text { operation }\end{array}$ & $D \& D$ \\
\hline $\begin{array}{l}\text { 324/327 Facility } \\
\text { Transition Project }\end{array}$ & RL-TP08 & -. & -- & -- & $\cdots$ & -. & $\begin{array}{l}\text { RL-TP08 } \\
\text { RL-ST01 }\end{array}$ & $\begin{array}{l}\text { RL-TP08 } \\
\text { RL-ER05 }\end{array}$ & $\begin{array}{l}\text { RL-ER06 } \\
\text { RL-ER07 }\end{array}$ \\
\hline
\end{tabular}

$\mathrm{D} \& \mathrm{D}=$ decontamination and decommissioning

4.2.4.9.5 Project Safety Authorization Basis. The current safety authorization basis for the 324 Buildings is contained in PNL-SAR-324, 324 Building Safety Analysis Report (PNL 1995a). The safety authorization basis for the 327 Buildings is contained in PNL-SAR-327, 327 Building Safety Analysis Report (PNL 1995b).

These buildings shall be operated in accordance with 324 and 327 Operations manuals. 
Environmental, safety, and health requirements for the 324 and 327 Buildings are contained in the S/RID for 324 and 327.

4.2.4.9.6 Other Requirements and Planning Assumptions. Nuclear material currently designated as RH TRU will remain RH TRU. Nuclear material currently managed as SNF will remain SNF.

Significant changes to draft end points will cause changes to cost, work scope, and schedule.

The PUREX tunnel or CWC will be able to accept RH TRU from the B-Cell Cleanout Subproject (special waste). The WESF will accept the overpacked Cs capsules and repackaged Cs powder and pellets.

\subsection{Interfaces.}

\begin{tabular}{|c|c|c|}
\hline Project title & Project number & Interface \\
\hline $\begin{array}{l}\text { Solid Waste Storage \& } \\
\text { Disposal }\end{array}$ & RL-WM03 & For disposition of $L L W$ and TRU waste \\
\hline Liquid Waste Program & RL-WM05 & For disposition of liquid effluents \\
\hline Tank Farm Operations & RL-TW03 & For disposition of tank waste \\
\hline $\begin{array}{l}\text { Pacific Northwest Waste } \\
\text { Management }\end{array}$ & RL-ST01 & For nonradioactive waste traceability studies \\
\hline Analytical Services & RL-WM06 & For sample analysis and other laboratory support \\
\hline $\begin{array}{l}\text { Management and Economic } \\
\text { Transition Division }\end{array}$ & -- & $\begin{array}{l}\text { To seek beneficial uses for excess materials, equipment, and } \\
\text { facilities }\end{array}$ \\
\hline Landlord & RL-TP13 & $\begin{array}{l}\text { To supply infrastructure support and accept sanitary waste and } \\
\text { other landfill waste materials }\end{array}$ \\
\hline HAMMER & RL-HMO1 & For personnel training support \\
\hline WESF & RL-TP02 & $\begin{array}{l}\text { To transfer } 13 \mathrm{Cs} \text { capsules and repackaged Cs powder and } \\
\text { pellets and } 3 \text { failed capsules }\end{array}$ \\
\hline SNF Project & RL-WMO1 & $\begin{array}{l}\text { Conducting examination and performing characterization } \\
\text { activities in support of SNF Project }\end{array}$ \\
\hline $\begin{array}{l}\text { Advanced Reactors } \\
\text { Transition }\end{array}$ & RL-TP11 & For FFTF fuel and 400 Area ISA operations \\
\hline$S \& M$ & RL-EROS & $\begin{array}{l}\text { To transfer deactivated facilities ready for long-term } S \& M \text { and/or } \\
\text { D\&D }\end{array}$ \\
\hline
\end{tabular}


DOE/RL-97-55

Revision 0

May 28, 1998

\begin{tabular}{|l|l|l|}
\hline Project title & Project number & Interface \\
\hline D\&D & = decontamination and decommissioning \\
FFTF & $=$ Fast Flux Test Facility \\
HAMMER & $=$ Hazardous Materials Management and Emergency Response \\
ISA & = Interim Storage Area \\
LLW & = low-level waste \\
Pacific Northwest & $=$ Pacific Northwest National Laboratory \\
S\&M & = surveillance and maintenance \\
SNF & = spent nuclear fuel \\
TRU & = transuranic \\
WESF & = Waste Encapsulation and Storage Facility
\end{tabular}

\subsection{Requirements References.}

- PNL-SAR-327, 327 Building Safety Analysis Report (PNL 1995b)

- PNL-SAR-324, 324 Building Safety Analysis Report (PNL 1995a)

- Tri-Party Agreement Milestone M-89-02, "Complete Removal of 324 Building B-Cell Mixed Waste and Equipment"

- Plan of Action to Resolve Spent Nuclear Fuel Vulnerabilities Phase I (DOE 1994f).

4.2.4.9.9 Issues. Delays in approval of the path forward for the 327 Building legacy fuel removal (storage and disposal location) are jeopardizing milestone completion.

There is currently no identified storage and disposal location for the B Cell dispersible wastes (special waste).

The light-water reactor fuel assemblies in the 324 Building REC cells currently are under an MOU identifying storage at the 400 Area ISA. Continued development and procurement of the Nuclear Assurance Corporation casks for storage at the 400 Area ISA have been canceled.

\subsubsection{Accelerated Deactivation Project.}

4.2.4.10.1 Project Description Summary. The purpose of this project is to deactivate all Hanford Site contaminated facilities outside the 300 Area that are not currently being deactivated or scheduled for deactivation under another PBS. Initially, those facilities that no longer have a current mission and those expected to no longer have a viable mission after FY 2000 will be deactivated. All other included radiologically and hazardous contaminated facilities expected to have viable missions after FY 2000 will be deactivated upon their mission completion (which could extend 20 years or more into the future).

There are 32 non-mobile contaminated facilities that are assumed to either currently no longer have a viable mission or are expected to no longer have viable missions after FY 2000. Four facilities were transferred into the PBS in FY 1997 (222T, 222U, 231-Z, and 2704C). Four 
more are expected in FY 1998 or FY 1999 (242B, 242BL, 2718, and 209E). The remaining 24 $(1208,1226,1227,1253,1517 \mathrm{~N}, 151 \mathrm{~B}, 1720 \mathrm{DR}, 2711 \mathrm{E}, 2711 \mathrm{EA}, 2713 \mathrm{~W}, 2715 \mathrm{E}, 2715 \mathrm{EA}$, 2715EC, 2715ED, 2715M, 6652H, 275UR, 4722C, 6291, 212P, 748, 224T, 242S, and 242T) are expected to be transferred between FY 2000 and FY 2010. Another 16 non-mobile contaminated buildings (242A, 200TEDF, 200LERF, 200ETF, RHT and Large Equipment Facility, SW Retrieval Facility, WRAP 1, and 222S facilities) have viable missions beyond FY 2010. These facilities will be transferred between FY 2014 and FY 2035 as their missions end.

Most of the facilities covered in this PBS are not close to the Columbia River or other areas occupied by the public. However, the facilities are contaminated with both radiological and hazardous materials. Contaminants of concern include $\mathrm{Cs}, \mathrm{Sr}, \mathrm{U}$, mixed fission products, fuels processing and chemical contamination that includes various acids and bases, and a variety of cleaning agents and solvents. Many of these facilities have also exceeded their design life. A fire, containment system failure, or structural collapse due to natural causes or facility deterioration could result in a release of contaminants to the environment via air, ground, and water pathways overexposing onsite workers. Most areas outside these facilities already contain radiological and hazardous contaminants in the soil and an additional release of contaminants would further complicate and increase the scope and risks of future remediation efforts. Deactivation of these facilities reduces risk to the public, environment, and onsite workers by removing and/or stabilizing radiological and hazardous contamination and placing these high-risk facilities in a low risk "caretaker" status until they can be demolished.

The mission of the Accelerated Deactivation Project is to place these facilities in the lowest radiological classification possible for $S \& M$ pending final $D \& D$.

Accelerated Deactivation Project objectives are listed in Section 4.2.4.

\subsection{Geographic Requirements/Assumptions.}

\section{Requirements:}

- None.

Planning Assumptions: The Accelerated Deactivation Project will support Comprehensive Land Use Plan goals by performing the following activities.

- Initially, a strategic plan for these facilities will be developed. The current missions for facilities will be examined. Facility assessments will be performed initially on those that no longer have viable missions to provide information to determine the relative risk of each facility and develop a scope of work to deactivate each facility. Specific facility end points will be developed and a prioritization of the facilities will be performed based on risk reduction, mortgage reduction, and maximization of cleanup progress. A schedule showing the sequence of buildings and necessary funding will be 
developed and captured in a project management plan. Regulatory documentation will be prepared as necessary. The project management plan will be updated annually to include facilities as their missions are completed.

- The project will use a phased approach to perform physical work by using small, specialized work groups in combination with a few people having specific building knowledge. Teams specialized in building evaluation, relocation of people and equipment, contamination removal and fixation, and facility deactivation will be formed. The buildings will then be put through these various stages sequentially. Facilities are anticipated to be geographically grouped as they go through this process.

\subsection{Material and Waste Flow Requirements/Assumptions.}

\section{Requirements:}

- None.

Planning Assumptions: Material and waste flow projections have not yet been established for this project.

4.2.4.10.4 Facility Life-Cycle Requirements/Assumptions. A facility assignment matrix showing facility ownership assignment for life-cycle phases does not exist, but development is planned to begin this fiscal year.

4.2.4.10.5 Project Safety Authorization Basis. Existing facility safety authorization basis documentation shall be examined before commencement of deactivation activities to ensure a proper safety authorization basis is in place to allow economical, efficient deactivation.

\subsection{Other Requirements and Planning Assumptions.}

\section{Requirements:}

- None.

\section{Planning Assumptions:}

- Because the total scope to deactivate these facilities to a caretaker status has not yet been determined, deactivation end point criteria and project management plans will be developed to establish the project scope, cost, schedules, and more accurate performance measures.

- The cost to perform S\&M of these facilities is assumed to already be included in other programs and will be transferred with the facilities as they enter this project to supplement the deactivation cost. If this is not possible, 3 years notice of transfer will allow the additional S\&M budget to be planned, requested, and approved. In these 
cases, the S\&M funding will be approved before acceptance of the facility into this project.

- Costs to develop alternate, or modify existing SNM/NM/NF storage locations, to treat or otherwise stabilize SNM/NM/NF materials, except as necessary to consolidate and remove them from a given facility, are not included in this project.

- Many of the facilities listed have a continuing mission today. Deactivation of these facilities will not begin until their missions are completed. Upon completion of deactivation, it is assumed that a facility can be turned over to EM-40 within a 2-year period. As facilities are deactivated, they will be turned over to EM-40 for D\&D in groups, the groups consisting of facilities within the same geographic area (facilities within such a group may have belonged to more than one program before the start of deactivation).

- This project will not include deactivation of proposed facilities, those currently in construction, or those planned to be "privatized."

- T Plant and associated facilities are not included in this project.

\subsection{Interfaces.}

\begin{tabular}{|c|c|c|}
\hline Project title & Project number & Interface \\
\hline Tank Farm Operations & RL-TW03 & $\begin{array}{l}\text { To facilitate turnover of contaminated excess facilities for } \\
\text { deactivation to either new future uses or D\&D }\end{array}$ \\
\hline $\begin{array}{l}\text { Science and Technology } \\
\text { Project }\end{array}$ & $\begin{array}{l}\text { RL-ST01 and } \\
\text { OT-03 }\end{array}$ & $\begin{array}{l}\text { To facilitate turnover of contaminated excess facilities for } \\
\text { deactivation to either new future uses or D\&D }\end{array}$ \\
\hline Landlord & RL-TP13 & $\begin{array}{l}\text { To facilitate turnover of contaminated excess facilities for } \\
\text { deactivation to either new future uses or } D \& D\end{array}$ \\
\hline Solid Waste & RL-WM04 & $\begin{array}{l}\text { To facilitate turnover of contaminated excess facilities for } \\
\text { deactivation to either new future uses or D\&D }\end{array}$ \\
\hline Liquid Waste & RL-WMOS & $\begin{array}{l}\text { To facilitate turnover of contaminated excess facilities for } \\
\text { deactivation to either new future uses or D\&D; for disposition of } \\
\text { liquid effluents }\end{array}$ \\
\hline Analytical Services & RL.WM06 & $\begin{array}{l}\text { To facilitate turnover of contaminated excess facilities for } \\
\text { deactivation to either new future uses or D\&D; for sample } \\
\text { analysis and other laboratory support }\end{array}$ \\
\hline $\begin{array}{l}\text { Solid Waste Storage \& } \\
\text { Disposal }\end{array}$ & RL-WM03 & For disposition of LLW and TRU waste \\
\hline Tank Farm Operations & RL-TW03 & For disposition of tank waste through FY 2005 \\
\hline Retrieval & RL-TW04 & For disposition of tank waste after FY 2005 \\
\hline
\end{tabular}


DOE/RL-97-55

Revision 0

May 28, 1998

\begin{tabular}{|l|c|l|}
\hline \multicolumn{1}{|c|}{ Project title } & Project number & \multicolumn{1}{c|}{ Interface } \\
\hline $\begin{array}{l}\text { Management and Economic } \\
\text { Transition Division }\end{array}$ & -- & $\begin{array}{l}\text { Seek beneficial uses for excess materials, equipment, and } \\
\text { facilities }\end{array}$ \\
\hline Landlord & RL-TP13 & $\begin{array}{l}\text { To supply infrastructure support and accept sanitary waste and } \\
\text { other landfill waste materials }\end{array}$ \\
\hline HAMMER & RL-HM01 & For personnel training support \\
\hline S\&M & RL-ER05 & $\begin{array}{l}\text { To transfer deactivated facilities ready for long-term } \text { S\&M and/or } \\
\text { D\&D }\end{array}$ \\
\hline
\end{tabular}

D\&D = decontamination and decommissioning

$\mathrm{FY} \quad=$ fiscal year

HAMMER = Hazardous Materials Management and Emergency Response

LLW $\quad=$ low-level waste

S\&M = surveillance and maintenance

TRU = transuranic

4.2.4.10.8 Logic Diagram. The overall approach to deactivation of these facilities will be outlined in deactivation plans. Logical relationships between project activities will be contained in the project schedules.

4.2.4.10.9 Requirements References. Requirements will be identified when plans are developed.

4.2.4.10.10 Issues. Excess facilities exist that are not being deactivated.

\subsubsection{300 Area Disposition Project.}

4.2.4.11.1 Project Description Summary. Because of the Hanford Site mission change from defense production to cleanup and downsizing, the 300 Area has several excess facilities requiring disposition beyond simple removal. These facilities include a reactor building, an accelerator building, and many buildings used for reactor fuel production and processing activities. Most of the facilities contain significant radiological and chemical contamination, with eight facilities currently managed under RCRA. The 300 Area contains multiple burial grounds and liquid disposal and spill sites, which are managed under CERCLA as three separate operable units. There are 156 non-mobile facilities listed in the 300 Area. Of these, 46 facilities contain radioactive, and 11 contain hazardous, contamination. The remaining 99 buildings are not listed as contaminated, but further verification of that condition is warranted on some of them because known historical uses and contamination of nearby grounds make them suspect. Eighteen contaminated buildings are being deactivated (300 Fuel Supply, 308 Building, 309 Building) and five more contaminated facilities are scheduled to begin deactivation in 1997 (324, 324A, 324D, 327 , and 3723 Buildings) and are not included in the scope of this PBS.

A draft 300 Area mission analysis was developed in FY 1997 to examine current and future 300 Area missions and discuss possible end states for the 300 Area. A draft 300 Area decision document was also developed in FY 1997 to analyze at a high level, the merits and 
feasibility of achieving various interim and final states for the 300 Area. The conclusion of this document supports workshop discussions and recommends that the 300 Area be transitioned to an interim state in the near term.

Transition of the 300 Area to an interim state in the near term means many clean and contaminated facilities will no longer be needed and should be demolished. It also means that some clean and contaminated facilities will continue to serve existing and future missions. The purpose of this project is to deactivate excess contaminated facilities and refurbish those contaminated facilities that are expected to be needed to support the national research and development mission or that will promote economic diversification. This project also provides funding and a support system for the acceptance of 300 Area contaminated facilities that are declared excess or are anticipated to be declared excess in the future. This scope is only part of the scope necessary to transition the 300 Area to an interim state.

The demolition of excess clean facilities along with refurbishment of any clean facilities is within the EM-70 scope and has been assigned to it. The demolition of excess contaminated facilities is within the EM-40 scope and has been assigned to it. The deactivation of excess contaminated facilities, along with refurbishment of any contaminated facilities, is within the scope of this PBS.

Facilities most likely to be necessary to support the ongoing national research and development mission or promote economic diversification are in the process of being identified. Once these facilities are identified, the infrastructure necessary to support them can also be determined along with all the facilities that will eventually be excessed.

Most 300 Area contaminated facilities constitute a risk to the public, environment, and onsite workers due to contamination with a variety of materials including $\mathrm{Cs}, \mathrm{Sr}, \mathrm{U}, \mathrm{Th}$, mixed fission products, various acids and bases, and a variety of cleaning agents and solvents. The facilities covered in this project are close to the Columbia River and the city of Richland. With the continual reduction in Hanford Site security taking place, the likelihood of a member of the public entering this area unescorted without the necessary protective clothing and equipment is very high. A fire, containment system failures, or structural collapse due to natural causes or facility deterioration could result in a release of contaminants to the environment via air, groundwater, and water pathways. Many of these facilities have exceeded their design life, and will pose an increasing hazard to Site workers as the facilities continue to deteriorate.

This project reduces risk to the public, onsite workers, and the environment by removing, stabilizing, or isolating contaminants; providing surveillance and maintenance to ensure releases do not occur; keeping facilities in an acceptable material condition or sufficiently isolated to avoid worker hazards due to facility deterioration; and providing a mechanism for final disposition of the facilities. Risk is also reduced by ensuring that contaminated facility deactivation follows a priority-based path, and by having the transition activities performed by experienced personnel. The planning and scheduling process for the transition of these facilities should include assessments of each facility's hazards and associated risk, which are then used in determining where the facility should be placed on the transition schedule. 
In FY 1997, five facilities $(321,321 \mathrm{~B}, 321 \mathrm{D}, 3706,3706 \mathrm{~A})$ were assigned to FSP.

The mission of the 300 Area Disposition Project is as follows.

- Deactivate excess contaminated facilities and refurbish those contaminated facilities that are expected to be needed to support the national research and development mission or will promote economic diversification.

- Provide a system for the acceptance of 300 Area contaminated facilities that are declared excess or are anticipated to be declared excess in the future.

4.2.4.11.2 Geographic Requirements/Assumptions. This project supports Comprehensive Land Use Plan goals by performing the following activities.

- Perform conversion activities, which include those deactivation actions necessary to allow a facility to perform a new mission. Costs connected with equipping a facility to perform a new mission are not included.

- Perform the following final disposition activities: perform S\&M and environmental monitoring; develop regulatory documentation and other project management documentation; perform characterization activities; perform radioactive and hazardous waste treatment and disposition activities; perform decontamination of equipment, surfaces, and structures; assess and expedite alternate use; deactivate facility equipment, systems; and utilities; perform facility walkdowns and necessary surveys and other verification activities; and perform project management.

- The current missions for facilities will be examined. Facility assessments will be performed. Specific facility end points will be developed and a prioritization of the facilities will be performed based on risk reduction, mortgage reduction, and maximization of cleanup progress. A schedule showing the sequence of building deactivation or conversion and necessary funding will be developed and captured in a 300 Area project management plan. Existing regulatory documentation will be reviewed and new documentation prepared as necessary.

- Use a phased approach to perform physical work by using small specialized work groups in combination with a few people having specific building knowledge. Teams specializing in building evaluation, relocation of people and equipment, contamination removal and fixation, facility deactivation, and facility conversion will be formed. The buildings will then be put through these various stages sequentially. Facilities are anticipated to be geographically grouped as they go through this process (306 E and $306 \mathrm{~W}$ together; 340, 340A, 340B together; etc.).

4.2.4.11.3 Material and Waste Flow Requirements/Assumptions. Material and waste flows for this subproject have not yet been developed. 
4.2.4.11.4 Facility Life-Cycle Requirements/Assumptions. A facility assignment matrix showing facility ownership assignment for life-cycle phases does not exist, but development will begin this fiscal year.

4.2.4.11.5 Project Safety Authorization Basis/NEPA and Permits. Existing facility safety Authorization Basis documentation shall be reviewed/revised before work execution to ensure the proper safety Authorization Basis is in place to support economical and efficient project execution.

4.2.4.11.6 Other Requirements and Planning Assumptions. Because the total scope to deactivate or convert these facilities has not yet been determined, deactivation end point criteria and project management plans will be developed to establish the project scope, cost, schedules, and more accurate performance measures.

The Nuclear Energy Legacy Project will complete removal of $\mathrm{Na}$ and associated equipment from 300 Area facilities.

The cost to develop alternate, or modify existing, SNM/NM/NF storage locations outside the 300 Area, to treat or otherwise stabilize SNM/NM/NF materials, except as necessary to consolidate and remove them from the 300 Area, is not included in this project.

Conversion activities include only those deactivation actions necessary to allow a facility to perform a new mission. Equipping a facility to perform a new mission is not included.

\subsection{Interfaces.}

\begin{tabular}{|l|c|l|}
\hline \multicolumn{1}{|c|}{ Project title } & Project number & \multicolumn{1}{|c|}{ Interface } \\
\hline $\begin{array}{l}\text { Science and Technology } \\
\text { Project }\end{array}$ & $\begin{array}{c}\text { RL-ST01 and } \\
\text { TO-03 }\end{array}$ & $\begin{array}{l}\text { To facilitate turnover of excess facilities for conversion, } \\
\text { deactivation, or D\&D }\end{array}$ \\
\hline Landlord & RL-TP13 & $\begin{array}{l}\text { To facilitate turnover of excess facilities for conversion, } \\
\text { deactivation, or D\&D }\end{array}$ \\
\hline Solid Waste & RL-WM0S & $\begin{array}{l}\text { To facilitate turnover of excess facilities for conversion, } \\
\text { deactivation, or D\&D }\end{array}$ \\
\hline Liquid Waste & RL-WM06 & $\begin{array}{l}\text { To facilitation, or D\&D and for disposition of liquid effluents } \\
\text { deactivation, or D\&D and for sample analysis and other } \\
\text { laboratory support }\end{array}$ \\
\hline Analytical Services & RL-WM03 & For disposition of low-level waste and transuranic waste \\
\hline $\begin{array}{l}\text { Solid Waste Storage \& } \\
\text { Disposal }\end{array}$ & RL-TW03 & For disposition of tank waste through fiscal year 2005 \\
\hline TankFarm Operations & RL-TW04 & For disposition of tank waste after fiscal year 2005 \\
\hline Retrieval & $\begin{array}{l}\text { To seek beneficial uses for excess materials, equipment, and } \\
\text { facilities }\end{array}$ \\
\hline $\begin{array}{l}\text { Management and Economic } \\
\text { Transition Division }\end{array}$ & $\begin{array}{l}\text { Indirect, no } \\
\text { project baseline } \\
\text { summary } \\
\text { number }\end{array}$ & $\begin{array}{l}\text { To supply infrastructure support and accept sanitary waste and } \\
\text { other landfill waste materials and to manage D\&D of clean } \\
\text { excess facilities }\end{array}$ \\
\hline Infrastructure & RL-ER05 & To perform D\&D of deactivated excess contaminated facilities \\
\hline
\end{tabular}




\begin{tabular}{|c|c|l|}
\hline Project tifle & Project number & \multicolumn{1}{|c|}{ Interface } \\
\hline HAMMER & RL-HMOI & For personnel training support \\
\hline
\end{tabular}

$\mathrm{D} \& \mathrm{D}=$ decontamination and decommissioning

HAMMER = Hazardous Materials Management and Emergency Response

$\mathrm{S} \& \mathrm{M}=$ surveillance and maintenance

\subsection{Requirements References.}

- Hanford Excess Facility Management Plan, December 1996, Attachment 4, containing risk event scenarios, required field conditions, likelihood of occurrence, and relative risk levels for excess facilities

- WHC-MR-0388, Past Practices Technical Characterization Study - 300 Area Hanford Site (Gerber 1992).

4.2.4.11.9 Issues. This project needs to be coordinated with 300 Fuel Supply Deactivation, 324/327 Facility Transition Project, 340 Deactivation, 309 Building Deactivation, ART Nuclear Energy Legacy activities, EM-70 demolition of clean excess facilities and refurbishment of clean support facilities, ER-7 planned facility upgrades, FDH economic development efforts, and EM-40 D\&D and Operable Unit remediation to deliver a cleaned-up 300 Area "interim" state. 
DOE/RL-97-55

May 29, 1998

Revision 0

\section{Infrastructure}

Concurrence: Original signed by S. T. Burnum Approved by: Orig. signed by T. O. Schmeeckle S. T. Burnum, Site Infrastructure Division, U.S. Department of Energy, Richland Operations Office W. A. Rutherford, Director, Site Infrastructure Division, U.S. Department of Energy, Richland Operations Office 


\subsubsection{Infrastructure Project}

\subsubsection{Landlord Project}

4.2.5.1.1 Project Description Summary. The Landlord Project provides the following:

- Minimum Safe - Essential Core Infrastructure Maintenance--These activities provide the minimal infrastructure necessary for the Site to maintain safe operations and progress toward the cleanup mission. This includes capital equipment procurements, general plant projects, and expense funding necessary to support required activities.

- Minimum Safe - Surveillance, Maintenance, and Deactivation of Vacant GeneralPurpose Facilities--These activities provide funding for $\mathrm{S} \& \mathrm{M}$ of vacant generalpurpose facilities, as well as utility isolation of facilities recently vacated. This also includes activities associated with maintaining RCRA compliance for legacy equipment dispositions.

- Disposition of Uncontaminated, Vacant, General-Purpose Facilities/Mortgage Reduction--These activities provide for demolition of vacant, general-purpose facilities and mortgage reduction opportunities.

\subsection{Geographic Requirements/Assumptions.}

\section{Requirements:}

- Infrastructure will be maintained in a minimum-safe condition to all Site locations where it is essential to accomplish project work. Replacement, rather than continuing repair of systems, will be done only when it is cost-effective (i.e., when life-cycle cost savings can be realized).

\section{Planning Assumptions:}

- Pending Congressional action on the Wild and Scenic River designation, use of the Reactors on the River Area and the Columbia River Area will continue to be restricted. Sensitive ecological, cultural, and Native American resources will be protected.

- The federal government will retain ownership of land in and adjacent to the 300 and 400 Areas, but will lease land for private and public uses to support regional industrial and economic development.

- Excess land within the 1100 Area will be targeted for transition to non-federal ownership.

- The Central Core Area will remain in federal ownership consistent with safety analysis boundaries and waste management operations in the 200 Area. 
- The Central Core Area will be available for other federal programs or leased for non-federal uses, consistent with appropriate recognition of cultural and ecosystem values.

\subsection{Material and Waste Flow Requirements/Assumptions.}

\section{Requirements:}

- The Landlord Project generates a small amount of radioactive waste from disposition of regulated rail cars and equipment.

- The Landlord Project will generate wastes from demolition of vacant, general-purpose facilities beginning in FY 2008. Between 1,232 and $1,800 \mathrm{~m}^{3}$ of solid sanitary waste in the form of building rubble and approximately $36 \mathrm{~m}^{3}$ of asbestos waste from pipe insulation, siding, and floor and ceiling tile will be generated each year.

\section{Planning Assumptions:}

- Demolition of vacant, general-purpose facilities will not be funded in FY 1998 or FY 1999, but will be funded between $\$ 2$ million and $\$ 3$ million per year beginning in FY 2000.

4.2.5.1.4 Facility Life-Cycle Requirements/Assumptions. The following table identifies life-cycle responsibility for major Infrastructure Project facilities. The Hanford Site Technical Baseline Database uses these data to define interfaces between Hanford Site projects. The life-cycle phases are those identified in DOE Order 430.1, Life-Cycle Asset Management (DOE 1995c).

\begin{tabular}{|l|c|c|l|l|}
\hline \multicolumn{1}{|c|}{ Major facility } & $\begin{array}{c}\text { Planning, preconceptual, } \\
\text { and conceptual }\end{array}$ & Execution & \multicolumn{1}{|c|}{ Operations \& maintenance* } & Close out \\
\hline $\begin{array}{l}\text { Electrical } \\
\text { Systems }\end{array}$ & -- & -- & DynCorp Electrical Utilities & RL-TP13 \\
\hline $\begin{array}{l}\text { Raw Water } \\
\text { Systems }\end{array}$ & -- & -- & DynCorp Water Utilities & RL-TP13 \\
\hline $\begin{array}{l}\text { Potable Water } \\
\text { Systems }\end{array}$ & -- & -- & DynCorp Water Utilities & RL-TP13 \\
\hline Steam Systems & -- & -- & DynCorp/Johnson Controls & RL-TP13 \\
\hline $\begin{array}{l}\text { Liquid Sanitary } \\
\text { Waste Systems }\end{array}$ & -- & -- & DynCorp Sanitary Utilities & RL-TP13 \\
\hline $\begin{array}{l}\text { Telecommuni- } \\
\text { cations }\end{array}$ & -- & -- & Lockheed Martin Services, Inc. & RL-TP13 \\
\hline Office Facilities & -- & -- & DynCorp Facility Management & RL-TP13 \\
\hline Shop Facilities & -- & -- & $\begin{array}{l}\text { DynCorp Facility Maintenance and } \\
\text { Site Services }\end{array}$ & RL-TP13 \\
\hline $\begin{array}{l}\text { Storage } \\
\text { Facilities }\end{array}$ & - & -- & DynCorp Asset Management & RL-TP13 \\
\hline Land & -- & -- & RL-TP13 & RL-TP13 \\
\hline
\end{tabular}




\begin{tabular}{|l|c|c|l|l|}
\hline Laboratories & -- & -- & Laboratory Management & RL-TP13 \\
\hline Road System & -- & -- & DynCorp Fleet Operations & RL-TP13 \\
\hline Rail System & -- & -- & DynCorp Rail Operations & RL-TP13 \\
\hline $\begin{array}{l}\text { Sanitary Waste } \\
\text { Landfill }\end{array}$ & -- & -- & Not applicable & RL-TP13 \\
\hline
\end{tabular}

*Indirect - no Project Breakdown Structure number.

\subsection{Key Technical Requirements.}

\section{Requirements:}

- Disposition of legacy contaminated equipment shall comply with RCRA. Ecology currently monitors this activity.

- Demolition of vacant, general-purpose facilities and mortgage reduction are necessary to clean up the Site. The longer this activity is deferred, the more expensive it will be for the Site. The Hanford Excess Facility Management Plan provides the overall guiding documents and priorities of excess facility disposition.

- Regulatory basis for landfill closure: WAC 173-303-460 (3) (e) requires all solid waste landfills to be covered with a liner (soil or artificial) $1 \times 10 \mathrm{E}-5 \mathrm{~cm} / \mathrm{s}$ or lower permeability. A liner is NOT optional and budget planning needs to include this item. WAC 173-304-407 (5) (a) requires a closure plan in part or in whole no later than 180 days after final receipt of waste at the facility. The DOE is out of compliance here, but enforcement will not be taken as long as the DOE is making progress.

- If there is any evidence of leachate or waste constituents detected in the vadose zone that violates, or could be expected to violate, the performance standards in WAC 173-304-460 (2), the operator is required to take corrective action and either close the facility according to WAC 173-304 or install a liner in future expansions (not applicable to solid waste landfills). Performance standards in WAC 173-304-460 (2) state that an "owner or operator of a landfill shall not contaminate the groundwater underlying the landfill, beyond the point of compliance (facility boundary)." Contamination has been detected in the wells at the solid waste landfill boundary; therefore, the corrective action requirements have been triggered. The closure of the solid waste landfill may require corrective actions to be performed and possible postclosure monitoring.

\section{Planning Assumptions:}

- None. 


\subsection{Project Safety Authorization Basis/NEPA and Permits.}

\section{Requirements:}

- The road system shall be maintained in a safe and compliant condition. If rehabilitation of the roads is deferred, deterioration will accelerate. Most of the Site roads have a minimal base $(-7.6 \mathrm{~cm})$, which is well below current road requirements for similar temperature-zoned areas $(\sim 45.7 \mathrm{~cm})$, so preventive measures are a necessity to avoid total replacement. Cracks quickly become potholes and surface irregularities degenerate into rough surfaces. Within a short time, pavement conditions drop from fair to poor or very poor. At that point, the pavement and roadway requires complete reconstruction, which is 5 to 10 times more costly than preventive maintenance and periodic rehabilitation. The movement of freight, construction equipment, emergency vehicles, etc., is a critical part of the cleanup mission. As roads continue to degrade, this movement will begin operating outside of the safety envelope, increasing risk of injury/loss of life and risk of spill of fuels, oils, or hazardous materials and chemicals to the environment.

- Vacant facilities shall be monitored and maintained to ensure public and worker safety before demolition or transfer to other entities (i.e., Port of Benton, City of Richland, etc.) to meet their acceptance criteria. Isolation of utilities is required to minimize cost and potential for accidents or harm resulting from deteriorated system components. Regular S\&M will ensure that lead paint and asbestos are not being released into the environment and that the appropriate level of pest control is maintained. Disposition of vacant buildings in or near populated areas is required because they pose safety hazards associated with being an attractive nuisance.

- Utility service equipment and facility-related systems shall be replaced based on safety and environmental risk reasons. For example, the Landlord Project provides complete roof replacements, replacement of leaky Freon*-based chiller systems with non-ozone depleting based systems, and electrical and water system safety upgrades.

- NEPA Documentation--The Landlord Project activities are implemented based on completed and approved NEPA documentation.

\section{Planning Assumptions:}

- None.

4.2.5.1.7 Other Requirements and Planning Assumptions, Including DNFSB. None.

4.2.5.1.8 Interfaces. The Landlord Project shall interface with infrastructure operations to determine requirements for minimum safe, essential Site infrastructure maintenance.

"Freon is a trademark of E. I. DuPont de Nemours \& Company. 
The Landlord Project shall interface with infrastructure operations, and all Site projects, for the transfer of nonadioactively contaminated general-purpose-type facilities to the Landlord Project when the projects no longer need them. These facilities are identified in the Hanford Site Technical Baseline Database.

The Waste Management Program will provide solid waste, liquid waste, and analytical laboratory support as defined in the most recent approved revision of the solid waste, liquid waste, and Analytical Laboratory Services forecasts.

\subsection{Logic Diagram. Refer to Figure 4-7.}

\subsection{Requirements References.}

- 40 CFR 61, "National Emission Standards for Hazardous Air Pollutants"

- Federal Environmental Pesticide Control Act of 1972.

\subsection{Additional Planning Assumptions.}

- The funding level will remain constant at $\$ 10$ million to $\$ 20$ million per year from FY 1998 through 2006.

- Major system replacements are not anticipated nor funded at greater than $\$ 20$ million.

- A new FY 2001 line item project, "Sanitary Landfill Closure," will be initiated.

- Emphasis is on completing actual work rather than paper planning activities.

- Additional unanticipated funding will be invested in mortgage reduction activities.

\subsubsection{Infrastructure Project, Including Utilities, Roads and Grounds, Buildings, and Maintenance of Same, and Railroad.}

4.2.5.2.1 Project Description Summary. In tandem with the activities identified in the Hanford Site Landlord Project (Work Breakdown Structure 7.5) (Section 4.2.5.1), the mission of the Infrastructure Project is to preserve, upgrade, maintain, operate, and forecast cost-effective infrastructure support programs to facilitate the Hanford Site cleanup mission. Specific functions and services provided by the Infrastructure Project include utilities, transportation, generalpurpose facilities, and services. Support of cleanup also includes emphasis on mortgage reduction, risk reduction, a 10-year shutdown plan, asset conversion, and reduction of indirect costs. 
Figure 4-7. Logic Diagram for the Landlord Project.

\begin{tabular}{|c|c|c|c|c|c|}
\hline $\begin{array}{c}\text { Weto Stroents \& } \\
\text { Mattriats } \\
\end{array}$ & Cunent Loction & $\begin{array}{c}\text { Stonge Prior to } \\
\text { Traatment }\end{array}$ & Treatment/ Proceseaing & $\begin{array}{c}\text { Stonger Prior to } \\
\text { Eispoeal }\end{array}$ & $\begin{array}{c}\text { Dipposal/final } \\
\text { Diposetition }\end{array}$ \\
\hline \multirow{3}{*}{$\begin{array}{l}\text { Exous Non-Rsd } \\
\text { Buildings: }\end{array}$} & & & & & New Opner \\
\hline & $\begin{array}{l}\text { Verious Hanfotd } \\
\text { Sito Pasilitien }\end{array}$ & $\begin{array}{l}\text { Surveillanse \& } \\
\text { Maintenarice }\end{array}$ & $\begin{array}{l}\text { Denctivate to Chesp- } \\
\text { torkecp mode }\end{array}$ & & \\
\hline & & $\begin{array}{l}\text { Sured } \\
\text { Survibance \& } \\
\text { Maintenance }\end{array}$ & Denolition & & Off Sits Lendeilte \\
\hline
\end{tabular}

\subsection{Geographic Requirements/Assumptions.}

\section{Requirements:}

- Infrastructure shall be maintained in a minimum-safe condition to all Site locations where it is essential to accomplish project work.

- The Hanford Strategic Plan (RL 1996c) success indicators identify key mission indicators which must be achieved for successful cleanup. They include increased amount of land and other resources recovered for other (private and governmental) uses.

\section{Planning Assumptions:}

- None.

\subsection{Material and Waste Flow Requirements/Assumptions.}

\section{Requirements:}

- Requirements for transport of wastes and disposal of sanitary wastes are contained in the Hanford Site Technical Baseline Database.

\section{Planning Assumptions:}

- The site population will continue to decrease during the next 5 years.

- Liquid sanitary waste generation will average $94.6 \mathrm{~L}$ per day for personnel who take showers and $56.8 \mathrm{~L}$ per day for all other personnel. 
4.2.5.2.4 Facility Life-Cycle Requirements/Assumptions. The following table identifies life-cycle responsibility for major Infrastructure Project facilities. The Hanford Site Technical Baseline Database uses these data to define interfaces between Hanford Site projects. The life-cycle phases are those identified in DOE Order 430.1, Life-Cycle Asset Management (DOE 1995c).

\begin{tabular}{|l|c|l|l|l|}
\hline \multicolumn{1}{|c|}{ Major facility } & $\begin{array}{c}\text { Planning, } \\
\text { preconceptual, and } \\
\text { conceptual }\end{array}$ & Execution & Operations and maintenance* & Close out \\
\hline Electrical Systems & -- & -- & DynCorp Electrical Utilities & RL-TP13 \\
\hline Raw Water Systems & -- & -- & DynCorp Water Utilities & RL-TP13 \\
\hline Potable Water Systems & -- & -- & DynCorp Water Utilities & RL-TP13 \\
\hline Steam Systems & -- & -- & DynCorp/Johnson Controls & RL-TP13 \\
\hline $\begin{array}{l}\text { Liquid Sanitary Waste } \\
\text { Systems }\end{array}$ & -- & -- & DynCorp Sanitary Utilities & RL-TP13 \\
\hline Telecommunications & -- & -- & $\begin{array}{l}\text { Lockheed Martin Services, } \\
\text { Inc. }\end{array}$ & RL-TP13 \\
\hline Office Facilities & -- & -- & $\begin{array}{l}\text { DynCorp Facility } \\
\text { Management }\end{array}$ & RL-TP13 \\
\hline Shop Facilities & -- & -- & $\begin{array}{l}\text { DynCorp Facility } \\
\text { Maintenance and Site } \\
\text { Services }\end{array}$ & RL-TP13 \\
\hline Storage Facilities & -- & - & $\begin{array}{l}\text { DynCorp Materials } \\
\text { Management }\end{array}$ & RL-TP13 \\
\hline Land & -- & -- & $\begin{array}{l}\text { DynCorp Site \& Land Use } \\
\text { Planning }\end{array}$ & RL-TP13 \\
\hline Laboratories & -- & -- & Laboratory Management & RL-TP13 \\
\hline Road System & -- & $\begin{array}{l}\text { DynCorp Road Maintenance } \\
\text { and Services }\end{array}$ & RL-TP13 \\
\hline Rail System & -- & -- & DynCorp Rail Operations & RL-TP13 \\
\hline
\end{tabular}

*Indirect - No Project Breakdown Structure number.

4.2.5.2.5 Key Technical Requirements. The Infrastructure Project provides a safe infrastructure (e.g., utilities, transportation, general-purpose facilities, or sitewide services) in a cost-effective way that supports accomplishment of the Hanford Site mission and meets or exceeds appropriate standards. The primary technical requirements for the major facilities noted in Section 4.2.5.3.4 follow. NOTE: Solid sanitary waste disposal facilities are not included because these are provided by permitted landfills located offsite.

4.2.5.2.5.1 Electrical System. The electrical system includes substations, transformers, poles, lines, rights-of-way, and associated office, storage, and shop space necessary for operating the system in a safe and compliant manner.

DynCorp Tri-Cities Services, Inc. (DynCorp) Electrical Utilities is responsible for the Hanford Site electrical transmission and distribution system. This function receives electrical power from the Bonneville Power Administration; operates and maintains the 100 and 200 Areas; 300 Area, and 600 Area electrical systems; provides electrical dispatching; and provides sitewide PCB oil-leak cleanup services. Electrical power for the 700, 1100, and 3000 Areas is provided by the City of Richland. The 400 Area receives power directly from the Bonneville Power 
Administration with backup from the 300 Area. The Electrical Utilities function works with the Bonneville Power Administration and the City of Richland to ensure that forecasted electrical needs for the Hanford Site are met.

Requirements: Service requirements are projected by the customers and compiled and maintained in the Hanford Site Technical Baseline Database.

- 10 CFR 400-499, "Subchapter D--Energy Conservation"

- 40 CFR 761, "Polychlorinated Biphenyls (PCBs) Manufacturing, Processing, Distribution in Commerce, and Use Prohibitions."

\section{Planning Assumptions:}

- None.

4.2.5.2.5.2 Water Systems. The raw and potable water systems include river intake/ outfall structures, wells, pumps, pipes, reservoirs, treatment facilities, and associated office, storage, and shop space necessary for operating the system in a safe and compliant manner.

The DynCorp Utilities organization has Water Purveyor and drinking water monitoring program responsibilities (including administration and sampling in accordance with state drinking water regulations) for all water systems at the Hanford Site.

The raw water pumping capacity from the Columbia River to the Export Water System is $374,755 \mathrm{~L} / \mathrm{min}$ in the 100 Areas.

The 283-E Potable Water Treatment Plant receives raw water from the Export Water System and shall accommodate a maximum rated flow (capacity/capability) of 5,678 L/min. The average monthly potable water flow rate in the 200 East Area ranges between 3,028 and $3,312 \mathrm{~L} / \mathrm{min}$. Daily average flow rates can vary widely depending primarily on area activity. Flow rates as high as $4,542 \mathrm{~L} / \mathrm{min}$ have been observed during the flushing of lines subsequent to repair or during construction work that affects water usage. Daily flow rates as low as $1,514 \mathrm{~L} / \mathrm{min}$ are experienced on days when area activity is minimal.

The 283-W Potable Water Treatment Plant receives raw water from the Export Water System and shall accommodate a maximum rated flow (capacity/capability) of 5,678 L/min. The monthly average potable water flow rates in the 200 West Area range between 1,136 and $1,893 \mathrm{~L} / \mathrm{min}$. Daily average flow rates in the 200 West Area do not vary quite as much as in the 200 East Area, but ranges of between 946 and 2,839 L/min have been observed.

The 315 Potable Water Treatment Plant shall accommodate a maximum rated flow (capacity/capability) of $9,085 \mathrm{~L} / \mathrm{min}$ of potable water. The plant is designed to filter and chlorinate the raw water for potable uses, fire protection, and various process needs. Monthly average flow for customers in the 300 Area ranges between 3,785 and 5,489 L/min. An average 
Revision 0

reduction of $1,893 \mathrm{~L} / \mathrm{min}$ is expected due to the decrease of activity in the area. The water pumping capacity from the river is $75,708 \mathrm{~L} / \mathrm{min}$ in the 300 Area. A connection to the City of Richland water system exists as a backup.

The following facilities on the Hanford Site have independent water systems:

- The $100 \mathrm{~K}$ Area draws water directly from the Columbia River.

- The Supply System draws water directly from the Columbia River.

- The 400 Area draws water from wells.

- The Patrol Training Academy draws water from a well.

- The Yakima Barricade draws water from a well.

- The Laser Interferometer Gravitational Wave Observatory draws water from a well.

Requirements: Service requirements are projected by the customers and compiled and maintained in the Hanford Site Technical Baseline Database.

- Safe Drinking Water Act of 1974, Title XIV, "Safety of Public Water Systems"

- WAC 173-160, "Minimum Standards for Construction and Maintenance of Wells"

- WAC 173-200, "Water Quality Standards for Ground Waters of the State of Washington"

- WAC 173-303, "Dangerous Waste Regulations"

- WAC 173-304, "Minimum Functional Standards for Solid Waste Handling" (applies to sludges)

- WAC 246-290, "Public Water Supplies" (primary controlling document for water treatment plant operations)

- WAC 248-54, "Rules and Regulations of the State Board of Health Regarding Public Water Systems"

- WAC 248-54-175, "Maximum Contaminant Levels (MCL)."

\section{Planning Assumptions:}

- Rights to draw water from the Columbia were established for the defense mission. Water rights extend to the cleanup mission because it is the logical conclusion of the defense production mission. New site entities with other missions will have to connect to municipal water or obtain their own water rights.

- The 200 East Area water filter plant will be closed and all 200 Area potable water will be provided by the 200 West Area plant beginning in FY 1999. 
4.2.5.2.5.3 Steam System. The steam system includes steam power houses, fuel supply systems, water treatment systems, steam generation systems, steam piping, condensate traps, condensate return systems, exhaust and pollution reduction systems, control systems, and associated office, storage, and shop space necessary for operating the system in a safe and compliant manner.

The rated steam generating capacity for the 200 Area Steam function shall accommodate $131,542 \mathrm{~kg} / \mathrm{h}$ steam, operated at $1,551 \mathrm{kPa}$ and $232^{\circ} \mathrm{C}$. Steam production capability for FY 1997, based on boiler age, available personnel, and budget, is $104,326 \mathrm{~kg} / \mathrm{h}$. Expected steam production to meet customer's needs for FY 1997 will consist of a peak winter production of $45,360 \mathrm{~kg} / \mathrm{h}$ and a minimum summer production of $13,608 \mathrm{~kg} / \mathrm{h}$. The 200 East Area facility also provides for backup electrical generation which serves selected facilities including B Plant.

The rated steam-generating capacity for the 300 Area Steam function shall accommodate $81,647 \mathrm{~kg} / \mathrm{h}$, operated at $690 \mathrm{kPa}$ and $170^{\circ} \mathrm{C}$. Steam production capability for $\mathrm{FY} 1997$, based on boiler age, available personnel, and budget, is $63,503 \mathrm{~kg} / \mathrm{h}$. Expected steam production to meet customer needs for FY 1997 will consist of a peak winter production of $36,287 \mathrm{~kg} / \mathrm{h}$, and a minimum summer production of $6,804 \mathrm{~kg} / \mathrm{h}$. The 300 Area steam facility also provides central compressed air with a capacity/capability of $187 \mathrm{~m}^{3} / \mathrm{min}$. The FY 1997 demand for compressed air is not expected to exceed $22.7 \mathrm{~m}^{3} / \mathrm{min}$.

Backup electrical generation and distribution for 300 Area facilities is provided through the steam function. Total capacity/capability is 5,000 kVA with an FY 1997 demand of between 2,500 and $3,250 \mathrm{kVA}$ should it be needed.

The DOE has established an Energy Savings Performance Contract (ESPC) with Johnson Controls to provide alternative sources of steam and energy. The existing powerhouses will be operated until the ESPC is implemented (through November 1997), then prepared for shutdown.

\section{Requirements:}

- Service requirements are projected by the customers and compiled and maintained in the Hanford Site Technical Baseline Database.

\section{Planning Assumptions:}

- The ESPC contractor will be ready to take over energy production responsibilities using new facilities in December 1997.

4.2.5.2.5.4 Liquid Sanitary Waste Disposal System. The liquid sanitary waste disposal system includes piping, septic tanks, pumps, soil absorption systems, lagoons, monitoring systems, and associated office, storage, and shop space necessary for operating the system in a safe and compliant manner.

Requirements: Service requirements are projected by the customers and compiled and maintained in the Hanford Site Technical Baseline Database. 
Revision 0

- RCW 43.20.050, "Onsite Disposal of Solid and Liquid Wastes Act"

- WAC 173-200, "Water Quality Standards for Ground Waters of the State of Washington"

- WAC 173-216, "State Waste Discharge Permit Program" (for all discharges $>54,888 \mathrm{~L} /$ day)

- WAC 173-221, "Discharge Standards and Effluent Limitations for Domestic Wastewater Facilities"

- WAC 173-240, "Submission of Plans and Reports for Construction of Wastewater Facilities" (regulates systems under Ecology)

- WAC 173-304, "Minimum Functional Standards for Solid Waste Handling" (applies to · sludges)

- WAC 246-272 (formerly 248-96), "On-Site Sewage Systems" (regulates systems under Washington State Department of Health)

- 40 CFR 121, "National Pollutant Discharge Elimination System (NPDES) Permitting Program."

\section{Planning Assumptions:}

- None.

4.2.5.2.5.5 Telecommunications System. The telecommunications system includes wire, fiber optic cable, towers and transmission equipment, computers, radios, cameras, switches, and associated office, storage, and shop space necessary for operating the system in a safe and compliant manner.

Requirements: Service requirements are projected by the customers and compiled and maintained in the Hanford Site Technical Baseline Database.

- DOE Orders, specifically the 5300,5500 , and 5600 series.

\section{Planning Assumptions:}

- None.

4.2.5.2.5.6 Office Facilities. Office facilities include buildings used to house employees involved in administrative, engineering, training, or similar functions.

Requirements: Service requirements are projected by the customers and compiled and maintained in the Hanford Site Technical Baseline Database. 
- Federal Property Management Regulations, Temporary Regulation D-73, "Quality Workplace Environment" (GSA 1987).

\section{Planning Assumptions:}

- As population reductions progress, consolidation of facilities will continue.

4.2.5.2.5.7 Shop Facilities. Shop facilities include buildings used to house maintenance, fabrication, modeling, and associated office, storage, and shop space necessary for operating the facilities in a safe and compliant manner.

\section{Requirements:}

- Service requirements are projected by the customers and compiled and maintained in the Hanford Site Technical Baseline Database.

\section{Planning Assumptions:}

- Privatization or commercialization of some shop functions will begin in FY 1998.

4.2.5.2.5.8 Storage Facilities. Storage facilities include buildings used to protect equipment and supplies until they are needed or excessed.

Requirements: Service requirements are projected by the customers and compiled and maintained in the Hanford Site Technical Baseline Database.

- ASME/ANSI NQA-1-1994-IA, Quality Assurance Requirements for Nuclear Facility Applications (ASME/ANSI 1994) (related to records storage)

- Federal Property Management Regulations.

\section{Planning Assumptions:}

- Reductions in non-critical inventories will begin in FY 1998.

- A $20 \%$ reduction in warehousing space will be achieved by the end of FY 1999.

4.2.5.2.5.9 Land. This includes land, including rights-of-way, easements, quit claims, zoning, offsets, culturally sensitive areas, ecologically sensitive areas, and assignment for the use thereof.

Requirements: Service requirements are projected by the customers and compiled and maintained in the Hanford Site Technical Baseline Database.

- Executive Order 11988, "Floodplain Management"

- Executive Order 11990, "Protection of Wetlands"

- 10 CFR 1022, "DOE Floodplain and Wetlands Procedures." 
Planning Assumptions: The following assumptions are from the Hanford Strategic Plan.

- Access to DOE land used for disposal of radioactive waste will remain restricted as long as necessary to ensure adequate protection of human health and the environment.

- A final decision on the Comprehensive Land Use Plan will be made in the NEPA process or the HRA-EIS. Final decisions on cleanup levels for individual waste sites will be made in the CERCLA ROD process.

- Nuclear materials and HLW will eventually be sent offsite. Onsite interim safe, stable storage will be required.

- Groundwater use remains restricted for a yet-to-be-determined period. Final cleanup levels will be established within individual RODs or permit modifications.

4.2.5.2.5.10 Laboratory Facilities. Laboratory facilities include buildings housing research and development, bench-scale development, testing, and calibration functions, and associated office, storage, and shop space necessary for operating the facilities in a safe and compliant manner.

\section{Requirements:}

- Service requirements are projected by the customers and compiled and maintained in the Hanford Site Technical Baseline Database.

\section{Planning Assumptions:}

- None.

4.2.5.2.5.11 Road System. The road system includes the following driving surfaces along with associated office, storage, and shop space necessary for operating the system in a safe and compliant manner:

- $381 \mathrm{~km}$ of primary roads

- $106 \mathrm{~km}$ of secondary roads

- $563 \mathrm{~km}$ of other roads (gravel)

- 62 ha of paved parking lots.

Maintenance work performed is as follows.

- Inspect, maintain, and repair roads, pavements, shoulders, and striping.

- Sweep roads and remove snow and sand from roads and parking lots.

- Maintain Site perimeter fences. 
- Remove debris.

- Install and maintain traffic control, boundary fence, and river approach signs.

- Provide general Hanford Site excavation.

- Support the Hanford Fire Department on a 24-hour basis for range fires and other emergencies.

- Perform dust abatement.

- Monitor and maintain 31 active gravel pits used by Hanford Site contractors.

Requirements: Service requirements are projected by the customers and compiled and maintained in the Hanford Site Technical Baseline Database.

- Guidelines for Functional Classification (WSDOT 1982)

- MS-16, Asphalt in Pavement Maintenance (Asphalt 1977)

- Highway Capacity Manual (Highway Research Board 1965)

- M22-01, Design Manual (WSDOT 1986)

- ANSI-D6.1E-1989, Manual on Uniform Traffic Control Devices (ANSI 1989)

- Standard Specifications for RoadBridge/Municipal Construction (WSDOT 1984).

\section{Planning Assumptions:}

- Transportation of materials for TWRS, ERDF, and RCRA/CERCLA closures could create a significant increase in heavy truck traffic over some parts of the road system which would result in increased maintenance and repair requirements.

4.2.5.2.5.12 Rail System. The rail system includes track, bridges, crossings, sidings, locomotives, rolling stock, and associated office, storage, and shop space necessary for operating the system in a safe and compliant manner.

Rail operations include the following.

- Perform all rail movements on the Hanford Site, including delivery and switching of commercial receipts, off-plant rail shipments, and on-plant movements of bulk and liquid materials.

- Operate the Washington State certified scale house.

Rail maintenance includes maintaining the following:

- $112 \mathrm{~km}$ of active track

- 100 crossings

- 130 switches 
- 208,000 ties

- 1,500 signs

- 15 electrical signals

- 7 bridges/trestles

- Right-of-way vegetation control

- Snow and sand removal.

Requirements: Service requirements are projected by the customers and compiled and maintained in the Hanford Site Technical Baseline Database.

- 49 CFR 100-177, "Hazardous Materials Transportation"

- 49 CFR 210-240, "Federal Railroad Administration" as required by the Hanford Railroad Administration and Operations Matrix

- WHC Indirects - Workscope Reductions Approved by RL (Wagoner 1996b). The southern connection from Columbia Center to the 1100 Area will be maintained at Class III safety standards while the remaining track will be allowed to degenerate to Class I.

Planning Assumptions:

- Hanford Site requirements for rail service will stop by the end of FY 1998. The rail system will probably be transferred for other private or government use within the next 2 to 5 years.

\subsection{Project Safety Authorization Basis/NEPA and Permits.}

\section{Requirements:}

- All Infrastructure Project activities will be performed in an environmentally sound, safe, economical, prudent, and reliable manner.

\section{Planning Assumptions:}

- None.

\subsection{Other Requirements and Planning Assumptions, Including DNFSB.}

\section{Requirements:}

- Hanford Strategic Plan (RL 1996c) critical success factors, including the following:

- Optimize the Hanford Site Infrastructure

- Develop cost-competitive infrastructure commensurate with mission needs

- Involve staff and community in the outsourcing process 
Revision 0

- Federal Property Management Regulations, Part 101-25, "General" (GSA 1996)

- NFPA 101-1991, Life Safety Code (NFPA 1991)

- State Environmental Policy Act of 1971

- TSCA

- Uniform Building Code

- Uniform Fire Code

- Uniform Mechanical Code

- Uniform Plumbing Code

- American Society of Heating, Refrigerating, and Air-Conditioning Engineers standards.

\section{Planning Assumptions:}

- None.

4.2.5.2.8 Interfaces. With few exceptions, every aspect of the Infrastructure Project described in this project specification interfaces with every other project operating on the Hanford Site for provision of utilities and use of general-use facilities. In addition, facilities are transferred from the Infrastructure Project to the Landlord Project after being vacated and shut down as indicated by the table in Section 4.2.5.3.4.

The Waste Management Program will provide solid waste, liquid waste, and analytical laboratory support as defined in the most recent approved revision of the solid waste, liquid waste, and Analytical Laboratory Services forecasts.

4.2.5.2.9 Logic Diagram. Refer to Figure 4-8.

4.2.5.2.10 Requirements References. Comply with applicable sections of DOE Order 5480.19, Conduct of Operations Requirements for DOE Facilities (DOE 1990b), as identified in the Conduct of Operations applicability matrix approved by RL. An internal assessment process will be used to evaluate Conduct of Operations within Utilities.

4.2.5.2.11 Additional Planning Assumptions. None. 


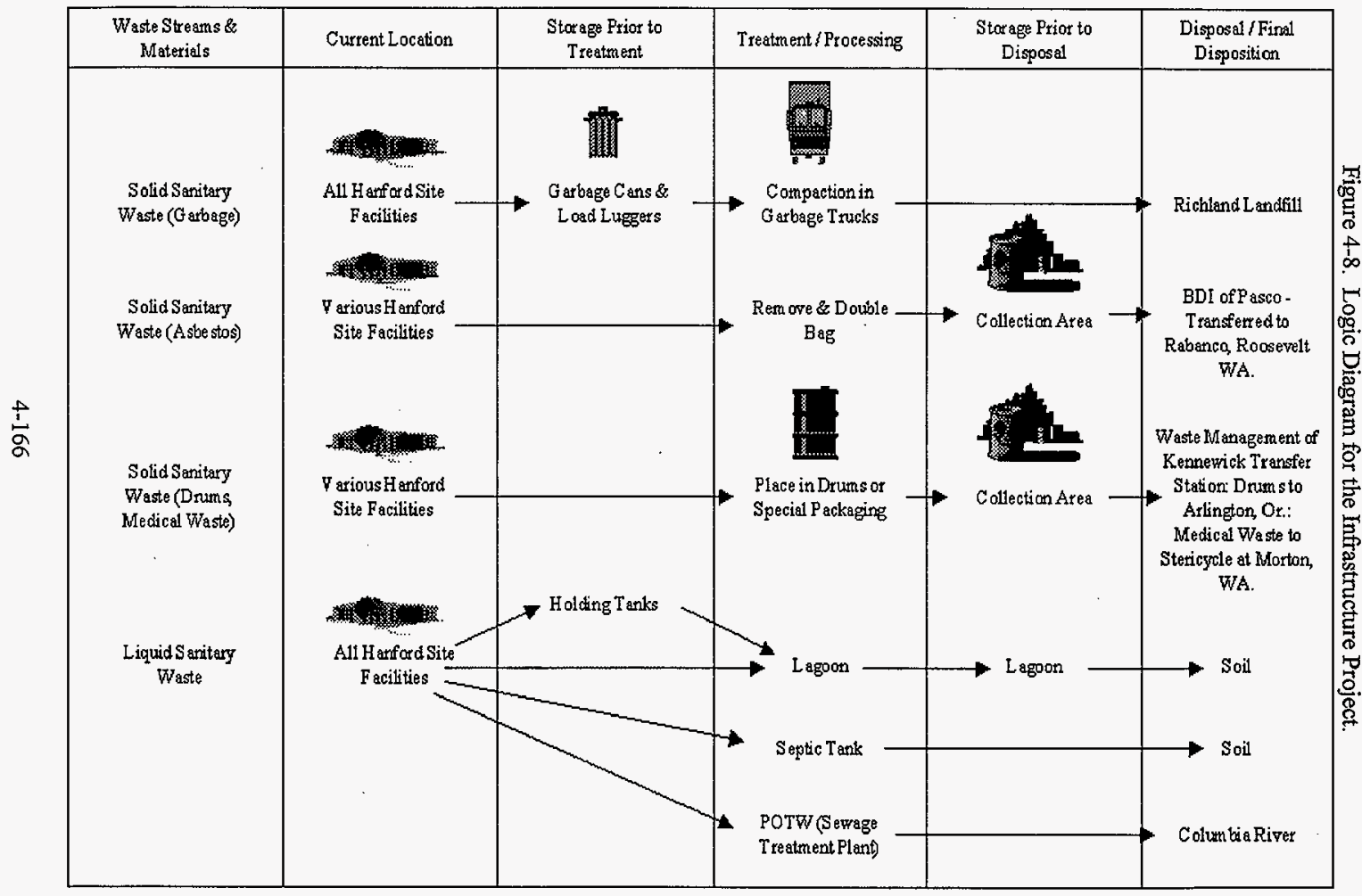


DOE/RL-97-55

Revision 0

February 2, 1998

Environmental Restoration Project

Concurrence: Qriginal signed by R. L. Clendenon Approved by: Qriginal signed by L. K. Bauer

on January 30, 1998

R. L.Clendenon,

Restoration Projects

Support Division,

U.S. Department of Energy,

Richland Operations Office on February 2, 1998

L. K. Bauer, Assistant Manager, Office of Assistant Manager for Environmental Management, U.S. Department of Energy, Richland Operations Office 
DOE/RL-97-55

Revision 0

February 2, 1998

\subsection{ER Project}

The logic diagram shown in Figure 4-9 applies to all facilities in the ER Project.

\subsubsection{Area Source Remedial Action Project}

The contractor shall provide the M\&I of activities required to assess and remediate past-practice waste sites in the 100 Area of the Hanford Site.

The 100 Area Source Remedial Action responsibilities include the following:

- Assessing the waste sites to determine the type and extent of contamination, such that a ROD for remediation of the waste sites can be prepared

- Preparing the remedial design and performing the remedial actions necessary to implement the ROD.

4.3.1.1 Project Description Summary. The 100 Area lies in the northern part of the Hanford Site, along the Columbia River. The area consists of six non-contiguous reactor areas containing more than 400 waste sites, 9 retired $\mathrm{Pu}$ production reactors, and their ancillary facilities. During operations, large amounts of cooling water flowed through the reactor cores and became contaminated with radionuclides and chemical contaminants. Soil and underlying groundwater were contaminated when cooling water was disposed in cribs and trenches and leaked from water transfer systems. Solid wastes contaminated with radionuclides were buried in unlined trenches. The soil contamination from the liquid and solid wastes contain low-level radiological wastes, MLLW, and chemical constituents. The groundwater contamination that exists in the 100 Area is addressed by the ER Groundwater Management Project.

One of the primary Hanford Site priorities is to focus initial remediation along the Columbia River. This project addresses this primary regulatory priority, as well as stakeholder and tribal nation values relative to protection of the Columbia River.

Remedial actions are designed to reduce risks to the public, workers, and the environment by removing and disposing of the contamination from the 100 Area waste sites. These actions will be taken in accordance with a ROD. The objective of the project is to clean up the 100 Area to a condition that will make the land suitable for other uses. The 100 Area Source Remedial Action Project will be followed by long-term monitoring to ensure cleanup standards continue to be met.

The 100 Area Source Remedial Action Project is organizationally part of the overall Remedial Action and ER Waste Disposal Project. 
Figure 4-9. Logic Diagram for the Environmental Restoration Project.

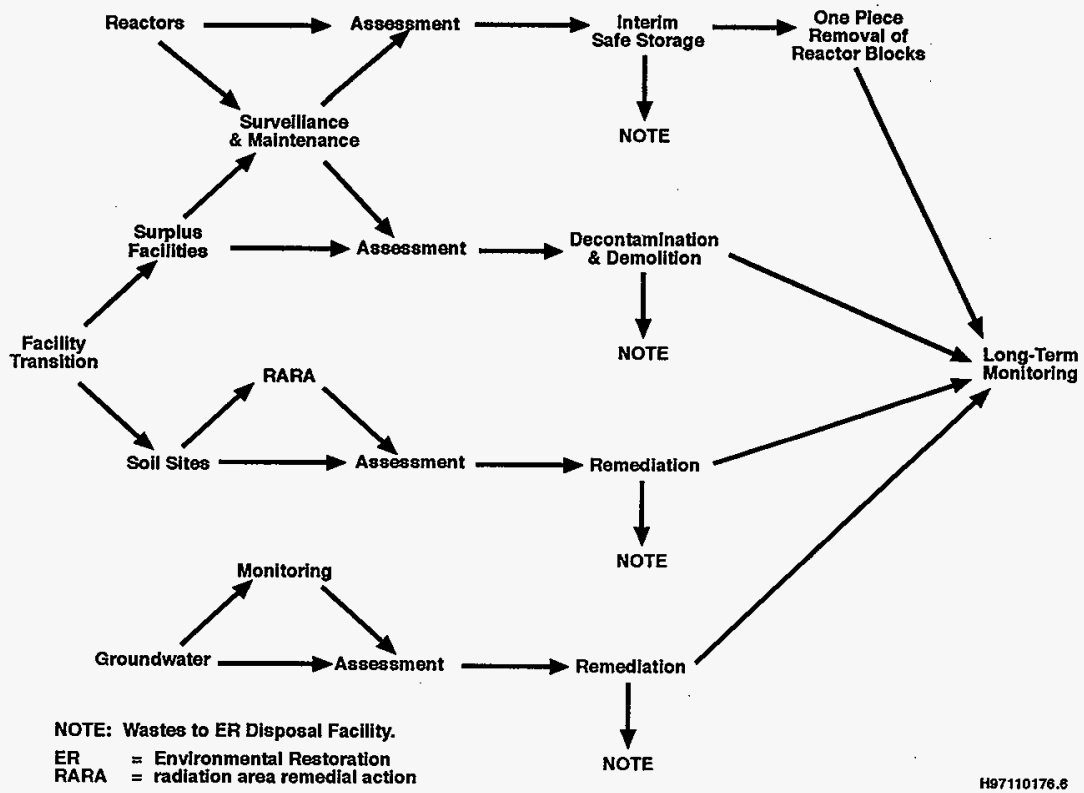

4.3.1.2 Geographic Requirements/Assumptions. The 100 Area is essentially equivalent to the area referenced in the Hanford Strategic Plan (RL 1996c) as the Reactors on the River.

\section{Reactors on the River}

Goal: Remove and/or stabilize SNF, surplus facilities, and waste sites to protect groundwater and the Columbia River, and ensure protection of public, the environment, and natural and cultural resources. Pending Congressional action on the Wild and Scenic River designation, use will continue to be restricted; sensitive ecological, cultural, and Native American resources will be protected.

Soil Sites End State:

- Soil sites will be remediated consistent with ROD cleanup standards.

- Final cleanup levels will be established within individual ROD or permit modifications. 
4.3.1.3 Material and Waste Flow Requirements/Assumptions. The 100 Area Source Remedial Action Project will achieve cleanup goals by excavating the contaminated soils. The ER Waste Disposal Project transports the excavated soils to the ERDF for final disposal. The estimated volume of soil to be removed from the 100 Area exceeds 2.3 million cubic meters.

4.3.1.4 Facility Life-Cycle Requirements/Assumptions. The following table identifies lifecycle responsibility for the 100 Area operable units. The life-cycle phases are those identified in DOE Order 430.1, Life-Cycle Asset Management (DOE 1995c). Remedial actions have been included in the D\&D phase.

\begin{tabular}{|c|c|c|c|c|c|c|c|c|c|}
\hline \multirow{3}{*}{ Major facility } & \multicolumn{9}{|c|}{ Life cycle } \\
\hline & \multirow{2}{*}{$\begin{array}{l}\text { Program } \\
\text { planning }\end{array}$} & \multirow[b]{2}{*}{ Preconceptual } & \multirow[b]{2}{*}{ Conceptual } & \multicolumn{3}{|c|}{ Execute } & \multirow[b]{2}{*}{$\begin{array}{l}\text { Ops and } \\
\text { maint }\end{array}$} & \multicolumn{2}{|c|}{ Close out } \\
\hline & & & & Design & Construct & Tumover & & $\begin{array}{c}\text { Post- } \\
\text { operation }\end{array}$ & $D \& D$ \\
\hline $\begin{array}{l}\text { Reactors on the } \\
\text { River Soil Site } \\
\text { Operable Units }\end{array}$ & RL-ER10 & -- & -- & $\cdots$ & $\cdots$ & - & -- & $\begin{array}{l}\text { RL-ER01 } \\
\text { RL-ER05 }\end{array}$ & $\begin{array}{l}\text { RL-ER01 } \\
\text { RL-ER07 } \\
\text { RL-ER09 }\end{array}$ \\
\hline
\end{tabular}

$\mathrm{D} \& \mathrm{D}=$ decontamination and decommissioning

4.3.1.5 Project Safety Authorization Basis/NEPA and Permits. The ER Project has prepared and will maintain BHI-00981, ERC Hazard Classification Matrices for Above Ground Structures and Groundwater and Soil Remediation Activities (Curry 1997), which provides the status of preliminary hazards classification process for the ER Project. This classification process is based on current DOE guidance for the classification of facilities and activities containing radionuclide and nonradiological hazardous material inventories.

4.3.1.6 Other Requirements and Planning Assumptions. The 100 Area Source Remedial Action Project will comply with the requirements and milestones of the Tri-Party Agreement.

4.3.1.7 Interfaces. The 100 Area Source Remedial Action Project's primary interface will be with the ER Waste Disposal Project for waste transportation and waste disposal. Additionally, the project will need to coordinate the logistics of the assessment and remediation activities with the ongoing Waste Management and D\&D activities.

The Waste Management Program will provide solid waste, liquid waste, and analytical laboratory support.

4.3.1.8 Logic Diagram. Refer to Figure 4-9.

4.3.1.9 Requirements References. None.

\subsubsection{Planning Assumptions.}

- The 100 Area soil cleanup standard will be residential, as defined in the initial ROD for the 100 Area.

- The contaminated soils removed from the 100 Area will be disposed in the ERDF. 
DOE/RL-97-55

Revision 0

February 2, 1998

- "Remove and dispose" is the expected remediation technology for all of the 100 Area waste sites.

- Remediated sites will be revegetated with native species.

- Analytical requirements for sampling of potential no action sites will be met by field screening and limited laboratory analysis.

- Resources, including labor analytical capabilities, equipment, and general infrastructure, will be available when required.

- No cost or schedule impacts will result from natural resource damage assessments.

- No removal or consolidation of pre-1970 unsegregated TRU waste is planned within the 100,200 , or 300 Areas.

- No remediation within the Columbia River is planned.

\subsubsection{Area Source Remedial Action Project}

The contractor shall provide the M\&I of activities required to assess and remediate past-practice waste sites in the 200 Area of the Hanford Site.

The 200 Area Source Remedial Action Project responsibilities include the following.

- Asses the waste sites to determine the type and extent of contamination, such that a ROD for remediation of the waste sites can be prepared.

- Prepare the remedial design and perform the remedial actions necessary to implement a ROD.

4.3.2.1 Project Description Summary. The 200 Area Source Remedial Action consists of approximately 700 waste sites located in and adjacent to the 200 East and 200 West Areas on the Central Plateau of the Hanford Site. These waste sites are primarily a result of the spent fuel processing activities that occurred in the 200 Areas. Soil and underlying groundwater were contaminated when liquid waste was disposed in cribs and trenches and leaked from transfer systems. Solid wastes contaminated with radionuclides were buried in unlined trenches. The soil contamination from the liquid and solid wastes contain low-level radiological wastes, MLLWs, and chemical constituents. The groundwater contamination that exists under the 200 Area is addressed by the ER Groundwater Management Project.

The remedial actions are designed to reduce the risk to the public, workers, and the environment by constructing engineered barriers to isolate the contamination in the 200 Area waste sites from the environment. These actions will be taken in accordance with a ROD. Much of the 200 Area will be used for management of contaminated media and disposal of wastes. The 
200 Area Source Remedial Action Project will be followed by long-term monitoring to ensure that cleanup standards continue to be met.

The 200 Area Source Remedial Action Project is organizationally part of the overall Remedial Action and ER Waste Disposal Project.

4.3.2.2 Geographic Requirements/Assumptions. The 200 Area is essentially equivalent to the area referenced in the Hanford Strategic Plan (RL 1996c) as the Central Plateau.

\section{Central Plateau}

Goal: The 200 Areas and Central Plateau will be used for the management, collection, and disposal of waste materials that remain onsite, and for other related and compatible uses. Cleanup levels and disposal standards will be established that are consistent with these long-term uses.

\section{Soil Sites End State:}

- Soil sites will be closed in place with surface barriers, or remedial alternatives will be established within individual ROD or permit modifications.

\subsubsection{Material and Waste Flow Requirements/Assumptions. The 200 Area Source}

Remedial Action Project planning assumption is that cleanup goals will be achieved by isolating contamination with barriers. If soil excavation is required, the ER Waste Disposal Project will transport the excavated soils to the ERDF for final disposal.

4.3.2.4 Facility Life-Cycle Requirements/Assumptions. The following table identifies lifecycle responsibility for the 200 Area Operable Units. The life-cycle phases are those identified in DOE Order 430.1, Life-Cycle Asset Management (DOE 1995c). Remedial actions have been included in the D\&D phase.

\begin{tabular}{|c|c|c|c|c|c|c|c|c|c|}
\hline \multirow{3}{*}{ Major facility } & \multicolumn{9}{|c|}{ Life cycle } \\
\hline & \multirow{2}{*}{$\begin{array}{l}\text { Program } \\
\text { planning }\end{array}$} & \multirow[b]{2}{*}{ Preconceptual } & \multirow[b]{2}{*}{ Conceptual } & \multicolumn{3}{|c|}{ Execute } & \multirow{2}{*}{$\begin{array}{c}\text { Operate \& } \\
\text { maintain }\end{array}$} & \multicolumn{2}{|c|}{ Close out } \\
\hline & & & & Design & Construct & Tumover & & $\begin{array}{c}\text { Post- } \\
\text { operation }\end{array}$ & $D \& D$ \\
\hline $\begin{array}{l}\text { Central Platcau Soil } \\
\text { Site Operable Units }\end{array}$ & RL-ER10 & $\cdots$ & $\cdots$ & $\cdots$ & $\cdots$ & - & -- & $\begin{array}{l}\text { RL-ER02 } \\
\text { RL-ER05 }\end{array}$ & $\begin{array}{l}\text { RL-ER02 } \\
\text { RL-ER07 }\end{array}$ \\
\hline $\begin{array}{l}\text { Low-Level Burial } \\
\text { Grounds }\end{array}$ & RLWM03 & $\cdots$ & $\cdots$ & -- & -- & -- & RL-WM03 & RL-WM03 & $\begin{array}{l}\text { RL-ER02 } \\
\text { RL-ER07 }\end{array}$ \\
\hline $\begin{array}{l}\text { Mixed Waste } \\
\text { Disposal Trenches }\end{array}$ & RL-WM03 & -. & -. & -- & -- & -. & RL-WM03 & RL-WM03 & $\begin{array}{l}\text { RL-ER02 } \\
\text { RL-ER07 }\end{array}$ \\
\hline
\end{tabular}

$\mathrm{D} \& \mathrm{D}=$ decontamination and decommissioning

4.3.2.5 Project Safety Authorization Basis/NEPA and Permits. The ER Project has prepared and will maintain BHI-00981, ERC Hazard Classification Matrices for Above Ground Structures and Groundwater and Soil Remediation Activities (Curry 1997), which provides the status of preliminary hazards classification process for the ER Project. This classification process is based 
on current $\mathrm{DOE}$ guidance for the classification of facilities and activities containing radionuclide and nonradiological hazardous material inventories.

4.3.2.6 Other Requirements and Planning Assumptions. The 200 Area Source Remedial Action Project will comply with the requirements and milestones of the Tri-Party Agreement.

4.3.2.7 Interfaces. If remedial action requires excavation and disposal, the 200 Area Source Remedial Action Project's primary interface will be with the ER Waste Disposal Project for waste transportation and waste disposal. Otherwise, the project will need to coordinate the logistics of the assessment and remediation activities with the ongoing Waste Management Project.

The Waste Management Program will provide solid waste, liquid waste, and analytical laboratory support.

4.3.2.8 Logic Diagram. Refer to Figure 4-9.

4.3.2.9 Requirements References. None.

\subsubsection{Planning Assumptions.}

- Waste sites will be closed in place with surface barriers, or remedial alternatives will be established within individual RODs or permit modifications.

- Isolation through the capping of waste sites with barriers is the expected remediation technology.

- If contaminated soils are removed from the 200 Area waste sites, they will be disposed in the ERDF.

- Remediated sites will be revegetated with native species.

- Resources, including labor analytical capabilities, equipment, and general infrastructure, will be available when required.

- Analytical requirements for sampling of potential no action sites will be met by field screening and limited laboratory analysis.

- No cost or schedule impacts will result from natural resource damage assessments.

- No removal or consolidation of pre-1970 unsegregated TRU waste is planned within the 100,200 , or 300 Areas.

- No remediation of SST or DST sites is planned within the ER Project. 
DOE/RL-97-55

Revision 0

February 2, 1998

\subsubsection{Area Source Remedial Action Project}

The contractor shall provide the M\&I of activities required to assess and remediate pastpractice waste sites in the 300 Area of the Hanford Site.

The 300 Area Source Remedial Action Project responsibilities include the following:

- Assessing the waste sites to determine type and extent of contamination such that a ROD for remediation of the waste sites can be prepared

- Preparing the remedial design and performing the remedial actions necessary to implement a ROD.

4.3.3.1 Project Description Summary. The 300 Area lies at the south end of the Hanford Site, adjacent to the northern boundary of the City of Richland and along the Columbia River. The 300 Area includes more than 100 waste sites. Soil and underlying groundwater were contaminated when process and laboratory liquids were disposed in process trenches and ponds. Solid wastes were disposed of in unlined trenches. The liquids and solid waste contained radionuclides and hazardous materials, primarily from fuel fabrication and laboratory activities.

These disposal practices resulted in contamination of the soil and underlying groundwater. The groundwater is addressed by the Groundwater Management Project.

One of the Hanford Site priorities is to focus initial remediation along the Columbia River. This project addresses this primary regulatory priority, as well as stakeholder and tribal nation values relative to protection of the Columbia River.

Remedial actions are designed to reduce risks to the public, workers, and the environment by removing the contamination in the 300 Area waste sites from the environment. These actions will be taken in accordance with a ROD. The objective of the remedial actions is to make the land available for industrial use. The 300 Area Source Remedial Action Project will be followed by long-term monitoring to ensure cleanup standards continue to be met.

The 300 Area Source Remedial Action Project is organizationally part of the overall Remedial Action and ER Waste Disposal Project.

4.3.3.2 Geographic Requirements/Assumptions. The 300 Area includes the majority of the waste sites in the area referenced in the Hanford Strategic Plan (RL 1996c) as the South 600 Area.

\section{South 600 Area}

Goal: The 300 Area waste sites, materials, and facilities will be remediated to allow industrial and economic diversification opportunities. The federal government will retain ownership of land in and adjacent to the 300 and 400 Areas, but will lease land for private and 
public uses to support regional industrial and economic development. Excess land within the 1100 Area will be targeted for transition to non-federal ownership.

Soil Sites End State:

- Soil sites will be remediated consistent with ROD cleanup standards. Contaminated media will be consolidated and moved to the 200 Area for disposal.

- Final cleanup levels will be established within individual ROD or permit modifications.

\subsubsection{Material and Waste Flow Requirements/Assumptions. The 300 Area Source}

Remedial Action Project will achieve the cleanup goals by excavating the contaminated soils. The ER Waste Disposal Project transports the excavated soils to the ERDF for final disposal. The estimated volume of soil to be removed from the 300 Area exceeds 750,000 cubic meters.

4.3.3.4 Facility Life-Cycle Requirements/Assumptions. The following table identifies lifecycle responsibility for the 300 Area Operable Units. The life-cycle phases are those identified in DOE Order 430.1, Life-Cycle Asset Monagement (DOE 1995c). Remedial actions have been included in the D\&D phase.

\begin{tabular}{|c|c|c|c|c|c|c|c|c|c|}
\hline \multirow{3}{*}{ Major facility } & \multicolumn{9}{|c|}{ Life cycle } \\
\hline & \multirow{2}{*}{$\begin{array}{l}\text { Program } \\
\text { planning }\end{array}$} & \multirow[b]{2}{*}{ Preconceptual } & \multirow[b]{2}{*}{ Conceptual } & \multicolumn{3}{|c|}{ Execute } & \multirow[b]{2}{*}{$\begin{array}{c}\text { Operate \& } \\
\text { maintain }\end{array}$} & \multicolumn{2}{|c|}{ Close out } \\
\hline & & & & Design & Construet & Tumover & & $\begin{array}{c}\text { Post- } \\
\text { operation }\end{array}$ & $\mathrm{D} \& D$ \\
\hline $\begin{array}{l}\text { South } 600 \text { Area Soil } \\
\text { Site Operable Units }\end{array}$ & RL-ER10 & -- & $\cdots$ & $\cdots$ & - & $-\cdot$ & -- & $\begin{array}{l}\text { RL-ER03 } \\
\text { RL-ER05 }\end{array}$ & $\begin{array}{l}\text { RL-ER03 } \\
\text { RL-ER07 }\end{array}$ \\
\hline
\end{tabular}

$\mathrm{D} \& \mathrm{D}=$ decontamination and decommissioning

4.3.3.5 Project Safety Authorization Basis/NEPA and Permits. The ER Project has prepared and will maintain BHI-00981, ERC Hazard Classification Matrices for Above Ground Structures and Groundwater and Soil Remediation Activities (Curry 1997), which provides the status of preliminary hazards classification process for the ER Project. This classification process is based on current DOE guidance for the classification of facilities and activities containing radionuclide and nonradiological hazardous material inventories.

4.3.3.6 Other Requirements and Planning Assumptions. The 300 Area Source Remedial Action Project will comply with the requirements and milestones of the Tri-Party Agreement.

4.3.3.7 Interfaces. The 300 Area Source Remedial Action Project's primary interface is with the ER Waste Disposal Project for waste transportation and waste disposal. Additionally, the project will need to coordinate the logistics of the assessment and remediation activities with the ongoing Waste Management Project and Landlord Project.

The Waste Management Program will provide solid waste, liquid waste, and analytical laboratory support. 
4.3.3.8 Logic Diagram. Refer to Figure 4-9.

4.3.3.9 Requirements References. None.

\subsubsection{Planning Assumptions.}

- The 300 Area soil cleanup standard will be industrial, as defined in the initial ROD for the 300 Area.

- The contaminated soils removed from the 300 Area will be disposed in the ERDF.

- Remediated sites will be revegetated with native species.

- Resources, including labor, analytical capabilities, equipment, and general infrastructure, will be available when required.

- Analytical requirements for sampling of potential no action sites will be met by field screening and limited laboratory analysis.

- No cost or schedule impacts will result from natural resource damage assessments.

- No removal or consolidation of pre-1970 unsegregated TRU waste is planned within the 100,200 , or 300 Areas.

- No remediation within the Columbia River is planned.

\subsubsection{ER Waste Disposal Project}

The contractor shall provide the $M \& I$ of activities required to transport waste, operate the ERDF, and construct an additional disposal capacity as required to support the ER Project.

The contractor shall be responsible for the following:

- Managing and integrating the transportation of waste from the remedial action waste sites to the ERDF

- Managing the operation and monitoring of the ERDF

- Managing and integrating the design and construction of additional disposal capacity for the ERDF

- Managing the interim and final closure of the ERDF.

4.3.4.1 Project Description Summary. The ERDF is located in the center of the Hanford Site, between the 200 East and 200 West Areas. The ERDF is a large-scale, evolving landfill, 
complete with ancillary facilities, designed to receive and isolate low-level radioactive, hazardous waste, or a combination thereof. The ERDF is a RCRA-compliant landfill that is authorized under CERCLA. The facility also complies with the substantive applicable or relevant and appropriate requirements, including WAC 173-303, "Dangerous Waste Regulations," and U.S. Environmental Protection Agency and DOE codes, Orders, standards, and regulations. The ERDF is designed to provide the disposal capacity, as needed, to accommodate projected waste volumes during the next 20 to 30 years.

The initial two cells are $21 \mathrm{~m}$ deep, $305 \mathrm{~m}$ long (two cells at $152.4 \mathrm{~m}$ ), and $229 \mathrm{~m}$ wide. The cells are lined with a RCRA Subtitle C-type liner and have a leachate collection system. The total estimated volume of materials to be disposed in the ERDF exceeds 3 million cubic meters. The ER Waste Disposal Project will be followed by long-term monitoring to ensure disposal standards continue to be met.

The ER Waste Disposal Project is organizationally part of the overall Remedial Action and ER Waste Disposal Project.

4.3.4.2 Geographic Requirements/Assumptions. The ERDF is in the area referenced in the Hanford Strategic Plan (RL 1996c) as the Central Plateau. The ERDF will be constructed, operated, and closed in support of the Central Plateau goal and end states.

\section{Central Plateau}

Goal: The 200 Areas and Central Plateau will be used for the management of NM, the collection and disposal of waste materials that remain onsite, and for other related and compatible uses. Cleanup levels and disposal standards will be established that are consistent with these long-term uses.

Soil Sites End State:

- Soil sites will be closed in place with surface barriers, or remedial alternatives will be established within individual ROD or permit modifications.

Groundwater End State:

- Groundwater use remains restricted for a yet-to-be-determined period; groundwater will be intercepted or contained to within designated boundaries.

- Final cleanup levels will be established within individual RODs or permit modifications.

Facilities End State:

- Dismantle, or close, through entombment, D\&D facilities currently assigned to the ER Program. 
- Remove non-essential, surplus buildings and facilities that do not have identified post-cleanup uses.

4.3.4.3 Material and Waste Flow Requirements/Assumptions. The ERDF is designed to provide disposal capacity, as needed, to accommodate projected waste volumes during the next 20 to 30 years. The total estimated volume of materials to be disposed of in the ERDF exceeds 3 million cubic meters.

Any leachate collected from the ERDF, if required, will be treated at the 200 Area ETF.

4.3.4.4 Facility Life-Cycle Requirements/Assumptions. The following table identifies lifecycle responsibility for the ERDF. The life-cycle phases are those identified in DOE Order 430.1, Life-Cycle Asset Management (DOE 1995c).

\begin{tabular}{|c|c|c|c|c|c|c|c|c|c|}
\hline \multirow{3}{*}{ Major facility } & \multicolumn{9}{|c|}{ Life cycle } \\
\hline & \multirow{2}{*}{$\begin{array}{l}\text { Program } \\
\text { planning }\end{array}$} & \multirow{2}{*}{ Preconceptual } & \multirow[b]{2}{*}{ Conceptual } & \multicolumn{3}{|c|}{ Execute } & \multirow[b]{2}{*}{$\begin{array}{l}\text { Ops and } \\
\text { maint }\end{array}$} & \multicolumn{2}{|c|}{ Close out } \\
\hline & & & & Design & Construct & Turnover & & $\begin{array}{c}\text { Post- } \\
\text { operation }\end{array}$ & D\&D \\
\hline $\begin{array}{l}\text { Environmental } \\
\text { Restoration Disposal } \\
\text { Facility }\end{array}$ & RL-ER10 & - & - & -- & 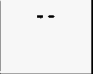 & - & RL-ER04 & RL-ER04 & $\begin{array}{l}\text { RL-ER04 } \\
\text { RL-ER07 }\end{array}$ \\
\hline
\end{tabular}

$\mathrm{D} \& \mathrm{D}=$ decontamination and decommissioning

4.3.4.5 Project Safety Authorization Basis/NEPA and Permits. The ER Project has prepared and will maintain BHI-00981, ERC Hazard Classification Matrices for Above Ground Structures and Groundwater and Soil Remediation Activities (Curry 1997), which provides the status of preliminary hazards classification process for the ER Project. This classification process is based on current DOE guidance for the classification of facilities and activities containing radionuclide and nonradiological hazardous material inventories.

4.3.4.6 Other Requirements and Planning Assumptions. The ER Waste Disposal Project will comply with the requirements and milestones of the Tri-Party Agreement. The ERDF is a RCRAcompliant landfill that is authorized under CERCLA. The facility also complies with the substantive applicable or relevant and appropriate requirements, including WAC 173-303, "Dangerous Waste Regulations," and U.S. Environmental Protection Agency and DOE codes, Orders, standards, and regulations.

4.3.4.7 Interfaces. The ER Waste Disposal Project's primary interface is with the 100 Area, 200 Area, and 300 Area Remedial Action and D\&D Projects for waste transportation and waste disposal. Additionally, the project interfaces with the Waste Management Project for treatment of the ERDF leachate.

The Waste Management Program will provide solid waste, liquid waste, and analytical laboratory support.

4.3.4.8 Logic Diagram. Refer to Figure 4-9. 


\subsubsection{Requirements References. None.}

\subsubsection{Planning Assumptions.}

- The ERDF will only accept waste generated by the Hanford Site ER Project.

- The ERDF will be expanded, as required, to meet the needs of the ER Project.

- The ERDF is designed to provide the disposal capacity, as needed, to accommodate projected waste volumes during the next 20 to 30 years.

- The ER Waste Disposal Project will comply with the requirements and milestones of the Tri-Party Agreement.

- Resources, including labor, analytical capabilities, equipment, and general infrastructure, will be available when required.

- Any leachate collected from the ERDF, if required, will be treated at the 200 Area ETF.

- The ERDF will not include any facilities for treatment of the waste materials. Some grouting may be used for subsidence control.

\subsubsection{S\&M Project}

The contractor shall provide the M\&I of surveillance and maintenance of waste sites and facilities assigned to the ER Project.

The S\&M Project shall be responsible for the following:

- Managing and integrating the S\&M of inactive facilities assigned to the ER Project

- Managing and integrating the radiation area remedial action activities

- Managing and integrating the transition to the ER Project of inactive facilities from other EM Projects at the Hanford Site.

$\mathrm{S} \& \mathrm{M}$ is divided into the following two key areas:

- Inactive facility S\&M

- Radiation area remedial action.

4.3.5.1 Project Description Summary. The Hanford Site contains many surplus facilities remaining from past $\mathrm{Pu}$ production activities that were required by the U.S. Department of Defense from World War II through the Cold War. These facilities are now aged and 
DOE/RL-97-55

Revision 0

February 2, 1998

deteriorating. Because the facilities no longer have a production mission, they must be either maintained (to preserve their integrity) or removed to (1) preclude the escape of potentially hazardous substances to the accessible environment, or (2) present unacceptable industrial safety risks. The S\&M activities are required on waste sites and facilities located throughout the Hanford Site.

In addition, this project includes the transition activities involved in the ER Project's acceptance of new facilities from other DOE programs through the deactivation process.

The purpose of the S\&M function for contaminated surplus facilities awaiting decommissioning is as follows.

- Ensure adequate containment of contamination.

- Provide physical SAS controls.

- Maintain the facilities in a manner that will minimize potential hazards to the public and workers.

- Maintain systems and equipment that will be essential for D\&D activities in a shutdown but standby/operational mode.

- Provide a mechanism for the identification and compliance with applicable ES\&H and SAS requirements.

In parallel with S\&M, the risk assessment/corrective maintenance program performs vital corrective maintenance actions in the surplus facilities. The purpose of the program is to establish and maintain the surplus facilities in a safe condition until the buildings are dismantled or released for other uses.

The S\&M Project is responsible for radiation area remedial action on approximately 800 inactive waste sites, including 10 RCRA TSD units. The inactive waste sites include unplanned release sites, cribs, trenches, ponds, and burial grounds. The waste sites are in the 100 , 200,300 , and 600 Areas of the Hanford Site.

The S\&M is required until the facilities are decommissioned and waste sites remediated. The S\&M Project is organizationally part of the overall ER S\&M Project.

4.3.5.2 Geographic Requirements/Assumptions. The S\&M Project will support the goals and end states for all areas of the Hanford Site.

4.3.5.3 Material and Waste Flow Requirements/Assumptions. The S\&M Project produces limited waste quantities.

4.3.5.4 Facility Life-Cycle Requirements/Assumptions. The following table identifies the S\&M Project facility responsibilities. The life-cycle phases are those identified in 
DOE Order 430.1, Life-Cycle Asset Management (DOE 1995c). Surveillance and maintenance are included in the post-operations phase.

\begin{tabular}{|c|c|c|c|c|c|c|c|c|c|}
\hline \multirow{3}{*}{ Major facility } & \multicolumn{6}{|c|}{ Life cycle } & \multirow{3}{*}{$\begin{array}{l}\text { Ops \& } \\
\text { maint }\end{array}$} & \multirow{2}{*}{\multicolumn{2}{|c|}{ Close out }} \\
\hline & \multirow{2}{*}{$\begin{array}{l}\text { Program } \\
\text { planning }\end{array}$} & \multirow{2}{*}{$\begin{array}{c}\text { Pre- } \\
\text { conceptual }\end{array}$} & \multirow[b]{2}{*}{ Conceptual } & \multicolumn{3}{|c|}{ Execute } & & & \\
\hline & & & & Design & Construct & Turnover & & $\begin{array}{c}\text { Post- } \\
\text { operation } \\
\end{array}$ & $\mathrm{D} \& \mathrm{D}$ \\
\hline $100 \mathrm{~K}$ Area Facilities & $\begin{array}{c}\text { RL- } \\
\text { WM01 } \\
\text { RL-TP09 } \\
\end{array}$ & -- & $\therefore$ & $\cdots$ & $\cdots$ & - & RL-WMOI & $\begin{array}{l}\text { RL-TP09 } \\
\text { RL-ER05 }\end{array}$ & $\begin{array}{l}\text { RL-ER06 } \\
\text { RL_ER07 }\end{array}$ \\
\hline 242-A Evaporator & $\begin{array}{l}\text { RL- } \\
\text { WM05 }\end{array}$ & -- & $\cdots$ & $\cdots$ & $\cdots$ & $\cdots$ & RL-WMOS & $\begin{array}{l}\text { RL-TP10 } \\
\text { RL-ER05 }\end{array}$ & $\begin{array}{l}\text { RL-ER06 } \\
\text { RL-ER07 }\end{array}$ \\
\hline $\begin{array}{l}\text { Plutonium-Uranium } \\
\text { Extraction Plant }\end{array}$ & RL-TP03 & $\cdots$ & $\cdots$ & -- & -- & -- & $\cdots$ & $\begin{array}{l}\text { RI-TP03 } \\
\text { RL-ER05 }\end{array}$ & $\begin{array}{l}\text { RL-ER06 } \\
\text { RL-ER07 } \\
\end{array}$ \\
\hline B Plant & RI-TP01 & $\cdots$ & -- & -- & $\cdots$ & $\because$ & $\cdots$ & $\begin{array}{l}\text { RL-TP01 } \\
\text { RL-ER05 }\end{array}$ & $\begin{array}{l}\text { RL-ER06 } \\
\text { RL-ER07 }\end{array}$ \\
\hline $\begin{array}{l}\text { Waste Encapsulation } \\
\text { and Storage Facility }\end{array}$ & RL-TP02 & $\cdots$ & -- & -- & -- & $\cdots$ & RL-TP02 & $\begin{array}{l}\mathrm{RL}-\mathrm{TP} 02 \\
\mathrm{RI}-\mathrm{ER} 05 \\
\end{array}$ & $\begin{array}{l}\text { RL-ER06 } \\
\text { RL-ER07 }\end{array}$ \\
\hline $\begin{array}{l}\text { Plutonium Finishing } \\
\text { Plant }\end{array}$ & RL-TP07 & -- & 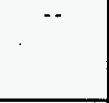 & $\cdots$ & $\cdots$ & -- & $\begin{array}{l}\text { RL-TP07 } \\
\text { RL-TP05 } \\
\text { RL-TP06 }\end{array}$ & $\begin{array}{l}\text { RL-TP07 } \\
\text { RL-ER05 } \\
\text { RL-TP05 } \\
\text { RL-TP06 }\end{array}$ & $\begin{array}{l}\text { RL-ER06 } \\
\text { RL-ER07 }\end{array}$ \\
\hline $\begin{array}{l}\text { Reduction-Oxidation } \\
\text { Plant }\end{array}$ & RL-ER02 & -. & -- & -- & -- & $\cdots$ & $\cdots$ & RL-ER05 & $\begin{array}{l}\text { RL-ER06 } \\
\text { RL-ER07 }\end{array}$ \\
\hline Uranium Oxide Plant & RL-ER02 & $\cdots$ & - & $\cdots$ & $\cdots$ & $\cdots$ & - & RL-ER05 & $\begin{array}{l}\text { RL-ER06 } \\
\text { RL-ER07 }\end{array}$ \\
\hline T Plant Facility & $\begin{array}{c}\text { RI- } \\
\text { WM04 }\end{array}$ & -- & $\cdots$ & -- & -- & -- & RL-WM04 & $\begin{array}{c}\text { RL-TP10 } \\
\text { RL-ER05 } \\
\text { RL- } \\
\text { WM04 } \\
\end{array}$ & $\begin{array}{l}\text { RL-ER06 } \\
\text { RL-ER07 }\end{array}$ \\
\hline $2706-\mathrm{T}$ & $\begin{array}{c}\mathrm{RL}- \\
\mathrm{WMO} 4\end{array}$ & 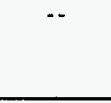 & -- & $\cdots$ & $\cdots$ & -- & RL-WMO4 & $\begin{array}{c}\text { RL-TP10 } \\
\text { RL-ER05 } \\
\text { RL- } \\
\text { WM04 } \\
\end{array}$ & $\begin{array}{l}\text { RL-ER06 } \\
\text { RL-ER07 }\end{array}$ \\
\hline M-91 Facility & $\begin{array}{c}\mathrm{RL} \\
\mathrm{WM04}\end{array}$ & RL-WM04 & RL-WM04 & $\begin{array}{c}\text { RL- } \\
\text { WM04 }\end{array}$ & RL-WMO4 & $\begin{array}{c}\text { RL- } \\
\text { WM04 }\end{array}$ & RL-WMO4 & $\begin{array}{c}\mathrm{RI}- \\
\mathrm{WM} 04\end{array}$ & $\begin{array}{l}\text { RI- } \\
\text { WMO4 }\end{array}$ \\
\hline WRAP Module 1 & $\begin{array}{c}\text { RL- } \\
\text { WM04 }\end{array}$ & $\cdots$ & -- & -- & - & $\cdots$ & RL-WM04 & $\begin{array}{c}\text { RI- } \\
\text { WM04 }\end{array}$ & $\begin{array}{l}\mathrm{RI}- \\
\mathrm{WMO4}\end{array}$ \\
\hline $\begin{array}{l}200 \text { Area Effluent } \\
\text { Treatment Facility }\end{array}$ & $\begin{array}{c}\text { RL- } \\
\text { WMOS }\end{array}$ & $\cdots$ & -- & -- & -- & $\cdots$ & RI-WM05 & $\begin{array}{l}\text { RL-TP10 } \\
\text { RL-ER05 } \\
\end{array}$ & $\begin{array}{l}\text { RL-ER06 } \\
\text { RL-ER07 } \\
\end{array}$ \\
\hline $\begin{array}{l}\text { Canister Storage } \\
\text { Building }\end{array}$ & $\begin{array}{c}\text { RL- } \\
\text { WM01 } \\
\text { RL-TW10 }\end{array}$ & $\cdots$ & $\cdots$ & -- & $\begin{array}{l}\text { RL-WM01 } \\
\text { RL-TW09 }\end{array}$ & $\begin{array}{c}\text { RL- } \\
\text { WM01 } \\
\text { RL-TW09 }\end{array}$ & $\begin{array}{l}\mathrm{RL}-\mathrm{WMO} 2 \\
\mathrm{RL}-\mathrm{TW09} \\
\mathrm{RL}-\mathrm{WMO1}\end{array}$ & $\begin{array}{c}\text { RL- } \\
\text { WM02 } \\
\text { RL-TW09 }\end{array}$ & $\begin{array}{l}\text { RL- } \\
\text { WM02 } \\
\text { RL-TW09 }\end{array}$ \\
\hline $\begin{array}{l}\text { Central Waste } \\
\text { Complex }\end{array}$ & $\begin{array}{c}\text { RI- } \\
\text { WM03 }\end{array}$ & $\cdots$ & $\cdots$ & -- & -- & -- & RL-WM03 & $\begin{array}{c}\text { RL- } \\
\text { WM03 }\end{array}$ & $\begin{array}{l}\text { RL-ER06 } \\
\text { RL-ER07 } \\
\end{array}$ \\
\hline $\begin{array}{l}\text { Nonradioactive } \\
\text { Dangerous Waste } \\
\text { Storage Facility }\end{array}$ & $\begin{array}{c}\mathrm{RL} \\
\text { WM03 }\end{array}$ & $\cdots$ & -- & $\cdots$ & $\cdots$ & $\cdots$ & $\cdots$ & $\begin{array}{c}\text { RL- } \\
\text { WM03 }\end{array}$ & $\begin{array}{l}\text { RL-ER06 } \\
\text { RL-ER07 }\end{array}$ \\
\hline $\begin{array}{l}\text { Liquid Effluent } \\
\text { Retention Frcility }\end{array}$ & $\begin{array}{c}\text { RL- } \\
\text { WM05 }\end{array}$ & $\cdots$ & -- & -- & -- & -- & RL-WM05 & $\begin{array}{l}\text { RL-TP10 } \\
\text { RL-ER05 } \\
\end{array}$ & $\begin{array}{l}\text { RL-ER06 } \\
\text { RL-ER07 } \\
\end{array}$ \\
\hline $\begin{array}{l}\text { Transuranic Storage } \\
\text { and Assay Facility }\end{array}$ & $\begin{array}{c}\text { RL- } \\
\text { WM03 }\end{array}$ & -- & -- & $\cdots$ & - & -- & $\mathrm{RL}-\mathrm{WM} 03$ & $\begin{array}{c}\text { RL-TP10 } \\
\text { RL-ER05 } \\
\text { RL- } \\
\text { WM03 }\end{array}$ & $\begin{array}{l}\text { RL-ER06 } \\
\text { RL-ER07 }\end{array}$ \\
\hline
\end{tabular}


DOE/RL-97-55

Revision 0

February 2, 1998

\begin{tabular}{|c|c|c|c|c|c|c|c|c|c|}
\hline \multirow{3}{*}{ Major facility } & \multicolumn{9}{|c|}{ Life cycle } \\
\hline & \multirow{2}{*}{$\begin{array}{l}\text { Program } \\
\text { planning }\end{array}$} & \multirow{2}{*}{$\begin{array}{c}\text { Pre- } \\
\text { conceptual }\end{array}$} & \multirow[b]{2}{*}{ Conceptual } & \multicolumn{3}{|c|}{ Execute } & \multirow{2}{*}{$\begin{array}{l}\text { Ops \& } \\
\text { maint }\end{array}$} & \multicolumn{2}{|c|}{ Close out } \\
\hline & & & & Design & Construct & Turnover & & $\begin{array}{c}\text { Post- } \\
\text { operation }\end{array}$ & D\&D \\
\hline 222-\$ Laboratory & $\underset{\text { WMO }}{\text { RI- }}$ & -- & -- & -- & -- & -- & RL-WM06 & $\begin{array}{c}\text { RL-TP10 } \\
\text { RL-ER05 } \\
\text { RL } \\
\text { WM06 }\end{array}$ & $\begin{array}{l}\text { RL-ER06 } \\
\text { RL-ER07 }\end{array}$ \\
\hline $\begin{array}{l}\text { Waste Sampling and } \\
\text { Characterization } \\
\text { Facility }\end{array}$ & $\begin{array}{c}\text { RL. } \\
\text { WM06 }\end{array}$ & - & $\cdots$ & $\cdots$ & $\ldots$ & -. & $\mathrm{RL}-\mathrm{WM} 06$ & $\begin{array}{c}\text { Rr } \\
\text { WM06 }\end{array}$ & $\begin{array}{l}\text { RI-ER06 } \\
\text { RL-ER07 }\end{array}$ \\
\hline $\begin{array}{l}340 \text { Waste Handling } \\
\text { Facility }\end{array}$ & $\begin{array}{c}\text { RL- } \\
\text { WM05 }\end{array}$ & -- & -- & $\cdots$ & -- & -- & RL-WMOS & $\begin{array}{c}\text { RL- } \\
\text { WM05 } \\
\text { RL-ER05 }\end{array}$ & $\begin{array}{l}\text { RL-ER06 } \\
\text { RL-ER07 }\end{array}$ \\
\hline 307 Retention Basins & $\begin{array}{l}\text { RL- } \\
\text { WM05 }\end{array}$ & -- & -- & -- & 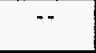 & - & RL-WM05 & -- & $\begin{array}{l}\text { RL-ER06 } \\
\text { RL-ER07 }\end{array}$ \\
\hline Fast Flux Test Facility & RL-TPI1 & - & $\cdots$ &.- & - & -- & RL-TPII & $\begin{array}{l}\text { RL-TP11 } \\
\text { RL-ER05 } \\
\end{array}$ & $\begin{array}{l}\text { RL-ER06 } \\
\text { RL-ER07 } \\
\end{array}$ \\
\hline $\begin{array}{l}300 \text { Area Fuel Supply } \\
\text { System }\end{array}$ & RL-TP04 & -- & $\cdots$ & $\cdots$ & -- & $\cdots$ & $\cdots$ & $\begin{array}{l}\text { RL-TP04 } \\
\text { RL-ER05 } \\
\end{array}$ & $\begin{array}{l}\text { RL-ER06 } \\
\text { RL-ER07 } \\
\end{array}$ \\
\hline 308 Building & RL-ER05 & -- & + & $\cdots$ & $\cdots$ & $\cdots$ & $\cdots$ & RL-EROS & $\begin{array}{l}\text { RI-ER06 } \\
\text { RI-ER07 } \\
\end{array}$ \\
\hline 309 Building & RL-TP11 & -- & $\cdots$ & $\cdots$ & $\cdots$ & $\cdots$ & $\because$ & $\begin{array}{l}\text { RL-ER05 } \\
\text { RL-TP11 }\end{array}$ & RI-ER06 \\
\hline 336 & RL_ST01 & -- & $\cdots$ & $\cdots$ & $\cdots$ & $\cdots$ & $\cdots$ & 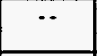 & $\begin{array}{l}\text { RI-ER06 } \\
\text { RI_ER07 }\end{array}$ \\
\hline 338 & RL-ST01 & $\cdots$ & - & $\cdots$ & $\cdots$ & $\cdots$ & RL-STO1 & $\cdots$ & $\begin{array}{l}\text { RI-ER06 } \\
\text { RI-ER07 }\end{array}$ \\
\hline 324 Building & RL-TP08 & -- & -- & $\cdots$ & $\ldots$ & $\cdots$ & $\begin{array}{l}\text { RL-TP08 } \\
\text { RL-ST01 }\end{array}$ & $\begin{array}{l}\text { RL-TP08 } \\
\text { RL_ER05 }\end{array}$ & $\begin{array}{l}\text { RL_ER06 } \\
\text { RL_ER07 }\end{array}$ \\
\hline 325 Building & RL-ST01 & $\cdots$ & 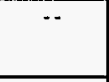 & - & -- & -- & $\begin{array}{c}\text { RL-ST01 } \\
\text { RL-ST02- } \\
09\end{array}$ & $\begin{array}{l}\text { RL-TP14 } \\
\text { RL-ER05 }\end{array}$ & $\begin{array}{l}\text { RL-ER06 } \\
\text { RL-ER07 }\end{array}$ \\
\hline 326 Building & RL-ER10 & -- & - & $\cdots$ & $\cdots$ & $\cdots$ & RL-STO1 & $\begin{array}{l}\text { RL-TP14 } \\
\text { RL-ER05 }\end{array}$ & $\begin{array}{l}\text { RL-ER06 } \\
\text { RL-ER07 }\end{array}$ \\
\hline 327 Building & RL-TP08 & $\cdots$ & $\cdots$ & -- & -- & -- & $\begin{array}{l}\text { RL-TP08 } \\
\text { RL-ST01 } \\
\end{array}$ & $\begin{array}{l}\text { RL-TP08 } \\
\text { RL-ER05 }\end{array}$ & $\begin{array}{l}\text { RL-ER06 } \\
\text { RL-ER07 }\end{array}$ \\
\hline 329 Building & RL_ST01 & $\ldots$ & -- & -- & - & $\cdots$ & RL-ST01 & $\begin{array}{l}\text { RL-TP14 } \\
\text { RL-ER05 } \\
\end{array}$ & $\begin{array}{l}\text { RL-ER06 } \\
\text { RL_ER07 } \\
\end{array}$ \\
\hline $306 \mathrm{~W}$ & RL-ST01 & - & -- & -- & -- & -- & $\begin{array}{c}\text { RL-ST01 } \\
\text { RL-ST02- } \\
09 \\
\end{array}$ & $\begin{array}{l}\text { RL-TP14 } \\
\text { RL-ER05 }\end{array}$ & $\begin{array}{l}\text { RL-ER06 } \\
\text { RL-ER07 }\end{array}$ \\
\hline 318 & RL-ST01 & - & - & $\cdots$ & $\cdots$ & $*$ & $\begin{array}{c}\text { RL-ST01 } \\
\text { RL-ST02- } \\
09\end{array}$ & - & $\begin{array}{l}\text { RI-ER06 } \\
\text { RL-ER07 }\end{array}$ \\
\hline $320 / 3720 / 3745$ & RL-STO1 & $\cdots$ & $\cdots$ & $\therefore$ & $\because$ & -- & $\begin{array}{l}\text { RL-ST01 } \\
\text { RL-ST02- } \\
09\end{array}$ & $\begin{array}{l}\text { RL-TP14 } \\
\text { RL-ER05 }\end{array}$ & $\begin{array}{l}\text { RL-ER06 } \\
\text { RL-ER07 }\end{array}$ \\
\hline Misc. Rad Labs & RI-ER10 & -- & -- & -- & -- & -- & -- & $\begin{array}{l}\text { RL-TP14 } \\
\text { RL-ER05 }\end{array}$ & $\begin{array}{l}\text { RL-ER06 } \\
\text { RL-ER07 }\end{array}$ \\
\hline 331 Complex & RL-ER10 & $\cdots$ & $\cdots$ & $\cdots$ & $\cdots$ & $\cdots$ & $\begin{array}{c}\text { RL-ST01 } \\
\text { RL-ST02- } \\
09\end{array}$ & $\begin{array}{l}\text { RL-TP14 } \\
\text { RL-ER05 }\end{array}$ & $\begin{array}{l}\text { RL-ER06 } \\
\text { RL_ER07 }\end{array}$ \\
\hline
\end{tabular}

D\&D = decontamination and decommissioning

WRAP $=$ Waste Receiving and Processing 
DOE/RL-97-55

Revision 0

February 2, 1998

4.3.5.5 Project Safety Authorization Basis/NEPA and Permits. The ER Project has prepared and will maintain BHI-00981, ERC Hazard Classification Matrices for Above Ground Structures and Groundwater and Soil Remediation Activities (Curry 1997), which provides the status of preliminary hazards classification process for the ER Project. This classification process is based on current $\mathrm{DOE}$ guidance for the classification of facilities and activities containing radionuclide and nonradiological hazardous material inventories.

4.3.5.6 Other Requirements and Planning Assumptions. The S\&M Project will comply with the requirements and milestones of the Tri-Party Agreement.

4.3.5.7 Interfaces. The S\&M Project's primary interface is with the 100 Area, 200 Area, and 300 Area Remedial Action and D\&D Projects for coordination of S\&M and radiation area remedial action with the remedial action and decommissioning activities. Additionally, the S\&M Project interfaces with EM-60; U.S. Department of Energy, Office of Site Operations (EM-70); and EM-30 for transition of inactive facilities.

The Waste Management Program will provide solid waste, liquid waste, and analytical laboratory support.

4.3.5.8 Logic Diagram. Refer to Figure 4-9.

4.3.5.9 Requirements References. None.

\subsubsection{Planning Assumptions.}

- S\&M will be required until the facilities are decommissioned and the waste sites are remediated.

- S\&M for facilities being transitioned to EM-40 will require additional funding.

- Resources, including labor, analytical capabilities, equipment, and general infrastructure, will be available when required.

\subsubsection{D\&D Project}

The contractor shall provide the M\&I of decontamination and decommissioning of facilities assigned to the ER Project. The facilities are located throughout the Hanford Site.

The D\&D Project responsibilities include the following:

- Managing and integrating the decontamination and decommissioning of inactive facilities assigned to the ER Project 
DOE/RL-97-55

Revision 0

February 2, 1998

- Managing and integrating the interim safe storage and final disposition of the surplus reactors.

4.3.6.1 Project Description Summary. The Hanford Site contains many surplus facilities remaining from $\mathrm{Pu}$ production activities that were required by the U.S. Department of Defense from World War II through the Cold War. Those facilities are now aged and deteriorating. Because the facilities have no production mission, they must be either maintained (to preserve their integrity) or removed to (1) preclude the escape of potentially hazardous substances into the accessible environment, and (2) eliminate unacceptably hazardous conditions for the workers who must maintain them.

The primary objective of the D\&D Project is to eliminate potential environmental, human health, and safety hazards by dispositioning the surplus, inactive facilities at the Hanford Site. The D\&D efforts at the Hanford Site will proceed on a priority-based path that results in an expedient and cost-efficient transition of facilities to a safe and stable condition (including demolition) that presents no significant threat of release of hazardous substances to the environment, and no significant risk to human health.

The D\&D Project is organizationally a standalone project in the overall ER Project.

4.3.6.2 Geographic Requirements/Assumptions. The D\&D Project will support the goals and end states for the areas of the Hanford Site that are referenced in the Hanford Strategic Plan (RL 1996c) as the Reactors on the River, the Central Plateau, and the South 600 Area.

\section{Reactors on the River}

Goal: Remove and/or stabilize SNF, surplus facilities, and waste sites to protect groundwater and the Columbia River, and ensure protection of people, the environment, and natural and cultural resources. Pending Congressional action on the Wild and Scenic River designation, use will continue to be restricted; sensitive ecological, cultural, and Native American resources will be protected.

Facilities End State:

- Reactors placed in interim safe storage for up to 75 years pending future removal

- Reactor blocks transported to Central Plateau for disposal

- Removal of non-essential, surplus buildings and facilities that do not have identified post-cleanup uses.

\section{Central Plateau}

Goal: The 200 Areas and Central Plateau will be used for the management of NM, for the collection and disposal of waste materials that remain onsite, and for other related and compatible 
DOE/RL-97-55

Revision 0

February 2, 1998

uses. Cleanup levels and disposal standards will be established that are consistent with these long-term uses.

Facilities End State:

- Dismantle, or close through entombment, D\&D facilities currently assigned to the ER Program.

- Remove non-essential, surplus buildings and facilities that do not have identified post-cleanup uses.

\section{South 600 Area}

Goal: The 300 Area waste sites, materials, and facilities will be remediated to allow industrial and economic diversification opportunities. The federal government will retain ownership of land in and adjacent to the 300 and 400 Areas, but will lease land for private and public uses to support regional industrial and economic development. Excess land within the 1100 Area will be targeted for transition to non-federal ownership.

Facilities End State:

- Reuse facilities for economic diversification where feasible.

- Remove non-essential, surplus buildings and facilities that do not have identified postcleanup uses.

4.3.6.3 Material and Waste Flow Requirements/Assumptions. The D\&D Project will achieve cleanup goals through decontamination in conjunction with demolition and/or entombment of facilities. The wastes generated through the D\&D Project will be disposed in the ERDF.

4.3.6.4 Facility Life-Cycle Requirements/Assumptions. The following table identifies the D\&D Project facility responsibilities. The life-cycle phases are those identified in DOE Order 430.1, Life-Cycle Asset Management (DOE 1995c).

\begin{tabular}{|c|c|c|c|c|c|c|c|c|c|}
\hline \multirow{3}{*}{ Major facility } & \multicolumn{9}{|c|}{ Life cycle } \\
\hline & \multirow{2}{*}{$\begin{array}{l}\text { Program } \\
\text { planning }\end{array}$} & \multirow{2}{*}{$\begin{array}{c}\text { Pre- } \\
\text { conceptual }\end{array}$} & \multirow[b]{2}{*}{ Conceptual } & \multicolumn{3}{|c|}{ Execute } & \multirow{2}{*}{$\begin{array}{l}\text { Ops and } \\
\text { maint }\end{array}$} & \multicolumn{2}{|c|}{ Close out } \\
\hline & & & & Design & Construct & Turnover & & $\begin{array}{c}\text { Post- } \\
\text { operation }\end{array}$ & $D \& D$ \\
\hline 100 K Area Facilities & $\begin{array}{c}\text { RL-WM01 } \\
\text { RL-TP09 }\end{array}$ & $\cdots$ & 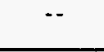 & - & -- & -- & $\begin{array}{c}\mathrm{RI} \\
\mathrm{WM} \\
\text { WM1 }\end{array}$ & $\begin{array}{l}\text { RL-TP09 } \\
\text { RL-ER05 }\end{array}$ & $\begin{array}{l}\text { RL-ER06 } \\
\text { RL-ER07 }\end{array}$ \\
\hline 242-A Evaporator & RL-WM0S & $\cdots$ & $\cdots$ & $\therefore$ & $\cdots$ & $\cdots$ & $\underset{\text { WM05 }}{\text { RL- }}$ & $\begin{array}{l}\text { RL-TP10 } \\
\text { RL-ER05 }\end{array}$ & $\begin{array}{l}\text { RL-ER06 } \\
\text { RL_ER07 }\end{array}$ \\
\hline $\begin{array}{l}\text { Plutonium-Uranium } \\
\text { Extraction Plant }\end{array}$ & RL-TP03 & $\cdots$ & $\cdots$ & -- & - & - & $=$ & $\begin{array}{l}\text { RL-TP03 } \\
\text { RL-ER05 }\end{array}$ & $\begin{array}{l}\text { RL-ER06 } \\
\text { RL-ER07 }\end{array}$ \\
\hline B Plant & RL-TP01 & -- & - & $\cdots$ & $\cdots$ & $\cdots$ & $\cdots$ & $\begin{array}{l}\text { RL-TPOI } \\
\text { RL-EROS }\end{array}$ & $\begin{array}{l}\text { RL-ER06 } \\
\text { RL-ER07 }\end{array}$ \\
\hline $\begin{array}{l}\text { Waste Encapsulation } \\
\text { and Storage Facility }\end{array}$ & RL-TP02 & -- & - & - & $\cdots$ & $\cdots$ & RL-TPO2 & $\begin{array}{l}\text { RL_TP02 } \\
\text { RL_ER05 }\end{array}$ & $\begin{array}{l}\text { RL-ER06 } \\
\text { RL-ER07 }\end{array}$ \\
\hline
\end{tabular}


DOE/RL-97-55

Revision 0

February 2, 1998

\begin{tabular}{|c|c|c|c|c|c|c|c|c|c|}
\hline \multirow{3}{*}{ Major facility } & \multicolumn{9}{|c|}{ Life cycle } \\
\hline & \multirow{2}{*}{$\begin{array}{l}\text { Program } \\
\text { planning }\end{array}$} & \multirow{2}{*}{$\begin{array}{c}\text { Pre- } \\
\text { conceptual }\end{array}$} & \multirow[b]{2}{*}{ Conceptual } & \multicolumn{3}{|c|}{ Execute } & \multirow{2}{*}{$\begin{array}{l}\text { Ops and } \\
\text { maint }\end{array}$} & \multicolumn{2}{|c|}{ Close out } \\
\hline & & & & Design & Construct & Tumover & & $\begin{array}{c}\text { Post- } \\
\text { operation }\end{array}$ & $\mathrm{D} \& \mathrm{D}$ \\
\hline $\begin{array}{l}\text { Plutonium Finishing } \\
\text { Plant }\end{array}$ & RL-TP07 & -. & -- & -- & $\cdots$ & $-\cdot$ & $\begin{array}{l}\text { RL-TP07 } \\
\text { RL-TP05 } \\
\text { RL-TP06 }\end{array}$ & $\begin{array}{l}\text { RL-TP07 } \\
\text { RL-ER05 } \\
\text { RL-TP05 } \\
\text { RL-TP06 } \\
\end{array}$ & $\begin{array}{l}\text { RL-ER06 } \\
\text { RL-ER07 } \\
\end{array}$ \\
\hline $\begin{array}{l}\text { Reduction-Oxidation } \\
\text { Plant }\end{array}$ & RL-ER02 & -- & $\cdots$ & -- & $\cdots$ & -. & -- & RL-EROS & $\begin{array}{l}\text { RL-ER06 } \\
\text { RL-ER07 } \\
\end{array}$ \\
\hline Uranium Oxide Plant & RL-ER02 & -- & $\because$ & -- & $\cdots$ & $\cdots$ & -- & RL-ER05 & $\begin{array}{l}\text { RL-ER06 } \\
\text { RL-ER07 }\end{array}$ \\
\hline I Plant Facility & RL-WMO4 & $\cdots$ & -. & $\cdots$ & -- & -- & $\begin{array}{l}\text { RL- } \\
\text { WM04 }\end{array}$ & $\begin{array}{c}\text { RL-TP10 } \\
\text { RL-ER05 } \\
\text { RL-WM04 }\end{array}$ & $\begin{array}{l}\text { RL-ER06 } \\
\text { RL-ER07 }\end{array}$ \\
\hline $2706-T$ & RL-WMO4 & $\cdots$ & -- & $-\cdot$ & -- & -- & $\underset{\text { WM04 }}{\text { RL- }}$ & \begin{tabular}{|c|} 
RL-TP10 \\
RL-ER05 \\
RL-WM04
\end{tabular} & $\begin{array}{l}\text { RL-ER06 } \\
\text { RL-ER07 }\end{array}$ \\
\hline $\begin{array}{l}200 \text { Ares Effluent } \\
\text { Treatment Facility }\end{array}$ & RL-WMOS & $\cdots$ & -- & - & -. & -- & $\begin{array}{l}\text { RL- } \\
\text { WM05 }\end{array}$ & $\begin{array}{l}\text { RL-TP10 } \\
\text { RL-ER05 }\end{array}$ & $\begin{array}{l}\text { RL-ER06 } \\
\text { RL-ER07 } \\
\end{array}$ \\
\hline $\begin{array}{l}\text { Central Waste } \\
\text { Complex }\end{array}$ & RL-WM03 & - & $-\cdot$ & $\cdots$ & -- & $\cdots$ & $\begin{array}{c}\mathrm{RL} \\
\mathrm{WMO3}\end{array}$ & $\begin{array}{c}\text { RL- } \\
\text { WM03 }\end{array}$ & $\begin{array}{l}\text { RL-ER06 } \\
\text { RL-ER07 } \\
\end{array}$ \\
\hline $\begin{array}{l}\text { Nonradioactive } \\
\text { Pangerous Waste } \\
\text { Storage Facility }\end{array}$ & RL-WM03 & -- & $\cdots$ & -- & $\cdots$ & -- & -- & $\begin{array}{l}\mathrm{RL} \\
\mathrm{WM} 03\end{array}$ & $\begin{array}{l}\text { RL-ER06 } \\
\text { RL-ER07 }\end{array}$ \\
\hline $\begin{array}{l}\text { Liquid Effluent } \\
\text { Retention Facility }\end{array}$ & RL-WMOS & $\cdots$ & -- & $\cdots$ & -- & -- & $\begin{array}{c}\text { RL- } \\
\text { WM05 }\end{array}$ & $\begin{array}{l}R L-T P 10 \\
\text { RL-ER05 } \\
\end{array}$ & $\begin{array}{l}\text { RL-ER06 } \\
\text { RL-ER07 }\end{array}$ \\
\hline $\begin{array}{l}\text { Transuranic Storage } \\
\text { and Assay Facility }\end{array}$ & RL-WM03 & -. & -- & -- & $\because$ & -- & $\begin{array}{l}\text { RI } \\
\text { WM03 }\end{array}$ & $\begin{array}{c}\text { RL-TP10 } \\
\text { RL-ER05 } \\
\text { RL-WM03 }\end{array}$ & $\begin{array}{l}\text { RL-ER06 } \\
\text { RL-ER07 }\end{array}$ \\
\hline 222-S Laboratory & RL-WM06 & $\cdots$ & -- & $\cdot-$ & -- & -. & $\begin{array}{l}\text { RL } \\
\text { WM06 }\end{array}$ & \begin{tabular}{|c|} 
RL-TP10 \\
RL-ER05 \\
RL-WM03
\end{tabular} & $\begin{array}{l}\text { RL-ER06 } \\
\text { RL-ER07 }\end{array}$ \\
\hline $\begin{array}{l}\text { Waste Sampling and } \\
\text { Characterization } \\
\text { Facility }\end{array}$ & RL-WM06 & -. & -- & $\cdots$ & $-\cdot$ & $\cdots$ & $\stackrel{\text { RL }}{\text { WM06 }}$ & $\begin{array}{c}\text { RL- } \\
\text { WM06 }\end{array}$ & $\begin{array}{l}\text { RL-ER06 } \\
\text { RL-ER07 }\end{array}$ \\
\hline $\begin{array}{l}340 \text { Waste Handling } \\
\text { Facility }\end{array}$ & RL-WM05 & -- & - & -- & $\cdots$ & -- & $\begin{array}{l}\text { RL- } \\
\text { WM05 }\end{array}$ & $\begin{array}{c}\text { RL- } \\
\text { WM05 } \\
\text { RL-ER05 }\end{array}$ & $\begin{array}{l}\text { RL-ER06 } \\
\text { RL-ER07 }\end{array}$ \\
\hline 307 Retention Basins & RL-WM05 & -- & $\cdots$ & -- & $\cdots$ & - & $\begin{array}{c}\text { RL } \\
\text { WMOS }\end{array}$ & $\cdots$ & $\begin{array}{l}\text { RL-ER06 } \\
\text { RL-ER07 }\end{array}$ \\
\hline Fast Flux Test Facility & RL-TP11 & -- & -- & $\cdots$ & $\cdots$ & $\cdots$ & RL-TP1I & $\begin{array}{l}\text { RL-TP11 } \\
\text { RL-ER05 } \\
\end{array}$ & $\begin{array}{l}\text { RL-ER06 } \\
\text { RL-ER07 } \\
\end{array}$ \\
\hline $\begin{array}{l}300 \text { Area Fuel Supply } \\
\text { System }\end{array}$ & RL-TP04 & -- & $\cdots$ & -- & $\cdots$ & $\cdots$ & -- & $\begin{array}{l}\text { RL-TP04 } \\
\text { RL-ER05 }\end{array}$ & $\begin{array}{l}\text { RL-ER06 } \\
\text { RL-ER07 }\end{array}$ \\
\hline 308 Building & RL-ER05 & $\cdots$ & $\cdots$ & -- & -- & $\cdots$ & $-\cdot$ & RL-ER05 & $\begin{array}{l}\text { RL-ER06 } \\
\text { RL-ER07 }\end{array}$ \\
\hline 309 Building & RL-TP11 & -- & $\cdots$ & -- & $\cdots$ & $\cdot-$ & -. & $\begin{array}{l}\text { RL-TP11 } \\
\text { RL-ER05 } \\
\end{array}$ & RL-ER06 \\
\hline 336 & RL-ST01 & $-\cdot$ & -- & -- & $\cdots$ & -- & -- & $\cdots$ & $\begin{array}{l}\text { RL-ER06 } \\
\text { RL-ER07 } \\
\end{array}$ \\
\hline 338 & RL-ST01 & $\cdot \cdot$ & $\cdots$ & $\cdots$ & $-\cdot$ & $\cdots$ & RL-ST01 & $\cdots$ & $\begin{array}{l}\text { RL-ER06 } \\
\text { RL-ER07 } \\
\end{array}$ \\
\hline 324 Building & RL-TP08 & $\cdots$ & -. & -- & -. & -- & $\begin{array}{l}\text { RL-TP08 } \\
\text { RL-ST01 }\end{array}$ & $\begin{array}{l}\text { RL-TP08 } \\
\text { RL-ER05 }\end{array}$ & $\begin{array}{l}\text { RL-ER06 } \\
\text { RL-ER07 }\end{array}$ \\
\hline
\end{tabular}


DOE/RL-97-55

Revision 0

February 2, 1998

\begin{tabular}{|c|c|c|c|c|c|c|c|c|c|}
\hline \multirow{3}{*}{ Major facility } & \multicolumn{9}{|c|}{ Life cycle } \\
\hline & \multirow{2}{*}{$\begin{array}{l}\text { Program } \\
\text { planning }\end{array}$} & \multirow{2}{*}{$\begin{array}{c}\text { Pre- } \\
\text { conceptual }\end{array}$} & \multirow[b]{2}{*}{ Conceptual } & \multicolumn{3}{|c|}{ Execute } & \multirow[b]{2}{*}{$\begin{array}{c}\text { Ops and } \\
\text { maint }\end{array}$} & \multicolumn{2}{|c|}{ Close out } \\
\hline & & & & Design & Construct & Turnover & & $\begin{array}{c}\begin{array}{c}\text { Post- } \\
\text { operation }\end{array} \\
\end{array}$ & D\&D \\
\hline 325 Building & RL-ST01 & $\cdots$ & -- & $\cdots$ & $\cdots$ & $\cdots$ & $\begin{array}{c}\text { RL_ST01 } \\
\text { RL-ST02- } \\
09 \\
\end{array}$ & \begin{tabular}{|l|} 
RL-TP14 \\
RL-ER05
\end{tabular} & $\begin{array}{l}\text { RL-ER06 } \\
\text { RL-ER07 }\end{array}$ \\
\hline 326 Building & RI-ER10 & $\therefore$ & -- & -- & $\cdots$ & -. & RLST01 & $\begin{array}{l}\text { RL-TP14 } \\
\text { RL-ER05 }\end{array}$ & $\begin{array}{l}\text { RL-ER06 } \\
\text { RL-ER07 }\end{array}$ \\
\hline 327 Building & RL-TP08 & - & -- & $\cdots$ & $\cdots$ & $\cdots$ & \begin{tabular}{|l|} 
RL-TP08 \\
RL-ST01 \\
\end{tabular} & $\begin{array}{l}\text { RL-TP08 } \\
\text { RL-ER05 } \\
\end{array}$ & $\begin{array}{l}\text { RL-ER06 } \\
\text { RL-ER07 }\end{array}$ \\
\hline 329 Building & RL-ST01 & -- & - & - & $\cdots$ & -- & RL-STOI & $\begin{array}{l}\text { RL-TP14 } \\
\text { RL-ER05 } \\
\end{array}$ & $\begin{array}{l}\text { RL-ER06 } \\
\text { RL-ER07 }\end{array}$ \\
\hline $306 \mathrm{~W}$ & RL-ST01 & $\cdots$ & -- & -- & -- & $\cdots$ & \begin{tabular}{|c|} 
RL_ST01 \\
RL-ST02- \\
09 \\
\end{tabular} & $\begin{array}{l}\text { RL-TP14 } \\
\text { RL-ER05 }\end{array}$ & $\begin{array}{l}\text { RL-ER06 } \\
\text { RL-ER07 }\end{array}$ \\
\hline 318 & RL-ST01 & $\cdots$ & - & -- & $\cdots$ & $\cdots$ & $\begin{array}{c}\text { RL-ST01 } \\
\text { RL-ST02- } \\
09 \\
\end{array}$ & -. & $\begin{array}{l}\text { RL-ER06 } \\
\text { RL-ER07 }\end{array}$ \\
\hline $320 / 3720 / 3745$ & RL-ST01 & $\cdots$ & - & $\cdots$ & $\cdots$ & -- & \begin{tabular}{|c|} 
RL-ST01 \\
RL-ST02- \\
09 \\
\end{tabular} & $\begin{array}{l}\text { RL-TP14 } \\
\text { RL-ER05 }\end{array}$ & $\begin{array}{l}\text { RL-ER06 } \\
\text { RL-ER07 }\end{array}$ \\
\hline Misc. Rad Labs & RL-ER10 & $\cdots$ & $\cdots$ & -- & -. & $\cdots$ & -- & $\begin{array}{l}\text { RL-TP14 } \\
\text { RL-ER05 } \\
\end{array}$ & $\begin{array}{l}\text { RL-ER06 } \\
\text { RLLER07 } \\
\end{array}$ \\
\hline 331 Complex & RL-ERIO & $\cdots$ & $\cdots$ & -- & -- & -- & $\begin{array}{c}\text { RL-ST01 } \\
\text { RL-ST02- } \\
09\end{array}$ & $\begin{array}{l}\text { RL-TP14 } \\
\text { RL-ER05 }\end{array}$ & $\begin{array}{l}\text { RL-ER06 } \\
\text { RL-ER07 }\end{array}$ \\
\hline
\end{tabular}

$\mathrm{D} \& \mathrm{D}=$ decontamination and decommissioning

4.3.6.5 Project Safety Authorization Basis/NEPA and Permits. The ER Project has prepared and will maintain BHI-00981, ERC Hazard Classification Matrices for Above Ground Structures and Groundwater and Soil Remediation Activities (Curry 1997), which provides the status of preliminary hazards classification process for the ER Project. This classification process is based on current DOE guidance for the classification of facilities and activities containing radionuclide and nonradiological hazardous material inventories.

4.3.6.6 Other Requirements and Planning Assumptions. The D\&D Project will comply with the requirements and milestones of the Tri-Party Agreement.

4.3.6.7 Interfaces. The D\&D Project's primary interface is with the 100 Area, 200 Area, and 300 Area Remedial Action and S\&M Projects for coordination of D\&D with the remedial action and $\mathrm{S} \& \mathrm{M}$ activities.

The Waste Management Program will provide solid waste, liquid waste, and analytical laboratory support.

4.3.6.8 Logic Diagram. Refer to Figure 4-9.

4.3.6.9 Requirements References. None. 
DOE/RL-97-55

Revision 0

February 2, 1998

\subsubsection{Planning Assumptions.}

- Reactors will placed in interim safe storage for up to $\mathbf{7 5}$ years pending future removal.

- Reactor blocks will be transported to the Central Plateau for disposal.

- Non-essential, surplus buildings and facilities that do not have identified post-cleanup uses will be removed.

- Facilities will be reused for economic diversification, where feasible.

- The 200 Area facilities, with exception of the canyon facilities, will be removed. The canyon facilities will be partially demolished and entombed in place.

- Non-contaminated foundations $0.9 \mathrm{~m}$ below grade will be left in place.

- Decontamination and decommissioning of facilities being transitioned to EM-40 will require additional funding.

- Resources, including labor, analytical capabilities, equipment, and general infrastructure, will be available when required.

\subsubsection{Long-Term S\&M Project}

The contractor shall provide the M\&I of long-term surveillance and maintenance of waste sites after completion of remediation and of the facilities after completion of D\&D. The waste sites and facilities are located throughout the Hanford Site.

Long-Term S\&M Project responsibilities include the following:

- Managing and integrating the long-term S\&M of the completed waste sites and facilities

- Managing and integrating the transition within and to the ER Project of completed waste sites and facilities at the Hanford Site.

4.3.7.1 Project Description Summary. Upon completion of remediation of contaminated waste sites and/or surplus facilities, the areas will be restored to support future land uses. Site restoration will consist mainly of site contouring and revegetation efforts to stabilize the sites. Where appropriate, the sites will use seeds from local species for revegetation efforts. Upon completion of the revegetation efforts, the sites will enter the long-term S\&M for monitoring the success of the revegetation efforts. Any revegetation efforts subsequent to those conducted at the end of remediation will be conducted in long-term S\&M. 
Currently, the Long-Term S\&M Project is organizationally part of the S\&M Project in the overall ER Project.

4.3.7.2 Geographic Requirements/Assumptions. The Long-Term S\&M Project will support the goals and end states for all areas of the Hanford Site.

4.3.7.3 Material and Waste Flow Requirements/Assumptions. The Long-Term S\&M Project should not produce any waste quantities.

4.3.7.4 Facility Life-Cycle Requirements/Assumptions. The following table identifies the Long-Term S\&M Project facility and operable unit responsibilities. The life-cycle phases are those identified in DOE Order 430.1, Life-Cycle Asset Management (DOE 1995c). Long-term S\&M is included in the D\&D phase.

\begin{tabular}{|c|c|c|c|c|c|c|c|c|c|}
\hline \multirow{3}{*}{ Major facility } & \multicolumn{9}{|c|}{ Life cycle } \\
\hline & \multirow{2}{*}{$\begin{array}{l}\text { Program } \\
\text { planning }\end{array}$} & \multirow[b]{2}{*}{ Preconceptual } & \multirow[b]{2}{*}{ Conceptual } & \multicolumn{3}{|c|}{ Execute } & \multirow{2}{*}{$\begin{array}{c}\text { Ops and } \\
\text { maint }\end{array}$} & \multicolumn{2}{|c|}{ Close out } \\
\hline & & & & Design & Construct & Turnover & & $\begin{array}{c}\text { Post- } \\
\text { operation }\end{array}$ & $D \& D$ \\
\hline $\begin{array}{l}\text { Reactors on the } \\
\text { River Groundwater } \\
\text { Operable Units }\end{array}$ & RL-ER10 & -- & $\cdot-$ & -- & -. & $\cdots$ & $\cdot-$ & RL-ER08 & $\begin{array}{l}\text { RL-ER08 } \\
\text { RL-ER07 }\end{array}$ \\
\hline $\begin{array}{l}\text { Reactors on the } \\
\text { River Soil Site } \\
\text { Operable Units }\end{array}$ & RL-ER10 & - & $\cdots$ & - & -- & $\cdots$ & -- & $\begin{array}{l}\text { RL-ER01 } \\
\text { RL-ER05 }\end{array}$ & $\begin{array}{l}\text { RL-ER01 } \\
\text { RL-ER07 } \\
\text { RL-ER09 }\end{array}$ \\
\hline $\begin{array}{l}\text { Central Plateau } \\
\text { Groundwater } \\
\text { Operable Units }\end{array}$ & RL-ER 10 & - & $\cdots$ & -- & -- & - & -- & RL-ER08 & $\begin{array}{l}\text { RL-ER08 } \\
\text { RL-ER07 }\end{array}$ \\
\hline $\begin{array}{l}\text { Central Plateau Soil } \\
\text { Site Operable Units }\end{array}$ & RL-ER10 & -- & -- & -- & - & - & - & $\begin{array}{l}\text { RL-ER02 } \\
\text { RL-ER05 }\end{array}$ & $\begin{array}{l}\text { RL-ER02 } \\
\text { RL-ER07 }\end{array}$ \\
\hline $\begin{array}{l}\text { Central Core Site } \\
\text { Operable Units }\end{array}$ & RL-ER10 & $\cdots$ & $\cdots$ & $\cdots$ & $-\cdot$ & -- & $\cdots$ & RL-ER02 & $\begin{array}{l}\text { RL-ER02 } \\
\text { RL-ER07 }\end{array}$ \\
\hline $\begin{array}{l}\text { South } 600 \text { Area } \\
\text { Groundwater } \\
\text { Operable Units }\end{array}$ & RL-ER10 & -- & $\cdots$ & -- & $\cdots$ & - & -- & RL-ER08 & $\begin{array}{l}\text { RL-ER08 } \\
\text { RL-ER07 }\end{array}$ \\
\hline $\begin{array}{l}\text { South } 600 \text { Area Soil } \\
\text { Site Operable Units }\end{array}$ & RL-ER10 & - & -- & -. & - & $\cdots$ & $\cdots$ & $\begin{array}{l}\text { RL-ER08 } \\
\text { RL-ER05 }\end{array}$ & $\begin{array}{l}\text { RL-ER03 } \\
\text { RL-ER07 }\end{array}$ \\
\hline
\end{tabular}

$\mathrm{D} \& \mathrm{D}=$ decontamination and decommissioning

4.3.7.5 Project Safety Authorization Basis/NEPA and Permits. The ER Project has prepared and will maintain BHI-00981, ERC Hazard Classification Matrices for Above Ground Structures and Groundwater and Soil Remediation Activities (Curry 1997), which provides the status of preliminary hazards classification process for the ER Project. This classification process is based on current DOE guidance for the classification of facilities and activities containing radionuclide and nonradiological hazardous material inventories.

4.3.7.6 Other Requirements and Planning Assumptions. The Long-Term S\&M Project will comply with the requirements and milestones of the Tri-Party Agreement. 
4.3.7.7 Interfaces. The Long-Term S\&M Project's primary interface is with the 100 Area, 200 Area, and 300 Area Remedial Action and D\&D Projects.

The Waste Management Program will provide solid waste, liquid waste, and analytical laboratory support.

4.3.7.8 Logic Diagram. Refer to Figure 4-9.

4.3.7.9 Requirements References. None.

4.3.7.10 Planning Assumptions. Revegetation and subsequent monitoring are required for remediated waste sites and decommissioned facilities.

\subsubsection{Groundwater Management Project}

The contractor shall provide the M\&I of groundwater management for the Hanford Site. The Groundwater Management Project responsibilities include the following:

- Assessing the groundwater to determine the type and extent of contamination such that a ROD for remediation of the groundwater can be prepared

- Preparing the remedial design and performing the remedial actions necessary to implement the ROD

- Managing and integrating the numerous groundwater monitoring requirements

- Managing and integrating the groundwater well maintenance and decommissioning.

Groundwater and Vadose Zone Integration. There is a heightened awareness of the potential for vadose zone contamination impacting the groundwater and requests from the regulators, stakeholders, and tribal nations to assess the cumulative impacts of all waste sources from the Hanford Site to the groundwater and the Columbia River. To effectively integrate the groundwater and vadose zone activities and implement the groundwater protection management plan's strategic approach, $R L$ has directed that the groundwater and vadose zone activities be managed as a project. This project is currently being planned and will remain part of the ER Project Groundwater Management activities until the plans are reviewed and approved.

4.3.8.1 Project Description Summary. The Columbia River crosses the northern portion of the Hanford Site and essentially forms the eastern boundary. Groundwater under the 100,200, and 300 Areas has been contaminated through discharge of waste liquids to cribs, ditches, trenches, ponds, french drains, and retention basins. Currently, approximately $85 \mathrm{mi}^{2}$ of groundwater exceed drinking water standards, and portions of this contaminated groundwater have reached the Columbia River. 
The overall goal of the Groundwater Management Project is to restore groundwater to its intended beneficial uses in terms of protection of human health and the environment. The strategy is to contain the spread of contamination and to reduce the mass of contamination in the major groundwater plumes.

Remediation of groundwater will generally consist of groundwater extraction, surface treatment, and reinjection to the aquifer. Along with remediation, the Groundwater Management Project will coordinate and perform the required groundwater monitoring and well decommissioning.

The Groundwater Management Project is organizationally a standalone project within the overall ER Project.

4.3.8.2 Geographic Requirements/Assumptions. The Groundwater Management Project will support the goals and end states for the areas of the Hanford Site referenced in the Hanford Strategic Plan (RL 1996c) as the Reactors on the River, the Central Plateau, the South 600 Area, and Central Core.

\section{Reactors on the River}

Goal: Remove and/or stabilize SNF, surplus facilities, and waste sites to protect groundwater and the Columbia River and to ensure protection of people, the environment, and natural and cultural resources. Pending Congressional action on the Wild and Scenic River designation, use will continue to be restricted; sensitive ecological, cultural, and Native American resources will be protected.

Groundwater End State: Groundwater use remains restricted for a yet-to-be-determined period; groundwater will be intercepted or contained to protect the Columbia River and the environment. Final cleanup levels will be established within individual RODs or permit modifications.

\section{Central Plateau}

Goal: The 200 Areas and Central Plateau will be used for the management of NM, the collection and disposal of waste materials that remain onsite, and for other related and compatible uses. Cleanup levels and disposal standards will be established that are consistent with these long-term uses.

Groundwater End State: Groundwater use remains restricted for a yet-to-be-determined period; groundwater will be intercepted or contained to within designated boundaries. Final cleanup levels will be established within individual RODs or permit modifications.

\section{South 600 Area}

Goal: The $\mathbf{3 0 0}$ Area waste sites, materials, and facilities will be remediated to allow industrial and economic diversification opportunities. The federal government will retain 
ownership of land in and adjacent to the 300 and 400 Areas, but will lease land for private and public uses to support regional industrial and economic development. Excess land within the 1100 Area will be targeted for transition to non-federal ownership.

Groundwater End State: Groundwater use remains restricted for a yet-to-be-determined period; existing site plumes will continue to be monitored. Final cleanup levels will be established within individual RODs or permit modifications.

\section{Central Core Area}

Goal: This area will remain in federal ownership consistent with safety analysis boundaries and continued waste management operations in the 200 Area. These areas will be available for other federal programs or leased for non-federal uses, consistent with appropriate recognition of cultural and ecosystem values.

Groundwater End State: Monitor existing groundwater site plumes; intercept or contain as necessary to protect the Columbia River. Groundwater use remains restricted for a yet-to-be-determined period. Final cleanup levels will be established within individual RODs or permit modifications.

\subsubsection{Material and Waste Flow Requirements/Assumptions. The Groundwater} Management Project will produce waste from the treatment of the groundwater. These wastes will be disposed of in the ERDF. The 200-UP groundwater will be treated in the 200 Area ETF. Wastes produced from the 200-UP groundwater also will be disposed of in the ERDF.

4.3.8.4 Facility Life-Cycle Requirements/Assumptions. The following table identifies lifecycle responsibility for the Groundwater Operable Units. The life-cycle phases are those identified in DOE Order 430.1, Life-Cycle Asset Management (DOE 1995c). Remedial actions have been included in the D\&D phase.

\begin{tabular}{|c|c|c|c|c|c|c|c|c|c|}
\hline \multirow{3}{*}{ Major facility } & \multicolumn{9}{|c|}{ Life cycle } \\
\hline & \multirow{2}{*}{$\begin{array}{l}\text { Program } \\
\text { planning }\end{array}$} & \multirow[b]{2}{*}{ Preconceptual } & \multirow[b]{2}{*}{ Conceptual } & \multicolumn{3}{|c|}{ Execute } & \multirow{2}{*}{$\begin{array}{c}\text { Ops and } \\
\text { maint }\end{array}$} & \multicolumn{2}{|c|}{ Close out } \\
\hline & & & & Design & Construct & Turnover & & $\begin{array}{c}\text { Post- } \\
\text { operation }\end{array}$ & D\&D \\
\hline $\begin{array}{l}\text { Reactors on the } \\
\text { River Groundwater } \\
\text { Operable Units }\end{array}$ & RL-ER10 & $\cdots$ & $\cdots$ & - & -- & $\cdots$ & $\cdots$ & RL-ER08 & $\begin{array}{l}\text { RL-ER08 } \\
\text { RL-ER07 }\end{array}$ \\
\hline \begin{tabular}{|l|} 
Central Plateau \\
Groundwater \\
Operable Units \\
\end{tabular} & RL-ER 10 & -. & -. & $\cdots$ & 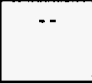 & $\cdots$ & -. & RL-ER0 8 & $\begin{array}{l}\text { RL-ER08 } \\
\text { RL-ER07 }\end{array}$ \\
\hline $\begin{array}{l}\text { South } 600 \text { Area } \\
\text { Groundwater } \\
\text { Operable Units }\end{array}$ & RL-ER10 & -- & $\cdots$ & $\cdots$ & $\cdots$ & $\because$ & $\cdots$ & RL-ER08 & $\begin{array}{l}\text { RL-ER08 } \\
\text { RL-ER07 }\end{array}$ \\
\hline
\end{tabular}

$\mathrm{D} \& \mathrm{D}=$ decontamination and decommissioning

4.3.8.5 Project Safety Authorization Basis/NEPA and Permits. The ER Project has prepared and will maintain BHI-00981, ERC Hazard Classification Matrices for Above Ground Structures and Groundwater and Soil Remediation Activities (Curry 1997), which provides the status of 
preliminary hazards classification process for the ER Project. This classification process is based on current DOE guidance for the classification of facilities and activities containing radionuclide and nonradiological hazardous material inventories.

4.3.8.6 Other Requirements and Planning Assumptions. The Groundwater Management Project will comply with the requirements and milestones of the Tri-Party Agreement.

4.3.8.7 Interfaces. The Groundwater Management Project primary interfaces are with the 100 Area, 200 Area, and 300 Area Remedial Action Projects, ERDF, and the 200 Area ETF.

The Waste Management Program will provide solid waste, liquid waste, and analytical laboratory support.

4.3.8.8 Logic Diagram. Refer to Figure 4-9.

4.3.8.9 Requirements References. None.

\subsubsection{Planning Assumptions.}

- Groundwater will be intercepted (or contained) to protect the Columbia River and the environment.

- Groundwater remediation activities beyond the initial interim actions of plume interception and plume containment will not be determined until final cleanup standards are established in individual RODs or permit modifications.

- Groundwater use remains restricted for a yet-to-be-determined period.

- The 100-HR-3 and 100-KR-4 pump and treat systems will operate through FY 2002.

- The 100-NR-2 pump and treat system will operate through FY 2011.

- The 200-ZP-1 pump and treat system will operate through FY 2002.

- The 200-UP-1 pump and treat system will operate through FY 1998.

- The 200-ZP-2 vapor extraction will operate on an interim basis through FY 2000.

\subsubsection{N Reactor Deactivation Project}

The contractor shall provide M\&I of the activities required to deactivate the N Reactor and its ancillary facilities. 
The N Reactor Deactivation Project is responsible for the following:

- Managing and integrating the deactivation of $\mathrm{N}$ Reactor and its ancillary facilities

- Meeting end point criteria required to transition N Reactor and its ancillary facilities to S\&M.

4.3.9.1 Project Description Summary. The N Reactor Deactivation Project involves the deactivation of 88 facilities, cleanout and stabilization of the $\mathrm{N}$ Basin, cleanout and stabilization of the Emergency Dump Basin, removal of fuel spacers from silos, operation of the $\mathrm{N}$ Reactor waste pad, and performance of S\&M.

The objective of the $\mathrm{N}$ Reactor Deactivation Project is to deactivate $\mathrm{N}$ Reactor by removing all unattached materials and equipment and to place the facilities in an environmentally safe condition such that minimal S\&M will be required.

The N Reactor Deactivation is a standalone project within the overall ER Project.

4.3.9.2 Geographic Requirements/Assumptions. The N Reactor Deactivation Project will support the goals and end states for the areas of the Hanford Site as referenced in the Hanford Strategic Plan (RL 1996c) as the Reactors on the River.

\section{Reactors on the River}

Goal: Remove and/or stabilize SNF, surplus facilities, and waste sites to protect groundwater and the Columbia River, and to ensure protection of people, the environment, and natural and cultural resources. Pending Congressional action on the Wild and Scenic River designation, use will continue to be restricted; sensitive ecological, cultural, and Native American resources will be protected.

Facilities End State:

- Reactors will be placed in interim safe storage for up to 75 years pending future removal. Reactor blocks will be transported to the Central Plateau for disposal.

- Non-essential, surplus buildings and facilities that do not have identified post-cleanup uses will be removed.

4.3.9.3 Material and Waste Flow Requirements/Assumptions. The $N$ Reactor Deactivation Project will dispose of most of the waste produced during deactivation in the ERDF. The water from the N Basin will be treated at the 200 Area ETF. Wastes created by this treatment will be disposed of in the ERDF. If SNF is discovered in the N Basin, the material will be transferred to the SNF Project for disposition.

4.3.9.4 Facility Life-Cycle Requirements/Assumptions. The following table identifies lifecycle responsibility for the $\mathrm{N}$ Reactor. The life-cycle phases are those identified in DOE Order 
DOE/RL-97-55

Revision 0

February 2, 1998

430.1, Life-Cycle Asset Management (DOE 1995c). S\&M is included in the post-operations phase.

\begin{tabular}{|c|c|c|c|c|c|c|c|c|c|}
\hline \multirow[b]{3}{*}{ Major facility } & \multicolumn{9}{|c|}{ Life cycle } \\
\hline & \multirow{2}{*}{$\begin{array}{l}\text { Program } \\
\text { planning }\end{array}$} & \multirow[b]{2}{*}{ Preconceptual } & \multirow[b]{2}{*}{ Conceptual } & \multicolumn{3}{|c|}{ Execute } & \multirow{2}{*}{$\begin{array}{c}\text { Ops and } \\
\text { maint }\end{array}$} & \multicolumn{2}{|c|}{ Close out } \\
\hline & & & & Design & Construct & Turnover & & $\begin{array}{c}\text { Post- } \\
\text { operation }\end{array}$ & $D \& D$ \\
\hline $\begin{array}{l}\text { Reactors on the } \\
\text { River Soil Site } \\
\text { Operable Units }\end{array}$ & RL-ER10 & -- & $\cdots$ & -- & -- & $\cdots$ & - & $\begin{array}{l}\text { RL_ER01 } \\
\text { RL_ER05 }\end{array}$ & $\begin{array}{l}\text { RI_ER01 } \\
\text { RL-ER07 } \\
\text { RL_ER09 }\end{array}$ \\
\hline
\end{tabular}

$\mathrm{D} \& \mathrm{D}=$ decontamination and decommissioning

4.3.9.5 Project Safety Authorization Basis/NEPA and Permits. The ER Project has prepared and will maintain BHI-00981, ERC Hazard Classification Matrices for Above Ground Structures and Groundwater and Soil Remediation Activities (Curry 1997), which provides the status of preliminary hazards classification process for the ER Project. This classification process is based on current DOE guidance for the classification of facilities and activities containing radionuclide and nonradiological hazardous material inventories.

4.3.9.6 Other Requirements and Planning Assumptions. The N Reactor Deactivation Project will comply with the requirements and milestones of the Tri-Party Agreement.

4.3.9.7 Interfaces. The $N$ Reactor Deactivation Project's primary interface is with the ER Waste Disposal Project for waste transportation and waste disposal and the S\&M Project for transition to S\&M. Additional interfaces are with the 200 Area ETF for treatment of the $\mathrm{N}$ Basin water, and a potential interface with the Spent Fuel Projects if spent fuel is discovered in the N Basin.

The Waste Management Program will provide solid waste, liquid waste, and analytical laboratory support.

4.3.9.8 Logic Diagram. Refer to Figure 4-9.

4.3.9.9 Requirements References.

- DOE/EA-0984, Environmental Assessment: Deactivation of N Reactor Facilities, Hanford Site, Richland, Washington (DOE 1995j).

\subsubsection{Planning Assumptions.}

- The wastes removed from the N Reactor will be disposed in the ERDF.

- N Basin water will be treated at the 200 Area ETF.

- Reactors will be placed in interim safe storage for up to 75 years, pending future removal. Reactor blocks will be transported to the Central Plateau for disposal. 
- Non-essential, surplus buildings and facilities that do not have identified post-cleanup uses will be removed.

\subsubsection{ER Project Management and Support}

The contractor shall provide the M\&I of the Program Management and Support activities for the ER Project. The contractor shall be responsible for the following:

- Management and integration within the ER Project and with the PHMC contractor.

4.3.10.1 Project Description Summary. The ER Project Management and Support provides the following:

- An overall quality program, including quality engineering and oversight

- Overall safety and health programs

- Environmental compliance programs

- Assessment and review of the implementation of these activities

- Overall management and implementation of technology applications, environmental sciences, regulatory support, and field services

- Development and maintenance of sample and data management systems

- Design engineering services

- Planning and integration

- Project controls and reporting

- Management and maintenance of cost and schedule control systems

- ERC Project performance measurement and administration

- Tri-Party Agreement support

- Public involvement and community relations

- Management and maintenance of procurement systems

- Management and maintenance of project records and document control 
- Ecology and CERCLA grants

- RL sitewide assessment, regulatory oversight, and independent cost estimating.

Additional areas of responsibility include the following:

- Overall management and implementation of technology applications, environmental sciences, cultural resources, and regulatory support; development and maintenance of sample and data management systems; enhancement of environmental cultural plans, guidance, policies and procedures; design engineering services

- Management and maintenance of procurement and document control systems

- Implementation of public involvement and community relations programs

- Management and maintenance of the cost/schedule control systems and project baseline; project reporting; planning and integration, ERC performance measurement and administration

- Overall quality/safety and health program development and oversight; environmental compliance program and independent assessment.

\subsubsection{Geographic Requirements/Assumptions. Not applicable.}

\subsubsection{Material and Waste Flow Requirements/Assumptions. Not applicable.}

\subsubsection{Facility Life-Cycle Requirements/Assumptions.}

\begin{tabular}{|c|c|c|c|c|c|c|c|c|c|}
\hline \multirow{3}{*}{ Major facility } & \multicolumn{9}{|c|}{ Life cycle } \\
\hline & \multirow[b]{2}{*}{$\begin{array}{l}\text { Program } \\
\text { planning }\end{array}$} & \multirow[b]{2}{*}{ Preconceptual } & \multirow[b]{2}{*}{ Conceptual } & \multicolumn{3}{|c|}{ Execute } & \multirow{2}{*}{$\begin{array}{l}\text { Ops and } \\
\text { maint }\end{array}$} & \multicolumn{2}{|c|}{ Close out } \\
\hline & & & & Design & Construct & Tumover & & $\begin{array}{c}\text { Post- } \\
\text { operation }\end{array}$ & D\&D \\
\hline $\begin{array}{l}\text { Reactors on the } \\
\text { River Groundwater } \\
\text { Operable Units }\end{array}$ & RL-ER10 & -- & $\cdots$ & $\cdots$ & - & - & $\cdots$ & RL-ER08 & $\begin{array}{l}\text { RL-ER08 } \\
\text { RL-ER07 }\end{array}$ \\
\hline $\begin{array}{l}\text { Reactors on the } \\
\text { River Soil Site } \\
\text { Operable Units }\end{array}$ & RL-ER10 & $\cdots$ & - & -- & 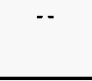 & $\cdots$ & - & $\begin{array}{l}\text { RL-ER01 } \\
\text { RL-ER05 }\end{array}$ & $\begin{array}{l}\text { RL-ER01 } \\
\text { RL-ER07 } \\
\text { RL-ER09 }\end{array}$ \\
\hline $\begin{array}{l}\text { Central Plateau } \\
\text { Groundwater } \\
\text { Operable Units } \\
\end{array}$ & RL-ER10 & -- & $\cdots$ & $\cdots$ & -- & -- & $\cdots$ & RL-ER08 & $\begin{array}{l}\text { RL-ER08 } \\
\text { RL-ER07 }\end{array}$ \\
\hline $\begin{array}{l}\text { Central Plateau Soil } \\
\text { Site Operable Units }\end{array}$ & RL-ER10 & $\cdots$ & -- & - & $\cdots$ & $\cdots$ & -- & $\begin{array}{l}\text { RL-ER02 } \\
\text { RL-ER05 }\end{array}$ & $\begin{array}{l}\text { RL-ER02 } \\
\text { RL-ER07 }\end{array}$ \\
\hline $\begin{array}{l}\text { Environmental } \\
\text { Restoration Disposal } \\
\text { Facility }\end{array}$ & RL-ER10 & -- & $\cdots$ & $\cdots$ & - & -- & RL-ER04 & RL-ER04 & $\begin{array}{l}\text { RL-ER04 } \\
\text { RL-ER07 }\end{array}$ \\
\hline $\begin{array}{l}\text { Central Core Soil } \\
\text { Site Operabie Units }\end{array}$ & RL-ER10 & -- & - & - & $\cdots$ & - & - & RL_ER02 & $\begin{array}{l}\text { RL-ER02 } \\
\text { RL-ER07 }\end{array}$ \\
\hline
\end{tabular}


DOE/RL-97-55

Revision 0

\begin{tabular}{|c|c|c|c|c|c|c|c|c|c|}
\hline \multirow{3}{*}{ Major facility } & \multicolumn{9}{|c|}{ Life cycle } \\
\hline & \multirow{2}{*}{$\begin{array}{l}\text { Program } \\
\text { planning }\end{array}$} & \multirow[b]{2}{*}{ Preconceptual } & \multirow[b]{2}{*}{ Conceptual } & \multicolumn{3}{|c|}{ Execute } & \multirow{2}{*}{$\begin{array}{l}\text { Ops and } \\
\text { maint }\end{array}$} & \multicolumn{2}{|c|}{ Close out } \\
\hline & & & & Design & Construct & Turnover & & $\begin{array}{c}\text { Post- } \\
\text { operation }\end{array}$ & D\&D \\
\hline $\begin{array}{l}\text { South } 600 \text { Area } \\
\text { Groundwater } \\
\text { Operable Units }\end{array}$ & RL-ER10 & $\cdots$ & $\ldots$ & -- & -- & -- & -- & RL-ER0 8 & $\begin{array}{l}\text { RI_ER08 } \\
\text { RI_ER07 }\end{array}$ \\
\hline $\begin{array}{l}\text { South } 600 \text { Area Soil } \\
\text { Site Operable Units }\end{array}$ & RL-ER10 & -- & $\cdots$ & $\cdots$ & $\cdots$ & & -- & RL-ER03 & $\begin{array}{l}\text { RL-ER03 } \\
\text { RL-ER07 }\end{array}$ \\
\hline 326 Building & RL-ER10 & - & $\cdots$ & $\cdots$ & $\cdots$ & & RL-ST01 & $\begin{array}{l}\text { RL-TP14 } \\
\text { RL-ER05 }\end{array}$ & $\begin{array}{l}\text { RL-ER06 } \\
\text { RL-ER07 }\end{array}$ \\
\hline Misc. Rad Labs & RL-ER10 & $\cdots$ & $\cdots$ & -- & -- & & $\ldots$ & $\begin{array}{l}\text { RL-TP14 } \\
\text { RL-ER05 }\end{array}$ & $\begin{array}{l}\text { RL-ER06 } \\
\text { RL-ER07 }\end{array}$ \\
\hline 331 Complex & RL-ER10 & $\cdots$ & - - & - & -- & $\cdots$ & $\begin{array}{c}\text { RL-ST01 } \\
\text { RL-ST02- } \\
09\end{array}$ & $\begin{array}{l}\text { RL-TP14 } \\
\text { RL-ER05 }\end{array}$ & $\begin{array}{l}\text { RL-ER06 } \\
\text { RI-ER07 }\end{array}$ \\
\hline
\end{tabular}

$\mathrm{D} \& \mathrm{D}=$ decontamination and decommissioning

4.3.10.5 Project Safety Authorization Basis/NEPA and Permits. Not applicable.

4.3.10.6 Other Requirements and Planning Assumptions. Not applicable.

4.3.10.7 Interfaces. Not applicable.

4.3.10.8 Logic Diagram. Not applicable.

4.3.10.9 Requirements References. Not applicable.

4.3.10.10 Planning Assumptions. Not applicable. 
DOE/RL-97-55

Revision 0

\section{Pacific Northwest National Laboratory Waste Management Project}

Concurrence: Original signed by J. E. Trevino

R. F. Christensen,

Director,

Science and Technology

Operations Division, U.S. Department of Energy, Richland Operations Office
Approved by: Original signed by R. M. Rosselli

R. M. Rosselli Assistant Manager, Office of Assistant Manager for Science and Technology, U.S. Department of Energy, Richland Operations Office 
DOE/RL-97-55

Revision 0

\subsection{PACIFIC NORTHWEST NATTONAL LABORATORY WASTE MANAGEMENT PROJECT}

\subsubsection{Pacific Northwest National Laboratory Waste Management}

4.4.1.1 Project Description Summary. The Pacific Northwest National Laboratory (Pacific Northwest) provides science and technology development for the Hanford Site cleanup activity and supports other DOE and federal agency programs in contracted research and technology development. The Pacific Northwest Waste Management and Operational Compliance Program receives EM funding to support the National Laboratory's involvement in the cleanup of the Hanford Site. RL provides direct EM funding for Pacific Northwest's Waste Management and Operational Compliance in accordance with EM's assigned responsibilities to provide compliant waste and effluent management services across the DOE Complex. Funds are also provided to ensure the Laboratory operates in compliance with environmental regulations required for Site operations. This funding ensures the National Laboratory's resources are available, on a priority and cost-effective basis, to RL contractors performing cleanup of the Hanford Site.

Specifically, $R L$ has approved the following units of work to be performed:

- Facility S\&M--The DOE facilities assigned to Pacific Northwest are required to be maintained in a minimum safe condition, and the required monitoring of these facilities must be performed to ensure that no inadvertent release of radioactive or other materials of concern occurs. Specifically, Pacific Northwest is expected to maintain these facilities in a manner which maximizes their availability to support science and technology development projects without interruption.

- Newly Generated Waste Management--Pacific Northwest shall develop and maintain an infrastructure capability which manages the consolidation, packaging, and transportation of currently generated wastes for treatment and/or disposal. This task is supported by the compliant management of air and liquid effluents and all types of solid waste generated as a result of conducting project work at DOE's Pacific Northwest facilities. No new project is accepted without ensuring adequate funds are available to manage the waste. Therefore, no new legacy waste inventories are generated.

- Legacy Waste Management--Pacific Northwest shall establish a comprehensive task for managing legacy waste and contamination resulting from past projects conducted within DOE facilities. Funding for this work will be provided in accordance with Site priorities. As a matter of general priority, RL first funds the management of newly generated wastes, and then tries to close out legacy issues as funds are available. 
DOE/RL-97-55

Revision 0

- Environmental Compliance Services--Pacific Northwest ensures that facilities and projects are operated in a way to meet all regulatory requirements. The focus of this task is on developing, maintaining, and ensuring that activities meet the requirements of the various regulations and facility-specific permits (such as RCRA, Clean Air Act of 1955, Clean Water Act of 1977, and TSCA). Other activities include pollution prevention and waste minimization, and compliance with NEPA requirements.

Projects are reviewed individually to ensure compliance. Also, this task must provide for the M\&I of Pacific Northwest's Waste Management and Operational Compliance program in accordance with EM planning requirements for the Hanford Site.

4.4.1.2 Geographic Requirements/Assumptions. Pacific Northwest will meet the following requirements.

- Low-level waste and MLLW from onsite and offsite sources (including special wastes) shall continue to be disposed of in the 200 Area.

- Non-essential, surplus DOE buildings and facilities assigned to Pacific Northwest that do not have identified post-cleanup uses shall be removed.

- Surveillance, maintenance, and safe operations shall be provided for the 325 Building: maintain inventory systems (including radioactive tank wastes); maintain heating, ventilating, and air conditioning, radiation monitoring, and building safeguard systems.

- Effluent monitoring of airborne and liquid releases from DOE facilities assigned to Pacific Northwest shall be conducted.

- Demonstrate excellence in Laboratory management: Be the model for management of National Laboratories.

- Protect the environment and the health and safety of staff and the public through effective conduct of operations.

- Conduct safe, compliant, and environmentally benign operations.

- Become the most productive and cost-effective science and technology provider.

Planning Assumptions: The diverse science and technology development capabilities of Pacific Northwest will extend beyond the environmental restoration of the Hanford Site.

Therefore, RL provides the following planning assumptions for use by Pacific Northwest in developing annual operating plans.

- EM is assigned the Department's responsibility for waste management across the DOE Complex, and will provide sufficient funding to ensure safe and compliant operations. The waste management program for currently generated wastes will be transferred to generators before FY 2006. 
DOE/RL-97-55

Revision 0

- EM will continue to be the assigned landlord with responsibility for the 325 Category II nuclear facility in the Hanford Site 300 Area and therefore will provide direct funding to ensure the safety envelope of the facility is maintained.

- As DOE facilities currently assigned to Pacific Northwest come to the end of their useful life, interface with Transition Projects will be required for stabilization and eventual D\&D. To facilitate this process, the U.S. Department of Energy, Office of Energy Research and EM will establish mutually agreed to objectives and funding mechanisms. RL will provide local field office guidance on the implementation of those agreements in accordance with Site priorities.

\subsubsection{Material and Waste Flow Requirements/Assumptions. Pacific Northwest shall} develop and maintain annual baseline projections that accurately estimate the volume of waste that will be generated. This will allow Pacific Northwest to accurately predict the volume and flow of waste it manages. Annual waste projections shall be provided for current waste generation and legacy waste inventories and shall, at a minimum, contain the following data.

- Projections shall be made for the current fiscal year and each of the prescribed out years requested in RL's annual baseline planning guidance and shall contain estimates for each waste type by waste generator at Pacific Northwest.

- In the current fiscal year, monthly projections shall include estimates for what the Laboratory expects to manage and disposition through onsite and offsite sources. Pacific Northwest shall also report actual volumes managed and explain any significant variances.

- Future year planning shall reflect quarterly estimates and annual totals for each waste type.

- Waste volume projections must clearly support Pacific Northwest's annual timephased budgetary request for infrastructure estimates and shall be documented as the basis of estimate for all authorized work.

- Once the baseline projections are mutually agreed to by RL and Pacific Northwest, the baseline volumes will be subject to a change control process for documenting and tracking formal approvals for additions or reductions to the baseline.

Pacific Northwest will maintain the capability to manage the following types and amounts of newly generated wastes annually. All waste generated shall be disposed of within the year of generation and in accordance with applicable state and federal regulations. 
DOE/RL-97-55

Revision 0

\begin{tabular}{|l|c|}
\hline \multicolumn{1}{|c|}{ Waste type } & Amount \\
\hline Transuranic & $6 \mathrm{~m}^{3}$ \\
\hline Mixed low-level waste & $22 \mathrm{~m}^{3}$ \\
\hline Low-level waste & $400 \mathrm{~m}^{3}$ \\
\hline Hazardous & $42 \mathrm{MT}$ \\
\hline Special waste & $4 \mathrm{~m}^{3}$ \\
\hline
\end{tabular}

Pacific Northwest will provide the capacity to manage the following nuclear materials inventory shown by facility. All units are in cubic meters except depleted $U$, which is in metric tons.

\begin{tabular}{|c|c|c|c|c|c|c|c|c|c|}
\hline Fracility & $\begin{array}{l}\text { Depleted } \\
\text { uranium }\end{array}$ & $\begin{array}{l}\text { Highly } \\
\text { enriched } \\
\text { uranium }\end{array}$ & $\begin{array}{l}\text { Low } \\
\text { enriched } \\
\text { uranium }\end{array}$ & $\begin{array}{c}\text { Misc. } \\
\text { Special } \\
\text { nuclear } \\
\text { material }\end{array}$ & $\begin{array}{l}\text { Misc. } \\
\text { nuclear } \\
\text { material }\end{array}$ & $\begin{array}{c}\text { Misc. } \\
\text { nuclear } \\
\text { fuel }\end{array}$ & $\begin{array}{l}\text { Natural } \\
\text { uranium }\end{array}$ & Plutonium & Strontium \\
\hline $306 W$ & 7 & - & 0.3 & - & 0.05 & - & 0.05 & $\cdots$ & - \\
\hline 318 & 0.01 & 0.01 & $=$ & $=$ & 0.5 & $\cdots$ & 0.01 & -- & $\because$ \\
\hline 325 & 0.8 & 0.3 & 0.5 & 0.05 & 1 & 1 & 0.1 & 1.5 & 0.2 \\
\hline $\begin{array}{l}320,3720 \text {, } \\
\text { and } 3745\end{array}$ & 0.01 & 0.01 & 0.01 & 0.01 & 2 & $\cdots$ & 0.05 & 0.2 & $\cdots$ \\
\hline 329 & $\cdots$ & 0.05 & 0.05 & $\ldots$ & 0.1 & - & $\cdots$ & 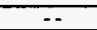 & $\cdots$ \\
\hline $2718 \mathrm{E}$ & - & $=$ & 0.2 & $\cdots$ & $\cdots$ & 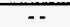 & $=$ & $\cdots$ & $\cdots$ \\
\hline
\end{tabular}

\section{Other Waste/Material Issue Resolution}

Pacific Northwest must characterize as necessary and develop and implement remediation plans for the Waste Identification Database System sites assigned as Science and Technology Operations Division Waste Management Units. Pacific Northwest must also characterize, analyze, and define the path forward for the 300 Area special wastes under Pacific Northwest's responsibility in accordance with Tri-Party Agreement Milestone M-92-00. In addition, a number of legacy contamination sites not captured on the following facility listing are suspected to exist and will need to be added to the cleanup baseline in accordance with the established change control process once the type of contamination is known. These sites include the following:

- DOE radiological legacies deposited in private Pacific Northwest facilities, especially in ventilation systems

- Legacies from the old "Camp Hanford" operations, including oil-contaminated vehicle maintenance areas

- Contamination legacies that are known to exist within DOE-owned facilities and also soil sites within the 300 Area that are suspected to be contaminated, but for which additional characterization and assessment are necessary.

4.4.1.4 Facility Life-Cycle Requirements/Assumptions. The following table identifies lifecycle responsibility for the major Pacific Northwest facilities by PBS number. Pacific Northwest shall develop a plan to dispose of these facilities and ensure orderly transfer to EM-40/60/70 as necessary. No new facilities are currently planned to be constructed. 


\begin{tabular}{|c|c|c|c|c|c|c|c|c|c|c|c|}
\hline \multirow{3}{*}{ Major facility } & \multirow{3}{*}{ Bldg. no. } & \multirow{3}{*}{ Area } & \multicolumn{9}{|c|}{ Life cycle } \\
\hline & & & \multirow{2}{*}{$\begin{array}{l}\text { Program } \\
\text { planning }\end{array}$} & \multirow[b]{2}{*}{ Preconceptual } & \multirow[b]{2}{*}{ Conceptual } & \multicolumn{3}{|c|}{ Execute } & \multirow[b]{2}{*}{ Ops \& maint } & \multicolumn{2}{|c|}{ Close out } \\
\hline & & & & & & Design & Construction & Tumover & & Post-operation & $\mathrm{D} \& \mathrm{D}$ \\
\hline Critical Mass Fissile Storage & $2718 \mathrm{E}$ & $200 \mathrm{E}$ & RLST01 & - & - & - & - & - & RL-ST01 & RLTP10 & RLER05 \\
\hline Material Evaluation Laboratory & $303 \mathrm{C}$ & 300 & Ener Res & $=$ & - & - & - & $=$ & RLST01 & RL-TP14 & RLER05 \\
\hline Material Storage Building & $303 \mathrm{~J}$ & 300 & Ener Res & - & - & - & - & - & RL-STO1 & RLTP13 & RL-TP13 \\
\hline Hazardous Waste Storage Facility & $305 \mathrm{~B}$ & 300 & Ener Res & - & - & - & - & - & Ener Res & RL-TP14 & RL-ER05 \\
\hline Materials Development Laboratory & $306 \mathrm{~W}$ & 300 & Enet Res & - & - & - & $=$ & - & Ener Res & RL-TP14 & RL-ER05 \\
\hline Engineering Development Laboratory & 314 & 300 & Ener Res & - & - & - & - & - & RLST01 & RL-TP14 & RL-EROS \\
\hline Radiological Calibrations Laboratory & 318 & 300 & Ener Res & - & - & - & - & - & RL-TP14 & RL-TP14 & RI-TP14 \\
\hline Analytical \& Nuclear Research Lab & 320 & 300 & Ener Res & - & - & - & - & - & Ener Res & RL-TP14 & RL-EROS \\
\hline Mechanical Properties Laboratory & 323 & 300 & Ener Res & 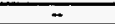 & - & $m$ & 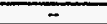 & - & Ener Res & RL-TP14 & RL-ER0S \\
\hline Applied Chemistry Lab & 325 & 300 & RL-ST01 & - & - & - & - & - & RL-ST01 & RL.TP14 & RLEROS \\
\hline Material Science Laboratory & 326 & 300 & Ener Res & $=$ & $=$ & - & - & - & Ener Res & RL-TP14 & RL-ER0S \\
\hline Chemical Sciences Laboratory & 329 & 300 & Ener Res & - & - & - & - & - & Ener Res & RLTP14 & RL-ER05 \\
\hline Life Sciences Laboratory & 331 & 400 & Ener Res & - & - & - & - & - & Ener Res & RL-TP14 & RLERO5 \\
\hline Virology Laboratory & $331 \mathrm{~A}$ & 300 & Enet Res & 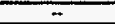 & $=$ & - & $=$ & 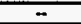 & Ener Res & RL-TP14 & RL-ER0S \\
\hline Dog Kennel & $331 \mathrm{~B}$ & 300 & Ener Res & - & - & - & - & - & RI-STOI & RL-TP13 & RL-TP13 \\
\hline Animal Care Facility Storage Building & $331 \mathrm{C}$ & 300 & Ener Res & $=$ & $=$ & - & $=$ & $=$ & Ener Res & RL-TPI4 & RLTP14 \\
\hline Biomagnetic Effects Laboratory & $331 \mathrm{D}$ & 300 & Ener Res & - & - & - & - & - & Ener Res & RLTP14 & RL-TPI4 \\
\hline Dog Run & 331 Dog Run & 300 & Ener Res & -- & - & - & - & - & Ener Res & RL-TP13 & RL-TP13 \\
\hline Interim Tissue Repository & $331 \mathrm{G}$ & 300 & Ener Res & - & -- & - & -- & $=$ & Ener Res & RL-TPI4 & RLTP14 \\
\hline Aerosol Wind Tunnel Research Facility & $331 \mathrm{H}$ & 300 & Ener Res & - & - & $=$ & $=$ & - & Ener Res & RL-TPI4 & RL-TP14 \\
\hline Packaging Test Facility & 332 & 300 & Ener Res & $=$ & - & - & - & - & Ener Res & RL-TP14 & RLTP14 \\
\hline High Bay Testing Facility & 336 & 300 & Ener Res & 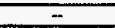 & $=$ & $=$ & $=$ & - & Ener Res & RD-TP14 & RI-TP14 \\
\hline Technical Management Center & 337 & 300 & Ener Res & 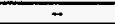 & - & - & $=$ & $=$ & Ener Res & RLTP14 & RLTP14 \\
\hline Maintenance Building & 338 & 300 & Ener Res & - & - & - & - & - & RL-TP14 & RL-TPI4 & RLTTP14 \\
\hline Plant Operations And Maintenance Facility & 350 & 300 & Ener Res & $=$ & $=$ & - & - & - & Ener Res & RI-TP14 & RLTP14 \\
\hline Paint Shop & $350 \bar{A}$ & 300 & Ener Res & - & 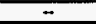 & $=$ & 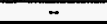 & 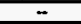 & Ener Res & R्TPL4 & R-TP14 \\
\hline Warehouse & $350 \mathrm{~B}$ & 300 & Ener Res & - & - & - & - & - & Ener Res & RI-TPI4 & RL-TP14 \\
\hline Storage Building (Temporary) & $350 \mathrm{C}$ & 300 & Ener Res & - & - & - & - & - & Ener Res & RL-TP14 & RL-TP14 \\
\hline Oil Storage Facility & $350 \mathrm{D}$ & 300 & Ener Res & - & - & - & - & - & Ener Res & RI-TP14 & RL-TP14 \\
\hline River Monitoring Station & $3614 \mathrm{~A}$ & 300 & Ener Res & - & - & - & - & - & Ener Res & RI-TPI4 & RL-TP14 \\
\hline Radioanalytical Laboratory & 3708 & 300 & Ener Res & - & $=$ & - & $=$ & 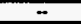 & Ener Res & Rl.TP14 & RL-ER05 \\
\hline Laboratory Equipment Central Pool & $3718 \mathrm{~A}$ & 300 & Ener Res & - & - & - & - & - & Ener Res & RL-TP14 & RLTP14 \\
\hline Laboratory Equipment Central Pool & $3718 \mathrm{~B}$ & 300 & Ener Res & $=$ & - & - & 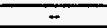 & 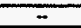 & Ener Res & RLTP14 & RL-ER0S \\
\hline General Storage & $3718 \mathrm{P}$ & 300 & Ener Res & - & - & - & - & - & Ener Res & RL-TP14 & RL-TP14 \\
\hline Environmental science Lab & 3720 & 300 & Ener Res & $\Rightarrow$ & - & $=$ & - & $=$ & Ener Res & RL-TP14 & RE-ER05 \\
\hline Gamma Irradiation Facility & 3730 & 300 & Ener Res & - & - & - & - & - & Ener Res & Rl-TP14 & RL-TP14 \\
\hline Laboratory Equipment Central Pool & 3731 & 300 & Ener Res & $\because$ & - & - & 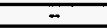 & - & RL-ST01 & RLTP13 & RL-TP13 \\
\hline Graphite Machine Shop & $3731 \mathrm{~A}$ & 300 & Ener Res & - & - & - & - & - & RLSTO1 & RLTP13 & RLTP13 \\
\hline Radtological Calibrations and Stds Lab & 3745 & 300 & Ener Res & 一 & $=$ & - & - & - & RL-STO1 & RL-TP13 & RLTP13 \\
\hline Electron Accelerator Facility & $3745 \mathrm{~A}$ & 300 & Ener Res & - & - & - & - & - & RLSTOI & RLTP13 & RL-TP13 \\
\hline Positive Ion Accelerator Facility & $3745 \mathrm{~B}$ & 300 & Ener Res & $\ldots$ & - & - & - & - & RLSTOI & RL-TP14 & RLER05 \\
\hline Irradiation Physics Building & 3746 & 300 & Ener Res & - & - & - & - & - & RLFT01 & RLTPI3 & RL-TPI3 \\
\hline Radiological Phystcs Building & $3746 \mathrm{~A}$ & 300 & Ener Res & - & - & - & - & - & RL-ST01 & RL-TPIA & RL-ER05 \\
\hline Techrical Líbrary & 3760 & 300 & Ener Res & $=$ & - & - & - & $\overline{--}$ & R-TP14 & RL-TPI4 & RL-TP14 \\
\hline Technical Secunity & 3762 & 300 & Ener Res & - & - & - & 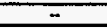 & - & RL-STOI & RL-TP13 & RL-TP13 \\
\hline Offices & 3764 & 300 & Ener Res & - & 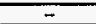 & - & - & -- & RLSTO1 & RI-TP13 & RLTP13 \\
\hline Offices & 3767 & 300 & Ener Res & - & $=$ & $=$ & - & - & RL-STO1 & RLTPI3 & RL-TP13 \\
\hline Elevator Control Building & $622 \mathrm{~A}$ & 600 & Ener Res & - & $=$ & - & $=$ & 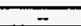 & Ener Res & RL-TP13 & RLTP13 \\
\hline
\end{tabular}




\begin{tabular}{|c|c|c|c|c|c|c|c|c|c|c|c|}
\hline \multirow{3}{*}{ Major facility } & \multirow{3}{*}{ Bldg. no. } & \multirow{3}{*}{ Area } & \multicolumn{9}{|c|}{ Life cycle } \\
\hline & & & \multirow{2}{*}{$\begin{array}{l}\text { Program } \\
\text { planning }\end{array}$} & \multirow[b]{2}{*}{ Preconceptual } & \multirow[b]{2}{*}{ Conceptual } & \multicolumn{3}{|c|}{ Execute } & \multirow[b]{2}{*}{ Ops \& maint } & \multicolumn{2}{|c|}{ Clese out } \\
\hline & & & & & & Design & Construction & Tumover & & Post-operation & D\&D \\
\hline Pilot Balloon Release Building & $622 \mathrm{~B}$ & 600 & Ener Res & - & 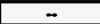 & - & - & - & Ener Res & RL-TP13 & RL-TP13 \\
\hline Storage Buflding & $622 \mathrm{C}$ & 600 & Ener Res & - & - & $=$ & - & - & Ener Res & RL-TP13 & RLTP13 \\
\hline Storage Building & $622 \mathrm{D}$ & 600 & Ener Res & - & 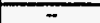 & - & - & - & RL-ST01 & R[-TP13 & RLTP13 \\
\hline Field office Building & $622 \mathrm{~F}$ & 600 & Ener Res & - & - & - & - & - & Ener Res & RL-TP13 & RLTP13 \\
\hline Meteorology Laboratory & $622 \mathrm{R}$ & 600 & Ener Res & - & - & - & - & - & Ener Res & R/.TP13 & RL-TP13 \\
\hline Radioecology Field Lab & 646 & 600 & Ener Res & - & - & - & - & - & RL-ST01 & RL-TP13 & RL-TP13 \\
\hline Space Science Laboratory & $6652 \mathrm{C}$ & 600 & Ener Res & - & $=$ & - & - & - & RL-STOI & RLFTP13 & RLTP13 \\
\hline Storage Building & 6652CSHED & 600 & Ener Res & - & - & - & 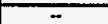 & - & RLSTO1 & RL-TP13 & RLTP13 \\
\hline Atmospheric Facilify - Observatory & 6652 Dome 1 & 600 & Ener Res & - & - & - & - & - & Ener Res & RL-TP13 & RLTP13 \\
\hline Atmospheric Facility & 6652 Dome 2 & 600 & Ener Res & -. & $=$ & - & - & - & RI-ST01 & RL-TP13 & RLTP13 \\
\hline Lysimeter Prep Bldg & $6652 \mathrm{E}$ & 600 & Ener Res & - & - & - & - & - & Ener Res & RL-TP13 & $\mathrm{RLTPI3}$ \\
\hline Ale Field Storage Building & $6652 \mathrm{G}$ & 600 & Ener Res & - & $=$ & - & $=$ & $=$ & RL-STO1 & RL-TP13 & RLTP13 \\
\hline Ale Laboratory 1 & $6652 \mathrm{H}$ & 600 & Ener Res & - & - & $=$ & - & - & RLSTO1 & RL-TP13 & RL-ER02 \\
\hline Ale Headquarters & 66521 & 600 & Ener Res & - & - & - & - & - & RL-ST01 & RL-TP13 & RL-TP13 \\
\hline Ale Laboratory 11 & 66525 & 600 & Ener Res & - & $=$ & - & - & $=$ & RI-STO1 & RL-TP13 & RLTP13 \\
\hline Lower Pump House & $6652 \mathrm{LP}$ & 600 & Ener Res & - & - & - & - & - & RL_STOI & RL-TP13 & RL-TP13 \\
\hline Fallout Laboratory & $6652 \mathrm{M}$ & 600 & Ener Res & - & -- & - & $=$ & - & RL_STOI & RL-TP13 & RL-TP13 \\
\hline Storage Building & 66520 & 600 & Ener Res & - & - & - & - & - & RI-STO1 & RLTP13 & $\overline{R !-T P 13}$ \\
\hline Fire Protection Pump House & $6652 \mathrm{PH}$ & 600 & Ener Res & - & - & - & 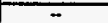 & 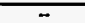 & RL-ST01 & RL-TP13 & RL-TP13 \\
\hline Upper Pump House & 6652UP & 600 & Ener Res & - & - & - & - & $=$ & RL-STO1 & RL-TP13 & RL-TP13 \\
\hline Whole Body Counter Laboratory & $747 \mathrm{~A}$ & 700 & Ener Res & - & - & - & $=$ & $=$ & Ener Res & RL.TP13 & RLTP13 \\
\hline Boat Storage & WBF-1 & 100 & Ener Res & - & - & - & - & - & RLSTOI & RLTP13 & RLTP13 \\
\hline Storage Building & WBE-2 & 100 & Ener Res & - & - & $=$ & - & $=$ & RL-STO1 & RLTP13 & RL-TP13 \\
\hline EMSL & 3020 & 3000 & Ener Res & $=$ & $=$ & - & - & - & Ener Res & RITP13 & RI-ER0S \\
\hline
\end{tabular}


DOE/RL-97-55

Revision 0

Disposition of remaining legacy waste materials from in and around DOE's facilities assigned to Pacific Northwest in the 300 Area is required. Pacific Northwest will develop and execute a disposition plan for the buildings and associated ground contamination sites listed below. Most of the sites are not characterized and Pacific Northwest must plan an initial phase for assessment including an assessment of risk associated with each legacy contamination site to provide the necessary information for proceeding on a priority-based path for site remediation.

\subsubsection{Project Safety Authorization Basis/NEPA and Permits. Operations in Pacific} Northwest facilities are to be conducted safely and in accordance with the safety authorization bases established for each individual facility. Applicable to this project is the new safety Authorization Basis for the 325 Building, PNL-SAR-325, Safety Analysis Report for 325 Building (PNL 1996a). Also included in the Authorization Basis for this facility are the Operational Safety Requirements contained in PNL-LIM-325, 325 Building Operating Limits (PNL 1996b).

Although no programmatic NEPA documentation addresses the overall Pacific Northwest research and technology development mission or EM facilities operated by the Laboratory, Pacific Northwest shall continue to review all proposed activities on a project-by-project basis to ensure compliance with NEPA.

Other facilities that are to be transferred to EM but which are currently operated by other programs are not addressed here.

4.4.1.6 Interfaces. Pacific Northwest shall establish and maintain the following interfaces for the Pacific Northwest Waste Management and Operational Compliance activities.

Solid Waste Storage and Disposal--Pacific Northwest solid wastes shall be transferred to the CWC for storage before treatment and/or disposal and therefore interface directly with the Hanford Site's Waste Management Project.

Liquid Waste Program--Pacific Northwest nonradioactive liquid effluents shall be piped to the 300 Area TEDF for disposition. Through 1998, the radioactive and mixed waste liquid effluents shall be discharged via the 300 Area Radioactive Liquid Waste System (RLWS) to the 340 Waste Handling Facility for transport to the 200 Area DSTs. Subsequent to 1998 , Pacific Northwest shall provide a capability for the accumulation of all 300 Area Pacific Northwest facility liquid radioactive and mixed waste in the 325 Facility for land transport to the 200 Area double-shell storage tanks.

Facility Stabilization--As DOE facilities assigned to Pacific Northwest reach the end of their useful life and become surplus to site missions, they shall be transferred to either the FSP or the ER Project for final disposition.

\subsubsection{Logic Diagram. Refer to Figure 4-10.}


DOE/RL-97-55

Revision 0

Figure 4-10. Logic Diagram for the Pacific Northwest National Laboratory Environmental Restoration Work.

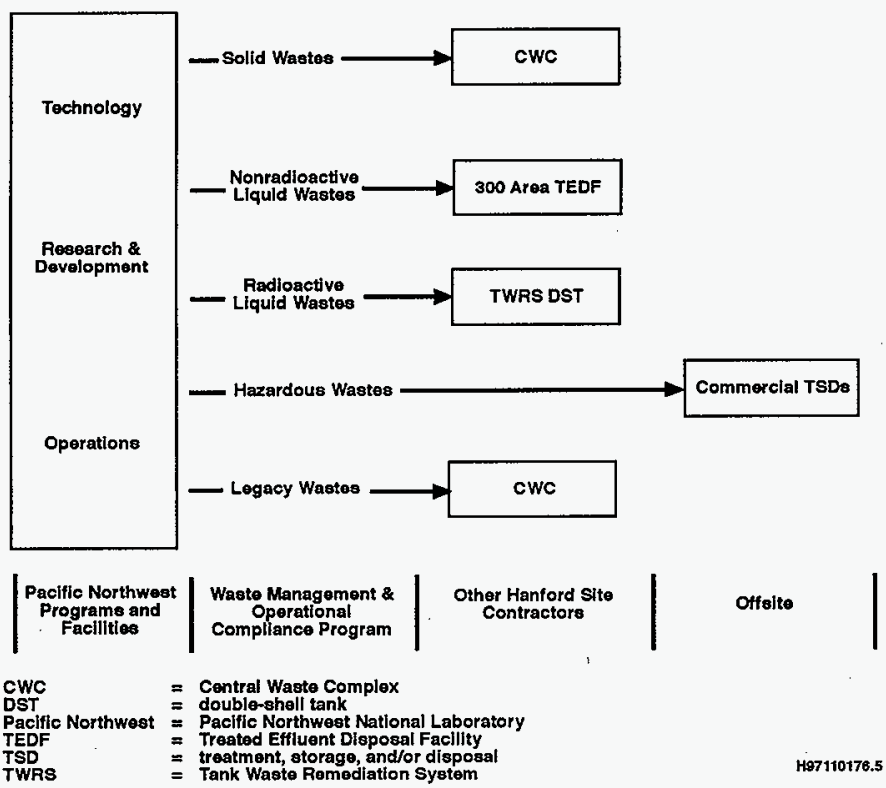

4.4.1.8 Requirements References. Pacific Northwest shall comply with the following DOE Orders, federal, state, and local regulations:

- Clean Air Act of 1955

- Clean Water Act of 1977

- WAC 173-303, "Dangerous Waste Regulations"

- 49 CFR, "Transportation"

- Federal Environmental Pesticide Control Act of 1972

- Tri-Party Agreement Milestone M-92-00 
DOE/RL-97-55

Revision 0

- Hanford Facility RCRA Permit WA7890008967 (Ecology 1994)

- 29 CFR 1910, "Occupational Safety and Health Standards"

- WAC 173-307, "Plans"

- 40 CFR 61, "National Emissions Standards for Hazardous Air Pollutants"

- NEPA

- Pollution Prevention Act of 1990

- WAC 173-400-141, "Prevention of Significant Deterioration"

- 10 CFR 835, "Radiation Protection for Occupational Workers"

- 10 CFR 834 (when promulgated), "Radiation Protection for Public and Environment"

- 40 CFR 61, Subpart H, "Radionuclide Air Emissions"

- Regulation 80-7 of the Benton-Franklin-Walla Walla Counties Air Pollution Control Authority

- RCRA

- TSCA

- WAC 246-247, "Radiation Protection--Air Emissions"

- All other applicable environmental laws, regulations, and other requirements.

4.4.1.9 Planning Assumptions. Pacific Northwest shall use the following general planning assumptions in the development of short- and long-term planning documents for Pacific Northwest.

- The $S \& M$, waste management, and compliance activities are basic infrastructure support to the DOE-EM facilities assigned to the Pacific Northwest research and technology development mission which will continue beyond FY 2046.

- Facilities associated with the continuous function of the Multi-Program Laboratory will continue to be used beyond the Hanford Site cleanup mission.

- The 325 Building will continue to support the Hanford Site cleanup mission at least through FY 2046 and when the Hanford Site cleanup is complete. It may support other DOE missions beyond that time. 
- The 340 Waste Handling Facility operations will continue to accept liquid waste from Pacific Northwest 300 Area facilities through FY 1998. After 1998, the 325 Radioactive Liquid Waste System modifications will be completed and in use.

- Selected 300 Area facilities surplus to the.Hanford Site mission shall be vacated, placed in safe stand-by condition, and transferred to Facility Transition or ER for final disposition.

- Pacific Northwest shall operate and maintain laboratory facility monitoring and sampling systems for the process sewer and retention process sewer and will monitor and sample the 331 Building outfall discharges to meet NPDES permit conditions.

- EM will continue to provide waste management oversight and disposal pathways to other DOE programs, including Energy Research and Nuclear Energy, that perform research and development operations at the Hanford Site.

- Legacy wastes associated with the 300 Area and Richland North operations will be identified and plans for final disposition pathways will be developed. 
DOE/RL-97-55

Revision 0

May 29, 1998

Tank Waste Remediation System Privatization Phase I

Concurrence: Original signed by D. D. Wodrich

D. D. Wodrich,

Senior Technical Advisor, Office of Assistant Manager

for Tank Waste Remediation System,

U.S. Department of Energy,

Richland Operations Office
Approved by: Orig. signed by M. A. Hunemuller

J. E. Kinzer,

Assistant Manager,

Office of Assistant Manager

for Tank Waste

Remediation System,

U.S. Department of Energy,

Richland Operations Office 


\subsection{TWRS PRIVATIZATION PHASE I}

This section is based on the TWRS baseline as of June 1, 1998. Following selection of the privatization contractor, this information will be updated to reflect the contractor's process and interface with the rest of the TWRS process.

\subsubsection{Privatization Phase I Project}

The TWRS scope includes immobilization of tank waste for disposal (Section 4.2.1). This will be accomplished by private contractors. The privatization of Hanford Site tank waste treatment is divided into two phases: a demonstration phase and a full-production phase. Phase I objectives are to demonstrate the technical and business viability of using privatized facilities to treat Hanford Site tank waste; define and maintain required levels of radiological, nuclear, process, and occupational safety; maintain environmental protection and compliance; and substantially reduce life-cycle costs and time required to treat Hanford Site tank waste. Phase II will be a full-scale production phase in which the facilities will be configured so remaining waste can be processed. Phase II is described in Section 4.6.

4.5.1.1 Project Description Summary. The purpose of the Privatization Phase I Project is to demonstrate treatment of Hanford Site tank waste (both LAW and HLW feed). The contractor(s) will receive LAW feed, separate it into low-activity and high-level fractions, and treat and immobilize the low-activity fraction. If the contractor(s) provide LAW and HLW services, they will treat and immobilize $\mathrm{HLW}$ feed and the separated $\mathrm{Cs}$, technetium, Sr, and transuranics in the high-level fraction; otherwise, these will be returned to the DOE.

Phase I consists of Part A and Part B. Part A is a 20-month development period to establish the technical, operational, regulatory, business, and financial elements required by privatized facilities that will provide waste treatment services on a fixed-unit-price basis. Based on Part A performance, none, one, or two of the contractors will be authorized to process waste in Part B at fixed-unit prices. Feed from three LAW envelopes and one HLW envelope (about $13 \%$ of total tank waste) will be processed during a 10-year period (2002 to 2011), followed by deactivation of the contractors' plants.

4.5.1.2 Geographic Requirements/Assumptions. The TWRS Privatization Phase I Project will support the following geographic goal.

\section{Requirements:}

- None. 


\section{Planning Assumptions:}

- The 200 Area and Central Plateau will be used for the management of NM, the collection and disposal of waste materials that remain onsite, and for other related and compatible uses. Cleanup levels and disposal standards will be established that are consistent with the long-term uses.

- This project will support the prior assumption by treating/immobilizing LAW and $\mathrm{HLW}$ in the Central Plateau to the extent needed for storage/disposal.

\subsubsection{Material and Waste Flow Requirements/Assumptions.}

\section{Requirements:}

- The Phase I private contractors will receive from the Retrieval Project the following feed quantities in accordance with the contract:

\begin{tabular}{|l|l|l|}
\hline \multicolumn{1}{|c|}{ Waste envelope } & \multicolumn{1}{|c|}{ Minimum order quantity per contract } & \multicolumn{1}{c|}{ Maximum order quantity per contract } \\
\hline A & $2,600 \mathrm{MT}$ of sodium & $4,900 \mathrm{MT}$ of sodium* \\
\hline B & $100 \mathrm{MT}$ of sodium & $1,000 \mathrm{MT}$ of sodium* \\
\hline C & $100 \mathrm{MT}$ of sodium & $2,400 \mathrm{MT}$ of sodium* \\
\hline $\begin{array}{l}\text { D (if high-level } \\
\text { waste included in } \\
\text { contract) }\end{array}$ & $\begin{array}{l}245 \mathrm{MT} \text { oxides exclusive of sodium and } \\
\text { silicon }\end{array}$ & $340 \mathrm{MT}$ oxides exclusive of sodium and silicon \\
\hline
\end{tabular}

*The maximum combined quantity of Envelopes A, B, and C shall not exceed 5,100 MT of sodium.

- The privatized services and products must meet the standards defined in the privatization contracts.

\section{Planning Assumptions:}

- A contract will be placed for LAW only and a contract will be placed for LAW and HLW. The contracts will be extended to supply the maximum order quantities. A total of 12,520 packages of ILAW will be produced in Phase I based on maximum order quantity. A total of 600 canisters $(4.5 \mathrm{~m})$ of IHLW will be produced in Phase I.

\subsubsection{Facility Life-Cycle Requirements and Assumptions.}

\section{Requirements:}

- The requirements for private contractor facilities and operations are contained in the TWRS privatization contracts with Lockheed Martin Advanced Environmental Services and BNFL, Inc. The private contractors are responsible for conceptual design, construction, turnover, operations and maintenance, and deactivation of the 
DOE/RL-97-55

Revision 0

May 29, 1998

Phase I facilities. The Hanford Site M\&I Contractor will provide D\&D of those facilities after Phase I waste processing is complete. Private contractors are responsible for obtaining all required permits, including the RCRA Part B Permit.

\section{Planning Assumptions:}

- The privatization contracts will be executed essentially as planned, with two contractors operating a LAW processing facility and a combined HLW/LAW plant. It is assumed the capacity of these plants will be as described in the current contract, with a processing capacity of 1,200 MT of LAW and $60 \mathrm{MT}$ of $\mathrm{HLW}$ processed annually.

\begin{tabular}{|c|c|c|c|c|c|c|c|c|c|}
\hline \multirow{3}{*}{$\begin{array}{l}\text { Major } \\
\text { facility }\end{array}$} & \multicolumn{9}{|c|}{ Life cycle } \\
\hline & \multirow{2}{*}{$\begin{array}{l}\text { Program } \\
\text { planning }\end{array}$} & \multirow{2}{*}{$\begin{array}{c}\text { Pre- } \\
\text { conceptual }\end{array}$} & \multirow{2}{*}{ Conceptual } & \multicolumn{3}{|c|}{ Execute } & \multirow{2}{*}{$\begin{array}{l}\text { Operations } \\
\text { and } \\
\text { maintenance }\end{array}$} & \multicolumn{2}{|c|}{ Close out } \\
\hline & & & & Design & Construction & Tumover & & $\begin{array}{c}\text { Post- } \\
\text { operations }\end{array}$ & D\&D \\
\hline $\begin{array}{l}\text { LAW Plant } \\
\text { Phase I }\end{array}$ & $\cdots$ & - & RL-TW06 & RL-TW06 & RL-TW06 & RL-TW06 & RL-TW06 & RL-TW06 & RL-TW06 \\
\hline $\begin{array}{l}\text { LAW/HLW } \\
\text { Plant Phase I }\end{array}$ & $\cdots$ & $\cdots$ & RL-TW06 & RL-TW06 & RL-TW06 & RL-TW06 & RL-TW06 & RLTW06 & RL-TW06 \\
\hline
\end{tabular}

$\mathrm{D} \& \mathrm{D}=$ decontamination and decommissioning

$\mathrm{HLW}=$ high-level waste

LAW $=$ low-activity waste

4.5.1.5 Project Safety Authorization Basis/NEPA and Permits. Each private contractor shall develop and implement an integrated, standards-based, safety management program to ensure that radiological, nuclear, and process safety requirements are defined, implemented, and maintained. Radiological, nuclear, and process safety requirements shall be adapted to the specific hazards that are identified with the contractor's waste treatment services.

The contractors integrated standards-based safety management program shall be developed to comply with the specific nuclear safety regulations defined under the 10 CFR 800 series of nuclear safety requirements and with the regulatory program established in the following:

- DOE/RL-96-03, DOE Regulatory Process for Radiological, Nuclear, and Process Safety for TWRS Privatization Contractors (Vieth 1996a)

- DOE/RL-96-04, Process for Establishing a Set of Radiological, Nuclear, and Process Safety Standards and Requirements for TWRS Privatization (Vieth 1996b)

- DOE/RL-96-05, Concept of the DOE Regulatory Process for Radiological, Nuclear, and Process Safety for TWRS Privatization Contractors (Vieth 1996c)

- DOE/RL-96-06, Top-Level Radiological, Nuclear, and Process Safety Standards and Principles for TWRS Privatization Contractors (Vieth 1996d). 
The DOE Regulatory Unit will provide nuclear, radiological, and process safety oversight of the private contractors. Each contractor shall prepare and submit to the DOE Regulatory Unit for review and approval several radiological, nuclear, and process safety deliverables in accordance with the privatization contracts.

The DOE is responsible for meeting its compliance obligations under NEPA. The contractor(s) shall be required to provide materials to support compliance efforts. The TWRS EIS ROD decided to implement the phased implementation alternative for tank waste. Permits for storage and treatment operations will be regulated and administered by Ecology and the U.S. Environmental Protection Agency under the RCRA and state of Washington Hazardous Waste Management Act. All RCRA/Dangerous Waste permits will be signed by the contractor and will be signed by the DOE when required. Ecology, the U.S. Environmental Protection Agency, and/or the Washington Department of Health will regulate radioactive and nonradioactive air emissions. The contractor(s) shall integrate their operations and requirements into the Hanford Site-wide air compliance frame work.

\subsubsection{Other Requirements and Planning Assumptions.}

\section{Requirements:}

- Tri-Party Agreement Milestone M-60-10, "Select Two (2) COCO Contractors and Issue DOE-Signed Authorizations to Proceed with Part B (as Defined in the Request for Proposal [RFP] or Subsequently Negotiated Contract(s) Works for LAW Pretreatment and Immobilization"

- Tri-Party Agreement Milestone M-60-11, "Start Construction for Two (2) Phase I LAW Pretreatment and Immobilization Facilities"

- Tri-Party Agreement Milestone M-60-12, "Start Hot Operations of Two (2) Contractor-Owned, Contractor-Operated (COCO) Phase I LAW Pretreatment and Immobilization Facilities"

- Tri-party Agreement Milestone M-20-58, "Submit LAW Facility Part B Dangerous Waste Permit Application to Ecology"

- Tri-Party Agreement Milestone M-50-04, "Start Hot Operations of High-Level Waste (HLW) Pretreatment Facility"

- Tri-Party Agreement Milestone M-51-03, "Initiate Hot Operations of the HLW Vitrification Facility." 


\section{Planning Assumptions:}

- The strategy for waste immobilization will be implemented essentially as described in the privatization contract, with a LAW plant and a combined HLW/LAW plant. Vitrification will be the immobilization technology. Private contractors will start construction by the end of 1999 .

- During Phase I, private contractors will be responsible for LAW treatment and immobilization, HLW immobilization, and facility deactivation.

- The option to extend Phase I operations will be exercised through 2011.

- TRU tank waste will not be segregated but will be immobilized with FLW.

4.5.1.7 Interfaces. This project provides, receives, or shares in the following interfaces.

\begin{tabular}{|l|l|l|}
\hline \multicolumn{1}{|c|}{ Project title } & \multicolumn{1}{|c|}{$\begin{array}{c}\text { Project } \\
\text { number }\end{array}$} & \multicolumn{1}{|c|}{ Interface } \\
\hline $\begin{array}{l}\text { Tank Waste } \\
\text { Characterization }\end{array}$ & RL-TW01 & Receives samples \\
\hline Retrieval Project & RL-TW04 & $\begin{array}{l}\text { Receives tank waste feed (low-activity waste and high-level } \\
\text { waste) and provides returns }\end{array}$ \\
\hline $\begin{array}{l}\text { Process Waste Support } \\
\text { Project }\end{array}$ & RL-TW05 & $\begin{array}{l}\text { Receives technical management support and participates in } \\
\text { Integrated Process/Product Teams }\end{array}$ \\
\hline $\begin{array}{l}\text { Privatization Infrastructure } \\
\text { Project }\end{array}$ & RL-TW08 & Receives selected utilities and services \\
\hline $\begin{array}{l}\text { Immobilized Tank Waste } \\
\text { Storage \& Disposal Project }\end{array}$ & RL-TW09 & $\begin{array}{l}\text { Receives transport, storage, and disposition of privatization } \\
\text { products (immobilized waste, separated Cs, and non-routine high- } \\
\text { level solid waste) }\end{array}$ \\
\hline $\begin{array}{l}\text { Tank Waste Remediation } \\
\text { System Management } \\
\text { Support }\end{array}$ & RL-TW10 & $\begin{array}{l}\text { Receives management, budget, and cost reporting support and } \\
\text { cooperates in outyear planning }\end{array}$ \\
\hline $\begin{array}{l}\text { Solid Waste Storage \& } \\
\text { Disposal }\end{array}$ & RL-WM03 & Receives solid waste disposal service support \\
\hline Liquid Waste & RL-WM05 & Receives liquid effluent treatment/disposal support \\
\hline
\end{tabular}

The Waste Management Program will provide solid waste, liquid waste, and analytical laboratory support as defined in the most recent approved revision of the solid waste, liquid waste, and Analytical Laboratory Services forecasts.

4.5.1.8 Logic Diagram. Refer to Figures 4-1 and 4-2. 
DOE/RL-97-55

Revision 0

May 29, 1998

\subsubsection{Requirements References.}

- Contract with Lockheed Martin Advanced Environmental Services, DE-AC06-96RL13309 (RL 1996b)

- Contract with BNFL, Inc., DE-AC06-96RL13308 (RL 1996a). 
DOE/RL-97-55

Revision 0

May 29, 1998

Tank Waste Remediation System Privatization Phase II

Concurrence: Original signed by D. D. Wodrich

D. D. Wodrich, Senior Technical Advisor, Office of Assistant Manager for Tank Waste Remediation System, U.S. Department of Energy, Richland Operations Office
Approved by: Orig, signed by M. A, Hunemuller

J. E. Kinzer, Assistant Manager, Office of Assistant Manager for Tank Waste Remediation System, U.S. Department of Energy, Richland Operations Office 


\subsection{TWRS PRIVATIZATION PHASE II}

This section is based on the TWRS baseline as of June 1, 1998. Following selection of the privatization contractor, this information will be updated to reflect the contractor's process and interface with the rest of the TWRS process.

\subsubsection{Privatization Phase II Project}

The TWRS scope includes immobilization of tank waste for disposal (Section 4.2.1). This will be accomplished by private contractors. The privatization of Hanford Site tank waste treatment is divided into two phases: a demonstration phase and a full-production phase. Phase I objectives are to demonstrate the technical and business viability of using privatized facilities to treat Hanford Site tank waste; define and maintain required levels of radiological, nuclear, process, and occupational safety; maintain environmental protection and compliance; and substantially reduce life-cycle costs and time required to treat Hanford Site tank waste. Phase II will be a full-scale production phase in which the facilities will be configured so remaining waste can be processed. Phase II objectives are to implement the lessons from Phase I, process remaining tank waste and the $\mathrm{Cs} / \mathrm{Sr}$ capsules into suitable forms for final disposal, achieve price competition and cost savings throughout the Phase II effort, and meet or exceed Tri-Party Agreement benchmark performance milestones. Note that concurrent with Phase II, a private contractor will assume responsibility for operation, maintenance, and retrieval of tank waste under the Retrieval Project (see Section 4.2.1.4.1).

4.6.1.1 Project Description Summary. The purpose of the Privatization Phase II Project is to treat and immobilize remaining tank waste and capsules. The project will receive LAW and highlevel feeds, separate the low-activity feed into low-activity and high-level fractions, treat and immobilize the fractions, and return the immobilized low-activity and high-level products. The Privatization Phase II Project scope includes D\&D of its facilities. Private contractors will design, construct, operate, decontaminate, and decommission contractor-owned facilities and produce ILAW and IHLW products. Contractors will be compensated through fixed-unit prices for the service of processing waste. Waste retrieval operations will also be privatized.

The LAW immobilization during Phase II will be performed by two or more contractors. Retrieval operations will be performed by an (assumed) different private contractor. Sludge washing will be conducted by the HLW contractor. Low-activity waste plants will operate through the completion of SST closure in 2024. The HLW plant will operate from 2012 to 2028. Separated products from the LAW plants will be transferred to the HLW contractor for immobilization. (NOTE: An LAW plant could be combined with the HLW plant into a single facility.) The capsules will be treated as HLW, immobilized, and disposed in the national geologic repository.

4.6.1.2 Geographic Requirements/Assumptions. The Privatization Phase II Project will support the following geographic goal. 
DOE/RL-97-55

Revision 0

May 29, 1998

\section{Requirements:}

- None.

\section{Planning Assumptions:}

- The 200 Area and Central Plateau will be used for the management of NM, the collection and disposal of waste materials that remain onsite, and for other related and compatible uses. Cleanup levels and disposal standards will be established that are consistent with the long-term uses.

- This project will support the prior assumption by treating/immobilizing low-activity and high- level tank waste in the Central Plateau to the extent needed for storage/disposal.

\subsubsection{Material and Waste Flow Requirements.}

\section{Requirements:}

- During Phase II, all remaining tank waste will be retrieved and processed.

\section{Planning Assumptions:}

- Phase II will produce approximately 83,200 ILAW packages that are 1.2 by 1.2 by $1.8 \mathrm{~m}$. The LAW plants will be sized to accept waste feed at a sufficient rate to retrieve all waste from SSTs by 2018 , and complete LAW pretreatment and immobilization by end of 2024 and HLW vitrification (immobilization) by end of 2028 .

- The Phase II HLW plant will use vitrification with a minimum $34 \%$ waste loading, exclusive of $\mathrm{Na}$ and $\mathrm{Si}$. The HLW plant will operate from 2012 to approximately 2028. It is assumed that Phase II will produce a maximum of $14,300 \mathrm{~m}^{3}$ of HIL glass (a waste minimization goal of $10,000 \mathrm{~m}^{3}$ has been established).

\subsubsection{Facility Life-Cycle Requirements/Assumptions.}

\section{Requirements:}

- The DOE, assisted by the Waste Disposal Integration Team, is responsible for program planning (including preparation and release of the Phase II RFP in 2005). The private contractors are responsible for preconceptual design, conceptual design, construction, turnover, operations and maintenance, deactivation, and D\&D of the Phase II facilities. 


\section{Planning Assumptions:}

- The Phase II privatization contracts will authorize two contractors operating a LAW processing facility and a combined HLW/LAW plant.

- A Phase II contract will be implemented during 2005 and will extend through 2028 and beyond for D\&D activities.

\begin{tabular}{|c|c|c|c|c|c|c|c|c|c|}
\hline \multirow{3}{*}{$\begin{array}{l}\text { Major } \\
\text { facility }\end{array}$} & \multicolumn{9}{|c|}{ Life cycle } \\
\hline & \multirow{2}{*}{$\begin{array}{l}\text { Program } \\
\text { planning }\end{array}$} & \multirow{2}{*}{$\begin{array}{c}\text { Pre- } \\
\text { conceptual }\end{array}$} & \multirow[b]{2}{*}{ Conceptual } & \multicolumn{3}{|c|}{ Execute } & \multirow{2}{*}{$\begin{array}{l}\text { Operations and } \\
\text { maintenance }\end{array}$} & \multicolumn{2}{|c|}{ Close out } \\
\hline & & & & Design & Construction & Tumover & & $\begin{array}{c}\text { Post- } \\
\text { operations }\end{array}$ & $\mathrm{D} \& \mathrm{D}$ \\
\hline $\begin{array}{l}\text { LAW } \\
\text { Treatment } \\
\text { Facility } \\
\text { Phase II }\end{array}$ & RL-TWOS & RL-Tw0S & RL-TW07 & RL.TW07 & RL-TW07 & RL-TW0T & RLTW07 & RL-TW07 & RL-TW07 \\
\hline $\begin{array}{l}\text { HLW } \\
\text { Treatment } \\
\text { Facility } \\
\text { Phase II }\end{array}$ & RL-Tw05 & RL-TW0S & RL-TW07 & RL-TW07 & RL-TW07 & RL-TW07 & RL-TW07 & RL-TW07 & RL-TW07 \\
\hline
\end{tabular}

$D \& D=$ decontamination and decommissioning

HLW $=$ high-level waste

$\mathrm{LAW}=$ low-activity waste

4.6.1.5 Project Safety Authorization Basis/NEPA and Permits. The requirements for the safety Authorization Basis for Phase II have not been developed. It is assumed that each private contractor will develop and implement an integrated, standards-based, safety management program to ensure that radiological, nuclear, and process safety requirements are defined, implemented, and maintained in accordance with U.S. Nuclear Regulatory Commission policies and procedures.

\subsubsection{Other Requirements and Planning Assumptions.}

Requirements: Selected key Tri-Party Agreement milestones are as follows:

- Tri-Party Agreement Milestone M-50-00, "Complete Pretreatment Processing of Hanford Tank Waste"

- Tri-Party Agreement Milestone M-51-00, "Complete Vitrification of Hanford HighLevel Waste"

- Tri-Party Agreement Milestone M-60-00, "Complete Pretreatment and Immobilization of Hanford Low Activity Tank Waste (LAW)"

- Tri-Party Agreement Milestone M-60-13, "Initiate Negotiations on Phase II LAW Pretreatment and Immobilization Milestone." 
DOE/RL-97-55

Revision 0

May 29, 1998

\section{Planning Assumptions:}

- During Phase II, private contractors will be responsible for waste retrieval and transfer, LAW and HLW treatment and immobilization, and facility D\&D.

Responsibility for DST operations will be transferred to a private contractor in 2011.

- The HLW plant will operate from 2012 to approximately 2028.

- The 242-A Evaporator will support waste processing until 2011. Afterwards, private contractors will provide the required evaporator capability.

- No new waste, e.g., from non-TWRS facilities or SST closure, will be accepted by DSTs after 2018 to facilitate completion of the Privatization Phase II Project.

- $\mathrm{Cs} / \mathrm{Sr}$ capsules will be treated as HLW, immobilized, and disposed in the national geologic repository.

- TRU tank waste will not be segregated but will be immobilized with HLW.

4.6.1.7 Interfaces. This project provides, receives, or shares in the following interfaces:

\begin{tabular}{|l|l|l|}
\hline \multicolumn{1}{|c|}{ Project title } & \multicolumn{1}{|c|}{$\begin{array}{c}\text { Project } \\
\text { number }\end{array}$} & \multicolumn{1}{c|}{ Interface } \\
\hline Retrieval Project & RL-TW04 & $\begin{array}{l}\text { Receives tank waste feed (low-activity waste and high-level } \\
\text { waste) }\end{array}$ \\
\hline $\begin{array}{l}\text { Process Waste Support } \\
\text { Project }\end{array}$ & RL-TW05 & Participates in Integrated Process/Product Teams \\
\hline $\begin{array}{l}\text { Privatization Infrastructure } \\
\text { Project }\end{array}$ & RL-TW08 & Receives selected utilities and services \\
\hline $\begin{array}{l}\text { Immobilized Tank Waste } \\
\text { Storage \& Disposal Project }\end{array}$ & RL-TW09 & $\begin{array}{l}\text { Receives transport, storage, and disposition of privatization } \\
\text { products }\end{array}$ \\
\hline $\begin{array}{l}\text { Tank Waste Remediation } \\
\text { System Management } \\
\text { Support }\end{array}$ & RL-TW10 & $\begin{array}{l}\text { Receives management, budget, and cost reporting support and } \\
\text { cooperates in outyear planning }\end{array}$ \\
\hline $\begin{array}{l}\text { Solid Waste Storage \& } \\
\text { Disposal }\end{array}$ & RL-WM03 & Receives solid waste disposal service support \\
\hline Liquid Waste & RL-WM05 & Receives liquid effluent treatment/disposal support \\
\hline
\end{tabular}

The Waste Management Program will provide solid waste, liquid waste, and analytical laboratory support as defined in the most recent approved revision of the solid waste, liquid waste, and Analytical Laboratory Services forecasts. 
DOE/RL-97-55

Revision 0

May 29, 1998

4.6.1.8 Logic Diagram. Refer to Figures 4-1 and 4-2.

\subsubsection{Requirements References.}

- TWRS Privatization RFPs, DE-RP06-96RL13308 (RL 1996d)

- FY 1999 Project Breakdown Summary RLTW-07. 
DOE/RL-97-55

Revision 0

May 28, 1998

\section{Advanced Reactors Transition Project}

Concurrence: Original signed by J. E. Meecca

J. E. Mecca,

Division Director,

Transition Programs Division,

U.S. Department of Energy,

Richland Operations Office
Approved by: Orig signed by P. M, Knollmeyer

P. M. Knollmeyer, Assistant Manager,

Office of Assistant Manager for Facility Transition, U.S. Department of Energy, Richland Operations Office 


\subsection{ART PROJECT}

The ART Project mission is to manage and deactivate the FFTF and FMEF, the Nuclear Energy Legacy alkali metal test facilities, and the Plutonium Recycle Test Reactor (PRTR)/309 Building. The FFTF is being maintained in a standby condition, pending a DOE decision on the potential for a future mission, and only limited deactivation is being performed.

The ART Project scope includes all activities needed to (1) maintain the facilities within their approved safety envelope, (2) disposition radioactive and nonradioactive $\mathrm{Na}$ from the designated facilities, (3) remove nuclear materials from the FFTF, (4) remove spent nuclear fuel from the FFTF, (5) remove or stabilize and characterize hazardous and radioactive materials in the designated facilities, (6) make useable facilities available for alternative uses, and (7) establish non-useable facilities in a condition requiring minimal S\&M during the interim period until final D\&D is accomplished. In accomplishing this scope, the ART Project will perform the following activities.

- Protect the health and safety of the public, workers, and the environment.

- Maintain compliance with ES\&H codes and standards during deactivation and establish a safe and environmentally secure configuration that is easily maintained until final D\&D.

- Maintain safe, secure, and compliant storage of SNM/NM/NF.

- Conduct work in accordance with the Tri-Party Agreement; local, national, international, and other agreements; and in compliance with applicable federal, state, and local laws:

- Develop detailed facility deactivation plans, end point criteria, and regulatory documentation.

- Implement cost-effective, innovative approaches to ensure the required safety envelope is defined and maintained during deactivation.

- Complete deactivation and turnover of subprojects within approved baseline schedules.

- Apply lessons learned from other deactivation projects.

- Seek beneficial uses for facilities, equipment, and materials (all types) and resources. 
DOE/RL-97-55

Revision 0

May 28, 1998

\subsubsection{Project Description Summary}

The ART Project consists of three subprojects: FFTF and the Fuels and Materials Examination Facility (FMEF); the Nuclear Energy Legacies; and the Plutonium Recycle Test Reactor (PRTR)/309 Building.

On December 15, 1993, the DOE directed that FFTF be placed in a radiologically and industrially safe shutdown condition. Accordingly, removal of the fuel from the reactor vessel began in March 1994 and was completed in April 1995. Following this major accomplishment, the washing of Na-wetted fueled components was successfully demonstrated.

In parallel with these shutdown activities, procurement contracts were placed for the fabrication of interim storage casks (ISC) and core component containers (CCC) that are being used for the dry storage of washed FFTF nuclear-fueled components. The CCC, when filled with up to seven clean FFTF fueled components, is placed inside an ISC and transported to the 400 Area ISA in the northeast corner of the FFTF Complex.

After preparations were made to support the early draining of the secondary loop $\mathrm{Na}$ to in-plant storage tanks in November 1995, the DOE ordered all drain activities delayed while an expedited review was conducted on the possible benefits of continued reactor operation for tritium production. Eventually, the DOE suspended the plans to drain the secondary loop $\mathrm{Na}$ and deferred all activities that affected the potential restart of the reactor. In January 1997, the Secretary of Energy, by Memorandum of Decision (MOD), directed the FFTF be maintained in a standby condition to permit the DOE to decide by December 1998 on the selection of the primary, long-term source of tritium. The MOD identifies two options for producing tritium: building an accelerator or converting a commercial reactor with the FFTF considered as either a backup or an interim source of tritium. Despite these delays to the shutdown plan, significant progress has been made in several key areas, including packaging and storing of highly radioactive spent fuel components in ISCs, preparing procedures for draining plant $\mathrm{Na}$, completing the reactor vessel plenum drill development project, and completing the construction of the Sodium Storage Facility. The new Sodium Storage Facility, next to the FFTF, has a total tank volume of 1,105 kI which is sufficient to store all of the drainable radioactive $\mathrm{Na}$.

The purpose of the FFTF Transition Project is to prepare FFTF for D\&D, should a decision be made to continue shutdown activities. Pending that decision, the FFTF is being maintained in a standby condition in accordance with HNF-SD-FF-SSP-056, Fast Flux Test Facility Standby Plan (Griffin 1998). Shutdown will be accomplished by establishing a passively safe, low-cost, stable, and environmentally secure configuration of the FFTF plant that can be preserved for several decades. The project removes reactor fuel, dispositions unirradiated fuel, washes and dry-cask stores irradiated fuel, shuts down auxiliary systems, drains the $\mathrm{Na}$ and sodium-potassium alloy ( $\mathrm{NaK}$ ) systems, establishes safe conditions for the $\mathrm{Na}$ residuals, and converts the bulk $\mathrm{Na}$ into a form suitable for disposition. Ancillary support facilities within the FFTF fence line, which no longer provide a useful function, will be deactivated. During deactivation, the appropriate safety envelope will be maintained to ensure deactivation takes place in a safe and regulatory-compliant manner. 
The FFTF Transition Project objectives are as follows.

- Deactivate FFTF in accordance with WHC-SD-FF-SSP-004, Fast Flux Test Facility (FFTF) Stabilization Project Plan (Hulvey 1996). When the deactivation activities are complete, and the final shutdown state is achieved, FFTF shall be unoccupied and locked. All equipment shall be shut down and deactivated, with the exception of maintaining an inert gas supply system, minimal lighting and ventilation, and some fire protection equipment to support periodic surveillance. The bulk Na may still be in storage in the Sodium Storage Facility, pending conversion to a disposable form.

- Convert the stored, radioactive $\mathrm{Na}$ to a reuseable or disposable form in a Sodium Reaction Facility which will be constructed and operated by the FFTF Transition Project or a follow-on project.

- Complete FFTF transition using a two-phase turnover process to the ERC. The first phase is turnover of FFTF and its support facilities, and the second phase is turnover of the Sodium Storage Facility and Sodium Reaction Facility.

- Establish a safe and environmentally secure configuration for the plant that can be maintained for at least 20 years.

- Implement cost-effective deactivation approaches while ensuring the required safety envelope is defined and maintained during deactivation. Until $\mathrm{Na}$ draining is complete, most of the S\&M activities must be continued to maintain FFTF in a safe condition, supporting worker health and safety, environmental requirements, and DOE Order compliance. As FFTF systems and equipment are deactivated, these S\&M activities shall be gradually reduced to a minimal level required for long-term, low-cost S\&M while the facility is awaiting D\&D.

- Maintain compliance with ES\&H codes and standards during deactivation.

- Involve stakeholders as required in the development and execution of the FFTF Transition Project.

- Develop final specific end point criteria for turnover to the ERC. Conduct detailed discussions with the ERC to develop criteria regarding the disposition of alkali metal residuals remaining following the drain activities.

- Apply lessons learned from previous liquid metal reactor and commercial deactivation experience.

- Meet Tri-Party Agreement and DOE FFTF transition milestones.

The FMEF mission is to provide $S \& M$ as necessary to maintain this facility in its present condition until other beneficial uses are found. 
The Nuclear Energy Legacy mission is to disposition nonradioactive alkali metal research facilities at the Hanford Site. The Nuclear Energy Legacies consist of non-nuclear facilities used to support the development of the Liquid Metal Fast Breeder Reactor programs and engineering studies. Some of the facilities contained $\mathrm{Na}$ test loops used to study properties of $\mathrm{Na}$ heat transport systems and investigate behavior of mechanical components that would be operated in an $\mathrm{Na}$ environment. Other facilities were used to train the FFTF operators before the FFTF became operational. The primary systems and equipment remaining to be deactivated are at the 337 Highbay in the 300 Area. Sodium test facilities in the 100-DR and 200 Areas have been removed.

Disposition of the $\mathrm{Na}$ test loops involves preparation of engineering studies to determine the preferred method for deactivation of each specific facility (or facility portion), providing documentation to support $\mathrm{Na}$ test loop disposition, and coordination and performance of $\mathrm{Na}$ test loop and facility deactivation field activities. The project removes remaining $\mathrm{Na}$ and equipment, and other hazards or hazardous chemicals that may exist within the facilities. However, this project does not remove or deactivate building utility systems, except as necessary to disposition the Na test loops. During deactivation, all aspects of the safety envelope will be continually evaluated, and appropriate requirements maintained to ensure activities take place in a safe and regulatory-compliant manner.

The high-level Nuclear Energy Legacy objectives include the following.

- Remove piping systems and test loops.

- Perform necessary equipment and facility modifications required to heat the various $\mathrm{Na}$ storage tanks to allow transfer of the $\mathrm{Na}$ to acceptable DOT containers or transport vehicles.

- Transfer NaK from closed systems into acceptable DOT containers for shipment.

- Remove non-Na equipment from test systems.

- Disposition removed materials and equipment, making them available for other beneficial uses or providing appropriate treatment and disposal.

- Perform S\&M as necessary to ensure safe, compliant storage of $\mathrm{Na}$ and equipment until final disposition.

The 309 Building Deactivation Project mission is to establish a passively safe and environmentally secure configuration for long-term S\&M. Once these conditions have been established, the facility will be turned over to the ERC for S\&M until such time as D\&D can be performed. The project removes, reduces, and/or stabilizes the major remaining radioactive and chemical hazards within the 309 Building and configures the facility for minimal S\&M. There will be no active systems or utilities within the process, laboratory, and office areas. During deactivation, all aspects of the safety envelope will be continually evaluated, and appropriate 
DOE/RL-97-55

Revision 0

May 28, 1998

requirements maintained to ensure deactivation takes place in a safe and regulatory-compliant manner. Stakeholders will be actively involved during deactivation.

The high-level 309 Building Deactivation Project objectives include the following.

- Characterize and clean up or stabilize radiologically controlled areas and hazardous materials.

- Systematically shut down and secure the facility systems consistent with the programmatic, operational, and safety needs of the facility.

- Establish a structurally sound facility boundary including sound roofing to preclude weather or animal entry during interim S\&M.

\subsubsection{Geographic Requirements/Assumptions}

\section{South 600 Area}

\section{Requirements:}

- None.

Planning Assumptions: The 300 Area waste sites, materials, and facilities will be remediated to allow industrial and economic diversification opportunities. The federal government will retain ownership of land in and adjacent to the 300 and 400 Areas, but will lease land for private and public uses to support regional industrial and economic development. Excess land within the 1100 Area will be targeted for transition to non-federal ownership.

The FFTF Transition Project supports this geographic end state by placing the FFTF in the 400 Area into an industrially and radiologically safe state for long-term S\&M pending final D\&D. This will be achieved through the following actions.

- Perform reactor defueling, unirradiated fuel washing and disposition, and irradiated fuel washing and dry cask storage.

- Drain $\mathrm{Na}$ and $\mathrm{NaK}$ systems and accommodate $\mathrm{Na}$ residuals, perform auxiliary systems shutdown, and convert bulk $\mathrm{Na}$ to a form suitable for disposition.

- Remove and/or stabilize hazardous, radioactive, and NM to ensure long-term safety and regulatory compliance, and enable subsequent successful D\&D.

- Turn off water and electricity in deactivated facilities. 
DOE/RL-97-55

Revision 0

May 28, 1998

The FMEF S\&M will support this geographic end state by continuing to maintain the facility until another mission is identified which will use the facility for either government or private industry purposes.

The Nuclear Energy Legacies support this geographic end state by removing alkali metals from the 300 Area. This will make the 337 Highbay Building and the 335 Building available for alternative use in support of industrial and economic diversification opportunities.

The PRTR/309 Building deactivation will support this geographic end state by placing the building in a minimum cost, industrially and radiologically safe S\&M mode pending final D\&D. Final D\&D and remediation will free this 300 Area land for industrial and economic diversification opportunities.

\subsubsection{Material and Waste Flow Requirements/Assumptions}

\section{Requirements:}

- None.

\section{Planning Assumptions:}

\section{Nuclear Materials}

The FFTF legacy NM includes approximately $338 \mathrm{~kg}$ of depleted $U$ from shielding and 376 fuel components. The 376 fuel components consist of 32 mixed-oxide, unirradiated (green) fuel components; $1 \mathrm{Na}$-bonded green fuel component; $8 \mathrm{Na}$-bonded highly irradiated fuel components; 14 mixed-oxide, slightly irradiated fuel components; 28 mixed-oxide, highly irradiated fuel components, which will decay to the slightly irradiated category by 2046; and 293 mixed-oxide fuel components, which are highly irradiated and will remain in that category beyond 2046. The FFTF also stores the TRIGA reactor fuel in the 400 Area ISA.

These NMs will be dispositioned as follows.

- The unirradiated fuel and the components that will be in the slightly irradiated category by 2046 will be transferred to the PFP for secure storage, unless they are needed for future FFTF operation.

- The two fuel assemblies that had leaked will be processed in the Interim Examination and Maintenance Cell, then packaged in ISCs with other FFTF SNF for storage in the 400 Area ISA.

- The 400 Area ISA, including the highly irradiated FFTF fuel packaged in ISCs and the TRIGA fuel, will be transferred to the SNF Project for interim management pending transfer to a permanent repository. 
DOE/RL-97-55

Revision 0

May 28, 1998

- The Na-bonded metal fuel assemblies will be shipped to the INEEL for consolidation with other DOE metal fuel.

- Approximately $338 \mathrm{~kg}$ of depleted U shielding, stored in the 400 Area, will be transferred to the Solid Waste Management Project for burial as radioactive LLW.

\section{Alkali Metals}

The $984 \mathrm{~kL}$ of radioactive FFTF Na coolant will be drained to the Sodium Storage Facility when no longer needed for future FFTF operations. A Sodium Reaction Facility will be designed and constructed at a future date to convert the $\mathrm{Na}$ to caustic for use in processing HLWs at TWRS, or into a disposable compound for burial as radioactive LLW.

The Nuclear Energy Legacy nonradioactive Na, approximately $11.6 \mathrm{~kL}$, will be packaged and shipped to offsite commercial users. The tanks and components will then be cleaned using the nitrogen-water vapor process with the resulting caustic being used by the 300 Area ETF. Rinse water from the final rinse of these components will be sampled for $\mathrm{pH}$ and discharged to the 300 Area process sewer. Approximately $500 \mathrm{~L}$ of nonradioactive $\mathrm{NaK}$ will be dispositioned in a similar manner.

\section{Radiological Wastes}

The FFTF and the 309 Building/PRTR will generate, or collect and package, solid and liquid radioactive LLWs. The solid wastes will be packaged and transferred for burial. The liquid wastes will be packaged and transferred for treatment and disposal.

The FFTF will generate a small amount of mixed hazardous waste, contaminated $\mathrm{Na}$ collected in the Interim Examination and Maintenance Cell, which will be packaged and shipped to the CWC for interim storage pending final disposal.

The 309 Building/PRTR may also collect a small amount of TRU waste, which will be packaged and transferred to the CWC for interim storage pending final repository disposal.

\subsubsection{Facility Life-Cycle Requirements/Assumptions}

\section{Requirements:}

- None.

Planning Assumptions: A facility assignment matrix showing facility ownership assignment for life-cycle phases is shown in the following table. The life-cycle phases are those identified in DOE Order 430.1, Life-Cycle Asset Management (DOE 1995c). 
DOE/RL-97-55

Revision 0

May 28, 1998

\begin{tabular}{|c|c|c|c|c|c|c|c|c|c|}
\hline \multirow{3}{*}{ Complex/facility } & \multicolumn{9}{|c|}{ Life cycle } \\
\hline & \multirow{2}{*}{$\begin{array}{l}\text { Program } \\
\text { planning }\end{array}$} & \multirow[b]{2}{*}{ Preconceptual } & \multirow[b]{2}{*}{ Conceptual } & \multicolumn{3}{|c|}{ Execute } & \multirow{2}{*}{$\begin{array}{c}\text { Ops and } \\
\text { maint }\end{array}$} & \multicolumn{2}{|c|}{ Close out } \\
\hline & & & & Design & Construct & Turnover & & $\begin{array}{c}\text { Post- } \\
\text { operation }\end{array}$ & $\mathrm{D} \& \mathrm{D}$ \\
\hline $\begin{array}{l}\text { Fast Flux Test } \\
\text { Facility }\end{array}$ & RL-TP11 & - & - & - & - & - & $\begin{array}{l}\mathrm{RL} \\
\mathrm{TP11}\end{array}$ & RL-TP11 & RL-ER06 \\
\hline $337 \mathrm{~B} / 335$ & RL-TP11 & - & - & - & - & - & - & RL-TP11 & RL.TP14 \\
\hline 309/PRTR & RL-TP11 & - & - & - & -- & - & - & RL-TP11 & RL-ER06 \\
\hline
\end{tabular}

$\mathrm{D} \& \mathrm{D}=$ decontamination and decommissioning

\subsubsection{Project Safety Authorization Basis/NEPA and Permits}

The Authorization Basis for FFTF is contained in WHC-TI-75002 (Vol. 1-10)

(Gantt 1997) and WHC-SD-FF-SAR-007 (Gantt 1993). Deactivation activities shall be evaluated against the approved safety basis to identify any potential USQs. If the activity is covered by the analysis in the safety basis, no additional safety basis documentation or evaluation is required. If the activity is not covered, either the work plans must be modified to stay within the bounds of the existing safety basis or the safety basis must be modified through additional safety analyses. Once approved by RL, the new analysis shall become part of the approved safety basis.

Environmental, safety, and health requirements for FFTF are contained in WHC-SD-MP-SRD-006, Fast Flux Test Facility Standards Requirements Identification Document (Hisaw 1996). The potential environmental impacts of the FFTF deactivation have been reviewed and documented in DOE/EA-0993, Environmental Assessment: Shutdown of the Fast Flux Test Facility, Hanford Site, Richland, Washington (DOE 1995k).

The remaining facilities in the ART Project are all non-nuclear facilities and do not require a safety Authorization Basis. However, potential safety hazards to the public and worker have been evaluated and will be controlled during the deactivation process.

The management and disposition of Nuclear Energy Legacy nonradioactive $\mathrm{Na}$ inventories and associated facilities shall be in accordance with WHC-SD-FF-MP-001, Hanford Site Sodium Management Plan (Guttenberg 1995) and DOE/EA-0987, Environmental Assessment: Disposition of Alkali Metal Test Loops, Hanford Site, Richland, Washington (DOE 19951). Additional safety evaluations are documented in WHC-SD-PRP-HA-020, 300 Area Sodium Storage Facilities Hazards Assessment (Campbell 1996) and HNF-SD-NEL-ASA-002, Hazard Baseline Documentation and Auditable Safety Analysis of the 3718-M Sodium Transfer Operation in 337 Building Highbay (Brehm 1997). 
Evaluations related to the 309 Building are contained in WHC-SD-SP-PHA-001, PRTR/309 Building Nuclear Facility Preliminary Hazards Assessment (Cornwell 1994) and WHC-SD-NEL-HIE-001, 309 Building Fire Protection Analysis and Justification for Deactivation of Sprinkler System (Conner 1996). The 309 Building transition has also been subjected to a NEPA review and has been determined to be covered by a categorical exclusion (Farabee 1995).

\subsubsection{Other Requirements and Planning Assumptions}

\section{Requirements:}

- None.

\section{Planning Assumptions:}

- FFTF: FFTF is currently in a standby mode while being considered for a future production mission.

- The Maintenance and Storage Facility (437), Maintenance Facility (4713-B), and Operations Support Building (4710) are not included in the scope of FFTF deactivation. These will remain available to support other Hanford Site missions. The Water Pump Houses (481 and 481-A), Water Storage Tanks, and wells will remain in operation. Electrical services to deactivated buildings may be switched off, but the system will remain operational to serve the 400 Area.

- Nuclear Energy Legacies: The deactivation of the legacy facilities is necessary to complete the DOE activities in the Hanford Site 300 Area.

- PRTR/309 Building: The deactivation of the PRTR/309 Building is necessary to complete the DOE activities in the Hanford Site 300 Area.

- The Interim Examination and Maintenance Mockup Cell in the 309 Building will be dispositioned in accordance with the needs of FFTF.

\subsubsection{Interfaces}

\begin{tabular}{|l|c|l|}
\hline \multicolumn{1}{|c|}{ Project title } & Project number & \multicolumn{1}{c|}{ Interface } \\
\hline $\begin{array}{l}\text { Solid Waste Storage \& } \\
\text { Disposal }\end{array}$ & RL-WM03 & For disposition of LLW and TRU waste \\
\hline Liquid Waste Program & RL-WMO5 & For disposition of liquid effluents \\
\hline Analytical Services & RL-WM-06 & For sample analysis and other laboratory support \\
\hline
\end{tabular}


DOE/RL-97-55

Revision 0

May 28, 1998

\begin{tabular}{|l|c|l|}
\hline \multicolumn{1}{|c|}{ Project title } & Project number & \multicolumn{1}{|c|}{ Interface } \\
\hline $\begin{array}{l}\text { Management and Economic } \\
\text { Transition Division }\end{array}$ & -- & $\begin{array}{l}\text { To seek beneficial uses for excess materials, equipment, and } \\
\text { facilities }\end{array}$ \\
\hline Landlord & RL-TP13 & $\begin{array}{l}\text { To supply infrastructure support and accept sanitary waste and } \\
\text { other landfill waste materials. The 400 Area sanitary waste is } \\
\text { processed by the Washington Public Power Supply System } \\
\text { Nuclear Plant 2. }\end{array}$ \\
\hline HAMMER & RL-HM01 & For personnel training support \\
\hline SNF Project & RL-WM01 & $\begin{array}{l}\text { To establish criteria for storage of FFTF fuel and for 400 Area } \\
\text { ISA operations in anticipation of the 400 Area ISA and FFTF } \\
\text { fuel stored there being turned over to the SNF Project when the } \\
\text { FFTF fuel processing has been completed }\end{array}$ \\
\hline $\begin{array}{l}\text { Hanford Surplus Facilities } \\
\text { Program 300 Area } \\
\text { Revitalization Project }\end{array}$ & RL-TP14 & $\begin{array}{l}\text { To turn over 300 Area facilities once the sodium systems have } \\
\text { been deactivated }\end{array}$ \\
\hline S\&M & RL-ER05 & $\begin{array}{l}\text { To transfer deactivated facilities ready for long-term S\&M and/or } \\
\text { D\&D }\end{array}$ \\
\hline
\end{tabular}

D\&D = decontamination and decommissioning

FFTF $\quad=$ Fast Flux Test Facility

HAMMER $=$ Hazardous Materials Management and Emergency Response

ISA $=$ Interim Storage Area

LLW = low-level waste

S\&M = surveillance and maintenance

SNF $\quad=$ spent nuclear fuel

TRU = transuranic

\subsubsection{Logic Diagram}

Advanced Reactors Transition deactivation and Na management plans contain the overall approach that will be followed to deactivate facilities and manage bulk $\mathrm{Na}$. Advanced Reactors Transition schedules capture the logical relationships between project activities.

\subsubsection{Requirements References}

- WHC-SD-MP-SRID-006, Fast Flux Test Facility Standards Requirements Identification Document (Hisaw 1996)

- DOE/EA-0987, Environmental Assessment: Disposition of Alkali Metal Test Loops, Hanford Site, Richland, Washington (DOE 19951)

- DOE/EA-0993, Environmental Assessment: Shutdown of the Fast Flux Test Facility, Hanford Site, Richland, Washington (DOE 1995k) 
DOE/RL-97-55

Revision 0

- HNF-SD-FF-SSP-056, FFTF Standby Project Plan (Griffin 1998)

- HNF-SD-NEL-ASA-002, Hazard Baseline Documentation and Auditable Safety Analysis of the 3718-M Sodium Transfer Operation in 337 Building Highbay (Brehm 1997)

- WHC-SD-FF-MP-001, Hanford Site Sodium Management Plon (Guttenberg 1995)

- WHC-SD-PRP-HA-020, 300 Area Sodium Storage Facilities Hazards Assessment (Campbell 1996)

- WHC-SD-SP-PHA-001, PRTR/309 Building Nuclear Facility Preliminary Hazards Assessment (Cornwell 1994)

- WHC-SD-NEL-HIE-002, Radiological Consequences of a Postulated Fire in the 309 Building (Himes 1996)

- WHC-TI-75002, Fast Flux Test Facility Final Safety Analysis Report, Amendment 77 (Gantt 1997)

- WHC-SD-SP-DB-002, D\&D Facility Acceptance Criteria for 309 Building (Graves 1994)

- WHC-SD-SP-SSP-001, 309 Building Transition Plan (Bitten 1995).

\subsubsection{Issues}

None. 
DOE/RL-97-55

Revision 0

\subsection{REFERENCES}

10 CFR 20, "Standards for Protection Against Radiation;" Code of Federal Regulations, as amended.

10 CFR 61, "Licensing Requirements for Land Disposal of Radioactive Waste," Code of Federal Regulations, as amended.

10 CFR 400-499, "Subchapter D--Energy Conservation," Code of Federal Regulations, as amended.

10 CFR 800, "Loans for Bid or Proposal Preparation by Minority Business Enterprises Seeking DOE Contracts and Assistance," Code of Federal Regulations, as amended.

10 CFR 830, "Nuclear Safety Management," Code of Federal Regulations, as amended.

10 CFR 830.120, "Quality Assurance Requirements," Code of Federal Regulations, as amended.

10 CFR 834, "Radiation Protection for Public and Environment," Code of Federal Regulations, as amended.

10 CFR 835, "Radiation Protection for Occupational Workers," Code of Federal Regulations, as amended.

10 CFR 962, "By-Product Material," Code offFederal Regulations, as amended.

10 CFR 1022, "DOE Floodplain and Wetlands Procedures," Code of Federal Regulations, as amended.

29 CFR 1910, "Occupational Safety and Health Standards," Code of Federal Regulations, as amended.

$40 \mathrm{CFR}$, "Protection of the Environment," Code of Federal Regulations, as amended.

40 CFR 50, "National Primary and Secondary Ambient Air Quality Standards," Code of Federal Regulations, as amended.

40 CFR 61, "National Emission Standards for Hazardous Air Pollutants," Code of Federal Regulations, as amended.

40 CFR 121, "National Pollutant Discharge Elimination System (NPDES) Permitting Program," Code of Federal Regulations, as amended.

40 CFR 141, "National Primary Drinking Water Regulations," Code of Federal Regulations, as amended. 
DOE/RL-97-55

Revision 0

40 CFR 191, "Environmental Radiation Protection Standards for Management and Disposal of Spent Nuclear Fuel, High-Level and Transuranic Radioactive Wastes," Code of Federal Regulations, as amended.

40 CFR 247, "Comprehensive Procurement Guideline for Products Containing Recovered Materials, Code of Federal Regulations, as amended.

40 CFR 261, "Identification and Listing of Hazardous Waste," Code of Federal Regulations, as amended.

40 CFR 264, "Standards for Owners and Operators of Hazardous Waste Treatment, Storage, and Disposal Facilities," Code of Federal Regulations, as amended.

40 CFR 265, "Interim Status Standards for Owners and Operators of Hazardous Waste Treatment, Storage, and Disposal Facilities," Code of Federal Regulations, as amended.

40 CFR 268, "Land Disposal Restrictions, " Code of Federal Regulations, as amended.

40 CFR 761, "Polychlorinated Biphenyls (PCBs) Manufacturing, Processing, Distribution in Commerce, and Use Prohibitions," Code of Federal Regulations, as amended.

40 CFR 761.70, "Incineration of PCBs and PCB Items," Code of Federal Regulations, as amended

49 CFR, "Transportation," Code of Federal Regulations, as amended.

49 CFR 100-177, "Hazardous Materials Transportation," Code of Federal Regulations, as amended.

49 CFR 171-179, "Hazardous Materials Regulations," Code of Federal Regulations, as amended.

49 CFR 210-240, "Federal Railroad Administration," Code of Federal Regulations, as amended.

53 FR 12449, "Disposal of Hanford Defense High-Level, Transuranic, and Tank Wastes, Hanford Site, Richland, Washington; Record of Decision," Federal Register, April 14, 1988.

60 FR 31115, "Hazardous Waste Management System: Identification and Listing of Hazardous Wastes: Final Exclusion," Federal Register, June 13, 1995.

Adler, J. G., 1994, 303K Storage Facility Closure Plan, DOE/RL-90-04, Rev. 2, U.S. Department of Energy, Richland Operations Office, Richland, Washington.

AEC-RL, 1970, Policy Statement Regarding Solid Waste Burial, Immediate Action Directive No. 0511-21, U.S. Atomic Energy Commission, Richland, Washington. 
DOE/RL-97-55

Revision 0

Aguirre, H., Jr., 1995, 242-A Evaporator/Crystallizer Final Safety Analysis Report, WHC-SD-WM-SAR-023, Rev. 2, Westinghouse Hanford Company, Richland, Washington.

ANSI, 1989, Manual on Uniform Traffic Control Devices, ANSI-D6.1E-1989, American National Standards Institute, New York, New York.

ASME/ANSI, 1994, Quality Assurance Requirements for Nuclear Facility Applications, ANSI/ASME NQA-1-1994-IA, American National Standards Institute, American Society of Mechanical Engineers, New York, New York.

Asphalt, 1977, Asphalt in Pavement Maintenance, MS-16, The Asphalt Institute, College Park, Maryland.

Atomic Energy Act of 1954, 42 USC 2011, et seq.

Ballantyne, N. A., 1993, Federal Register Notice of U.S. EPA Approval of the 200 Area Effluent Treatment Facility Delisting Petition, DOE/RL-92-72, Richland Operations Office, Richland, Washington.

Bendixsen, R. B, 1995, Solid Waste Burial Grounds Interim Safety Basis, WHC-SD-WM-ISB-002, Westinghouse Hanford Company, Richland, Washington.

Benecke, M. W., 1995a, Interim Safety Basis for Fuel Supply Shutdown Facility, WHC-SD-NR-ISB-001, Rev. OB, Westinghouse Hanford Company, Richland, Washington.

Benecke, M. W., 1995b, Fuel Supply Shutdown Facility Interim Operational Safety Requirements, WHC-SD-NR-TSR-001, Rev. 0, Westinghouse Hanford Company, Richland, Washington.

Berneski, L. D., 1995, Hanford 300 Area Retention Process Sewer Inventory at Risk Calculations and Safety Analysis, WHC-SD-WM-SAD-027, Rev. 0, Westinghouse Hanford Company, Richland, Washington.

Benton-Franklin-Walla Walla Counties Air Pollution Control Authority, General Regulation 80-7.

Biebesheimer, E., 1996, Tank Waste Remediation System Standards/Requirements Identification Document, WHC-SD-MP-SRID-001, Rev. 1-B, Westinghouse Hanford Company, Richland, Washington.

Bitten, E. J., 1995, 309 Building Transition Plan, WHC-SD-SP-SSP-001, Rev. 1, Westinghouse Hanford Company, Richland, Washington.

Bodily, D. B., 1993, Nonradioactive Dangerous Waste Storage Facility, WHC-SD-WM-SAR-019, Westinghouse Hanford Company, Richland, Washington. 
Bonner, A. L., 1995, Enhanced Radioactive and Mixed Waste Storage Phase V (Project W-112) Safety Assessment, WHC-SD-W112-SAD-001, Rev. 0, Westinghouse Hanford Company, Richland, Washington.

Brehm, W. F., 1997, Hazard Baseline Documentation and Auditable Safety Analysis of the 3718$M$ Sodium Transfer Operation in 337 Building Highbay, HNF-SD-NEL-ASA-002, Rev. 0, prepared by B\&W Hanford Company for Fluor Daniel Hanford, Inc., Richland, Washington.

Brown, T. M., 1998, Tank Characterization Technical Sampling Basis, HNF-SD-WM-TA-164, Rev. 4, Lockheed Martin Hanford Corporation for Fluor Daniel Hanford, Inc., Richland, Washington.

Burbank, D., 1997, Design Requirements Document for ILAW Interim Storage, HNF-SD-465-DRD-001, Rev. 0, SGN Eurisys Services Corporation for Fluor Daniel Hanford, Inc., Richland, Washington.

Cain, F. G., 1995, Central Waste Complex - Interim Safety Basis, WHC-SD-WM-ISB-007, Rev. 0, Westinghouse Hanford Company, Richland, Washington.

Calmus, R. B., 1996, Design Requirements Document for the Interim Storage Phase I Solidified High-Level Waste Function 4.2.4.1.2, WHC-SD-WM-DRD-012, Rev. 0, Westinghouse Hanford Company, Richland, Washington.

Calmus, R. B., 1996e, Statement of Work for Conceptual Design of High-Level Waste Interim Storage System Project (Phase I), HNF-SD-W464-SOW-001, Rev. 0, SGN Eurisys Services Corporation and Lockheed Martin Hanford Corporation for Fluor Daniel Hanford, Inc., Richland, Washington.

Campbell, L. R., 1996, 300 Area Sodium Storage Facilities Hazards Assessment, WHC-SD-PRP-HA-020, Rev, 1, Westinghouse Hanford Company, Richland, Washington.

Carlson, T. A., 1995, Waste Receiving and Processing Module $2 A$ Termination of Design Closeout Report, WHC-SD-W100-RPT-001, Rev. 0, Westinghouse Hanford Company, Richland, Washington.

Cartmell, D. B., 1996, Facility Stabilization Project Fiscal Year 1997 Multi-Year Work Plan (MYWP) for WBS 7.1, WHC-SP-1 126, Rev. 2, Westinghouse Hanford Company, Richland, Washington.

Chalk, S. E., 1996a, B Plant Interim Safety Basis, WHC-SD-WM-ISB-008, Rev. 0, Westinghouse Hanford Company, Richland, Washington.

Chalk, S. E., 1996b, B Plant Interim Safety Basis Accident Analysis, WHC-SD-WM-SARR-030, Rev. 0, Westinghouse Hanford Company, Richland, Washington. 
Chalk, S. E., 1996c, B Plant Facility Description, WHC-SD-WM-TM-004, Rev. 1, Westinghouse Hanford Company, Richland, Washington.

Chalk, S. E., 1997, Liquid Effluent Retention Facility Final Hazard Category Determination, HNF-SD-WM-SAD-040, Rev. 0, Fluor Daniel Northwest, Inc., for Fluor Daniel Hanford, Inc., Richland, Washington.

Cillan, M. R., 1993, Hazard Classification for the Thermal Treatment Facility, Project W-242, WHC-SD-W242-HC-001, Rev. 0, Westinghouse Hanford Company, Richland, Washington.

Clean Air Act of 1955, as amended, 42 USC 7401, et seq

Comprehensive Environmental Response, Compensation, and Liability Act of 1980 , 42 USC 9601 , et seq.

Conner, R. P., 1997, 309 Building Fire Protection Analysis and Justification for Deactivation of Sprinkler System, WHC-SD-NEL-HIE-001, Rev. 1, B\&W Hanford Company, Richland, Washington.

Cornwell, B. C., 1994, PRTR/309 Building Nuclear Facility Preliminary Hazards Assessment, WHC-SD-SP-PHA-001, Rev. 0, Westinghouse Hanford Company, Richland, Washington.

Courson, D. B., 1994, PFP Transition Project Mission Analysis Report, WHC-SD-CP-MAR-001, Rev. 0, Westinghouse Hanford Company, Richland, Washington.

Covey, L. I., 1996, Waste Encapsulation and Storage Facility Safety Analysis Report, WHC-SD-WM-SAR-005, Rev. 12, Westinghouse Hanford Company, Richland, Washington.

Curry, L. R., 1997, ERC Hazard Classification Matrices for Above Ground Structures and Groundwater and Soil Remediation Activities, BHI-00981, Rev. 0, Bechtel Hanford, Inc., Richland, Washington.

DNFSB, 1990, Savannah River Site Operator Training, Recommendation 90-1, Defense Nuclear Facilities Safety Board, Washington, D.C.

DNFSB, 1992a, Facility Representatives, Recommendation 92-2, Defense Nuclear Facilities Safety Board, Washington, D.C.

DNFSB, 1992b, Training and Qualification, Recommendation 92-7, Defense Nuclear Facilities Safety Board, Washington, D.C.

DNFSB, 1992c, Multi-Function Waste Tank Facility at Hanford Site, Recommendation 92-4, Defense Nuclear Facilities Safety Board, Washington, D.C. 
DNFSB, 1993a, Hanford Waste Tanks Characterization Studies, Recommendation 93-5, Defense Nuclear Facilities Safety Board, Washington, D.C.

DNFSB, 1993b, Improving DOE Technical Capability in Defense Nuclear Facilities Programs, Recommendation 93-3, Defense Nuclear Facilities Safety Board, Washington, D.C.

DNFSB, 1994a, Conformance with Safety Standards at DOE Low-Level Nuclear Waste and Disposal Sties, Recommendation 94-2, Defense Nuclear Facilities Safety Board, Washington, D.C.

DNFSB, 1994b, Improved Schedule for Remediation in the Defense Nuclear Facilities Complex, Recommendation 94-1, Defense Nuclear Facilities Safety Board, Washington, D.C.

DOE, 1983, Occupational Safety and Health Program for DOE Contractor Employees at Government-Owned Contractor-Operated Facilities, DOE Order 5483.1A, U.S. Department of Energy, Washington, D.C.

DOE, 1985, Safety Requirements for the Packaging and Transportation of Hazardous Material, Hazardous Substances, and Hazardous Waste, DOE Order 5480.3, U.S. Department of Energy, Washington, D.C.

DOE, 1986, Safety Analysis and Review System, DOE Order 5481.1B, U.S. Department of Energy, Washington, D.C.

DOE, 1987, Final Environmental Impact Statement: Disposal of Hanford Defense High-Level, Transuranic, and Tank Wastes, Hanford Site, Richland, Washington, DOE/EIS-0113, Vol. 1 through 5, U.S. Department of Energy, Washington, D.C.

DOE, 1988a, General Environmental Protection Program, DOE Order 5400.1, U.S. Department of Energy, Washington, D.C.

DOE, 1988b, Radiation Protection for Occupational Workers, DOE Order 5480.11, U.S. Department of Energy, Washington, D.C.

DOE, 1988c, Radioactive Waste Management, DOE Order 5820.2A, U.S. Department of Energy, Washington, D.C.

DOE, 1989, General Design Criteria, DOE Order 6430.1A, U.S. Department of Energy, Washington, D.C.

DOE, 1990a, Radiation Protection of the Public and the Environment, DOE Order 5400.5, U.S. Department of Energy, Washington, D.C.

DOE, 1990b, Conduct of Operations Requirements for DOE Facilities, DOE Order 5480.19, U.S. Department of Energy, Washington, D.C. 
DOE/RL-97-55

Revision 0

DOE, 1991a, Unreviewed Safety Questions, DOE Order 5480.21, U.S. Department of Energy, Washington, D.C.

DOE, 1991b, Quality Assurance, DOE Order 5700.6C, U.S. Department of Energy, Washington, D.C.

DOE, 1992a, Nuclear Safety Analysis Reports, DOE Order 5480.23, U.S. Department of Energy, Washington, D.C.

DOE, 1992b, Technical Safety Requirements, DOE Order 5480.22, U.S. Department of Energy, Washington, D.C.

DOE, 1992c, National Environmental Policy Act Compliance Program, DOE Order 5440.1E, U.S. Department of Energy, Washington, D.C.

DOE, 1992d, Environmental Assessment - Hanford Environmental Compliance Project, DOE/EA-0383, U.S. Department of Energy, Washington, D.C.

DOE, 1992e, DOE Standard, Hazard Categorization and Accident Analysis Techniques for Compliance with DOE Order 5480.23, Nuclear Safety Analysis Reports, DOE-STD-1027-92, U.S. Department of Energy, Washington, D.C.

DOE, 1992f, Quality Assurance Requirements and Description for the Civilian Radioactive Waste Management Program, DOE/RW-0333P, Rev. 5, U.S. Department of Energy, Washington, D.C.

DOE, 1993, Fire Protection, DOE Order 5480.7A, U.S. Department of Energy, Washington, D.C.

DOE, 1994a, Protection and Control of Safeguards and Security Interests, DOE Order 5632.1C, U.S. Department of Energy, Washington, D.C.

DOE, 1994b, Maintenance Management Program, DOE Order 4330.4B, U.S. Department of Energy, Washington, D.C.

DOE, 1994c, Personnel Selection, Training, and Staffing Requirements at DOE Reactor and Non-Reactor Facilities, DOE Order 5480.20A, U.S. Department of Energy, Washington, D.C.

DOE, 1994d, Control and Accountability of Nuclear Materials, DOE Order 5633.3B, U.S. Department of Energy, Washington, D.C.

DOE, 1994e, Management of Nuclear Materials, DOE Order 5660.1B, U.S. Department of Energy, Washington, D.C. 
DOE/RL-97-55

Revision 0

DOE, 1994f, Plan of Action to Resolve Spent Nuclear Fuel Vulnerabilities Phase I,

U.S. Department of Energy, Washington, D.C.

DOE, 1995a, Record of Decision (ROD): Safe Interim Storage of Hanford Tank Wastes,

Hanford Site, Richland, WA, U.S. Department of Energy, Washington, D.C.

DOE, 1995b, Startup and Restart of Nuclear Facilities, DOE Order 425.1, U.S. Department of Energy, Washington, D.C.

DOE, 1995c, Life-Cycle Asset Management, DOE Order 430.1, U.S. Department of Energy, Washington, D.C.

DOE, 1995d, 300 Area Process Sewer Piping Upgrade and 300 Area Treated Effluent Disposal Facility Discharge to the City of Richland Sewer System, Hanford Site, Richland, DOE/EA-0980, U.S. Department of Energy, Washington, D.C.

DOE, 1995e, Characterization of Stored Defense Production Spent Nuclear Fuel and Associated Materials at Hanford Site, Richland, Washington, DOE/EA-1030, U.S. Department of Energy, Washington, D.C.

DOE, 1995f, Facility Deactivation End Points Handbook, draft, U.S. Department of Energy, Office of Environmental Management, Office of Nuclear Material and Facility Stabilization, Germantown, Maryland.

DOE, 1995g, Decommissioning Resource Manual, DOE/EM-0246, Office of Environmental Management, Office of Environmental Restoration, Germantown, Maryland.

DOE, 1995h, Environment, Safety and Health Policy for the U.S. Department of Energy Complex, DOE P 450.1, U.S. Department of Energy, Washington, D.C.

DOE, 1995i, Plutonium Vulnerability Management Plan, DOE/EM-0199 (Attachment B, , DNFSB 94-1 Implementation Plan), U.S. Department of Energy, Washington, D.C.

DOE, 1995j, Environmental Assessment: Deactivation of N Reactor Facilities, Hanford Site, Richland, Washington, DOE/EA-0984, U.S. Department of Energy, Washington, D.C.

DOE, 1995k, Environmental Assessment: Shutdown of the Fast Flux Test Facility, Hanford Site, Richland, Washington, DOE/EA-0993, U.S. Department of Energy, Washington, D.C.

DOE, 19951, Environmental Assessment: Disposition of Alkali Metal Test Loops, Hanford Site, Richland, Washington, DOE/EA-0987, U.S. Department of Energy, Washington, D.C.

DOE, 1996a, Tank Waste Remediation System Final Environmental Impact Statement, DOE/EIS-0189, U.S. Department of Energy, Washington; D.C. 
DOE, 1996b, Memorandum of Understanding, Management of 300 Area Light-Water Reactor Spent Nuclear Fuel (Letter No. 96-STO-033, May 22), U.S. Department of Energy, Washington, D.C.

DOE, 1996c, Memorandum of Understanding for Management of Neutron Radiography Facility Training Reactor, Isotopics, General Atomics Spent Nuclear Fuel (Letter No. 96-SFD127, May 23), U.S. Department of Energy, Washington, D.C.

DOE, 1996d, Memorandum of Understanding for Management of Spent Nuclear Fuel Currently Located at T Plant and the 200 Area Low-Level Burial Grounds (Letter No. 96-SFD-166, July 31 ), U.S. Department of Energy, Washington, D.C.

DOE, 1996e, Memorandum of Understanding for Management of Spent Nuclear Fuel Currently Located at the Plutonium Finishing Plant (Letter No. 96-SFD-171, August 16), U.S. Department of Energy, Washington, D.C.

DOE, 1996f, Management of Spent Nuclear Fuel from the $K$ Basins at the Hanford Site, Richland, Washington (Addendum Final Environmental Impact Statement), DOE/EIS-0245F, U.S. Department of Energy, Washington, D.C.

DOE, 1996g, Plutonium Finishing Plant - Final Environmental Impact Statement, DOE/EIS-0244F, U.S. Department of Energy, Washington, D.C.

DOE, 1996h, Plutonium Fïnishing Plant Stabilization Environmental Impact Statement Record of Decision, 96-EAP-179, U.S. Department of Energy, Washington, D.C.

DOE, 1996i, Criteria for Safe Storage of Plutonium Metals and Oxides, DOE-STD-3013-96, U.S. Department of Energy, Washington, D.C.

DOE, 1996j, Storage and Disposition of Weapons-Usable Fissile Materials Final Programmatic Environmental Impact Statement, DOE/EIS-0229, U.S. Department of Energy, Washington, D.C.

DOE, 1997a, Tank Waste Remediation System Environmental Impact Statement Record of Decision, Hanford Site, Richland, Washington, U.S. Department of Energy, Washington, D.C.

DOE, 1997b, National Environmental Policy Act Compliance Program, DOE Order 451.1A, U.S. Department of Energy, Washington, D.C.

DOE, 1997c, Programmatic Agreement Between Fast Flux Test Facility Project and Spent Nuclear Fuel Project (Letter No. 97-SFD-197), U.S. Department of Energy, Washington, D.C. 
DOE/RL-97-55

Revision 0

DOE, 1997d, Management of Hanford Site Non-Defense Production Reactor Spent Nuclear Fuel, Hanford Site, Richland, Washington, DOE/EA-1185, U.S. Department of Energy, Washington, D.C.

DOE-RL, 1988, Low-Level Burial Grounds Dangerous Waste Permit Application: Request for Exemption from Lined Trench Requirements for Submarine Reactor Compartments, DOE-RL 88-20, Supplement 1, U.S. Department of Energy-Richland Field Office, Richland, Washington.

DOE/RL, 1992, 224-T Transuranic Waste Storage and Assay Facility Dangerous Waste Permit Application, DOE/RL-91-51, U.S. Department of Energy, Richland Operations Office, Richland, Washington.

Duncan, D. R., 1991, Solid Waste Management Program Plan, WHC-EP-0363, Rev. 1, Westinghouse Hanford Company, Richland, Washington.

Dunigan, P., Jr., 1996, Categorical Exclusion for Low-Level Liquid Waste Treatment Facilities Upgrades, Hanford Site, Richland, Washington (Letter No. 9600389 to R.H. Engleman, Westinghouse Hanford Company, February 1), U.S. Department of Energy, Richland Operations Office, Richland, Washington.

Dunkirk, J. H., 1996, Memorandum of Understanding Between Westinghouse Hanford Company and Bechtel Hanford, Inc., July 9, BHI-00888, Rev. 0, Bechtel Hanford, Inc., Richland, Washington.

Ecology, 1995a, State Waste Discharge Permit No. ST 4500, June 26, Washington State Department of Ecology, Olympia, Washington.

Ecology, 1995b, State Waste Discharge Permit No. ST 4502, April 18, Washington State Department of Ecology, Olympia, Washington.

Ecology, 1997, Dangerous Waste Portion of the Resource Conservation and Recovery Act Permit for the Treatment, Storage, and Disposal of Dangerous Waste at the Hanford Facility, Permit No. WA7890008967, Rev. 3A, Washington State Department of Ecology, Olympia, Washington.

Ecology and DOE, 1991, Consent Order DE91NM-177, Washington State Department of Ecology and U.S. Department of Energy, Olympia, Washington.

Ecology, EPA, and DOE, 1996, Hanford Federal Facility Agreement and Consent Order, as amended, Washington Department of Ecology, U.S. Environmental Protection Agency, and U.S. Department of Energy, Richland Operations Office, Olympia, Washington.

Edwards, W. S., 1997, Cask Transportation System, HNF-SD-TP-SARP-017, Rev. 0, Waste Management Northwest for Fluor Daniel Hanford, Inc., Richland, Washington. 
DOE/RL-97-55

Revision 0

ERDA, 1975, Waste Management Operations, Hanford Reservation, Richland, Washington: Final Environmental Statement, ERDA-1538, Vol. 1, U.S. Energy Research \& Development Administration, Washington, D.C.

Executive Order 11988, "Floodplain Management," May 24, 1977, 42 FR 26951, as amended by Executive Order 12148, 44 FR 43239, July 20, 1979.

Executive Order 11990, "Protection of Wetlands," May 24, 1977, 42 FR 26961, as amended by Executive Order 12608, 52 FR 34617, September 9, 1987.

Farabee, O. A., 1995, National Environmental Policy Act (NEPA) Categorical Exclusion for the 309 Building Transition, 300 Area, Hanford Site, Richland, Washington (Letter No. $95-$ FFTF-011 to President, Westinghouse Hanford Company, February 7), U.S. Department of Energy, Richland Operations Office, Richland, Washington.

Federal Environmental Pesticide Control Act of 1972, 7 USC 136, et seq.

Federal Water Pollution Control Act (Clean Water Act), 33 USC 1251, et seq.

FDH, 1997a, Waste Encapsulation and Storage Facility (WESF) Administration Manual, FSP-WESF-5-6, October 1, Fluor Daniel Hanford, Inc., Richland, Washington.

FDH, 1997b, Plutonium Finishing Plant Administration, FSP-PFP-5-8, September 30, Fluor Daniel Hanford, Inc., Richland, Washington.

FDH, 1998a, TWRS Administration, HNF-IP-0842, Fluor Daniel Hanford, Inc., Richland, Washington.

FDH, 1998b, Fuels Supply Operations Control Manual, FSP-FSS-5-35, Fluor Daniel Hanford, Inc., Richland, Washington.

Flyckt, D. L., 1995, 200 Area Effluent Treatment Facility Auditable Safety Analysis, WHC-SD-ETF-ASA-001, Rev. 0, Westinghouse Hanford Company, Richland, Washington.

Fulton, J. C., 1996, Memorandum of Understanding (Between WHC-SNF Project, WHC-TWRS, DOE-AMW and DOE-TWRS), "K Basins Sludge Transfer to Tank Waste Remediation System" (Letter No. 9652070 to C. A. Hansen, Subject: Request for Approval of Second Revision of Memorandum of Understanding, U.S. Department of Energy, Richland Operations Office, May 6), Westinghouse Hanford Company, Richland, Washington.

Galioto, T. M., 1997, 242AL Liquid Effluent Retention Facility Auditable Safety Analysis, HNF-SD-LEF-ASA-002, Rev. 1, Waste Management Federal Services of Hanford, Inc., for Fluor Daniel Hanford, Inc., Richland, Washington. 
DOE/RL-97-55

Revision 0

Gantt, D., 1993, Fuel Storage Facility Final Safety Analysis Report, WHC-SD-FF-SAR-007, Rev. 0, Westinghouse Hanford Company, Richland, Washington.

Gantt, D., 1997, Fast Flux Test Facility Final Safety Analysis Report, Amendment 77, WHC-TI-75002, Vol. 1-10, Westinghouse Hanford Company, Richland, Washington.

Garvin, L. J., 1996, Spent Nuclear Fuel Project Path Forward Additional NRC Requirements, WHC-SD-SNF-DB-003, Rev. 2, Westinghouse Hanford Company, Richland, Washington.

Garvin, L. J., 1997a, Canister Storage Building (CSB) Safety Analysis Report Phase 3: Safety Analysis Documentation Supporting CSB Construction, HNF-SD-SNF-RPT-004, Rev. 7, Fluor Daniel Northwest, Inc., for Fluor Daniel Hanford, Inc., Richland, Washington.

Garvin, L. J, 1997b, Safety Analysis Report for the Cold Vacuum Drying Facility, Phase 1, Supporting Civil/Structural Construction, HNF-SD-SNF-SAR-002, Rev. 1, Numatec Hanford Corporation for Fluor Daniel Hanford, Inc, Richland, Washington.

Gerber, M. S., 1992, Past Practices Technical Characterization Study - 300 Area - Hanford Site, WHC-MR-0388, Westinghouse Hanford Company, Richland, Washington.

Gibson, K. D., 1995, Transuranic Waste Storage and Assay Facility Interim Safety Basis, WHCSD-WM-ISB-004, Rev. 0, Westinghouse Hanford Company, Richland, Washington.

Gibson, K. D., 1996, Transuranic Waste Storage and Assay Facility Interim Safety Basis, WHC-SD-WM-ISB-004, Westinghouse Hanford Company, Richland, Washington.

Graves, C. E., 1994, D\&D Facility Acceptance Criteria for 309 Building, WHC-SD-FL-DB-002, Westinghouse Hanford Company, Richland, Washington

Griffin, G. B., 1998, Fast Flux Test Facility Standby Plan, HNF-SD-FF-SSP-056, prepared by B\&W Hanford Company for Fluor Daniel Hanford, Inc., Richland, Washington.

GSA, 1987, Federal Property Management Regulations, Temporary Regulation D-71, "Quality Workplace Environment," General Services Administration, Washington, D.C.

GSA, 1996, Federal Property Management Regulations, Part 101-25, "General," General Services Administration, Washington, D.C.

Guttenberg, S., 1995, Hanford Site Sodium Management Plan, WHC-SD-FF-MP-001, Rev. 1, Westinghouse Hanford Company, Richland, Washington. 
DOE/RL-97-55

Revision 0

Hamilton, W. H., 1995, Solid Waste Disposal Standards and Requirements Identification Document (S/RID), WHC-IP-1120, Rev. 4, Westinghouse Hanford Company, Richland, Washington.

Hanlon, B. M., 1997, Waste Tank Summary Report for Month Ending July 31, 1997, HNF-EP-0182-112, prepared by Lockheed Martin Hanford Corporation for Fluor Daniel Hanford, Inc., Richland, Washington.

Hazardous and Solid Waste Amendments of 1984, 42 USC 6901, et seq.

Highway Research Board, 1965, Highway Capacity Manual, National Academy of Sciences, National Research Council, Washington, D.C.

Himes, D. A., 1996, Radiological Consequences of a Postulated Fire in the 309 Building, WHC-SD-NEL-HIE-002, Rev. 0, Westinghouse Hanford Company, Richland, Washington.

Hisaw, B. M., 1996, Fast Flux Test Facility Standards Requirements Identification Document, WHC-SD-MP-SRID-006, Rev. 0, Westinghouse Hanford Company, Richland, Washington.

Holmes, J. J., 1994, System Engineering Functions and Requirements for the Hanford Cleanup Mission: First Issue, WHC-EP-0722, Westinghouse Hanford Company, Richland, Washington.

Hulvey, R. R., 1996, Fast Flux Test Facility (FFTF) Stabilization Project Plan, WHC-SD-FF-SSP-004, Rev. 3, Westinghouse Hanford Company, Richland, Washington.

Hyatt, J. E., 1996, Hanford Analytical Services Quality Requirements Document, DOE/RL-96-68, U.S. Department of Energy, Richland Operations Office, Richland, Washington.

Johnson, H. E., 1993, T Plant Safety Analysis Report, WHC-SD-CP-SAR-007, Rev. 1, Westinghouse Hanford Company, Richland, Washington.

Joyce, J. P., 1994, Final Safety Analysis for Contact-Handled TRU Waste Drums In-Situ Inspection and Vented Drum Retrieval, WHC-SD-WM-SAR-058, Rev. 0, Westinghouse Hanford Company, Richland, Washington.

Joyce, S. M., 1996, Hanford Analytical Sample Projections, WHC-SD-WM-TI-608, Rev. 3, Westinghouse Hanford Company, Richland, Washington.

Kelly, D. L, 1996, Test and Evaluation Document for DOT Specification $7 A$ Type A Packaging, WHC-EP-0558, Westinghouse Hanford Company, Richland, Washington. 
DOE/RL-97-55

Revision 0

Kirkbride, R. A., G. K. Allen, P. J. Certa, A. F. Manuel, R. M. Orme, L. W. Shelton, E. J. Slaathaug, R. S. Wittman (NHC), G. T. MacLean, and D. L. Penwell (SESC), 1997, Tank Waste Remediation System Operation and Utilization Plan, HNF-SD-WM-SP-012, Rev. 0, Vol. I and II, prepared by Numatec Hanford Corporation for Fluor Daniel Hanford, Inc., Richland, Washington.

Koerner, J. A., 1995, Hazard Categorization Report for the 200 Area Effluent Treatment Facility, WHC-SD-C018H-HC-002, Rev. 1, Westinghouse Hanford Company, Richland, Washington.

Kruger, O. L., 1994, Waste Receiving and Processing, Module 2A, Feed Specification, WHC-SD-W100-RD-001, Rev. 1, Westinghouse Hanford Company, Richland, Washington.

Lorenz, B. D., 1997, Multicanister Overpack Topical Report, HNF-SD-SNF-SARR-005, Rev. 0, DE\&S Hanford, Inc., for Fluor Daniel Hanford, Inc., Richland, Washington.

Luke, S. N., 1996, The 300 Area Waste Acid Treatment System (WATS) Closure Plan, DOE/RL-90-11, Rev. 1, U.S. Department of Energy, Richland Operations Office, Richland, Washington.

Lund, D. P., 1995a, FFTF Plant Transition Mission Analysis Report, WHC-SD-FF-MAR-001, Rev. 0, Westinghouse Hanford Company, Richland, Washington.

Lund, D. P., 1995b, B Plant Mission Analysis Report, WHC-SD-WM-MAR-006, Rev. 0, Westinghouse Hanford Company, Richland, Washington.

Lund, D. P., 1995c, Waste Encapsulation and Storage Facility Mission Analysis Report, WHC-SD-WM-MAR-007, Rev. 0, Westinghouse Hanford Company, Richland, Washington.

Lund, D. P., 1995d, PUREX Plant Deactivation Mission Analysis Report, WHC-SD-CP-MAR-002, Rev. 0, Westinghouse Hanford Company, Richland, Washington.

Lund, D. P., 1995e, 309 Building Deactivation Mission Analysis Report, WHC-SD-SP-MAR-001, Rev. 0, Westinghouse Hanford Company, Richland, Washington.

Lund, D. P., 1995f, 308 Building Deactivation Mission Analysis Report, WHC-SD-FL-MAR-001, Rev. 0, Westinghouse Hanford Company, Richland, Washington.

Lund, D. P., 1995g, 300 Area Fuel Supply Facilities Deactivation Mission Analysis Report, WHC-SD-FL-MAR-002, Rev. 0, Westinghouse Hanford Company, Richland, Washington. 
DOE/RL-97-55

Revision 0

Lund, D. P., 1995h, 308 Building Deactivation Function Analysis Report, WHC-SD-FL-FAR-001, Rev. 0, Westinghouse Hanford Company, Richland, Washington.

Lund, D. P., 1995i, 309 Building Deactivation Function Analysis Report, WHC-SD-SP-FAR-001, Rev. 0, Westinghouse Hanford Company, Richland, Washington.

Lund, D. P., 1995j, 300 Area Fuel Supply Facilities Deactivation Function Analysis Report, WHC-SD-FL-FAR-002, Rev. 0, Westinghouse Hanford Company, Richland, Washington.

Lund, D. P., 1995k, FFTF Plant Transition Function Analysis Report, WHC-SD-FF-FAR-001, Rev. 0, Westinghouse Hanford Company, Richland, Washington.

Lund, D. P., 19951, B Plant Function Analysis Report, WHC-SD-WM-FAR-001, Rev. 0, Westinghouse Hanford Company, Richland, Washington.

Lund, D. P., 1995m, WESF Function Analysis Report, WHC-SD-WM-FAR-002, Rev, 0, Westinghouse Hanford Company, Richland, Washington.

Lund, D. P., 1995n, PFP Transition Project Function Analysis Report, WHC-SD-CP-FAR-001, Rev. 0, Westinghouse Hanford Company, Richland, Washington.

Lund, D. P., 1995o, PUREX Plant Deactivation Function Analysis Report, WHC-SD-CP-FAR-002, Rev. 0, Westinghouse Hanford Company, Richland, Washington.

Lund, D. P., 1996, Mission Analysis Report: Deactivation Facilities at Hanford, WHC-SD-CP-MAR-003, Rev. 0, Westinghouse Hanford Company, Richland, Washington.

Maddox, B. S., 1996, Standards/Requirements Identification Document for PFP, WHC-SD-MP-SRID-003, Rev. 0, Westinghouse Hanford Company, Richland, Washington.

Mayancsik, B. A., 1994, Functional Design Criteria Waste Receiving and Processing (WRAP) Facility Module 1, WHC-SD-FDC-W026-001, Rev. 2, Westinghouse Hanford Company, Richland, Washington.

McCormack, R. L., 1997, DNFSB Recommendation 94-1 Hanford Site Integrated Stabilization Management Plan, HNF-EP-0853, Rev. 5, Fluor Daniel Hanford, Inc., Richland, Washington.

McCullough, K. S., 1994, Final Safety Analysis Report for the Waste Sampling and Characterization Facility, Rev. 0, Westinghouse Hanford Company, Richland, Washington.

Meichle, R. H., 1996, K Basins Safety Analysis Report, WHC-SD-WM-SAR-062, Rev. 3, Westinghouse Hanford Company, Richland, Washington. 
DOE/RL-97-55

Revision 0

Meloy, R. T., 1996, Waste Sampling and Characterization Facility Complex Safety Analysis, WHC-SD-WM-ASA-001, Rev. 0, Westinghouse Hanford Company, Richland, Washington.

Metcalf, I. L., 1996, Shutdown Plan for the 300 Area Fuel Supply Facilities, WHC-SD-FL-SSP-002, Rev. 2, Westinghouse Hanford Company, Richland, Washington.

Meyer, M., 1997, Interim Safety Basis for Solid Waste Facilities (T Plant), WHC-SD-WM-ISB-006, Rev. 0, Rust Federal Services of Hanford, Inc., for Fluor Daniel Hanford, Inc., Richland, Washington.

Millikin, R. M., 1998, 324/327 Buildings Stabilization/Deactivation Project, Project Management Plan, HNF-IP-1289, Rev. 1, prepared by B\&W Hanford Company for Fluor Daniel Hanford, Inc., Richland, Washington.

Mulkey, C. H., 1996, Double-Shell Tank System Waste Analysis Plan, WHC-SD-WM-EV-053, Rev, 4, Westinghouse Hanford Company, Richland, Washington.

National Environmental Policy Act of 1969, 42 USC 4321, et seq.

Nelson, D. W., 1996, PRF Deactivation Summary Plan, WHC-SD-CP-SP-001, Rev. 0, Westinghouse Hanford Company, Richland, Washington.

NFPA, 1991, Life Safety Code, NFPA 101-1991, National Fire Protection Agency, Quincy, Massachusetts.

Olander, A. R., 1995, Hanford 300 Area Treated Effluent Disposal Facility Inventory at Risk Calculations and Safety Analysis, WHC-SD-WM-SAD-025, Rev. 3, Westinghouse Hanford Company, Richland, Washington.

Pennington, L. D., 1996, Recommendation 93-5 Implementation Plan - February 1996 - Draft, DOE/RL-94-1, Rev. 1, U.S. Department of Energy, Richland Operations Office, Richland, Washington.

Place, P. G., 1991, Assessment of High Temperature Thermal Treatment Alternatives for Inclusion Into the Scope of the Hanford WRAP Facility, WHC-SD-WM-ES-198, Westinghouse Hanford Company, Richland, Washington.

Place, P. G., 1992, Thermal Treatment of Hanford's RMW - Summary Discussion of Vendor Capabilities, Internal Memorandum, Westinghouse Hanford Company, Richland, Washington.

Place, P. G., 1993, Hanford Site-Specific Engineering Study for the $W-242$ Thermal Treatment Facility, WHC-SD-W242-ES-001, Westinghouse Hanford Company, Richland, Washington. 
DOE/RL-97-55

Revision 0

PNL, 1995a, 324 Building Safety Analysis Report, PNL-SAR-324, Pacific Northwest

Laboratory, Richland, Washington.

PNL, 1995b, 327 Building Safety Analysis Report, PNL-SAR-327, Pacific Northwest

Laboratory, Richland, Washington.

PNL, 1996a, 325 Safety Analysis Report for 325 Building, PNL-SAR-325, Pacific Northwest

Laboratory, Richland, Washington.

PNL, 1996b, 325 Building Operating Limits, PNL-LIM-325, Pacific Northwest Laboratory,

Richland, Washington.

Pollution Prevention Act of 1990, 42 USC 13101, et seq.

Powell, R. W., 1998, Tank Waste Remediation System Program Plan, HNF-1883, Rev. 1, prepared by Lockheed Martin Hanford Corporation for Fluor Daniel Hanford, Inc., Richland, Washington.

Price-Anderson Amendments Act of 1988, 42 USC 2010, et seq.

Public Law 101-510, National Defense Authorization Act for Fiscal Year 1991, November 5, 1990, 104 Stat. 1485, Section 3137, "Safety Measures for Waste Tanks at Hanford Nuclear Reservation."

Ramaize, J. R, 1996, End Point Criteria for Fuel Supply Shutdown Facilities, WHC-SD-NR-DB-004, Rev. 0, Westinghouse Hanford Company, Richland, Washington.

RCW 43.20.050, "Onsite Disposal of Solid and Liquid Wastes Act," Revised Code of Washington.

Reidel, S. P., 1993, Groundwater Monitoring Plan for the Proposed State Approved Land Disposal Structure, WHC-SD-C018H-PLN-004, Rev. 0, Westinghouse Hanford Company, Richland, Washington.

Resource Conservation and Recovery Act of 1976, 42 USC 6901, et seq.

RL, 1994, Environmental Assessment - Waste Tank Safety Program, Hanford Site, Richland, Washington, DOE/EA-0915, U.S. Department of Energy, Richland Operations Office, Richland, Washington.

RL, 1995a, The Hanford Facility Dangerous Waste Permit Application T Plant Complex, DOE/RL-95-36, Rev. 0, U.S. Department of Energy, Richland Operations Office, Richland, Washington. 
RL, 1995b, Direct Disposal Team Report - Options for Treating and Disposing of Current and Future Mixed Waste Streams on the Hanford Facility, DOE/RL-95-35, U.S. Department of Energy, Richland Operations Office, Richland, Washington.

RL, 1995c, Plan and Schedule for Disposition and Regulatory Compliance for Miscellaneous Streams, DOE/RL-93-94, Rev. 1, U.S. Department of Energy, Richland Operations Office, Richland, Washington.

RL, 1996a, TWRS Privatization Contract with British Nuclear Fuels, Ltd., DE-AC0696RL13308, U.S. Department of Energy, Richland Operations Office, Richland, Washington.

RL, 1996b, TWRS Privatization Contract with Lockheed Martin Advanced Environmental Systems, DE-AC6-96RL13309, U.S. Department of Energy, Richland Operations Office, Richland, Washington.

RL, 1996c, Hanford Strategic Plan, DOE/RL-96-92, Rev. O, U.S. Department of Energy, Richland Operations Office, Richland, Washington.

RL, 1996d, TWRS Privatization Request for Proposals, DE-RP06-96RL13308, U.S. Department of Energy, Richland Operations Office, Richland, Washington.

RL, 1997a, Hanford Site Waste Minimization and Pollution Prevention Awareness Program Plan, DOE/RL-91-31, U.S. Department of Energy, Richland Operations Office, Richland, Washington.

RL, 1997b, Hanford Facility Dangerous Waste Permit for LERF/ETF, DOE/RL-97-03,

U.S. Department of Energy, Richland Operations Office, Richland, Washington.

RL, 1997c, Hanford Site Radiological Control Mamual, DOE/RL-96-109, U.S. Department of Energy, Richland Operations Office, Richland, Washington.

RL and Ecology, 1995, Safe Interim Storage of Hanford Tank Waste Final Environmental Impact Statement (SIS EIS), DOE/EIS-0212, U.S. Department of Energy, Richland Operations Office, and Washington State Department of Ecology, Richland, Washington.

Safe Drinking Water Act of 1974, 42 USC 300f, et seq.

SAIC, 1992, Treatment of Hanford's Mixed Waste Streams by INEL's Thermal Treatment Facilities, Contract No. MLW-SVV-073750, Task S-92-21, Science Applications International Corporation, Richland, Washington.

SAIC, 1993, Treatment of Hanford RMW Streams by INEL's Waste Experimental Reduction Facility (WERF) Incinerator, Contract No. MLW-SVV-073750, Task S-93-28, Science Applications International Corporation, Richland, Washington. 
DOE/RL-97-55

Revision 0

Sandoz, D. H., 1997, SNF Canister Storage Building/Hot Conditioning System Standards/Requirements Identification Document, HNF-SD-SNF-RD-007, Rev. 0, DE\&S Hanford, Inc., for Fluor Daniel Hanford, Inc., Richland, Washington.

Sellers, E. D., 1995, Implementation of the K Basins Spent Nuclear Fuel Project (SNFP) Regulatory Policy (Letter No. 95-SFD-167 to President, Westinghouse Hanford Company, September 12), U.S. Department of Energy, Richland Operations Office, Richland, Washington.

Sellers, E. D., 1996, Memorandum of Understanding (Between SFD, TPD, and RPD), "Transition of Management Responsibility for the 100-K Basins Facilities" (Letter No. 96-SFD-238 to H. J. Hatch, Subject: DE-AC-96RL13200 - Memorandum of Understanding (MOU) for Transition of Management Responsibility for the 100-K Basins Facilities, Fluor Daniel Hanford, Inc., October 7), U.S. Department of Energy, Richland Operations Office, Richland, Washington.

Sellers, E. D., and T. K. Teynor, 1996, Memorandum of Understanding (Between SFD and WPD), "Disposition and Transport of Excess Water from 100-K Basins to the 200 Area Effluent Treatment Facility, " August 15, U.S. Department of Energy, Richland Operations Office, Richland, Washington.

Sepahur, J. B., 1996, B Plant Fire Hazard Analysis, HNF-SD-WM-FHA-021, Rev. 0, Westinghouse Hanford Company, Richland, Washington.

Shapley, J. E., 1995, Plutonium Finishing Plant Final Safety Analysis Report, WHC-SD-CP-SAR-021, Rev. 0, 2 Vols., Westinghouse Hanford Company, Richland, Washington.

Smyth, W. W., 1996, Safety Analysis Report for Packaging (On-Site) Double-Shell Tank Car, WHC-SD-TP-SARP-015, Rev. 0-A, Westinghouse Hanford Company, Richland, Washington.

State Environmental Policy Act of 1971, RCW 43.21C, as amended.

Stefanski, L. D., 1997, 1996, B Plant End Point Document, WHC-SD-WM-TPP-054, Rev. 1A, Westinghouse Hanford Company, Richland, Washington.

Stordeur, R. T., 1997, 340 Waste Handling Facility Interim Safety Basis (ISB), WHC-SD-WM-ISB-003, Rev. 1A, Westinghouse Hanford Company, Richland, Washington.

Szempruch, R. W., 1994, Plutonium Finishing Plant Operational Safety Requirements, WHC-SD-CP-OSR-010, Rev. 0, Westinghouse Hanford Company, Richland, Washington.

Toxic Substances Control Act of 1976, 15 USC 2601, et seq. 
DOE/RL-97-55

Revision 0

Van Leuven, D. B., and C. B. Mattsson, 1997, Waste Management Project Fiscal Year 1998 Multi-Year Work Plan, WBS 1.2, Rev. 1, Waste Management Federal Services of Hanford, Inc., for Fluor Daniel Hanford, Inc., Richland, Washington.

Vieth, D. L., 1996a, DOE Regulatory Process for Radiological, Nuclear, and Process Safety for TWRS Privatization Contractors, DOE/RL-96-03, Rev. 0, U.S. Department of Energy, Richland Operations Office, Richland, Washington.

Vieth, D. L., 1996b, Guide to Establishing a Set of Essential Radiological, Nuclear, and Process Safety Standards and Requirements for TWRS Privatization, DOE/RL-96-04, Rev. 0, U.S. Department of Energy, Richland Operations Office, Richland, Washington.

Vieth, D. L., 1996c, Concept of the DOE Regulatory Process for Radiological, Nuclear, and Process Safety for TWRS Privatization Contractors, DOE/RL-96-05, Rev. 0, U.S. Department of Energy, Richland Operations Office, Richland, Washington.

Vieth, D. L., 1996d, Top-Level Radiological, Nuclear, and Process Safety Standards and Principles for TWRS Privatization Contractors, DOE/RL-96-06, Rev. 0, U.S. Department of Energy, Richland Operations Office, Richland, Washington.

WAC 173-160, "Minimum Standards for Construction and Maintenance of Wells," Washington Administrative Code, as amended.

WAC 173-200, "Water Quality Standards for Ground Waters of the State of Washington," Washington Administrative Code, as amended.

WAC 173-201A, "Water Quality Standards for Surface Waters of the State of Washington," Washington Administrative Code, as amended.

WAC 173-216, "State Waste Discharge Permit Program," Washington Administrative Code, as amended.

WAC 173-221, "Discharge Standards and Effluent Limitations for Domestic Wastewater Facilities," Washington Administrative Code, as amended.

WAC 173-240, "Submission of Plans and Reports for Construction of Wastewater Facilities," Washington Administrative Code, as amended.

WAC 173-303, "Dangerous Waste Regulations," Washington Administrative Code, as amended

WAC 173-304, "Minimum Functional Standards for Solid Waste Handling," Washington Administrative Code, as amended.

WAC 173-307, "Plans," Washington Administrative Code, as amended. 
DOE/RL-97-55

Revision 0

WAC 173-400-141, "Prevention of Significant Deterioration," Washington Administrative Code, as amended.

WAC 246-247, "Radiation Protection--Air Emissions," Washington Administrative Code, as amended.

WAC 246-272, "On-Site Sewage Systems," Washington Administrative Code, as amended.

WAC 246-290, "Public Water Supplies," Washington Administrative Code, as amended.

WAC 248-54, "Rules and Regulations of the State Board of Health Regarding Public Water Systems," Washington Administrative Code, as amended.

WAC 248-54-175, "Maximum Contaminant Levels (MCL)," Washington Administrative Code, as amended.

Wagoner, J. D., 1996a, Contract Number DE-AC06-96RL13200, Approval of K Basins Safety Analysis Report, WHC-SD-WM-SAR-062, Rev. 3, and K Basins Technical Safety Requirements (Letter No. 96-SFD-264 to H. J. Hatch and N. H. Williams, Fluor Daniel Hanford, Inc., October 16), U.S. Department of Energy, Richland Operations Office, Richland, Washington.

Wagoner, J. D., 1996b, WHC Indirects - Workscope Reductions Approved by RL (Letter No. 9600367B to A. L. Trego, Westinghouse Hanford Company, February 12), U.S. Department of Energy, Richland Operations Office, Richland, Washington.

Wagoner, J. D., 1997, Acceptance of K Basin Sludge Storage and Disposal Recommendation (Letter No. 97-SFD-149 to H. J. Hatch, Fluor Daniel Hanford, Inc., August 1), U.S. Department of Energy, Richland Operations Office, Richland, Washington.

Watson, D. J., 1995, SNF K Basins Standards/Requirements Identification Document, WHC-SD-SNF-RD-001, Rev. 0, Westinghouse Hanford Company, Richland, Washington.

Weaver, L. L., 1996, 222-S Laboratory Interim Safety Basis, WHC-SD-CP-ISB-002, Rev. 1, Westinghouse Hanford Company, Richland, Washington.

Weidert, J. R., 1997, Final Safety Analysis Report for Waste Receiving and Processing Facility, HNF-SD-W026-SAR-002, Rev. 0, Waste Management Federal Services of Hanford, Inc., for Fluor Daniel Hanford Company, Richland, Washington.

WHC, 1994, Fuel Supply Facilities Shutdown Plan, Westinghouse Hanford Company, Richland, Washington.

WHC, 1996a, Life-Cycle Cost Estimate for the B Plant Transition Project, WHC-SD-HT-PCE-002, Westinghouse Hanford Company, Richland, Washington. 
WHC, 1996b, Life-Cycle Cost Estimate for the WESF Project, WHC-SD-HT-PCE-004, Westinghouse Hanford Company, Richland, Washington.

WHC-CM-1-10, Safety Manual, Westinghouse Hanford Company, Richland, Washington.

WHC-CM-7-5, Environmental Compliance, Westinghouse Hanford Company, Richland, Washington.

Willis, N. P., 1993, Hanford Site Solid Waste Acceptance Criteria, WHC-EP-0063, Rev. 4, Westinghouse Hanford Company, Richland, Washington.

WSDOT, 1982, Guidelines for Functional Classification, Washington State Department of Transportation, Olympia, Washington.

WSDOT, 1984, Standard Specifications for Road/Bridge/Municipal Construction, Washington State Department of Transportation, Olympia, Washington.

WSDOT, 1986, Design Manual, M22-01, Washington State Department of Transportation, Olympia, Washington. 
DOE/RL-97-55

Revision 0

\section{DISTRIBUTION}

Number of Copies

ONSITE

1

U.S. Department of Energy

Richland Operations Office

Public Reading Room

$\mathrm{H} 2-53$

1

Lockheed Martin Hanford Corporation

M. L. Grygiel

H8-71

3

Lockheed Martin Services, Inc.

S. R. Nelson

H6-31

Central Files

B1-07

Document Processing Center

A3-93

1

Pacific Northwest National Laboratory

Hanford Technical Library

P8-55

Dist-I 
DOE/RL-97-55

Revision 0

This page intentionally left blank.

Dist-2 